\title{
The epidermal growth factor receptor (EGFR) : family members as targets to improve the radiosensitivity of human malignant solid tumors
}

Citation for published version (APA):

Lammering, G. (2004). The epidermal growth factor receptor (EGFR) : family members as targets to improve the radiosensitivity of human malignant solid tumors. [Doctoral Thesis, Maastricht University]. Universiteit Maastricht. https://doi.org/10.26481/dis.20041202gl

Document status and date:

Published: 01/01/2004

DOI:

10.26481/dis.20041202gl

Document Version:

Publisher's PDF, also known as Version of record

Please check the document version of this publication:

- A submitted manuscript is the version of the article upon submission and before peer-review. There can be important differences between the submitted version and the official published version of record.

People interested in the research are advised to contact the author for the final version of the publication, or visit the DOI to the publisher's website.

- The final author version and the galley proof are versions of the publication after peer review.

- The final published version features the final layout of the paper including the volume, issue and page numbers.

Link to publication

\footnotetext{
General rights rights.

- You may freely distribute the URL identifying the publication in the public portal. please follow below link for the End User Agreement:

www.umlib.nl/taverne-license

Take down policy

If you believe that this document breaches copyright please contact us at:

repository@maastrichtuniversity.nl

providing details and we will investigate your claim.
}

Copyright and moral rights for the publications made accessible in the public portal are retained by the authors and/or other copyright owners and it is a condition of accessing publications that users recognise and abide by the legal requirements associated with these

- Users may download and print one copy of any publication from the public portal for the purpose of private study or research.

- You may not further distribute the material or use it for any profit-making activity or commercial gain

If the publication is distributed under the terms of Article $25 \mathrm{fa}$ of the Dutch Copyright Act, indicated by the "Taverne" license above, 
The Epidermal Growth Factor Receptor (EGFR)- Family Members as Targets to Improve the Radiosensitivity of Human Malignant Solid Tumors

Guido Lammering 
Printed by: Universal Press, Veenendaal

ISBN: 90-9018699-9

Copyright: Chapter 1

Chapter 2

Chapter 3

Chapter 4

Chapter 5,6
Guido Lammering, 2004

Nature Publishing Group 2001;

Elsevier Science Inc. 2001

American Association. of Cancer Research 2001;

Taylor and Francis Health Sciences, 2003;

Oxford University Press 2001

Nature Publishing Group 2003;

American Association of Cancer Research, 2004

Guido Lammering, 2004

All rights reserved. No parts of this publication may be reproduced, stored in a retrieval system, or transmitted in any form or by any means, electronically, mechanically, by photocopying or otherwise, without the prior written permission of the author and the editors. 


\title{
The Epidermal Growth Factor Receptor (EGFR)- Family Members as Targets to Improve the Radiosensitivity of Human Malignant Solid Tumors
}

\section{Proefschrift}

\author{
ter verkrijging van de graad van doctor \\ aan de Universiteit Maastricht, \\ op gezag van de Rector Magnificus, \\ Prof. mr. G.P.M.F. Mols \\ volgens het besluit van het College van Decanen, \\ in het openbaar te verdedigen \\ op donderdag 2 december 2004 om 16.00 uur precies
}

door

Guido Lammering 


\section{Promotor}

Prof. dr. P. Lambin

\section{Copromotor}

Dr. B. Wouters

\section{Beoordelingscommissie}

Prof. dr. F. Ramaekers (voorzitter)

Prof. dr. M. Baumann (University of Dresden, Germany)

Prof. dr. D. Kieback

Prof. dr. A.J. van der Kogel (Radboud Universiteit Nijmegen)

Prof. dr. H. Schouten 
Aan Judith,

Tobias en David 
The animal-based research was performed in accordance with current regulations and standards of the U.S. Department of Agriculture, Washington, DC, the U.S. Department of Health and Human Services, Washington, DC, and the National Institutes of Health, Bethesda, MD (USA).

The investigations have been carried out at the Molecular Radiobiology Laboratories of the Department of Radiation Oncology, Medical College of Virginia, Virginia Commonwealth University, Richmond, Virginia, USA; they were supported by Public Health Sevice grants PolCA72955, the R01CA65896 (to R. Schmidt-Ullrich), the R01CA88906 ( to Paul Dent) from the National Cancer Institute, National Institutes of Health, Department of Health and Human Services, by the Florence and Hyman Meyers Head and Neck Cancer Research Fund (to R. Schmidt-Ullrich), by Grant DAMD17-99-1-9426 (to Paul Dent), and by the Deutsche Krebshilfe, Dr. Mildred Scheel Stiftung fellowship support (to G. Lammering). 


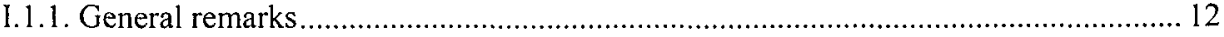

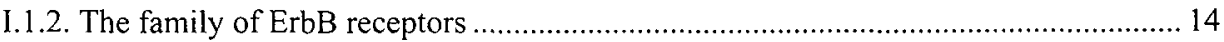

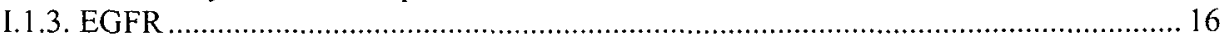

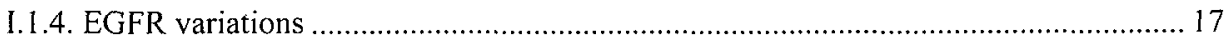

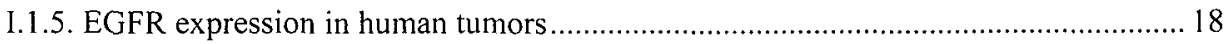

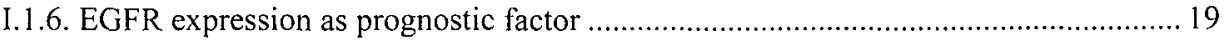

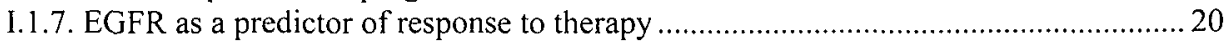

I.1.8. Potential therapeutic approaches to inhibit EGFR and their relative efficiency ........ 21

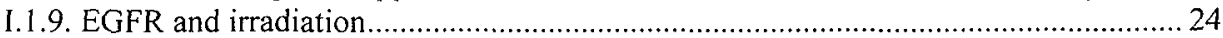

1.1.10. Background based conclusions and outline of the principal investigations: ............26

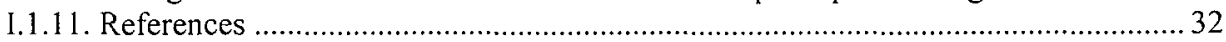

Chapter II

Mechanistical in vitro studies on the role of ErbB1-4 in cellular radiation responses

II.1. The relative role of ErbB 1-4 receptor tyrosine kinases in radiation signal transduction responses of human carcinoma cells.....

G Bowers, D Reardon, T Hewitt, P Dent, R B Mikkelsen, K Valerie, G Lammering,

C Amir and R K Schmidt-Ullrich. Oncogene. 20, 1388-1397, 2001

II.2. Adenovirus- mediated overexpression of dominant negative epidermal growth factor receptor- CD533 as a gene therapeutic approach radiosensitizes human carcinoma and malignant glioma cells

Guido Lammering, Peck-Sun Lin, Joseph N. Contessa, Jaime L. Hampton,

Kristoffer Valerie and Rupert K. Schmidt-Ullrich. Int J Rad Biol Phys. 51: 775-784, 2001

Chapter III 80

\section{Preclinical in vivo studies using dominant-negative EGFR to radiosensitize malignant glioma and human carcinoma}

III.1. Radiosensitization of malignant glioma cells through over-expression of dominantnegative EGFR

Guido Lammering, Kristoffer Valerie, Peck-Sun Lin, Ross B. Mikkelsen, Joseph N. Contessa,

Jeffrey P. Feden, Julie Farnsworth, Paul Dent and Rupert K. Schmidt-Ullrich. Clin Cancer Res. 7: 682-690, 2001

III.2. An anti-erbB receptor strategy as gene therapeutic intervention to improve radiotherapy in malignant human tumours 
III.3. Epidermal growth factor receptor as a genetic therapy target for carcinoma cell radiosensitization

Guido Lammering, Theodore H. Hewit, William T. Hawkins, Joseph N. Contessa, Dean B. Reardon,

Peck-Sun Lin, Kristoffer Valerie, Paul Dent, Ross B. Mikkelsen, Rupert K. Schmidt-Ullrich

J Natl Cancer Inst. 93: 921-9, 2001

Chapter IV

The role of EGFRvIII in cellular radiation responses

IV.1. EGFRvIII-mediated radioresistance through a strong cytoprotective response

Guido Lammering, Theodore H. Hewit, Kristoffer Valerie, Joseph N. Contessa, George P. Amorino,

Paul Dent, Rupert K. Schmidt-Ullrich. Oncogene. 22: 5545-5553, 2003

IV.2. Inhibition of the EGFRVIII mutant receptor by dominant-negative EGFR-CD533

enhances malignant glioma cell radiosensitivity

Guido Lammering, Theodore H. Hewit, Kristoffer Valerie, William Hawkins, Peck-Sun Lin,

Ross B. Mikkelsen, Rupert K. Schmidt-Ullrich. Clin. Cancer Res., 2004, in press

Chapter V

Summary, general discussion and future perspectives

V.1. Summary.....

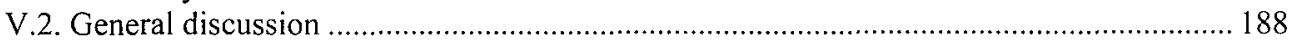

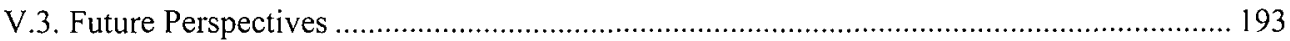

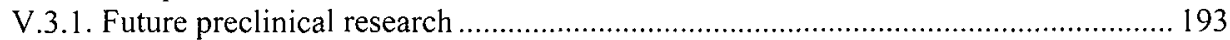

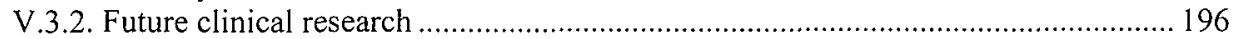

Chapter VI ................................................................................................201

\section{Samenvatting, CV en lijst van publicaties}

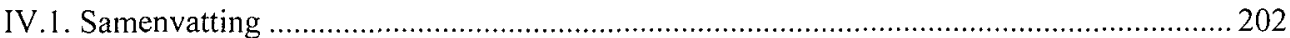

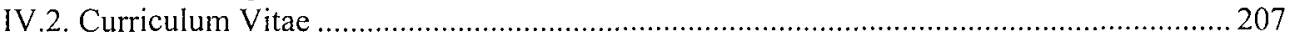

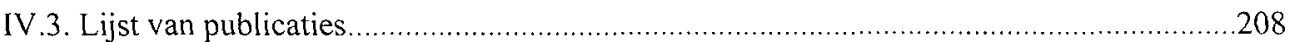

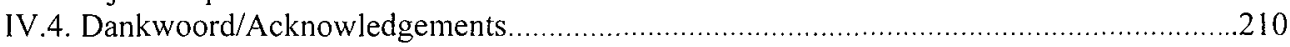


Explanations for abbreviations and symbols (if used more than once)

Ad

Ad-EGFR-CD533

Ad-LacZ

$\beta$-gal

$\mathrm{C}$

C225

CA

$\mathrm{CHO}$

CHO.EGFRwt

CHO.EGFRvIII

CHO.mock

D

$D_{37}$

DER

DN

Dox

EGF

EGFRwt

EGFR

EGFR-CD533

EGFRvIII

FBS

GF

Gy

IR

JNK 1

$\mathrm{mAb}$

MAPK

MBP

MCC

Min

mock-

MOI adenovirus

adenovirus expressing EGFR-CD533

adenovirus expressing lac $Z$

$\beta$-galactosidase

control

monoclonal antibody against EGFR

carcinoma

Chinese hamster ovary celline

$\mathrm{CHO}$ cells transiently expressing EGFRwt

CHO cells transiently expressing EGFRvIII

$\mathrm{CHO}$ cells, mock transfected

mean inactivation dose

radiation dose for a cell survival of $37 \%$

dose enhancement ratio

dominant negative

doxycycline

epidermal growth factor

EGFR wild-type

epidermal growth factor-receptor

dominant- negative EGFR

natural variant of EGFR

fetal bovine serum

growth factor

gray

ionizing radiation

c-jun NH2-terminal kinase

monoclonal antibody

mitogen activated protein kinase

myelin basis protein

mammarian carcinoma cells

minutes

mock treatment

multiplicity of infection 
NSCLC

NS

$\mathrm{P}$

PCR

Pfu

PI3K

$\mathrm{PKC}$

PKB

PLC $\gamma$

$\operatorname{Rad}$

RTK

SCC

SD

SDS

SEM

Tyr

Tyr-P non-small cell lung cancer

non significant

p-value

polymerase-chain-reaction

plaque forming unit

phosphatidylinositol 3-kinase

protein kinase $\mathrm{C}$

protein kinase $\mathrm{B}$

phospholipase $\gamma$

radiation

receptor tyrosine kinase

squamous carcinoma cells

standard deviation

sodium-dodecyl-sulfate

standard error of the mean

tyrosine

tyrosine phosphorylation 
Chapter I

General Introduction 


\section{I.1. General Introduction and research outline}

\section{I.1.1. General remarks}

After a quarter century of rapid advances, cancer research has generated a rich and complex body of knowledge, revealing cancer to be a disease involving dynamic changes in the genome. Observations of human cancers and animal models argue that tumor development proceeds via a process, in which a succession of genetic changes, each conferring one or another type of growth advantage, leads to the progressive conversion of normal human cells into cancer cells. $(1,2)$. Hanahan and Weinberg have suggested that cancer is a manifestation of six essential alterations in cell physiology that collectively dictate malignant growth, the so called six hallmarks of cancer: self-sufficiency in growth signals, evasion of programmed cell death (apoptosis), limitless replicative potential, sustained angiogenesis, and tissue invasion and metastasis. Each of these physiological changes -novel capabilities acquired during tumor development- represents the successful breaching of an anticancer defence mechanism hardwired into cells and tissues (3).

The key role that growth factors and their receptors play in the development and progression of human cancers can be highlighted by use of the six hallmarks of cancer described (3). Tumor cells can proliferate in the absence of stimulatory signals, generating many of their own growth signals, thereby reducing their dependence on stimulation from their normal tissue microenvironment. This acquired growth signal autonomy represents the first of the six capabilities to be clearly related to growth factors and their receptors, like the epidermal growth factor receptor (EGFR) family of receptors, which are often upregulated in several tumor types (Figure 1). Ligand- independent signalling can also be achieved through structural alteration of receptors (4).

The ability of tumor cell populations to expand in number is determined not only by the rate of cell proliferation but also by the rate of cell attrition, represented by programmed cell death - apoptosis. The apoptotic machinery is divided into two components - sensors and effectors. Cancer cells through a variety of strategies can acquire resistance to apoptosis. Surely, the most commonly occurring loss of a pro- apoptotic regulator through mutation involves the p53 tumor suppressor gene. Additionally, the PI3 kinase- Akt/PKB pathway, which transmits antiapoptotic survival signals, is likely involved in mitigating apoptosis in a substantial fraction of human tumors. This survival signal can be activated through growth factors and their receptors, like the IGF-I/2 and IGF-1R (5), but also the EGFR family of receptors (6), thereby promoting the second hallmark of cancer (Figure 1). It is expected that virtually all cancer cells harbour alterations that enable evasion of apoptosis. 
In order to progress to a larger size, incipient neoplasias must develop angiogenic ability $(7,8)$. Counterbalancing positive and negative signals encourage or block angiogenesis. One class of these signals is conveyed by soluble factors and their receptors. The angiogenesis- initiating signals are exemplified by vascular endothelial growth vector (VEGF), acidic and basic fibroblast growth factors (FGF1/2) and the receptors VEGFR1 and VEGFR2. These angiogenesis- initiating signals

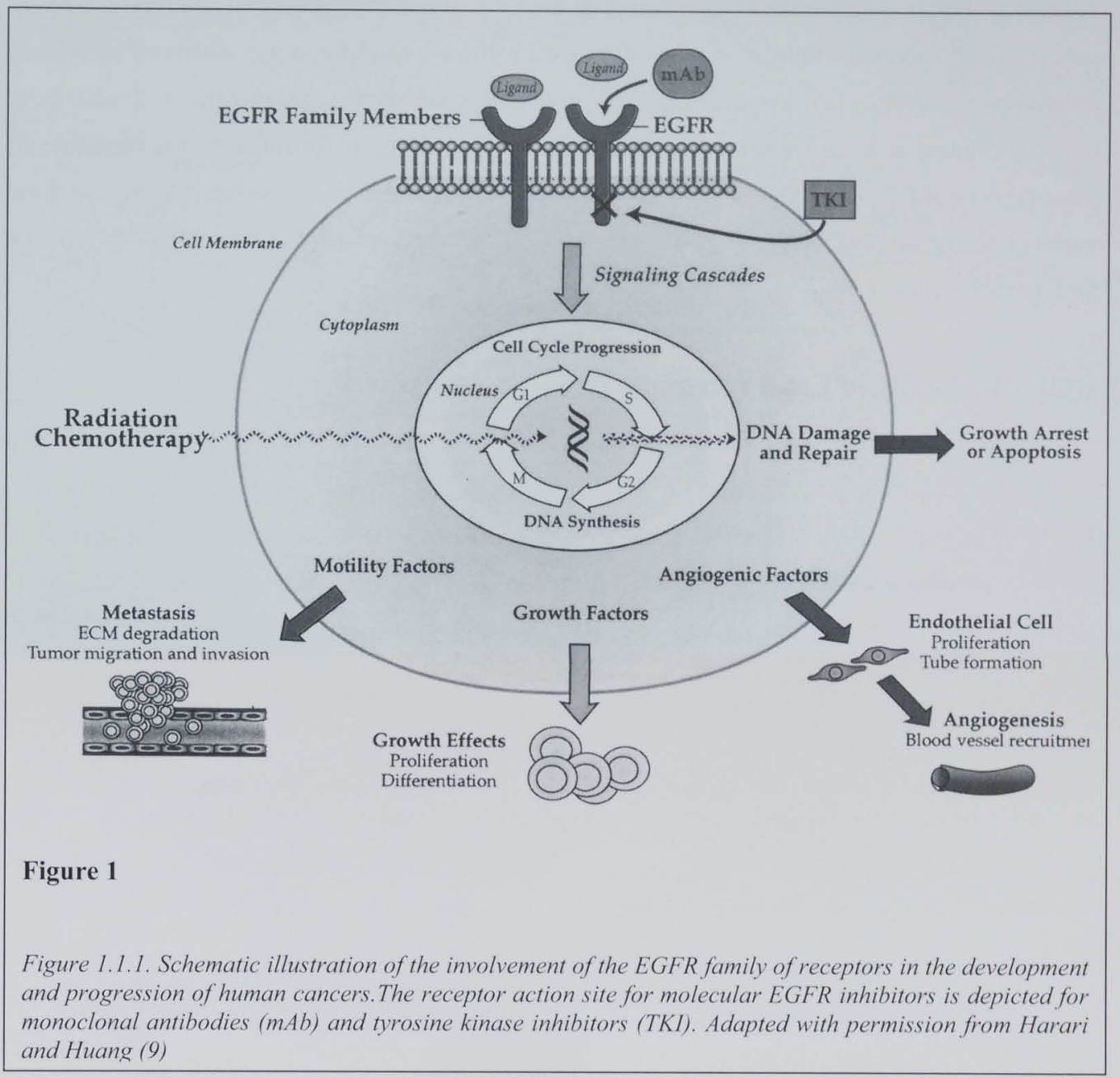

are also expressed through EGFR family dependent signalling transductions, thus indicating the additional involvement of the EGFR family in the fourth hallmark of cancer (Figure 1).

The capability for invasion and metastasis enables cancer cells to escape the primary tumor mass and colonize new terrain in the body where, at least initially, nutrients and space are not limiting. 
Several classes of proteins involved in the tethering of cells to their surroundings in a tissue are altered in cells processing invasive or metastatic capabilities. E-cadherin serves as a widely acting suppressor of invasion and metastasis by epithelial cancers, and its functional elimination represents a key step in the acquisition of this capability. More and more evidence also gives growth factors and their receptors evident roles in this sixth hallmark capability through increased expression of pro-invasive motility factors responsible for migration and invasion (Figure $1 ; 9$ )

Taken together, growth factors or their receptors are overexpressed or aberrantly expressed in many cancers. Such abnormal stimulation of growth factor pathways results in unregulated cell signalling, contributing to dysregulation of growth, tumor initiation or promotion, and invasion and metastasis, thus contributing to at least 4 of the 6 hallmarks of cancer. The degree to which tumors capitalize on these cell signalling pathways is also illustrated by the large number of oncogenes related to cellular genes encoding growth factors (e.g., sis, hst), growth factor receptors (kit,trk,erbB-2) or tyrosine kinases (abl,src,lck) (10).

\section{I.1.2. The family of ErbB receptors}




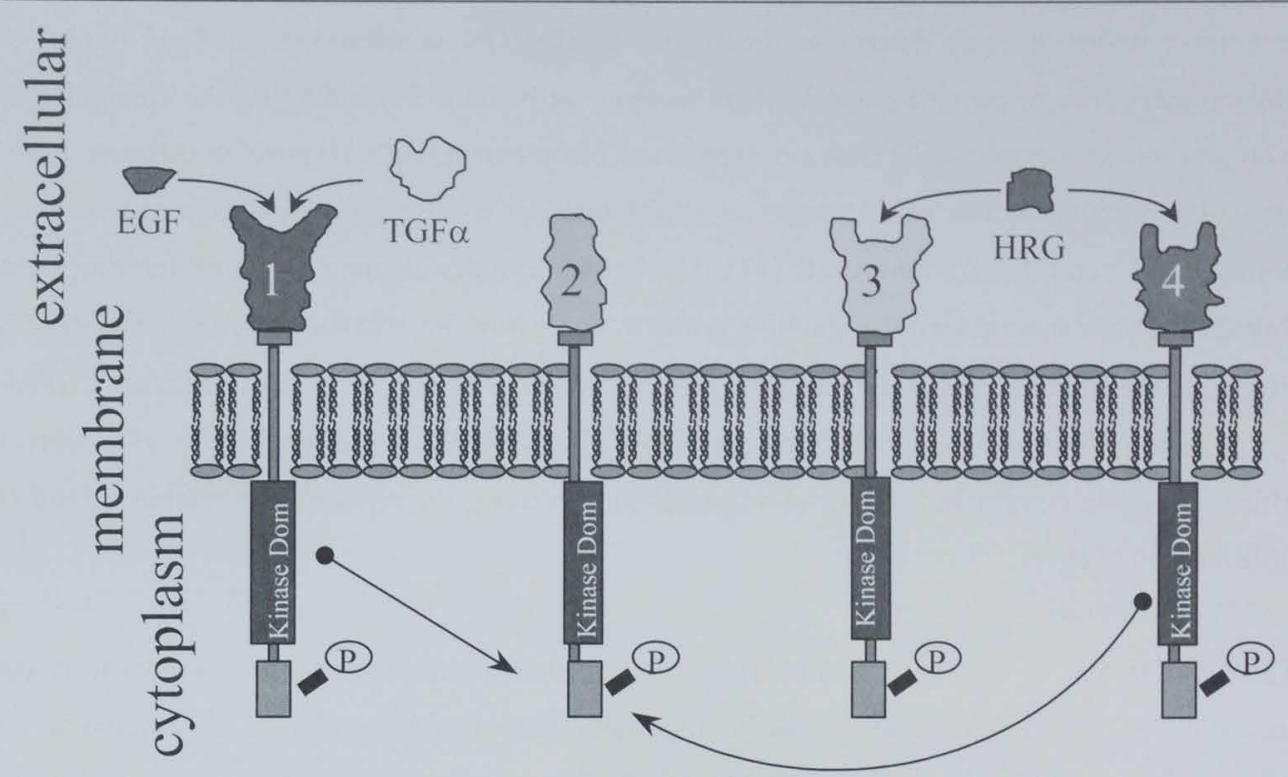

Figure 2

Figure 1.1.2. Schematic illustration of the 4 members of the ErbB receptor Tyr kinase family, ErbB 1-4, also named the EGFR family of receptors. Kinase Dom, Kinase domain; EGF, epidermal growth factor; $H R G$, heregulin; $T G F-\alpha$, transforming growth factor- $\alpha$

Members of the ErbB receptor Tyr kinase (RTK) family, ErbB1-4, are intimately involved in the growth control of mammalian cells (Figure 2). In normal cells they become activated by growth factor through paracrine and juxtacrine mechanisms. As one of the important steps in neoplastic progression, ErbB receptor Tyr kinases in carcinoma cells become part of an autocrine growthregulatory circuit also involving the ErbB- specific growth factor- ligands such as epidermal growth factor (EGF), transforming growth factor- $\alpha$ (TGF- $\alpha$ ) or heregulin (HRG) (11). Although the plasma membrane- components share important similarities as $170-200 \mathrm{kD}$ transmembrane glycoproteins, each ErbB species carries a specific function within the ErbB-receptor Tyr kinase response network (12-17). ErbB 1 (EGFR) and ErbB4 are complete receptors with growth factor binding sites in the extracellular $\mathrm{NH} 2$-portion and a Tyr kinase domain in the cytoplasmic $\mathrm{COOH}-$ terminal portion of the molecule. The latter also contains some Tyr residues critical for the activation of ErbB receptor tyrosine kinases after homo- or heterodimerization as a response to growth- factor binding (18-21). ErbB 2 represents a constitutively active receptor without a ligand binding domain, and ErbB3 shares ligand specificities with ErbB4 but lacks Tyr kinase activity. 
Therefore, ErbB2 and ErbB3 represent important modulators of cellular response to growth factors through heterodimerization with ErbB 1 and ErbB 4 (12-21). These different properties of ErbB receptor tyrosine kinases determine the nature of their interactions with defined homo- and heterodimerization hierarchies and result in receptor activation. Depending on the carcinoma cell type and its ErbB receptor Tyr kinase expression complement, cells respond to different growth factor ligands that induce proliferation responses through a hierarchy of primary and secondary homo- and heterodimerization events (13). The ErbB receptors mediate their proliferative signals through a major cytoprotective signalling pathway involving the adaptor proteins (i.e., GrB2 and SHC), GTP exchange factors such as SOS, phospholipase $\mathrm{C} \gamma$ (PLC $\gamma$ ), Ras, protein kinase C (PKC), Raf, MAPK, and PI-3-Kinase dependent pathways. These signalling pathways directly or indirectly affect cell cycle control and transcription regulation initiating the biosynthetic machinery and cell proliferation (22).

The ErbB family of receptor tyrosine kinases and related plasma membrane receptors have been identified as critical components facilitating autocrine growth regulation of carcinoma and malignant glioma cells that are typically the result of coordinated co- expression of growth factors and their receptors. (23-26). The activation of receptor tyrosine kinases and stimulation of downstream signalling pathways that mediate mitogenesis have been defined as the underlying mechanism. Within the ErbB family ErbB-1 (EGFR) and ErbB-2 (Her-2/neu) are currently the bestknown and understood members to date.

\section{I.1.3. EGFR}

The epidermal growth factor receptor (EGFR) is a 1,186- amino acid, 170- kilodalton transmembrane protein, comprised of an extracellular ligand-binding domain, a transmembrane lipophilic segment, and a cytoplasmic protein tyrosine kinase domain. A variety of ligands for the EGFR have been identified. These include epidermal growth factor (EGF), transforming growth factor, amphiregulin, and heparin-binding EGF. The most commonly expressed ligand for the EGFR in human tissues is TGF- $\alpha$. After ligand binding, the EGFR undergoes dimerization. Dimerization thereby activates the intrinsic protein kinase via intermolecular autophosphorylation within the cytoplasmic domain. The phosphorylated tyrosine residues function as binding sites for cytoplasmic messenger proteins, which then initiate a cascade of signals from the cytoplasm to the nucleus, eventually prompting mitogenesis, tumor cell growth and cell survival. $(22,26,27)$.

All cells of epithelial origin as well as many cells from mesenchymal derivation express the EGFR.

A primary function of the EGFR revolves around its capacity to influence cellular growth, 
proliferation, and differentiation. In recent years, many reports have confirmed an overexpression of EGFR in epithelial tumors. As in the case with other growth factor receptors, increased EGFR activation can result from higher levels of ligand (such as EGF), EGFR gene amplification, increased transcription, or mutations that cause unregulated receptor signalling. In many cancers this excessive EGFR activation has been shown to stimulate tumor growth. Preclinical studies indicate that EGFR- mediated signalling may also affect other aspects of tumor progression including angiogenesis, cell survival, and metastasis. In human cancers, such phenotypic changes appear to be critical for disease progression and patient survival. The EGFR is expressed on the cell surface on many normal tissues, and elevated numbers of these receptors have been detected on a variety of human tumors including breast, lung, head and neck squamous cell carcinomas, glioblastoma multiforme, and colorectal carcinomas. (28-34). Indeed, a correlation between EGFR overexpression and disease stage, disease progression, patient survival, and response to therapy has been put forth for a variety of the most common human malignancies (35). Several studies have demonstrated that overexpression of EGFR in various tumor types is associated with a poor patient prognosis. $(31,36-38)$.

Although this correlation between EGFR overexpression and poor clinical outcome appears convincing, a direct cause and effect relationship has yet to be firmly established. It is certainly possible that a simple arithmetic quantification of EGFR may not be as important as the specific reliance of a particular cell type or tissue on the EGFR pathway for growth

\section{I.1.4. EGFR variations}

Overexpression of epidermal growth factor receptor (EGFR) in autocrine growth-regulated carcinoma and malignant glioma cells is associated with the expression of mutated EGFR species as part of neoplastic progression (39-43). One mutant EGFR, named EGFRvIII lacks a portion of the extracellular ligand-binding domain due to genomic deletions that eliminate exons 2 to 7 resulting in 801 cDNA nucleotides (cDNA nucleotides 275 - 1075) (40). This deletion eliminates amino acids 6 - 273 of the extracellular subdomain I and II and the cystein-rich EGF- ligand-binding site $(43,44)$, leading to a constant active tyrosine kinase (Figure 3 ). Therefore, it can cause ligandindependent transformation of cell lines $(45,46)$. EGFRvIll is not found in normal tissues but is expressed on the cell membrane in certain tumors including $50 \%$ of all gliomas, in many prostate cancers, and in subsets of breast, non-small cell lung and ovarian cancers. $(39,41)$.

Mechanistical studies to elucidate the unique functions of EGFRvlll have been limited by the fact that the receptor is only expressed in vivo and is rapidly down regulated in vitro (47). Therefore, 
most studies concentrated on the transformation activity and the effects on downstream signal transduction $(40,48,49)$. However, the role of EGFRvIII in cellular responses to genotoxic stresses,

Wild type
EGFR
Inhibitory domain
Figure 3
Figure I.I.3 Schematic illustration of the structural differences between the wild- type EGFR and the
variant EGFR III. TK, tyrosine kinase

such as ionising radiation or other cytotoxic cancer therapeutic agents, has been only minimally investigated and has therefore been analysed in the studies presented herein.

\section{I.1.5. EGFR expression in human tumors}

EGFR is expressed on normal cells at levels ranging from 20.000 to 200.000 receptors per cell. However, receptor levels can be much higher in malignant cells. MDA-468 breast cancer cells, which have an amplified EGFR gene and overexpress the receptor protein, may have up to 2 million surface EGF receptors per cell. Tumor cells in culture are usually less dependent on exogenous growth factors for proliferation and survival than normal cells. This is presumably due to autocrine stimulation of the receptor by production of EGF or TGF- $\alpha$ from the tumor cells, which completes the feedback loop by binding to its own receptors. In support of this hypothesis, coexpression of EGFR and TGF- $\alpha$ was observed in nearly $40 \%$ of lung tumors (50). Studies of the MDA-468 breast cancer cell line have detected production of a TGF- $\alpha$ - like factor that is secreted into the medium and can compete with EGF binding to EGFR. Tumor cells therefore may not require increased expression of EGFR for continued survival, just a functional autocrine loop. The levels of EGFR expression and activity vary widely with the tumor type, due in part to differences in detection 
methods. The range of EGFR overexpression observed for a given tumor type among different studies, and for various types of tumors, is illustrated in table 1. Despite the variable expression seen among studies with respect to percentages and absolute protein levels, there is substantial evidence for increased EGFR expression in multiple tumor types.

Table 1: EGFR- overexpression in selected human solid tumors

\begin{tabular}{llcc}
\hline Tumor Type & $\begin{array}{l}\text { Percentage of Tumors } \\
\text { Expressing EGFR } \\
\text { (Range) }\end{array}$ & $\begin{array}{c}\text { Expression in } \\
\text { Corresponding } \\
\text { Normal Tissue }\end{array}$ & References \\
& & + & \\
\hline \hline NSCLC & $40-80 \%$ & + & $30,51,52$ \\
Renal Carcinoma & $50-90 \%$ & + & 30,53 \\
Breast & $14-91 \%$ & $31 \%$ & $28,29,54,55$ \\
Ovarian & $35-70 \%$ & - & $30,36,56$ \\
Glioma & $40-50 \%$ & + & $30,32,57$ \\
Pancreatic & $30-50 \%$ & + & 30,31 \\
Head and Neck & $80-100 \%$ & only in & 30,34 \\
Colon & $25-77 \%$ & basal epithelium & 30,59 \\
Bladder & $31-48 \%$ & & \\
& & & \\
\hline \hline
\end{tabular}

Data from studies suggest that in animal models EGFR expression may be greater in tumor metastases compared to the primary tumor. Increased EGFR expression was found in metastases, but not in the primary tumors, in nude mice xenograft of A431 epidermoid carcinoma (60). In tumor cells isolated from human colon carcinoma biopsies, highly metastatic cells had EGFR mRNA levels that were more than fivefold greater than low metastatic cells (61).

\section{I.1.6. EGFR expression as prognostic factor}

In light of the frequent overexpression of EGFR in tumors and preclinical data supporting the role of EGFR in tumor progression, numerous studies have been conducted to determine if EGFR expression can serve as a prognostic factor in patients with cancer. There is considerable debate in the literature over the value of EGFR as a prognostic indicator. In some studies EGFR expression has been associated with increased risk of recurrence, reduced survival, advanced tumor stage, and increased risk of metastasis. (36-38,56). For example, patients with head and neck cancer, the EGFR level may be useful for predicting tumor recurrence and appears to be superior to other prognostic indicators for this disease. Grandis and colleagues found that in addition to EGFR, TGF$\alpha$ tumor expression was also a prognostic factor in head and neck cancer, and the expression level 
of both markers correlated with disease-free survival $(31,62)$. Expression of EGFR, TGF- $\alpha$, and EGF is also correlated with risk of recurrence in bladder cancer $(59,63)$. A significant correlation between EGFR expression in tumors and a shorter time to disease recurrence and / or survival was observed in ovarian, laryngeal, squamous cell lung, and node- positive breast cancer. In ovarian cancer, patients with high EGFR expression were more likely to have tumor recurrence (56). Table 2 gives an overview of the to date published data regarding the prognostic significance of EGFR.

Table 2: Prognostic Significance of EGFR in Selected Human Carcinomas

Tumor Type Observations

univariate (u) Ref.

multivariate $(\mathbf{m})$

\begin{tabular}{|c|c|c|c|}
\hline \multirow[t]{3}{*}{ NSCLC } & Correlated with shorter overall survival & $\mathrm{u}, \mathrm{m}$ & 37,64 \\
\hline & Correlated with poor prognosis, & $\mathrm{u}$ & 65 \\
\hline & Correlated with high metastatic rate & $\mathrm{u}$ & 66 \\
\hline \multirow[t]{5}{*}{ Breast } & Correlated with worse overall survival & & \\
\hline & and relapse- free survival for short follow- up (1-4 years) & $\mathrm{u}$ & 28 \\
\hline & Correlation not significant at 10 -year follow up & $\mathrm{u}, \mathrm{m}$ & 67 \\
\hline & Negatively correlated with ER/PR status & u & 28 \\
\hline & EGFR and ErbB2 were correlated with prognosis & $\mathrm{u}, \mathrm{m}$ & 68 \\
\hline \multirow[t]{3}{*}{ Ovarian } & Correlation with poor prognosis & u & 36 \\
\hline & Correlation with poor overall and disease-free survival & u & 56 \\
\hline & EGFR- association with resistance to chemotherapy & u & 69 \\
\hline \multirow[t]{2}{*}{ Glioma } & Correlated with differentiation & u & 57 \\
\hline & EGFR amplification correlated with prognosis & $\mathrm{u}, \mathrm{m}$ & 70 \\
\hline Pancreatic & $\begin{array}{l}\text { Coexpression of EGFR with EGF/TGF- } \alpha \text { associated } \\
\text { with advanced stage, tumor size, and decreased survival }\end{array}$ & $\mathrm{u}$ & 71 \\
\hline \multirow[t]{3}{*}{ Head and Neck } & EGFR significant predictor of disease-free survival & $\mathrm{u}, \mathrm{m}$ & 62 \\
\hline & Correlated with overall survival in laryngeal carcinoma & $\mathrm{u}, \mathrm{m}$ & 38 \\
\hline & $\begin{array}{l}\text { Correlated with poor prognosis in advanced stage of } \\
\text { nasopharyngeal carcinoma }\end{array}$ & $\mathrm{u}, \mathrm{m}$ & 72,73 \\
\hline Colon & Correlated with poorer prognosis & $\mathrm{u}, \mathrm{m}$ & 74,75 \\
\hline Rectum & Correlated with reduced survival & $\mathrm{u}, \mathrm{m}$ & 76 \\
\hline \multirow[t]{2}{*}{ Bladder } & Associated with increased risk of recurrence & $\mathrm{u}, \mathrm{m}$ & 59,63 \\
\hline & EGFR expression higher in invasive tumors & & 77 \\
\hline
\end{tabular}

\section{I.1.7. EGFR as a predictor of response to therapy}

Alterations in chemosensitivity have been noted in preclinical studies of EGFR-overexpressing tumor cell lines. Indeed, higher levels of expressing of drug-resistance-related proteins, like Topoisomerase II and p-glycoprotein are found in untreated proteins with EGFR-positive renal tumors. Ogawa and colleagues measured EGFR expression and cisplatin sensitivity in tumor tissues from 84 patients with lung cancer. EGFR expression was significantly higher in tumors that were 
resistant to cisplatin compared to cisplatin-sensitive tumors (78). Similarly, patients with ovarian cancer who have EGFR-positive tumors or increased TGF- $\alpha$ expression have a lower rate of response to chemotherapy with cisplatin compounds compared to patients with lower EGFR levels (56). Santini and colleagues reported that patients with head and neck tumors in which EGFR expression levels were $>100 \mathrm{fmol} / \mathrm{mg}$ protein had a lower probability of response to chemotherapy than did patients with EGFR levels $<100 \mathrm{fmol} / \mathrm{mg}$ protein $(79,80)$.

Furthermore, an association between EGFR expression and clinical radioresistance has been reported in patients with cancer. Maruzi and colleagues and just recently Ang and colleagues reported a correlation between EGFR overexpression and response to radiotherapy in human head and neck cancers, as well as rectal cancer $(38,81,82)$. EGFR expression was a significant and independent prognostic indicator for overall survival and recurrence -free survival after radiation therapy in patients with astrocytic gliomas (83). Recently, Pillai and colleagues noted that patients who had residual or recurrent disease after radiotherapy for cervical cancer had more EGFR expression than those patients who were disease-free (84). Other authors found an inverse correlation between EGFR expression and radiocurability in murine carcinomas (85). Treatment of EGF protected cells against radiation in culture, whereas treatment with an antibody against EGFR induced radiosensitization (86). While preclinical studies indicate that EGFR inhibition can sensitise many tumor cells to ionising radiation, in vitro sensitisation with cell lines may not reflect the prognostic implications of EGFR overexpression in vivo.

Together, the current data available suggest that higher levels of EGFR may be associated with chemo- and / or radioresistance in some tumors. These findings therefore stimulated the research of targeted modulation of EGFR function as a new therapeutic strategy. However, the current data available are insufficient to suggest using EGFR expression as a predictor for response to chemoand/ or radiotherapy. It is probably more valuable to consider modifying EGFR activity to enhance chemo- and/or radiotherapy.

\section{I.1.8. Potential therapeutic approaches to inhibit EGFR and their relative efficiency}

Recognition of the EGFR as an important regulator of tumor cell growth in the early 80's stimulated the development of strategies to inhibit EGFR signalling as anticancer agent. The rationale for EGFR as a promising target in cancer therapy is a strong link between the tyrosine kinase receptor and the initiation, growth and metastasis of many human tumors as described and the 
overexpression of EGFR by many epithelial tumors. The inhibition of EGFR function may provide a strong clinical benefit to a broad spectrum of patients with epithelial malignancies expressing EGFR. During the complex processes that occur from ligand binding through signal transduction and altered gene expression, there are many opportunities for therapeutic intervention. For reasons of clarity, only the main potential strategies for inhibiting EGFR will be further discussed.

Over the past several years, it has been recognized that antibodies, small-molecule inhibitors and gene therapeutic interventions can be used therapeutically to disturb EGFR signalling and therefore EGFR function at the cellular level. These approaches include monoclonal antibodies directed against the receptor, synthetic tyrosine kinase inhibitors that act directly on the cytoplasmic domain of EGFR and EGFR mutants gene therapeutically overexpressed to carry out dominant negative action against EGFR function.

Various groups have generated a number of antibodies directed against the EGFR. Two such antibodies, M225 and M528, were found to compete with EGF and TGF- $\alpha$ binding, inhibit EGFinduced tyrosine kinase-dependent phosphorylation, and downregulate EGFR expression by inducing receptor internalisation. Among the most promising of these murine antibodies was M225, which was subsequently chimerized to the constant region of human immunoglobin $\mathrm{G}$ to produce the chimerical monoclonal antibody 225, IMC-225 (Cetuximab®). Several studies have demonstrated the ability of this antibody to modulate tumor cell proliferation, chemo- and radiosensitivity and tumor cell growth in vivo, which is likely to be induced through interference with tumor cell angiogenesis $(87,88)$. These experiments were mainly performed with carcinoma cell lines, which are predominantly growth- regulated through EGFR. In other cell lines, like malignant glioma cell lines or breast carcinoma cell lines, cell growth could be dominantly regulated through other ErbB receptors, which would limit the broad applicability of IMC-225. The first results of a large phase III international study testing the combination of Cetuximabß to radiation therapy for patients with head and neck cancer have just been reported at the ASCO meeting 2004 (89). In this study, the median survival was nearly twice as great in the Cetuximab group demonstrating IMC-225 (Cetuximab®) to be a new promising treatment for head and neck cancer in the combination with RT.

Another important therapeutic approach to block EGFR activity has involved the use of compounds that inhibit the tyrosine kinase activity of EGFR or the ErbB receptors in general. Several classes of small- molecule tyrosine- kinase - inhibitor compounds have been developed including quinazoline, pyrazolo, pyrido, and pyrrolopyrimidines, which are the furthest forward in development. Tyrosine 
kinase inhibitors must be highly specific to be used therapeutically. The inhibitors studies to date have varying levels of specificity. They act by competitively inhibiting ATP binding. ZD1839 (Iressa $($, Astra Zeneca, Wilmington, DE) is an anilinoquinazoline with an IC50 of $20 \mathrm{nM}$ for the EGFR tyrosine kinase. It binds reversibly to EGFR tyrosine kinase. OSI-774 (Erlotinib®, formerly CP358,774) is a quinazoline analogue with a nanomolar IC50 for reversible inhibition of EGFR activity and high specificity for the receptor (90). Cl-1033 is a novel quinazoline that irreversibly inhibits EGFR and ErbB 2 tyrosine kinases. As a result, this compound seems to function as a panErbB tyrosine kinase inhibitor. Finally, PKI-166 represents a potent pyrrolopyrimidine competitively reversibly binding to the ATP binding site of EGFR and ErbB2 tyrosine kinases.

First studies suggest sensitising effects of these compounds for chemotherapeutics and irradiation. In initial clinical studies, Iressa ${ }^{\circledR}$ had minimal adverse effects (91-93), but tumour responses were observed in only 10 to 19 percent of patients with chemotherapy-refractory advanced non-small cell lung cancer (94-95). The addition of Iressa $\otimes$ to traditional chemotherapy provided no benefit (9697). Despite these discouraging results, the remarkably rapid and often profound response to Iressa $($ in a subgroup of patients with non-small cell lung cancer led to its approval as single-drug therapy for refractory lung cancer. Meanwhile, the underlying mechanisms for the dramatic responses in a subgroup of patients have been identified. Somatic mutations in the tyrosine kinase domain of the EGFR gene in patients with Iressaß- positive lung cancer are responsible for the rapid and often dramatic clinical response. These mutations lead to increased growth factor signalling and confer susceptibility to the inhibitor (98). These findings have suggested for the first time that genetic screening for such mutations in lung cancer may identify patients who will have a response to the anti-EGFR compound Iressa $($ as a single drug.

To date, there are only very few studies available trying to define the mechanisms behind the sensitisation effects. Although the pharmacological development of small- molecule tyrosinekinase - inhibitor compounds has already resulted in a new generation of compounds acting with a broader spectrum of ErbB activity, like Cl-1033, which basically functions as a pan-ErbB tyrosine kinase inhibitor, their effectivity will still be limited due to the ErbB receptor turnover compared to a genetic approach, which is presented herein. This therapeutic approach of functional inhibition of the ErbB-receptor tyrosine kinase network through gene therapeutic expression of a dominantnegative EGFR mutant called EGFR-CD533 will be described in more detail in the present thesis project. 


\section{I.1.9. EGFR and irradiation}

Over the past decade, molecular biological approaches applied to radiobiological questions have uncovered several mechanisms by which cells respond to ionising radiation $(6,26,99)$. DNA damage responses are arguably the most critical, although it is unclear if they can account for the variability in response observed between different tumors and patients. Radiation effects on protein expression and activation of cellular signalling are also important. This is demonstrated by the radiationinduced activation of signal transduction cascades initiated through events in the plasma membrane. These signalling responses in autocrine growth regulated cancer cells include plasma membrane receptor Tyr kinases, like the EGFR family, non- receptor Tyr kinases and their downstream effectors (6).

Three principal consequences of EGFR activation have been shown to be important for tumors and radiation response:

1) Proliferation and cell cycle effects: The influence of EGFR on tumor cell proliferation has been mainly established by studies investigating the capacity of anti-EGFR agents to slow tumor proliferation and modulate cell cycle phase distribution $(100,101)$.

2) Anti-apoptosis and survival: EGF has been demonstrated in some cell lines to prevent apoptosis or promote survival in cells that overexpress EGFR (102). Many studies on inhibition of EGFR stimulation suggest that activation of growth factor receptors like EGFR may have a role in promoting cell survival in some tumors (102-104).

3) Angiogenesis: Several oncogenic growth factors and their receptors, including EGF and EGFR, are thought to play a role in tumor angiogenesis as evidenced by numerous studies (105). EGFR activation has been shown to upregulate VEGF production, whereas EGFR inhibition significantly effects tumor angiogenesis and reduces VEGF expression (88).

The exact mechanisms by which the EGFR family pathway mediates resistance to radiation have been investigated in radiobiological studies over the last years. It has been shown that irradiation of mammalian cells with clinically relevant doses can activate existing cellular signal transduction pathways. These signalling transduction pathways, which mainly include protein kinases, induce cytoprotective and cytotoxic responses from cell survival to cell death. Cytoprotective responses include signalling cascades of the mitogen activated proteinkinase (MAPK) and the phosphatidylinositol-3 phosphatkinase (PI3K), which activate the biosynthetic cascade and therefore possibly 
stimulate cell proliferation. Previous work has shown that EGFR and the ErbB receptor tyrosine kinases play an important role in these radiation- induced cellular signalling transduction responses (106-109). An EGFR-dependence has been found for the radiation- induced activation of phospholipase $\mathrm{C}_{\gamma}$ (PLC $\gamma$ ), the MAPK cascade as well as the radiation- induced proliferation response, which has been described for normal as well as neoplastic squamous cells (110). Taken together, the radiation- induced cytoprotective responses of cells might potentially be induced at the level of the cell membrane through activation of the ErbB receptor tyrosine kinases and other involved molecules (Figure 4). Therefore, it seems possible that the blockade of receptor function could result in radiosensitization in tumor cells. 
Radiation- induced activation

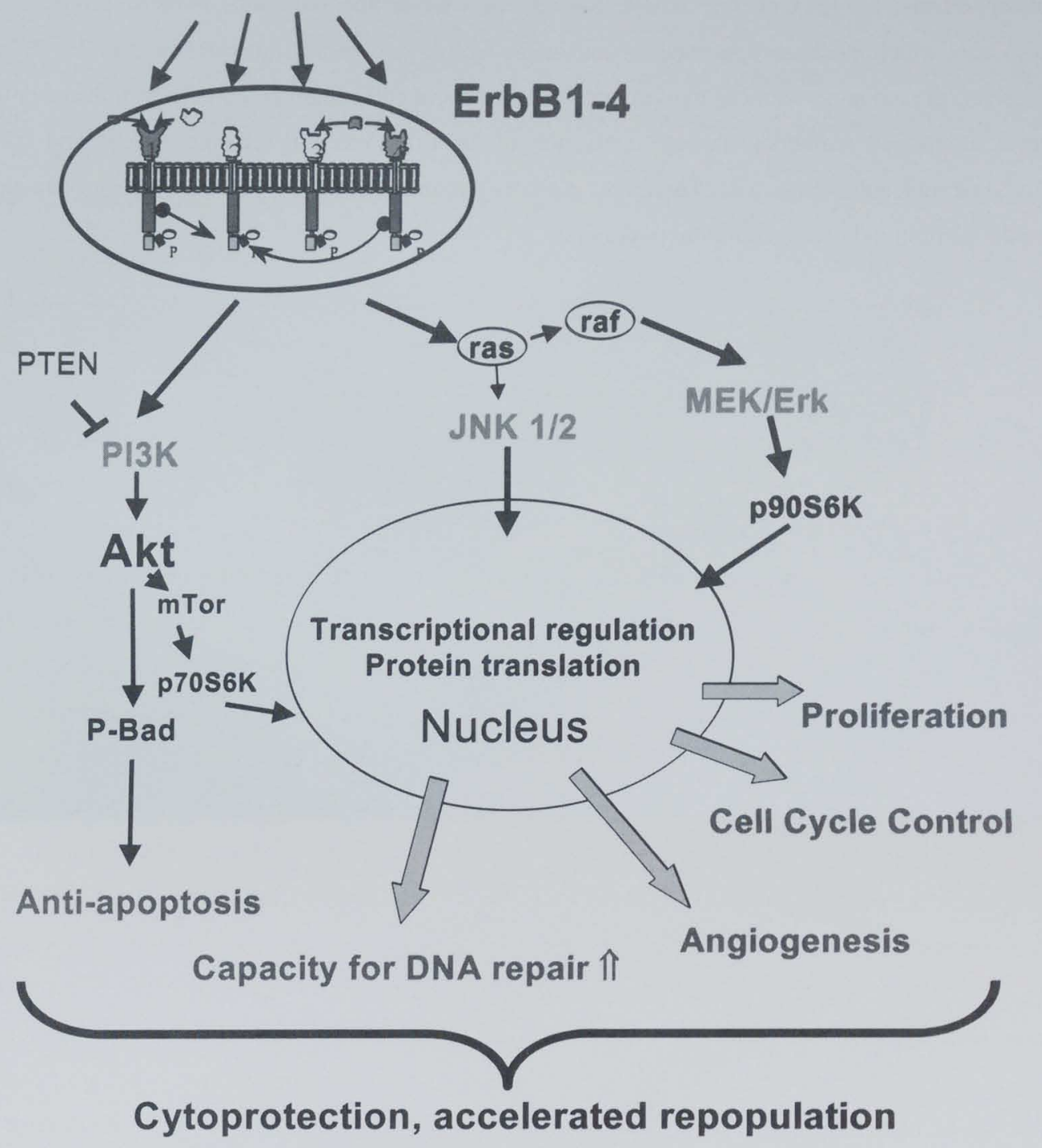

Figure 4

Figure I.1.4 Schematic illustration of the radiation-induced EGFR family-mediated pro-proliferative and cytoprotective responses to ionizing radiation. 


\section{I.1.10. Background based conclusions and outline of the principal investigations:}

EGFR and the other ErbB receptor tyrosine kinases are critically involved in the autocrine growth regulation of many carcinoma and malignant glioma cells $(11,12,57,111)$. Previous studies have demonstrated that treatment of tumor cells with ionising radiation at clinically relevant doses of 1 to 5 Gy induces immediate activation of $\operatorname{EGFR}(90,112,113)$. In addition, repeated radiation exposures of 2 Gy leads to increased EGFR expression (114). The radiation- induced activation of EGFR is defined by a several-fold increase in tyrosine phosphorylation currently indistinguishable from the effects of growth factor $(26,84,113,115,116)$. In addition, radiation- induced EGFR activation results in a dose-dependent proliferative response both after single (115) and repeated radiation exposures $(109,112)$. On the basis of these findings, it has been concluded that radiation -induced EGFR activation contributes, at least in part, to the mechanism of accelerated repopulation $(22,26,107,117)$. The accelerated proliferation or repopulation after repeated radiation exposures represents a response of acute reacting normal tissue and tumors. Evidence for accelerated proliferation stems from experimental data on mouse skin (110). Many similar studies have been conducted on acute reacting, rapidly turning over normal tissues demonstrating similar regeneration cell kinetics $(117,118)$. The recognition that accelerated proliferation may counteract the effectiveness of fractionated irradiation employed in clinical radiotherapy is derived from retrospective radiobiological analyses for clinical experiences and has been confirmed in prospective randomised studies. Tumor control data for squamous cell carcinomas (SCC) of the head and neck treated with a spectrum of fractionation schedules over varied treatment times demonstrated an inverse relationship between overall treatment time and tumor control probability. Assuming certain tumor response parameters, a linear relationship was evident between treatment time and tumor control probability during the first 4 weeks of radiotherapy. However, after the 4 th week, a break point occurred, demonstrating a steeper response slope indicative of an increasing rate of treatment failures with extension of treatment time (117). This finding was interpreted as dominance of the accelerated proliferation response of tumor clonogens occurring during the latter part of the radiotherapy course of head and neck SCC (119). Although the concept of accelerated proliferation as a potential source for increased radiotherapy failures has found broad acceptance the start point and the mechanisms of this proliferation response during repeated radiation exposures remains controversial because some analyses suggest initiation of the proliferation response at a much earlier point $(118,120)$. This concept is also supported by recent clinical investigations using shortened radiotherapy courses in the form of accelerated regimens. Institutional experiences employing accelerated superfractionation regimens and a recent randomised clinical trial comparing such schedules demonstrated $10 \%-30 \%$ superior tumor control 
and, in some instances, survival rates relative to more protracted once-daily standard radiotherapyregimens (121-123).

Recent radiobiological studies are elucidating the molecular mechanisms of radiation- induced accelerated proliferation. These studies demonstrate the involvement of critical growth regulatory gene products in the response of autocrine growth-regulated human carcinoma cells to single and repeated doses of ionising radiation. There is increasing evidence for radiation- induced activation of pre-existing pathways critically involved in cellular proliferation control $(107,108)$.

Ionising radiation exerts growth- factor- like effects in autocrine growth regulated human carcinoma cells through the activation of pre-existing signal transduction pathways. This immediate activation of ErbB receptor tyrosine kinases in the plasma membrane, and the possible secondary events of TGF- $\alpha$ release at later times, plays a critical role in the activation of the major cytoprotective signalling cascade involving MAPK, PI-3-K, and transcriptional activation events and results in antiapoptotic and proproliferative cellular responses. Considering the correlation between radiationinduced activation of ErbB receptor tyrosine kinases and MAPK/ PI-3-K, it has been concluded that this activation represents the underlying mechanism of accelerated repopulation.

The increased biosynthetic activity of rapidly proliferating tumor cells can be expected to increase the capacity for DNA damage repair. Because the proliferative as well as the DNA repair responses of tumor cells counteract the toxic effects of radiotherapy, we have defined them as cytoprotective. The critical role of EGFR in initiating these cytoprotective responses is supported by findings that, at every level of the cytoprotective signals, the activation of downstream components is dependent upon the activation of EGFR. This applies to the activation of PLC $\gamma$ and changes in the $\mathrm{Ca}^{2+}$ ionic homeostasis, MAPK, PI3-K, the cell cycle regulator $\mathrm{p} 21^{\mathrm{CIP}-1}$, the transcription factor Elk-1, and the overall cellular proliferation response (108). Considering the special role of EGFR in initiating these cytoprotective responses following radiation, disruption of EGFR function should prevent the cytoprotective responses and therefore mediate tumor cell radiosensitization.

Therefore, the ultimate goal in the thesis project presented herein was to investigate and to test the broad therapeutic potential of inhibiting the EGFR activation after irradiation as a promising strategy to enhance the radiosensitivity for a variety of different human tumor cells.

For reasons of specificity and broad applicability we chose to inhibit EGFR through a genetic approach by overexpressing EGFR-CD533, a mutant of EGFR that lacks the entire cytoplasmic 


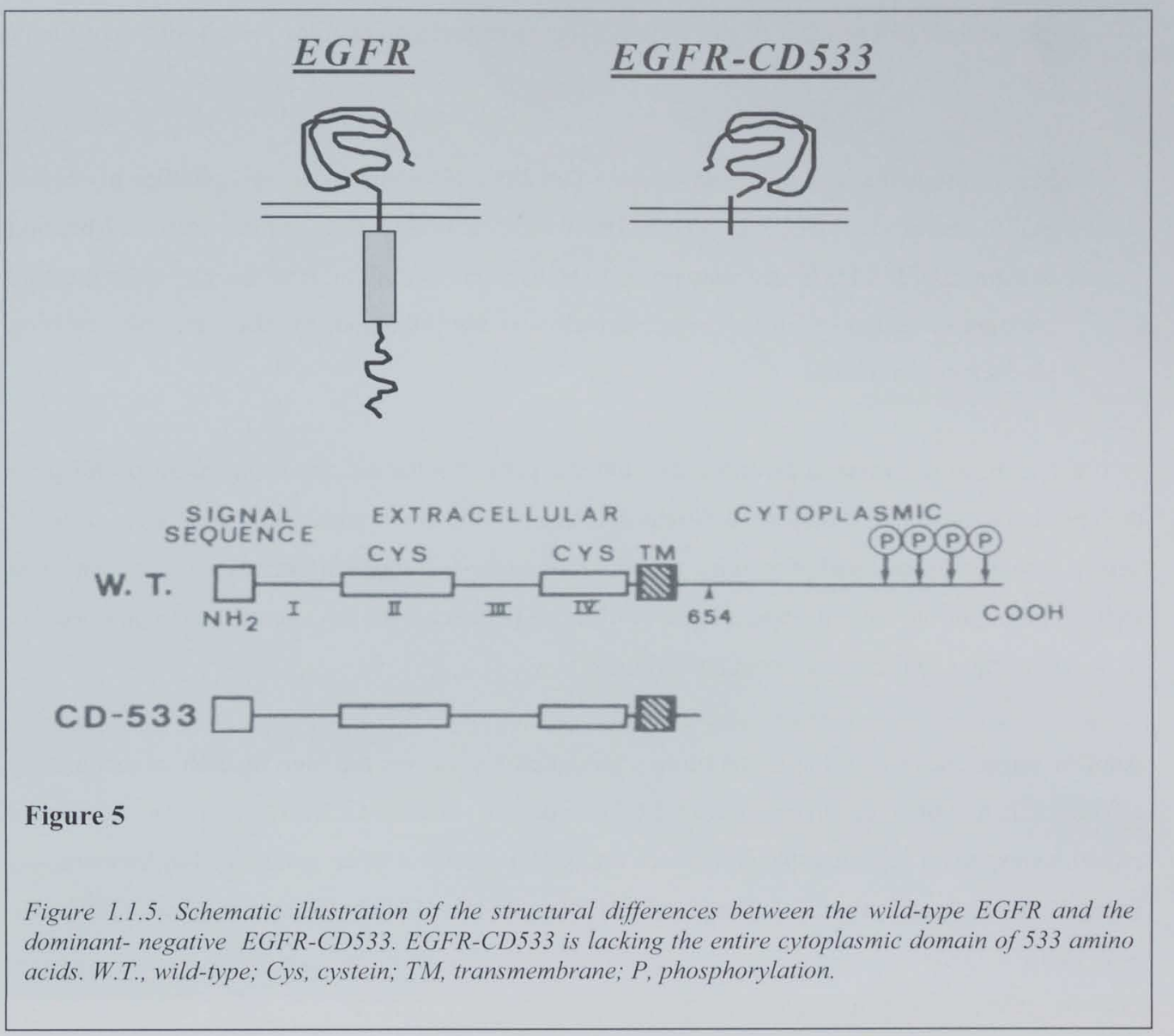

domain of 533 amino acids and confers no transformation or proliferation- promoting activity, but maintains the transmembrane location and the ability to dimerize (Figure 5). Previous investigations have demonstrated that the overexpression of EGFR-CD533 in stably transfected MDA-EGFRCD533 mammary carcinoma cells completely blocked radiation- induced activation of EGFR with secondary inhibition of MAPK activation and the radiation- induced proliferation response cytoprotective, proproliferative signalling $(26,108,109,112)$.

Based on the background knowledge we decided to investigate and test a genetic approach for two reasons:

1. Ionising radiation not only activates EGFR, but also all the other ErbB receptors expressed by a given tumor cell line. The over-expression of dominant- negative EGFR-CD533 
disrupts the entire ErbB receptor tyrosine kinase network through receptor- protein interactions independent of the varied receptor- expression profiles seen in different tumor cells.

2. Many carcinoma and malignant glioma cell lines also express a high number of mutant EGFR-species in vivo, e.g. EGFRvIII, which lacks the EGF amino- terminal-binding domain. EGFR-CD533 may also prove to be useful in disrupting responses by these mutated constitutive active EGFR species, which are not inhibited by the currently existing monoclonal antibodies.

In order to be able to test and further develop the gene therapeutic approach into a useful gene therapy approach for a variety of different cell lines in vitro and subsequently in vivo, a useful vector system was required. For this, we chose replicate-incompetent adenoviruses as the most useful vectors for our investigations, because of the experience with this vector system and because of the advantages of these vectors in later clinical use.

Another important goal of the thesis project presented herein was the investigation of modulatory effects of a naturally occurring mutant EGFR- species, called EGFRvIII on the acute cellular radiation responses and possible influences on cellular survival after radiation. Furthermore, we wanted to analyse and investigate the functional modulation of EGFRvIII through genetic inhibition with EGFR-CD533

Taken together, the thesis project presented herein is mainly based on the hypothesis that the inhibition of the radiation- induced activation of the EGFR family of receptors can improve the radiosensitivity of tumor cells independent of their varying ErbB expression profiles.

Overall, our investigations presented were guided by the following hypotheses and questions:

1. Is the gene therapeutic inhibition of the radiation- induced EGFR activation through dominant- negative EGFR-CD533 a useful strategy to enhance the radiosensitivity of a variety of different tumor cells?

2. Does the intratumoral infusion of adenoviral vectors expressing EGFR-CD533 as a gene therapeutic approach result in radiosensitization for human malignant solid tumors? 
3. Does expression of the naturally occurring variant of EGFR, called EGFRvIII modulate the acute cellular radiation responses and enhance cell survival?

4. Can adenoviral expression of EGFR-CD533 modulate or inhibit the functional consequences of EGFRvIII expression? 


\section{I.1.11. References}

1. Foulds L. The experimental study of tumor progression. London: Academic Press 1954;Volumes I-III

2. Nowell PC. The clonal evoluation of tumor cell populations. Science 1976;194:23-28.

3. Hanahan D, Weinberg RA. The hallmarks of cancer, Cell 2000;100:57-70.

4. Fedi P, Tronick SR, Aaronson SA. Growth factors. In Cancer Medicine, JF Holland, RC Bast, DL Morton, E Frei, DW Kufe, RR Weichselbaum, eds., Baltimore, MD:Williams and Wilkins, 41-64.

5. Evan G, Littlewood T. A matter of life and cell death. Science 1998,281:1317-22.

6. Schmidt-Ullrich RK, Contessa JN, Lammering G, Amorino GP. Receptor tyrosine kinases and cellular responses to ionising radiation. Oncogene Reviews 2003,22:5855-65.

7. Bouck N, stellmach V, Hsu SC. How tumors become angiogenic. Adv Cancer Res 1996,69:135-174.

8. Folkman J. Tumor angiogenesis. In Cancer Medicine, JF Holland, RC Bast, DL Morton, E Frei, DW Kufe, RR Weichselbaum, eds., Baltimore, MD:Williams and Wilkins, 181-204.

9 Harari P, Huang SM. Radiation response modification following molecular inhibition of epidermal growth factor receptor signaling. Sem Radiat Oncol 2001;11:281-89.

10. Powis G. Signalling pathways as targets for anticancer drug development. Pharmacol Ther 1994;62:57-95.

11. Chryssogelos SA, Dickson RB. EGF receptor expression, regulation, and function in breast cancer. Breast Cancer Res Treat 1994; 29:29-40.

12. Alimandi M, Romano A, Curia, MC, Muraro R, Fedi P, Aaronson SA, et al., Cooperative signaling of ErbB3 and ErbB2 in neoplastic transformation and human mammary carcinomas. Oncogene 1995;10:1813-21.

13. Gamett DC, Greene T, Wagreich AR, Kim HH, Koland JG, Cerione RA. Heregulin-stimulated signaling in rat pheochromocytoma cells. Evidence for ErbB3 interactions with Neu/ErbB2, p85. J Biol Chem 1995; 270:19022-19027.

14. Guy PM, Platko JV, Cantley LC, Cerione RA, Carraway KL III, Insect cell-expressed p180 erbB3 pocesses an impaired tyrosine kinase activity. Proc Natl Acad Sci USA 1994;91:8132-8136.

15. Riese DJ II, Stern DF. Specificity within the EGF family/ErbB receptor family signaling network. Bioessays 1998;20:41-48.

16. Segatto O, Lonardo F, Wexler D, Fazioli F, Pierce JH, Bottaro DP, White MF, Di Fiore PP. The juxtamembrane regions of the epidermal growth factor receptor and gp185 erbB2 determine the specificity of signal transduction. Mol Cell Biol 1991;11:3191;3202.

17. Zhang K, Sun J, Liu N, Wen D, Chang D, Thomason A, Yoshinaga SK. Transformation of NIH 3T3 cells by HER3 or HER4 receptors requires the presence of HER1 or HER2. J Biol Chem 1996;271:3884-3890.

18. Earp HS, Dawson TL, Li X, Yu H. Heterodimerization and functional interaction between EGF Receptor Family Members: A New Signaling Paradigm with Implications for Breast Cancer Research. Breast Cancer Res Treat 1995;35:115-132.

19. Graus-Porta D, Beerli RR, Daly JM, Hynes NE. ErbB-2, the preferred heterodimerization partner of all ErbB receptors, is a mediator of lateral signaling. EMBO 1997;16:1647-1655.

20. Gulliford TJ, Huang GC, Ouyang X Epstein RJ. Reduced ability of transforming growth factor-alpha to Induce EGF receptor heterodimerization and downregulation suggests a mechanism of oncogenic Synergy with ErbB2. Oncogene 1997;15:2219-2223.

21. Qian W, LeVea CM, Freeman JK, Dougall WC, Greene MI. Heterodimerization of EGFR and wildtype or kinase deficient Neu: a mechanism of inter-receptor kinase activation and transphosphorylation. Proc Natl Acad Sci USA 1994;91:1500-1504.

22. Schmidt-Ullrich RK, Dent P, Grant S, Mikkelsen RB, Valerie K. Signal transduction and cellular radiation responses. Radiat Res 1999;153:245-257.

23. Weinberg, RA. Oncogenes and the molecular origin of cancer. Cold Spring Harbor, NY: Cold Spring Harbor Laboratory, 1989; 54-62

24. Baselga, J, Mendelsohn, J. The epidermal growth factor receptor as a target for therapy in breast carcinoma. Breast Cancer Res Treat 1994;29:127-138.

25. Tang P, Steck PA, Yung WKA. The autocrine loop of TGF-a/EGFR and brain tumors. J Neuro-Oncol 1997;35:303-314.

26. Schmidt-Ullrich RK, Dent P, Grant S, Mikkelsen RB, Valerie K. Signal transduction and cellular radiation responses. Radiat Res 2000;153:245-257. 
27. Ullrich A, Schlessinger J. Signal transduction by receptors with tyrosine kinase activity. Cell 1990;61:203-212.

28. Klijn JG, Berns PM, Schmitz PI, Foekens JA. The clinical significance of epidermal growth factor receptor (EGF-R) in human breast cancer: a review on 5232 patients. Endocr Rev 1992;13-3-17.

29. Bucci B, D'Agnano I, Botti C, Mottolese M, Carico E, Zupi G, Vecchione A. EGF-R expression in ductal breast cancer: Proliferation and prognostic implications. Anticancer Res 1997;17:769-774.

30. Salomon DS, Brandt R, Ciardiello F, Normanno N. Epidermal growth factor-related peptides and their receptors in human malignancies. Crit Rev Oncol Hematol 1995;19:183-232.

31. Grandis JR, Melhem MF, Barnes EL, Tweardy DJ. Quantitative immunohistochemical analysis of transforming growth factor- $\alpha$ and epidermal growth factor receptor in patients with squamous cell carcinoma of the head and neck. Cancer 1996;78:1284-1292.

32. Rieske P, Kordek R, Bartkowiak J, Debiec-Rychter M, Bienhat W, Liberski PP. A comarative study of epidermal growth factor receptor (EGFR) and MDM2 gene amplification and protein immunoreactivity in human glioblastomas. Pol J Pathol 1998;49:145-149.

33. Goike HM, Asplund AC, Pettersson EH, Liu L, Ichimura K, Collins VP. Acquired rearrangement of an amplified epidermal growth factor receptor (EGFR) gene in a human gliobalstoma xenograft. J Neuropathol Exp Neurol 1999;58:697-701.

34. Messa C, Russo F, Caruso MG, Dileo A. EGF, TGFßa, and EGF-R in human colorectal adenocarcinoma. Acta Oncol 1998;37:285-289.

35. Wells A. The epidermal growth factor receptor (EGFR) - a new target in cancer therapy. Signal 2000;1:4-11.

36. Bartlett JM, Langdon SP, Simpson BJ, Stewart M, Katsaros D, Sismondi P, Love S, Scott WN, Williams AR, Lessells AM, Macleod KG, Smyth JF, Miller WR. The prognostic value of the epidermal growth factor receptor mRNA expression in primary ovarian cancer. $\mathrm{Br} J$ Cancer 1996;73:301-306.

37. Volm M, Rittgen W, Drings P. Prognostic value of ERBB-1, VEGF, cyclin A, FOS, JUN, and MYC in patients with squamous cell lung carcinomas. Br J Cancer 1998;77:1293-1296.

38. Maurizi M, Almadori G, Ferrandina G, Distefano M, Romanini ME, Cadoni G, Benedetti-Panici P, Paludetti G, Scambia G, Manucuso S. Prognostic significance of epidermal growth factor receptor in laryngeal sqamous cell carcinoma. Br J Cancer 1996;74:1253-1257.

39. Frederick L, Wang XY, Eley G, James CD. Diversity and frequency of epidermal growth factor receptor mutations in human glioblastomas. Cancer Res 2000; 60:1383-7.

40. Huang, HS, Nagane M, Klingbeil CK, Lin H, Nishikawa R, Ji XD, Huang CM, Gill GL, Wiley HS, Cavenee WK. The enhanced tumorigenic activity of a mutant epidermal growth factor receptor common in human cancers is mediated by threshold levels of constitutive tyrosine phosphorylation and unattenuated signaling. J Biol Chem 1997;272:2927-35.

41. Moscatello DK, Holgado-Madruga M, Godwin AK, Ramirez G, Gunn G, Zoltick PW, Biegel JA, Hayes RL, Wong AJ. Frequent expression of a mutant epidermal growth factor receptor in multiple human tumors. Cancer Res 1995;55:5536-9.

42. Nagane M, Coufal F, Lin H, Bogler O, Cavenee WK, Huang HJ. A common mutant epidermal growth factor receptor confers enhanced tumorigenicity on human glioblastoma cells by increasing proliferation and reducing apoptosis. Cancer Res 1996;56:5079-86.

43. Nishikawa R, Ji XD, Harmon RC, Lazar CS, Gill GN, Cavenee WK, Huang HJ. A mutant epidermal growth factor receptor common in human glioma confers enhanced tumorigenicity. Proc Natl Acad Sci U S A 1994;91:7727-31.

44. Batra SK, Castelino-Prabhu S, Wikstrand CJ, Zhu X, Humphrey PA, Friedman HS et al. Epidermal growth factor ligand-independent, unregulated, cell-transforming potential of a naturally occuring human mutant EGFRvIll gene. Cell Growth Differ 1995;6:1251-1259.

45. Moscatello DK, Montgomery RB, Sundareshan P, McDanel H, Wong MY, Wong AJ. Transformational and altered signal transduction by a naturally occurring mutant EGF receptor. Oncogene 1996;13:85-96.

46. Wong AJ, Ruppert JM, Bigner SH, Grzeschik CH, Humphrey PA, Bigner DS, Vogelstein B. Structural alterations of the epidermal growth factor receptor gene in human gliomas. Proc Natl Acad Sci U S A 1992;89:2965-9

47. Bigner SH, Humphrey PA, Wong AJ, Vogelstein B, Mark J, Friedman HS, Bigner DD. 1990. Characterization of the epidermal growth factor receptor in human glioma cell lines and xenografts. Cancer Res 50:8017-22. 
48. Montgomery RB, Moscatello DK, Wong AJ, Cooper AJ, Stahl WL. Differential modulation of mitogen-activated protein (MAP) kinase/ extracellular signal-related kinase kinase and MAP kinase activities by a mutant epidermal growth factor receptor. J Biol Chem 1995;270:30562-6.

49. Antonyak MA, Moscatello DK, Wong AJ. Constitutive activation of $\mathrm{c}-\mathrm{Jun} \mathrm{N}$-terminal kinase by a mutant epidermal growth factor receptor. J Biol Chem 1998;273:2817-22.

50. Rusch V, Baselga J, Cordon-Cardo C, Orazem J, Zaman M, Hoda S, McIntosh J, Kurie J, Dmitrovsky E. Differential expression of the epidermal growth factor receptor and its ligands in primary non-small cell lung cancers and adjacent benign lung. Cancer Res 1993;53:2379-2385.

51. Rusch V, Klimstra D, Venkatatraman E, Pisters PW, Langenfeld J, Dmitrovsky E. Overexpression of the epidermal growth factor receptor and its ligand transforming growth factor $\alpha$ is frequent in resectable non-small cell lung cancer but does not predict tumor porgression. Clin Cancer Res 1997;3:515-522.

52. Fontanini G, De Laurentiis M, Vignati S, Chine S, Lucchi M, Silvestri V, Mussi A, De Placido S, Tortora G, Bianco AR, Gullick W, Angeletti CA, Bevilacqua G, Ciardiello F. Evaluation of epidermal growth factor-related growth factors and receptors and of neoangiogenesis in completely resected stage I-IIIA non-small-cell lung cancer: amphiregulin and microvessel count are independent prognostic indicators of survival. Clin Cancer Res 1998;4:241-249.

53. Yoshida K, Hosoya Y, Sumi S, Honda M, Moriguchi H, Yano M, Ueda Y. Studies of the expression of epidermal growth factor receptor in human renal cell carcinoma: a comparison of immunohistochemical method versus ligand binding assay. Oncology 1997;54:220-225.

54. Walker RA, Dearing SJ. Expression of epidermal growth factpr receptor mRNA and protein in primary breast carcinomas. Breast Cancer Res Treat 1999;53:167-176.

55. Beckman MW, Niederacher D, Massenkeil G, Tutschek B, Beckmann A, Schenko G, Schnurch HG, Bender HG. Expression analyses od epidermal growth factor receptor and Her-2/neu: No advantage of prediction of recurrence or survival in breast cancer patients. Oncology 1996;53:441-447.

56. Fischer-Colbrie J, Witt A, Heinzl H, Speiser P, Czerwenka K, Sevelda P, Zeillinger R. EGFR and steroid receptors in ovarian carcinoma: Comparison with prognostic parameters and outcome of patients. Anticancer Res 1997;17:613-620.

57. Ekstrand AJ, James CD, Cavanee WK, Seliger B, Pettersson RF, Collins VP. Genes for epidermal growth factor receptor, transforming growth factor and their expression in human gliomas in vivo. Cancer Res 1991;51:2164-72.

58. Uegaki K, Nio Y, Inoue Y, Minari Y, Sato Y, Song MM, Dong M, Tamura K. Clinicopathological significance of epidermal growth factor and its receptor in human pancreatic cancer. Anticancer Res 1997; 17:3841-3848.

59. Chow N-H, Liu H-S, Lee EI, Chang CJ, Chan SH, Cheng HL, Tzai TS, Lin JS. Significance of urinary epidermal growth factor and its receptor expression in human bladder cancer. Anticancer Res 1997; 17:1293-1296.

60. Parker C, Roseman J, Bucana CD, J Histochem Cytochem 46:595-602, 1998.

61. Radinsky R, Risin S, Fan Z, Dong, Bielenberg, Bucana, Fidler. Level and function of epidermal growth factor receptor predict the metastatic potential of human colon carcinoma cells Clin Cancer Res 1995;1:19-31.

62. Grandis JR, Melhem MF, Gooding WE, Day R, Holst VA, Wagener MM, Drenning SD, Tweardy DJ. Levels of TGF-a and EGFR protein in head and neck squamous cell carcinoma and patient survival. J Natl Cancer Inst 1998;90:824-832.

63. Turkeri LN, Erton ML, Cevik I, Akdas A. Impact of the expression of epidermal growth factor, transforming growth factor alpha, and epidermal growth factor receptor on the prognosis of superficial bladder cancer. Urology 1998;51:645-649.

64. Selvaggi G, Novello S, Torri V, Leonardo E, De Giuli P, Borasio P, Mossetti C, Ardissone F, Lausi P, Scagliotti GV. Epidermal growth factor receptor overexpression correlates with a poor prognosis in completely resected non-small cell lung cancer. Ann Oncol 2004;15:28-32.

65. Veale D, Kerr N, Gibson GJ, et al. The relationship of quantitative epidermal growth factor receptor expression in non-small-cell lung cancer to long term survival. Anticancer Res 1997;17:3841-3848.

66. Pavelic K, Banjac Z, Pavelic J, Spaventi S. Evidence for a role of EGF receptor in the progression of human lung carcinoma. Anticancer Res 1993;13:1133-1137.

67. Klijn JG, Look MP, Portengen H, Alexieva-Figusch J, van Putten WL, Foekens JA. The prognostic value of epidermal growth factor-receptor (EGFR) in primary breast cancer: results of a 10-year follow-up study. Breast Cancer Res Treat 1994;29:73-83. 
68. Tsutsui S, Ohno S, Murakami S, Kataoka A, Kinoshita J, Hachitanda Y. Prognostic value of the combination of epidermal growth factor receptor and c-erbB2 in breast cancer. Surgery 2003;133:21921

69. Niikura H, Sasano H, Sato S, Yajima A. Expression of epidermal growth factor-related proteins and epidermal growth factor receptor in common epithelial ovarian tumors. Int $\mathrm{J}$ Gynecol Pathol 1997; 16:60-68.

70. Shinojima N, Tada K, Shiraishi S, Kamiryo T, Kochi M, Nakamura H, Makino K, Saya H, Hirano H, Kuratsu J, Oka K, Shimaru Y, Ushio Y. Prognostic value of epidermal growth factor receptor in patients with glioblatoma multiforme. Cancer Res 2003;63:6962-70.

71. Yamanaka Y, Friess H, Kobrin MA, Buchler M, Beger HG, Korc M. Coexpression of epidermal growth factor receptor and ligands in human pancreatic cancer is associated with enhanced tumor aggressiveness. Anticancer Res 1993;13:565-569.

72. Chua DT, Nicholls, JM, Sham JS, Au GK. Prognostic value of epidermal growth factor receptor expression in patients with advanced stage nasopharyngeal carcinoma treated with induction chemotherapy and radiotherapy. Int J Radiat Oncol Biol Phys 2004;59:11-20.

73. Ma BB, Poon, TC, To KF, Zee B, Mo FK, Chan CM, Ho S, Teo PM, Johnson PJ, Chan AT. Prognostic significance of tumor angiogenesis, Ki 67, p53 oncoprotein, epidermal growth factor receptor and HER 2 receptor protein expression in undifferentiated nasopharygeal carcinoma - a prospective study. Head Neck 2003;25:864-72.

74. Mayer A, Takimoto M, Fritz E, Schellander G, Kofler K, Ludwig H. The prognostic significance of proliferating cell nuclear antigen, epidermal growth factor receptor, and mdr gene expression in colorectal cancer. Cancer 1993;71:2454-2460.

75. Resnick MB, Routhier J, Konkin T, Sabo E, Pricolo VE. Epidermal growth factor receptor, o-Met, beta-catenin, and p53 expression as prognostic indicators in stage II colon cancer: a tissue microarray study. Clin Cancer Res 2004;10:3069-75.

76. Kopp R, Rothbauer E, Mueller E, Schildberg FW, Jauch KW, Pfeiffer A. Reduced survival of rectal cancer patients with increased tumor epidermal growth factor receptor levels. Dis Colon Rectum 2003;46:1391-9.

77. Neal DE, Sharples L, Smith K, Fennelly J, Hall RR, Harris AL. The epidermal growth factor receptor and the prognosis of bladder cancer. Cancer 1990;65:1619-1625.

78. Ogawa J, Iwazaki M, Inoue H, Koide S, Shohtsu A. Immunohistochemical study of glutathione-related enzymes and proliferative antigens in lung cancer. Relation to cisplatin-sensitivity. Cancer 1993;71:2204-2209.

79. Santini J, Formento J-L, Francoual M, Milano G, Schneider M, Dassonville O, Demard F. Characterization, quantification, and potential clinical value of the epidermal growth factor receptor in head and neck squamous cell carcinomas. Head Neck 1991;13:132-139.

80. Etienne MC, Pivot X, Formento JL, Bensadoun RJ, Formento P, Dassonville O, Francoual M, Poissonnet G, Fontana X, Schnieder M, Demard F, Milano G. A multifactorial approach including

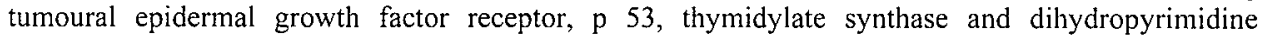
dehydrogenase to predict treatment outcome in head and neck cancer patients receiving 5-fluoruracil. Br J Cnacer 1999;79:1864-1869.

81. Ang KK, Andratschke NH, Milas L. Epidermal growth factor receptor and response of head-and-neck carcinoma to therapy. Int J Radiat Oncol Biol Phys. 2004;58:959-65.

82. Giralt J, Eraso A, Armengol M, Rossello J, Majo J, Ares C, Espin E, Benavente S, de Torres I. Epidermal growth factor receptor is a predictor of tumor response in locally advanced rectal cancer patients treated with preoperative radiotherapy. Int J Radiat Oncol Biol Phys. 2002;54:1460-5.

83. Zhu A, Shaeffer J, Leslie S, Kolm P, El-Mahdi AM. Epidermal grwoth factor receptor: An independent predictor of survival in astrocytic tumors given definitive irradiation. Int $J$ Radiation Oncology Bol Phys 1996;34:809-815.

84. Pillai $\mathrm{M}$, Jayaprakash $\mathrm{PG}$, Nair $\mathrm{M}$. Tumour-proliferative fraction and growth factor expression as markers of tumour response to radiotherapy in cancer of the uterine cervix. J Cancer Res Clin Oncol 1998; 124:456-461.

85. Akimoto T, Hunter NR, Buchmiller L, Mason KA, Ang KK, Milas L. Inverse relationship between epidermal growth factor receptor expression and radiocurability of murine carcinomas. Clin Cancer Res 1999;5:2884-2890. 
86. Balaban N, Moni J, Shannon M, Dang L, Murphy E, Goldkorn T. The effect of ionising radiation on signal transduction: antibodies to EGF receptors sensitise A431 cells to radiation. Biochim Biophys Acta 1996;1314:147-156.

87. Milas L, Mason K, Hunter N, Petersen S, Yamakawa M, Ang K, Mendelsohn J, Fan Z. In vivo enhancement of tumor radioresponse by $\mathrm{C} 225$ antiepidermal growth factor receptor antibody. Clin Cancer Res 2000;6: 701-708.

88. Huang SM, Harari PM. Modulation of radiation response after epidermal growth factor receptor blockade in squamous cell carcinomas: inhibition of damage repair, cell cycle kinetics, and tumor angiogenesis. Clin Cancer Res 2000;6:2166-74.

89. Bonner JA, Harari PM, Giralt J, Azarnia N, Cohen RB, Kies MS, Baselga J, Ang KK. Cetuximab prolongs survival in patients with locoregionally advanced squamous cell carcinoma of head and neck: a phase III study of high dose radiation therapy with or without cetuximab. Proc Am Soc Clin Oncol 2004 , abstr 5507.

90. Woodburn, JR. The epidermal growth factor receptor and its inhibition in cancer therapy. Pharmacol Ther. 1999;82:241-50. Review.

91. Ranson M Hammond LA, Ferry D, et al. ZD1839, a selective oral epidermal growth factor receptortyrosine kinase inhibitor, is well tolerated and active in patients with solid, malignant tumors: results of a phase I trial. J Clin Oncol 2002;20:2240-50.

92. Herbst RS, Maddox AM, Rothenberg ML, Small EJ, Rubin EH, Baselga J, Rojo F, Hong WK, Swaisland H, Averbuch SD, Ochs J, LoRusso PM. Selective oral epidermal growth factor receptor tyrosine kinase inhibitor ZD1839 is generally well-tolerated and has activity in non-small-cell lung cancer and other solid tumors: results of a phase I trial. J Clin Oncol 2002;20:3815-25.

93. Baselga J, Rischin D, Ranson M, Calvert H, Raymond E, Kieback DG, Kaye SB, Gianni L, Harris A, Bjork T, Averbuch SD, Feyereislova A, Swaisland H, Rojo F, Albanell J. Phase I safety, pharmacokinetic, and pharmacodynamic trial of ZD1839, a selective oral epidermal growth factor receptor tyrosine kinase inhibitor, in patients with five selected solid tumor types. J Clin Oncol 2002;20:4292-302.

94. Kris MG, Natale RB, Herbst RS, Lynch TJ Jr, Prager D, Belani CP, Schiller JH, Kelly K, Spiridonidis H, Sandler A, Albain KS, Cella D, Wolf MK, Averbuch SD, Ochs JJ, Kay AC. Efficiacy of gefinitib, an inhibitor of the epidermaL growth factor receptor tyrosine kinase, in symptomatic patients with non-small cell lung cancer: a randomized trial. JAMA 2003;290:2149-58.

95. Fukuoka M, Yano S, Giaccone G, Tamura T, Nakagawa K, Douillard JY, Nishiwaki Y, Vansteenkiste J, Kudoh S, Rischin D, Eek R, Horai T, Noda K, Takata I, Smit E, Averbuch S, Macleod A, Feyereislova A, Dong RP, Baselga J. Multi-institutional randomised phase II trial of gefitinib for previously treated patients with advanced non-small-cell-lung cancer. J Clin Oncol 2003;21:2237-46.

96. Giaccone G, Herbst RS, Manegold C, Scagliotti G, Rosell R, Miller V, Natale RB, Schiller JH, Von Pawel J, Pluzanska A, Gatzemeier U, Grous J, Ochs JS, Averbuch SD, Wolf MK, Rennie P, Fandi A, Johnson DH.. Gefitinib in combination with gemicitabine and cisplatin in advanced non-small-cell lung cancer: a phase III trial - INTACT 2. J Clin Oncol 2004;22:777-84.

97. Herbst RS, Giaccone G, Schiller JH, Natale RB, Miller V, Manegold C, Scagliotti G, Rosell R, Oliff 1, Reeves JA, Wolf MK, Krebs AD, Averbuch SD, Ochs JS, Grous J, Fandi A, Johnson DH. Gefitinib in combination with paclitaxel and carboplatin in advanced non-small-cell lung cancer: a phase III trial INTACT 2. J Clin Oncol 2004;22:785-94.

98. Lynch TJ, Bell DW, Sordella R, Gurubhagavatula S, Okimoto RA, Brannigan BW, Harris PL, Haserlat SM, Supko JG, Haluska FG, Louis DN, Christiani DC, Settleman J, Haber DA. Activating mutations in the epidermal growth factor receptor underlying responsiveness of non-small-cell-lung cancer to gefinitinib. N Engl J Med 2004;350:2129-38.

99. Schmidt-Ullrich RK, Contessa JN, Dent P, Mikkelsen RB, Valerie K, Reardon DB, Bowers G, Lin PS. Molecular Mechanisms of radiation-induced accelerated repopulation. Radiat Oncol Invest 1999:7:321-330.

100. Huang SM, Bock JM, Harari PM. Epidermal growth factor receptor blockade with C225 modulates proliferation, apoptosis, and radiosensitivity in squamous cell carcinomas of the head and neck. Cancer Res 1999;59:1935-40.

101. Huang SM, Li J, Armstrong EA, Harari PM. Modulation of radiation response and tumor-induced angiogenesis after epidermal growth factor receptor inhibition by ZD 1839 (Iressa). Cancer Res $2002 ; 62: 4300-6$ 
102. Rodeck U, Jost M, Kari C, Shih DT, Lavker RM, Ewert DL, Jensen PJ. EGFR dependent regulation of kerationcyte survival. J Cell Science 1997;110:113-21.

103. Modjtahedi H, Affleck K, Stubberfield C, Dean C. EGFR blockade by tyr kinase inhibitor or monoclonal antibody inhibits growth, directs terminal differentiation and induces apoptosis in human squamous cell carcinoma HN5. In J Oncol 1998;13:335-342.

104. Gibson S, Tu S, Oyer R, Anderson SM, Johnson GL. Epidermal growth factor protects epithelial cells against Fas- induced apoptosis. Requirement for Akt activation. J Bio Chem 1999;274:17612-17618.

105. Fox SB, gatter KC, Harris AL. Tumor angiogenesis. J Pathol 1996:179:232-237.

106. Schmidt-Ulirich RK, Valerie K, Fogleman PB, Walters J. Radiation-induced auto-phosphorylation of epidermal growth factor receptor in human malignant mammary and squamous epithelial cells. Radiat Res 1996;145:79-83.

107. Schmidt-Ullrich RK, Mikkelsen RB, Dent P, Todd DG, Valerie K, Kavanagh BD et al. Radiationinduced proliferation of the human A431 squamous carcinoma cells is dependent on EGFR tyrosine phosphorylation. Oncogene 1997;15:1191-1197.

108. Reardon DR, Contessa JN, Mikkelsen RB, Valerie K, Amir C, Dent P, Schmidt-Ullrich RK. Dominant negative EGFR-CD533 and inhibition of MAPK modify JNK1 activation and enhance radiation toxicity of human mammary carcinoma cells. Oncogene 1999;18:4756-4766.

109. Denekamp J. Changes in the rate of repopulation during multi-fraction irradiation of mouse skin. $\mathrm{Br} \mathrm{J}$ Radiol 1973;46:381-392.

110. Westphal M, Meima L, Szonyi E, Lofgren J, Meissner H, Hamel W, et al. Heregulins and the ErbB2/3/4 receptors in gliomas. J Neurooncol 1997;35:335-46.

111. Contessa JN, Reardon DB, Todd D, Dent P, Mikkelsen RB, Valerie K, Bowers GD, Schmidt-Ullrich RK. The inducible expression of dominant negative epidermal growth factor receptor CD533 results in radiosensitization of human mammary carcinoma cells. Clin Cancer Res 1999;5:405-411.

112. Goldkorn T, Balaban N, Shannon M, Matsukuma K. EGF receptor phosphorylation is affected by jonizing radiation. Biochim Biophys Acta 1997;1358:289-99.

113. Schmidt-Ullrich RK, Valerie KC, Chan W, McWilliams D. Altered expression of epidermal growth factor receptor and estrogen receptor in $\mathrm{MCF}-7$ cells after singla and repeated radiation exposures. Int J Radiat Oncol Biol Phys 1994;29:813-9.

114. Kavanagh BD, Lin PS, Chen P, Schmidt-Ullrich RK. Radiation-induced enhanced proliferation of human squamous cancer cells in vitro: A release from inhibition by epidermal growth factor. Clin Cancer Res 1995; 1:1557-1562.

115. Carter S, Auer KL, Reardon DB, Birrer M, Fisher PB, Valerie K, Schmidt-Ullrich RK, Mikkelsen R, Dent $P$. Inhibition of the mitogen activated protein (MAP) kinase cascade potentiates cell killing by low dose ionizing radiation in A431 human squamous carcinoma cells. Oncogene 1998;16:2787-2796.

116. Withers HR, Taylor JMG, Maciejewiski B. The hazard of accelerated tumor clonogen repopulation during radiotherapy. Acta Oncol 1988:27:131-146.

117. Bentzen SM, Thames HD. Clinical evidence for tumor clonogen regeneration: interpretations of the data. Radiother Oncol 1991;22:161-66.

118. Withers HR, Peters LJ, Taylor JM, Owen JB, Morrison WH, Schultheiss TE, Kean T, O'Sulivan B, van Dyk J, Gupta N, et al. Local control of carcinoma of the tonsil by radiation therapy: an analysis of patterns of fractionantion in nine institutions. Int J Radiat Oncol Biol Phys 1995;33:549-562.

119. Fowler JF, Lindstrom MH. Loss of local control with prolongation in radiotherapy. Int J Radiat Oncol Biol Phys 1992;23:457-467.

120. Ang KK, Peters LJ. Concomitant boost radiotherapy in the treatment of head and neck cancers. Semin Radiat Oncol 1992;2:31-33.

121. Schmidt-Ullrich RK, Johnson CR, Wazer DE, Masko G, Chasin WD, Karmody CS. Accelerated hyperfractionated irradiation for advanced carcinoma of the head and neck: Concomitant boost technique. Int J Radiat Oncol Biol Phys 1991;21:562-568.

122. Wang CC. Local control of oropharyngeal carcinoma after two acceleraled hyperfractionation radiation therapy schemes. Int J Radiat Oncol Biol Phys 1988;14:1143-1146. 


\section{Chapter II}

II.1. The relative role of ErbB 1-4 receptor tyrosine kinases in radiation signal transduction responses of human carcinoma cells

Published in: Oncogene. 20, 1388-1397, $2001(\mathrm{IF}=6.74)$

G Bowers, D Reardon, T Hewitt, P Dent, R B Mikkelsen, K Valerie, G Lammering, C Amir and R K Schmidt-Ullrich 


\section{Summary}

Activation of the epidermal growth receptor (ErbB1) occurs within minutes of a radiation exposure. Immediate downstream consequences of this activation are currently indistinguishable from those obtained with growth factors (GF), e.g. stimulation of the pro-proliferative mitogen-activated protein kinase (MAPK). To identify potential differences, the effects of GFs and radiation on other members of the ErbB family have been compared in mammary carcinoma cell lines differing in their ErbB expression profiles. Treatment of cells with EGF (ErbB1-specific) or heregulin (ErbB4specific) resulted in hierarchic transactivations of ErbB2 and ErbB3 dependent on GF binding specificity. In contrast, radiation indiscriminately activated all ErbB species with the activation profile reflecting that cell's ErbB expression profile. Downstream consequences of these ErbB interactions were examined with MAPK after specifically inhibiting ErbBl (or 4) with tyrphostin AG1478 or ErbB2 with tyrphostin AG825. MAPK activation by GFs or radiation was completely inhibited by AG1478 indicating total dependance on ErbB1 (or 4) depending on which ErbB is expressed. Inhibiting ErbB2 caused an enhanced MAPK response simulating an amplified ErbB1 (or 4) response. Thus ErbB2 is a modulator of ErbB1 (or 4) function leading to different MAPK response profiles to GF or radiation exposure. 


\section{II.1.1 Introduction}

The ErbB receptor Tyr kinases (RTK) represent an interactive network of 170-190 kD transmembrane proteins, with binding sites for ligands of the epidermal growth factor (EGF) family at the extracellular $\mathrm{NH}_{2}$-terminal domain. The cytoplasmic, $\mathrm{COOH}$-terminal portions of the receptors carry Tyr, Ser, and Thr residues, the phosphorylation states of which are critical for their signaling functions $(14,31,34)$. Receptor dimerization upon GF binding results in activation of EGF receptor (ErbB1) and other ErbB species seen as receptor phosphorylation at defined Tyr residues through intrinsic kinase activity $(14,19,21,34)$. The hierarchy of interactions between the ErbB receptors involves both homo- and heterodimer formation and is determined by the specificities of ErbB1, -3 , and -4 for defined GFs (14,19,21,34). Based on current information, only ErbB1 and ErbB4 express both GF binding and functional cytoplasmic kinase domains. ErbB2 is a constitutively active receptor for which a GF ligand has not yet been identified $(21,23)$. In contrast, ErbB3 shares GF binding specificity with ErbB4 but lacks intrinsic kinase activity. Because of these properties, ErbB2 and ErbB3 may primarily function as modulators of ErbB1 and ErbB4 activities $(30,31,34)$.

The relative expression levels and activities of the different ErbB molecules in a given cell can determine the balance between cytoprotective and cytotoxic responses to ErbB activation by GFs and cytotoxic agents (37). As a result of receptor activation, downstream signals are channeled through adaptor proteins and exchange factors to the cytoprotective mitogen-activated protein kinase (MAPK)/phosphatidyl inositol-3-kinase (P13K), and the stress pathways invovling activation of Jun-N-terminal kinase (JNK) and p38 kinase (reviewed in 37,38).

In carcinoma and malignant glioma cells the ErbB receptors play critical roles in facilitating autocrine growth regulation $(16,19,21,23,24,32,34)$. There is also increasing evidence that ErbB receptors participate in the responses of tumor cells to genotoxic agents, such as ionizing radiation (e.g. 27). This is reflected in the fact that single and repeated radiation exposures, as applied during clinical radiotherapy, can activate ErbB RTKs and result in cytoprotective and cytotoxic signals mediating overall cellular responses of proliferation and apoptosis, respectively $(14,27,32,38,43)$. The discovery that radiation-induced ErbBl activation can initiate proliferation (37) through the MAPK cascade has not only identified a mechanism underlying accelerated repopulation but has also opened new avenues for therapeutic intervention using ErbBl as a target $(2,11,23,39)$. While radiation exerts similar effects as GFs with respect to receptor activation there are fundamental differences. GFs induce activation responses through a hierarchy of primary and secondary reactions that are driven by the specificities of receptor-GF interactions. In contrast, radiation can be 
expected to exert similar effects on all ErbB receptors and, therefore, indiscriminately activate all ErbB molecules expressed by a given tumor cell. If the varied expression and activation profiles of ErbB receptors determine the activation of distinct response pathways, radiation and GFs could generate qualitatively and quantitatively different signals along cytoprotective and cytotoxic pathways. This study examines radiation and GF effects in two autocrine growth regulated mammary carcinoma cells (MCC) expressing different ErbB RTK profiles. We describe differences in the interactions between ErbB1 or ErbB4 with ErbB2 which result in distinct MAPK activation responses.

\section{II.1.2. Materials and methods}

\section{II.1.2.1. Reagents}

Unless specified otherwise, all reagents were obtained from Sigma Chemical Co. (St. Louis, MO, USA). Tyrphostin protein kinase inhibitors, AG1478 and AG825, with specificities for ErbB1/ErbB4 and ErbB2, respectively, were from Calbiochem (San Diego, CA, USA).

\section{II.1.2.2. Antibodies, growth factors, and inhibitors}

The monoclonal antibodies $(\mathrm{mAb})$ used for the immunoprecipitation of ErbB1 (Ab-5) and detection of phospho-Tyr (Ab-2) levels were obtained from Calbiochem (Calbiochem-Novabiochem International; San Diego, CA, USA). MAbs used for the immunoprecipitation of ErbB2 (Ab-11), ErbB3 (Ab-4), and ErbB4 (Ab-1), as well as those used for Western blot detection of ErbB1, -2, -3, and $-4, \mathrm{Ab}-14, \mathrm{Ab}-10, \mathrm{Ab}-7$, and Ab-4, respectively, were obtained from Neomarkers (Fremont, $\mathrm{CA}, \mathrm{USA})$. The secondary $\mathrm{Ab}$, an anti-mouse alkaline phosphatase conjugate, was from Promega (Madison, WI, USA). Transforming growth factor- $\alpha$ (TGF- $\alpha$ was from Oncogene Sciences (Uniondale, NY, USA), and EGF was purchased from Sigma Chemical Co. (St. Louis, MO, USA) and heregulin $\alpha 1$ (HRG) from Neomarkers (Fremont, CA, USA).

\section{II.1.2.3. Maintanance of cells}

A431 human SCCs and MDA-MB-23I (MDA) and T47D human MCCs were obtained from the American Type Tissue Collection (ATTC; Rockville, MD, USA). A431 and T47D cells were maintained in RPMI-1640 supplemented with $10 \%$ fetal bovine serum (RPMI/10\%FBS) and MDA cells were maintained in RPMI/5\%FBS; routine antibiotics were 1000 units/ml penicillin and 1 $\mathrm{mg} / \mathrm{ml}$ streptomycin. Mycoplasma testing was performed monthly.

Cells were stored as mycoplasma-negative frozen stocks at $-80^{\circ} \mathrm{C}$. To assure consistent radiation and GF responses, cells were derived from frozen stocks and maintained in continuous culture for 
maximally 6 weeks; thus, experiments were performed between weeks 2 and 6 after thawing $(36,39)$.

\section{II.1.2.4. Treatment of cells with EGF and radiation}

For all protein and kinase assays, cell culture conditions were maintained as previously described $(32,39)$. Prior to exposure to EGF at $10 \mathrm{ng} / \mathrm{ml}$ or to 2 Gy of ionizing radiation, cells were maintained in RPMI/0.5\%FBS for $24 \mathrm{~h}$. Irradiation was at a dose rate $1.1 \mathrm{~Gy} / \mathrm{min}$ using a Co-60 source. Similarly, cells were exposed to EGF at specified concentrations 5 min prior to quantification of ErbB1 phospho-Tyr levels and MAPK activity. For studies involving AG1478 and AG825, cells were pre-incubated with the inhibitor at concentrations of $5 \mu \mathrm{M}$ for 30 min prior to exposures to EGF or radiation. These drug concentrations and incubation conditions were developed in earlier titration studies (41, unpublished data) that demonstrated the desired specificity and correspond to the relative inhibitor constants defined in vitro for the two tyrphostins $(25,42)$.

\section{II.1.2.5 Immunoprecipitation}

Immunoprecipitation of ErbB receptors and MAPK was performed as previously described $(11,32)$. After treatment, cells were rinsed once with ice-cold PBS and snap-frozen on dry ice. Cell lysates were prepared in $25 \mathrm{mM}$ Tris, pH 7.4, $50 \mathrm{mM}$ ßGP, $1.5 \mathrm{mM}$ EGTA, $0.5 \mathrm{mM}$ EDTA, $1.0 \mathrm{mM}$ sodium pyrophosphate, $1.0 \mathrm{mM}$ sodium vanadate, $10 \mu \mathrm{g} / \mathrm{ml}$ leupeptin, $10 \mu \mathrm{g} / \mathrm{ml}$ aprotinin, $1 \mathrm{mM}$ benzamidine, $100 \mu \mathrm{g} / \mathrm{ml}$ PMSF, 1\% Triton. Cell lysates were normalized according to protein concentrations using the BCA kit (BioRad; Hercules, CA, USA). For immunoprecipitation of ErbB molecules, equal amounts of cell lysate were incubated with the respective $\mathrm{mAb}$ with gentle agitation for $1.5 \mathrm{~h}$ at $4^{\circ} \mathrm{C}, 50 \mu \mathrm{l}$ of protein A-agarose (BioRad; Hercules, CA, USA) added, and reacted for an additional $45 \mathrm{~min}$. The agarose was washed twice with ice-cold lysis buffer and boiled in $50 \mu \mathrm{l}$ sample buffer, $5 \%$ glycerol, $4 \%$ SDS, $144 \mathrm{mM} \beta$-mercaptoethanol, $100 \mathrm{mM}$ Tris, $\mathrm{pH}$ 6.8. Samples were subjected to immediate SDS-polyacrylamide gel electrophoresis or stored at $80^{\circ} \mathrm{C}$. For the quantification of kinases, the immune complexes were washed with assay buffer prior to the assay.

\section{II.1.2.6. Western blotting}

Samples were boiled again upon thawing and fractionated in 6\% SDS-polyacrylamide gels. Electrophoresis at $130 \mathrm{~V}$ for $2 \mathrm{~h}$ was followed by overnight transfer to nitrocellulose membranes (Micron Separations Inc.; Westborough, MA, USA). Blots were blocked in $0.05 \%$ Tween/PBS (TPBS) supplemented with 3\% blotting grade milk (BioRad; Hercules, CA, USA) for $2 \mathrm{~h}$, and reacted with secondary $\mathrm{mAb}$ in the same TPBS/3\% milk mixture. Blots were then washed in TPBS 
and treated with anti-mouse alkaline phosphatase-conjugated $\mathrm{Ab}$. Detection was by CDP-Star Chemiluminescence (Tropix; Bedford, MA, USA). Relative levels of protein expression and ErbB receptor Tyr phosphorylation were quantified using Microsoft Scanwin ${ }^{\text {TM }}$.

\section{II.1.2.7. Immune complex assays for MAPK activity}

The assay for MAPK activity has also been previously described (32). Briefly, immunoprecipitates were incubated with $40 \mu \mathrm{IH}_{2} 0$ containing the appropriate substrates, namely $20 \mu \mathrm{g}$ of myelin basic protein (MBP) for MAPK. The kinase reaction was initiated by addition of $10 \mathrm{ul}$ of $5 \mathrm{x}$ kinase buffer (125 mM $\beta$-glycerophosphate, $\mathrm{pH} 7.4,75 \mathrm{mM} \mathrm{ATP}$, and $\gamma\left[{ }^{32} \mathrm{P}\right]$-ATP) and continued at $37^{\circ} \mathrm{C}$ for 30 min. Incorporation of ${ }^{32} \mathrm{P}$ into $\mathrm{MBP}$ was quantified by adsorption to $\mathrm{P} 81$ followed by liquid scintillation spectroscopy (32).

\section{II.1.2.8. Biostatistical analyses}

For all the outcomes, an $F$ test for equality of the variances of the two samples was performed. If the variances were equal, two sample Student's t-test was performed. If the variances were unequal, a Welch modified two sample Student's t-test was performed

\section{II.1.3 Results}

\section{II.1.3.1. ErbB RTK expression profiles in human carcinoma cells}

As previously described, exposure of human MCCs and SCCs to ionizing radiation in the clinically relevant dose range of 1.5 Gy activates ErbB1 within minutes and results in signaling along the MAPK and JNK cascades $(32,36,37,39)$. The focus of the present study was to examine in more detail the role of ErbB1 and other ErbB RTKs in cellular radiation responses. Because of the established similarities, we continue to compare radiation-induced activation with that of GF's. This study was initiated by first establishing the ErbB RTK expression profiles of different carcinoma cells. 


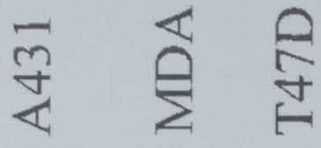

ErbB1

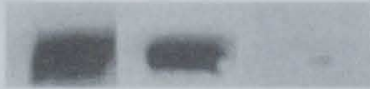

ErbB2

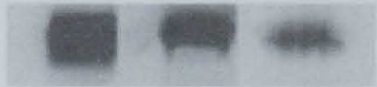

ErbB3

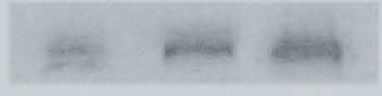

ErbB4

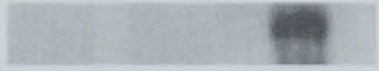

Figure 1

Figure II.1.1. ErbB1-4 expression profiles in human carcinoma cell lines. Cell lysates were prepared from A431, MDA and T47D carcinoma cells and divided into equal aliquots for immunoprecipitation of the different ErbB species. The immunoprecipitates were fractionated by SDS gel electrophoresis, transferred to nitrocellulose, and probed with ErbB specific mAbs. Results are representative of triplicate experiments for each cell line

Under the conditions employed, MDA cells expressed similar levels of ErbB1 and ErbB2 receptors and substantially lower levels of ErbB3 (Figure 1). In comparison, A431 SCCs expressed higher levels of ErbB1 consistent with previous reports $(19,22,34)$; the relative expression levels of ErbB2 and ErbB3 proteins were similar to those in MDA cells. In both cell lines ErbB4 protein was not detected by immunoprecipitation (Figure 1). As an example for varied expression of ErbB RTKs by carcinoma cell lines, we also included T47D MCCs into our analyses. These cells expressed comparatively high levels of ErbB4 and ErbB2 with lower amounts of ErbB3 and undetectable levels of ErbB1 protein (Figure 1).

\section{II.1.3.2. GF-induced activation of ErbB RTKs in human carcinoma cells}




\section{A. MDA-MB-231}

\section{B. T47D}

$$
1.016 .416 .316 .9<\text { Fold }
$$

ErbB1

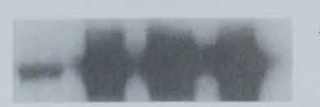

\section{$1.0 \quad 1.4 \quad 1.5 \quad 1.7$}

ErbB2

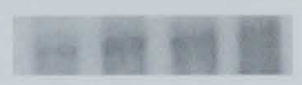

$\begin{array}{llll}1.0 & 1.0 & 0.9 & 0.7\end{array}$

ErbB3

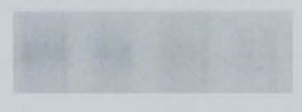

Activation

ErbB1

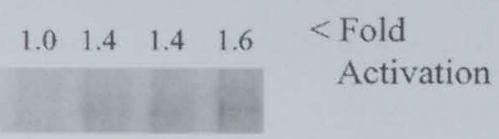

$\begin{array}{llll}1.0 & 1.6 & 1.8 & 2.0\end{array}$

ErbB2

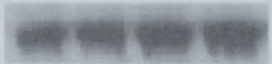

$1.0 \quad 23.4 \quad 25.622 .8$

ErbB3

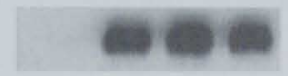

$\begin{array}{llll}1.0 & 22.5 & 21.320 .8\end{array}$

C $\quad 1 \quad 5 \quad 10 \quad \min$

ErbB4

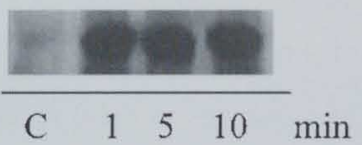

\section{Figure 2}

Figure II.1.2. GF-induced activation of ErbBI-4 in MDA and T47D MCCs. Cells were treated with 10 $\mathrm{ng} / \mathrm{ml} E G F$ or HRG for the indicated times before cell lysate preparation. Equal amounts of cell lysates were used for immunoprecipitation of the different ErbB molecules. The immunoprecipitates after fractionation by SDS gel electrophoresis and transfer to nitrocellulose were probed with phospho-Tyr specific $m A b$ as a measure of receptor activation. The results shown for each cell line are from one cell preparation representative of results obtained in three separate experiments

Since the ErbB receptor expression profiles varied most significantly between MDA and T47D MCCs, the effects of GF and radiation exposure on ErbB interactions and critical downstream responses were studied in these two cell lines. Exposure of MDA cells to EGF resulted in a maximum 16-fold activation of ErbB1 (Figure 2a). The 1.7-fold increase in ErbB2 Tyr phosphorylation in this experiment reflected the lower end of the extent of transactivation that was as high as eightfold (see Figures 4 and 5 for additional data). The increased Tyr phosphorylation of ErbB2 resulted from transactivation with ErbB1, since EGF cannot directly activate ErbB2 (14). No activation of ErbB3 was detected under the conditions employed.

Treatment of T47D cells with HRG, a ligand for both ErbB3 and ErbB4, resulted in similar > 20fold stimulations of ErbB3 and ErbB4 phospho-Tyr levels (Figures 2b). As with the MDA cells, the simultaneous 1.6-2.0-fold stimulation of ErbB2 was likely to reflect trans-activation. Despite our 
inability to demonstrate the presence of ErbB1 protein, a modest 1.5-fold trans-activation of ErbB1 suggested low-level expression of this receptor, since the detection by mAb of multiple Tyr phosphorylation sites was likely to be more sensitive than that of protein.

\section{II.1.3.3. Radiation-induced ErbB activation}

The ErbB RTK activation by GF's requires specific ligand-receptor interactions, whereas radiation is expected to indiscriminately activate ErbB receptors due to the random nature of ionization events. For this reason we compared the radiation- and GF-induced ErbB activation profiles. The radiation dose of $2 \mathrm{~Gy}$ was selected since this is within the clinical range and in previous experiments the ErbBI response to radiation was shown to saturate between 2-5 Gy in all cells examined $(12,32,36,41)$. The exposure of MDA cells to 2 Gy resulted in similar and simultaneous threefold activations of both ErbB1 and ErbB2 (Figure 3a) and a slightly lower twofold activation of ErbB3. In seven independent experiments, the average fold activations for ErbB1 and ErbB2 were $2.6 \pm 0.7(\mathrm{P}<.00002)$ and $2.4 \pm 0.9(\mathrm{P}<.002)$, respectively. The average radiation-induced activation of ErbB3 in three independent experiments was $2.1 \pm 0.5(\mathrm{P}<.02)$. Similar early $(1-2 \mathrm{~min}$ post-irradiation) changes in ErbB receptor Tyr phosphorylation were also seen with T47D cells as shown in the representative experiment in Figure $3 \mathrm{~b}$. In three independent experiments radiation induced $2.8 \pm 0.3(\mathrm{P}<.0005), 2.1 \pm 0.4(\mathrm{P}<.01)$, and $2.3 \pm 0.4(\mathrm{P}<.005)$ fold increases in Tyr phosphorylation of ErbB4, ErbB3, and ErbB2, respectively in T47D cells. A later increase in Tyr phosphorylation of the ErbB receptors in T47D ( $\geq 10 \mathrm{~min}$ ) probably reflects initiation of a radiationinduced, but ligand-dependent second phase of ErbB phosphorylation as previously reported (12).

\section{II.1.3.4. Differences in ErbB receptor response profiles after exposure of cells to GFs or radiation}


The activation profiles of ErbB receptors in MDA and T47D cells after EGF and HRG treatment, respectively, were characterized by substantially different levels of enhanced Tyr phosphorylation. The strongest response was seen for those ErbB receptors that bind ligand with highest affinity. This was supported by the findings that EGF did not stimulate Tyr phosphorylation of ErbB4 (data

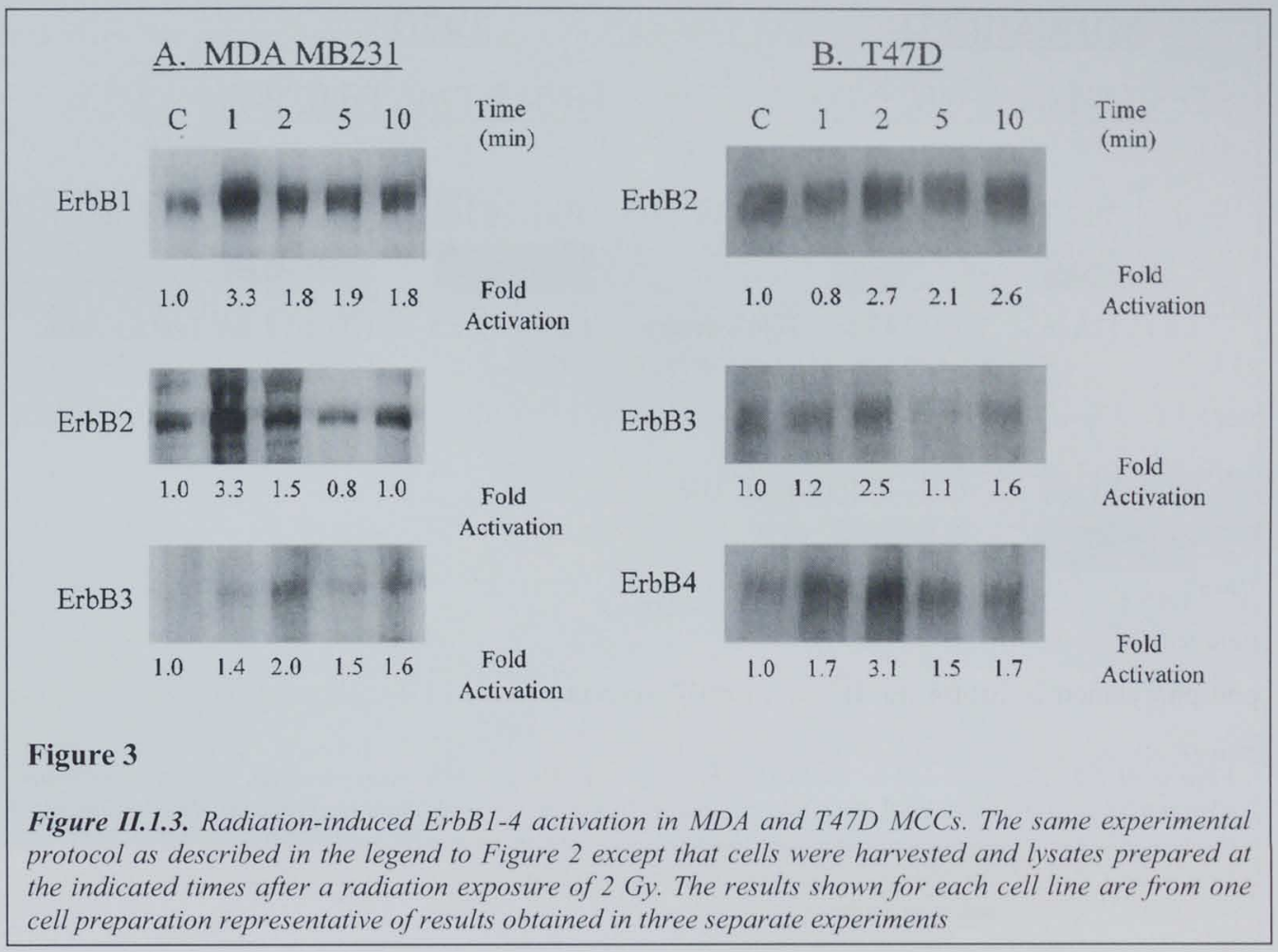

not shown) and HRG exerted a relatively small effect on ErbB1 phosphorylation (Figure 2b). Therefore, the activation profiles induced by GF are driven by receptor-ligand interaction and are independent of ErbB expression. In comparison, radiation-induced ErbB receptor activation is fundamentally different. Although the degree of activation is less than that obtained with GFs, radiation induces an indiscriminate activation of ErbB receptors as demonstrated by similar increases in Tyr phosphorylation of all receptors expressed by a given cell. This finding suggests that the response to radiation is primarily determined by the ErbB expression profile of that cell (Figure 3a,b). The indiscriminate ErbB activation by radiation precluded a direct analysis of transactivation between ErbB molecules. However, these secondary receptor interactions between ErbB1/ErbB4 and ErbB2 were measurable since GF-mediated enhanced Tyr phosphorylation of ErbB2 can only occur through transactivation due to a lack of ligand binding sites for ErbB2 (14). 
The extent of heterodimerization was quantified in MDA cells through exposure to increasing concentrations of the two physiological ligands, EGF and TGF- $\alpha$, at concentrations between 1 and $100 \mathrm{ng} / \mathrm{ml}$ (Figure 4a). Similarly, T47D cells were exposed to HRG over the same concentration range (Figure 4b). In MDA and T47D cells, maximal 16- and 9-fold activations of ErbB1 and

MDA MB 231

\section{ErbB1 P-Tyr ErbB2 P-Tyr}

$0 \quad 110100$

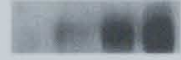

1.03 .512 .616 .3
$0 \quad 110100 \mathrm{ng} / \mathrm{ml}$ EGF

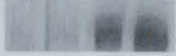

$1.0 \quad 1.44 .36 .8$ Fold activation

\section{T47D}

\section{ErbB4 P-Tyr ErbB2 P-Tyr}

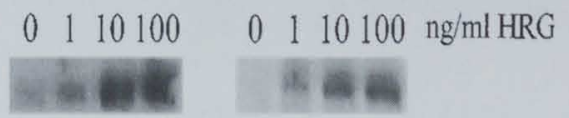

$1.01 .26 .38 .5 \quad 1.01 .42 .8 \quad 4.0$ Fold activation
$0 \quad 110100$

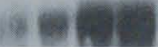

1.02 .48 .79 .3
$0 \quad 110100 \mathrm{ng} / \mathrm{ml} \mathrm{TGF} \alpha$

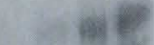

1.0 1.73.95.3 Fold activation

\section{Figure 4}

Figure II.1.4. Transactivation of ErbB2 by EGF or HRG. Cells were treated with the indicated concentration of EGF or HRG for 5 min prior to cell harvesting and lysate preparation. The lysates were divided into two equivalent aliquots for immunoprecipitation of ErbB1 and ErbB2 for MDA cells and ErbB4 and ErbB2 for T47D cells. Immunoprecipitates were fractionated, blotted, and probed for phospho-Tyr as a measure of receptor activation.

ErbB4 Tyr phosphorylation, respectively, were observed after $10 \mathrm{~min}$ exposures to GF. Under these conditions, secondary transactivations of ErbB2 amounted to maximum 6.8- (MDA) and 4.0(T47D) fold increases in Tyr phosphorylation (Figure 4a,b).

Quantitative aspects of ErbB1/ErbB2 interactions after exposure to radiation or EGF were more fully analysed in seven independent experiments with MDA cells (Figure 5). The radiation-induced activations of ErbB1 and ErbB2 were measured as similar \pm twofold increases in Tyr phosphorylation. In contrast, EGF induced a $>10$-fold activation of ErbB1 and an average sixfold stimulation of ErbB2 as a result of transactivation. Statistical analyses by a two sample student's ttest revealed differential ErbB1 and ErbB2 activation by EGF $(\mathrm{P}<.018)$ but no significant difference in their activations by radiation $(\mathrm{P}<.817)$. This data demonstrated the distinctly different 
mechanisms of ErbB receptor activation after the exposure of cells to GF's or radiation. Analogous responses were derived for T47D cells (data presented in Figure 2-4). Quantitatively similar stimulations of both of ErbB1 and ErbB2 were observed after radiation relative to the GF-induced hierarchic receptor responses driven by the specificities of GF-ErbB receptor interactions. The role of ErbB1 and ErbB2 function on receptor activation by GF and radiation

We next examined the relative role of ErbB receptors on GF- and radiation-induced receptor interactions. These studies were conducted with MDA cells in which the functions of ErbB1 and ErbB2 were selectively inhibited by the tyrphostins AG1478 and AG825, respectively $(17,25,42)$. Our previous studies $(39,41)$ were confirmed by the results in Figure $6 \mathrm{~b}$ demonstrating that AG1478 completely inhibited basal, ligand- and radiation-induced activation of ErbB 1 . Independent control experiments affirmed that AG1478 did not affect basal ErbB2 phosphorylation as predicted by the $>30.000$-fold difference in IC50 values for ErbB1 and ErbB2 (data not shown, 25,42). In contrast inhibition of ErbB2 function by AG825 eliminated ErbB2 Tyr phosphorylation (Figure 6c) but increased by an average 2.4-fold basal ErbB1 Tyr phosphorylation (Figure 6a, d; P<.05). While the GF- and radiation-induced ErbBl Tyr phosphorylation levels were also always higher under conditions of ErbB2 inhibition, these enhancements did not reach statistical significance (Figure 6d). These results were consistent with the relative inhibitor selectivity of AG825 for ErbB2. Furthermore, these results demonstrated that inhibiting ErbB2 resulted in a compensatory activation of ErbB1 suggesting a possible negative modulating role for ErbB2 on ErbB1 function (22).

\section{II.1.3.5. ErbB RTK function and MAPK responses in MDA and T47D cells}




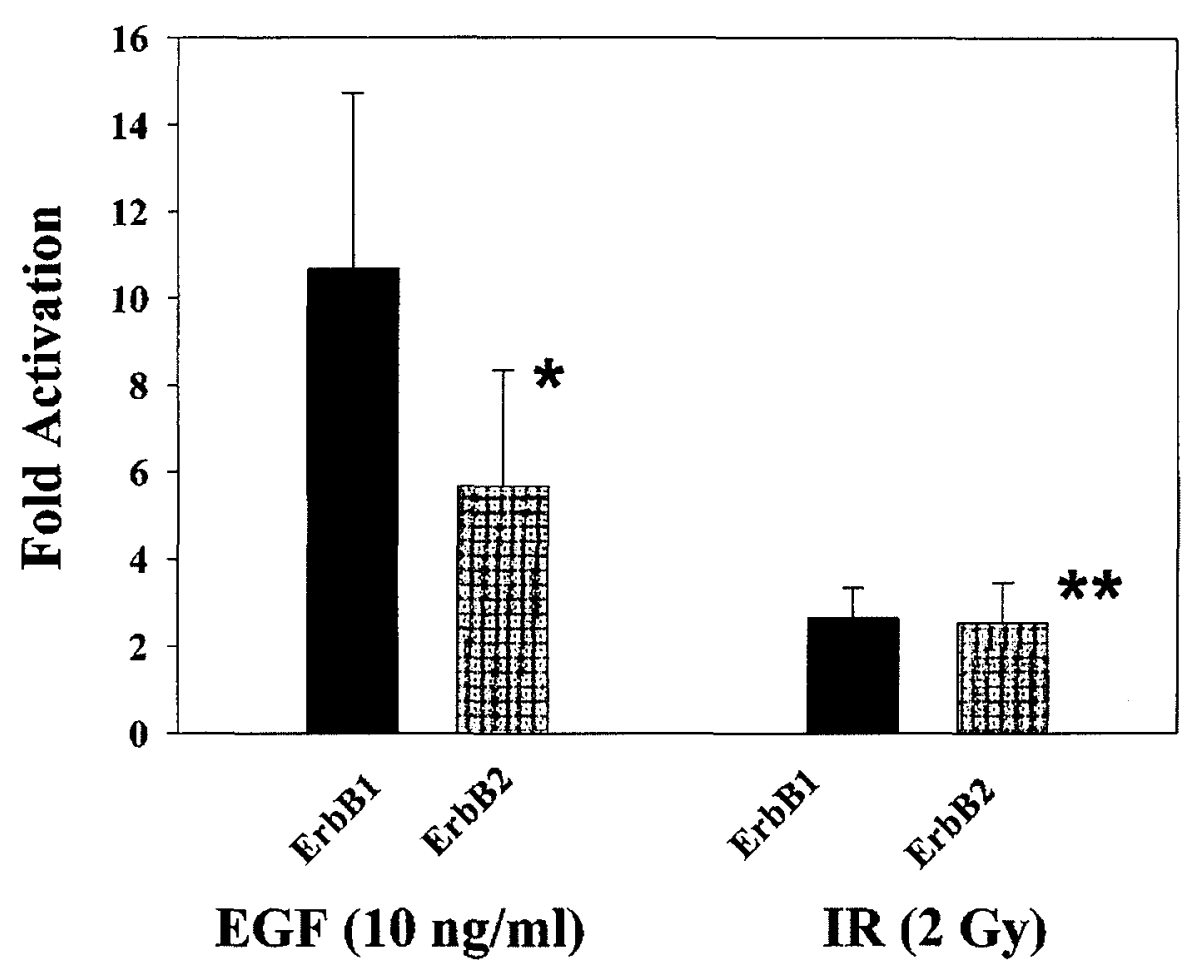

Figure 5

Figure II.1.5. Comparison of ErbB2 activation by EGF and radiation. Results from seven independent experiments were averaged and presented as the mean \pm s.d. Activation of ErbBI (dark bars) and ErbB2 (shaded bars) was monitored as tyrosine phosphorylation normalized with respect to untreated controls. Experimental treatments were: a 5 min exposure to $10 \mathrm{ng} / \mathrm{ml}$ EGF or at peak phosphorylation after a $2 \mathrm{~Gy}$ radiation exposure. Differential activations of ErbBI and ErbB2 by EGF and radiation were statistically evaluated by a two sample siudent's t-test. Statistical significance was established for differential ErbB1 and ErbB2 activation by EGF $\left({ }^{*} P<0.018\right)$. There was no statistically significant difference in ErbBI and ErbB2 activation by radiation $(* * P<0.817)$.

In defining the biological importance of ErbBl and ErbB2 function on radiation-induced cellular responses the receptor activation profiles have been linked to differences in downstream signals. As a downstream target, we selected MAPK, a previously identified mediator of cytoprotective responses after radiation (see below; 32). We have demonstrated that substantial differences in ErbBl activation levels obtained after EGF and radiation exposure of cells nonetheless result in similar stimulations of MAPK (32).

The conditions for these studies were identical to those used in the experiments of Figure 6 for analysis ErbB Tyr phosphorylation. Radiation and EGF induced significant 1.6- and threefold 
activations of MAPK, a phasic response that was maximal at about $5 \mathrm{~min}$ and returned to basal levels within $10 \mathrm{~min}$ (Figure 7a,b). This initial activation was followed by a more protracted increase in MAPK activity after exposure of MDA cells to EGF (Figure 7b; 32). Importantly, both the EGF and radiation responses are completely eliminated by inhibiting ErbBI function with AG1478 (Figure 7a,b). Almost identical, but quantitatively more pronounced responses were observed for T47D cells after treatment with HRG and radiation, including the elimination of these responses by pre-treatment of cells with AG1478 (Figure 8a,b). This data further support the conclusion that ErbB1 and ErbB4 play analogous roles in MDA and T47D cells in respect to MAPK activation. 


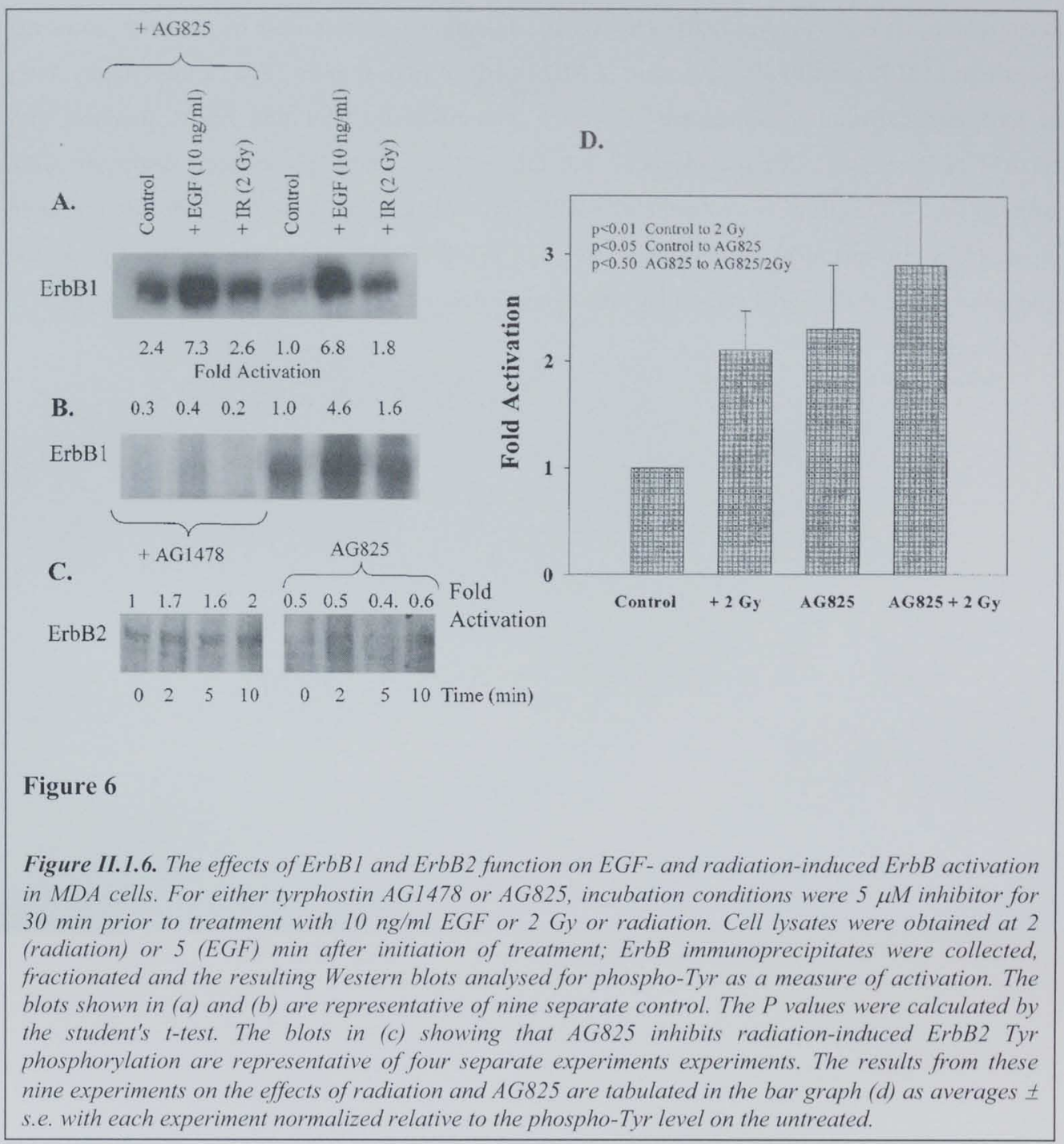

Inhibition of ErbB2 function with AG825 prior to GF or radiation exposure consistently elevated basal MAPK activity and caused a large enhancement of the ErbB1-dependent stimulation of MAPK (Figures 7 and 8). Furthermore, the MAPK response profiles after radiation and GF exposure were significantly altered. EGF-induced phasic ErbBl activation was converted by AG825 into a sustained five-fold activation. In the case of radiation, the $5 \mathrm{~min}$ phasic activation was converted into a broad three-fold activation lasting for $60 \mathrm{~min}$. Qualitatively similar modifications were observed for T47D cells, in which inhibition of ErbB2 enhanced the ErbB4-dependent MAPK 
activity. These findings were also consistent with enhanced ErbBI activation levels observed after AG825 treatment of MDA cells (Figure 6).

\section{II.1.4. Discussion}

The results presented herein underscore previous findings from our laboratory identifying the critical role of plasma membrane-associated ErbB RTKs in the radiation response of autocrine growth-regulated carcinoma cells. We now demonstrate that the ErbB expression profile of carcinoma cells can determine the interactions between different ErbB RTKs. In addition, the data provides the first evidence for distinct ErbB response profiles of cells after exposure to GFs or radiation. GFs induce a hierarchic activation initiated by homodimerization/activation of those ErbB species primarily interacting with given GF. Secondary activation of other ErbB receptors occurs through heterodimerization. In contrast, ionizing radiation activates indiscriminately all ErbB molecules expressed by a given carcinoma cell, thus placing greater importance on the relative expression levels of ErbB receptors. Thus, the GF response is driven by ErbB expression and receptor-ligand specificities whereas the radiation response may primarily be determined by cellular ErbB expression profiles. The importance of these differences in ErbB receptor interaction responses is further emphasized by distinct MAPK response profiles after exposure of cells to GFs or radiation $(28,32)$. 


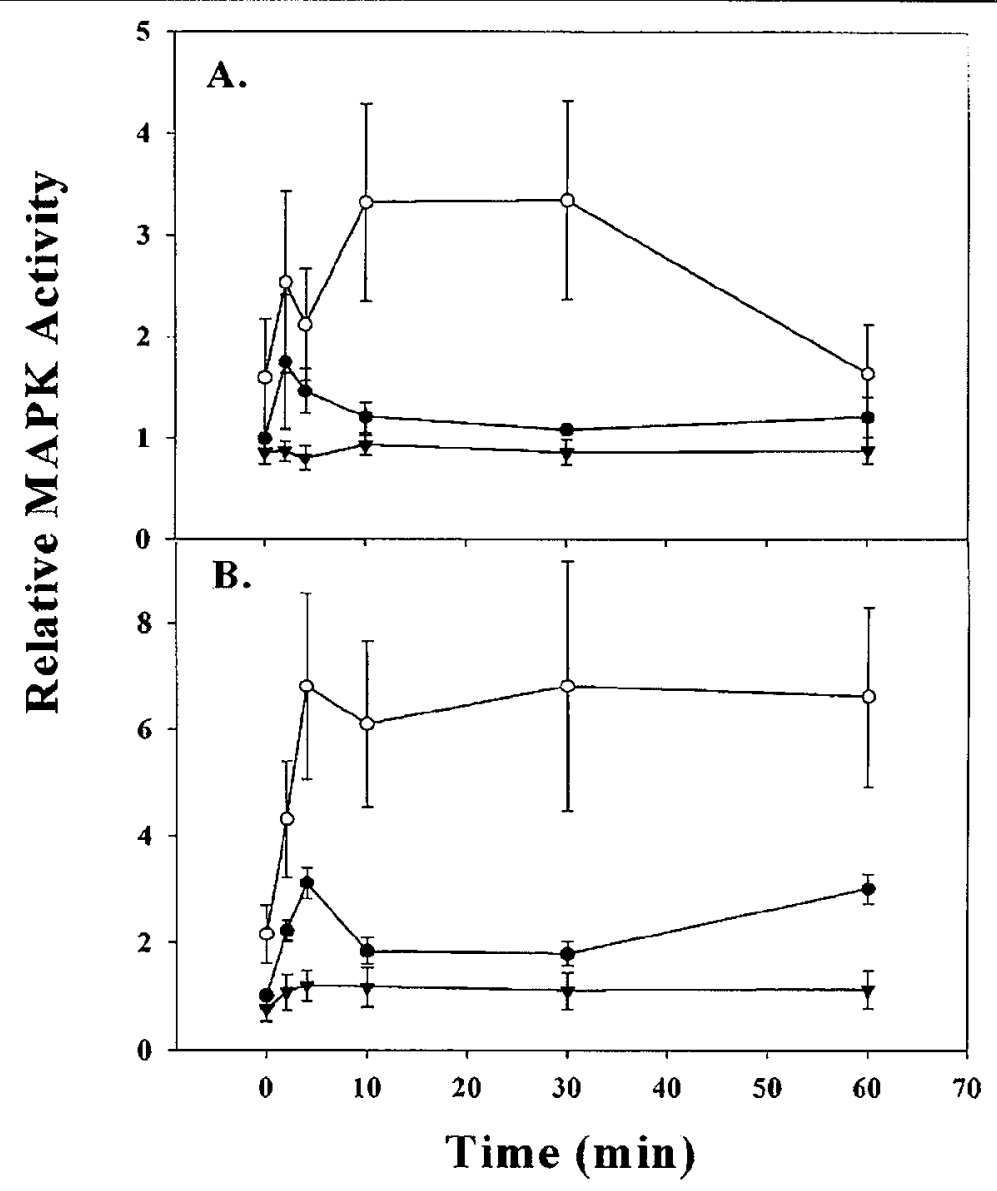

Figure 7

Figure 11.1.7. ErbB RTK function and MAPK responses in MDA cells. The same experimental protocol was used as described in the legend to Figure 5 except that at the indicated times cell lysates were prepared and MAPK immunoprecipitates obtained for immune complex assays of MAPK activity. (a)

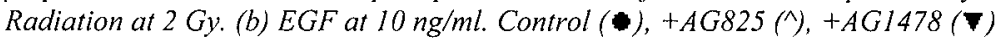

The apparent indiscriminate activation of different ErbB molecules by radiation raises questions concerning the underlying activation mechanism and whether alternative, ErbB- independent pathways exist for radiation-induced downstream signaling. One likely activation mechanism we 
are investigating involves inhibition of protein Tyr phosphatases $(37,38)$. Previous studies have demonstrated that reactive oxygen (e.g. $\mathrm{H}_{2} \mathrm{O}_{2}$ ) oxidizes a Cys in the active sites of most all protein Tyr phosphatases, thereby inhibiting phosphatase activity. One consequence of this inhibition is the apparent stimulation of ErbBl as indicated by its enhanced Tyr phosphorylation (e.g. 6,13). Such a mechanism also applies to other Tyr kinases whose activities are counter-balanced by apposing Tyr phosphatases. As a consequence in cells not expressing ErbB receptors, radiation-induced MAPK

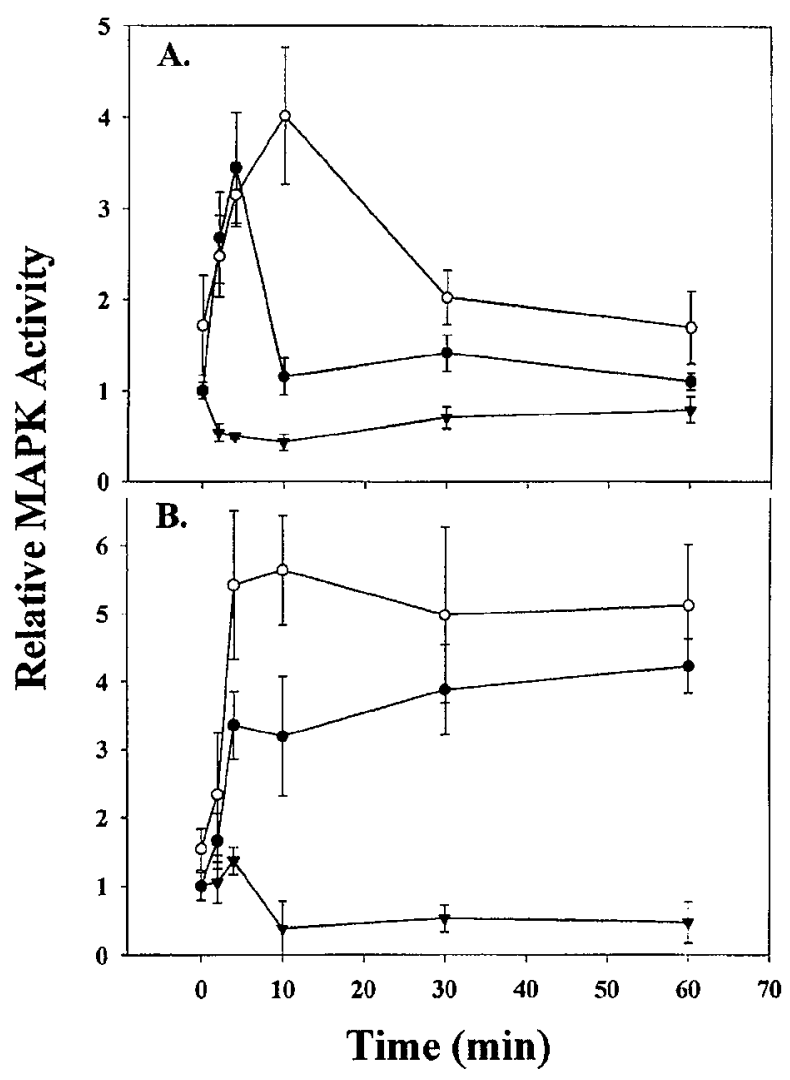

\section{Figure 8}

Figure II.1.8. Erbb RTK function and MAPK responses in T47D Cells. The same experimental protocol was used as described in the legend in Figure 6. (a) Radiation at $2 \mathrm{~Gy}$. (b) $\mathrm{HRG}$ at $10 \mathrm{ng} / \mathrm{ml}$. Control (-), $+A G 825\left({ }^{\wedge}\right),+A G 1478(\mathbf{\nabla})$

activation may still be observed but involving some other Tyr Kinase-Tyr phosphatase couple. It should also be noted that the catalytic activity of the dual specificity protein phosphatase, MKP-1, that dephosphorylates and inhibits MAPK, is also dependent on an active site Cys (9). 
While the ErbB protein expression and activation data are important for the studies presented, certain caveats have to be applied to their interpretation. The evaluation of different ErbB protein expression levels within a given cell line using immunochemical techniques may not reflect precisely the actual expression levels because of $\mathrm{mAb}$ characteristics and other parameters that influence the absolute signal used to quantify the protein. Therefore, comparing expression levels of different ErbB receptors in a given cell line is less reliable than the relative quantitation of the same ErbB receptor in different cell lines. Another consideration is that the relative expression levels of ErbB proteins may depend on culture conditions and the duration of continuous culture $(22,41)$. Despite these caveats our findings support the concept that in autocrine growth regulated carcinoma cells at least one of the ErbB receptors with GF binding specificity and an active kinase domain, such as ErbBl or ErbB4, are dominantly expressed. For the quantitative evaluation of the relative activation levels of ErbB receptors, as assessed by Tyr phosphorylation, methodological details similar to those described above have to be kept in mind. Thus, most reliable are the increases in Tyr phosphorylation of a given ErbB molecule in the same cell after treatment with GF or radiation.

We have concentrated in this study on the relative interactions of ErbB1 or ErbB4 with ErbB2. The experimental approach is to selectively inhibit the catalytic function of the ErbB molecules and to examine effects on downstream targets. The results establish important links between different ErbB receptor interactions and downstream responses that affect cellular radiosensitivity, such as MAPK $(1,28,37)$. Tryphostins with specificities for the different ErbB receptors were used for reasons of experimental consistency and flexibility in manipulating ErbB receptor functions. Although the use of chemical inhibitors is not without problems, our previous studies demonstrated that the effects of $\mathrm{AG} 1478$ on ErbBl and its downstream effectors are identical to those observed after expression of the dominant negative EGFR-CD533 (11,32,33). Furthermore, the experimental analyses (Figure 6) on the relative effects of the tyrphostins on ErbB1 and ErbB2 Tyr phosphorylation are consistent with the selectivities of AG1478 for ErbB1 and AG825 for ErbB2.

It has been proposed that the constitutively active ErbB2 has a positive modulating effect on other ErbB receptors $(3,4,14)$. However, limited information exists regarding the details of such response modulation (22), and the results presented here suggest more complex mechanisms. Indeed our observation of enhanced Tyr phosphorylation of ErbB1 after inhibition of ErbB2 is the opposite to what one would predict if ErbB2 acts as a heterodimerization partner to enhance signals of GFbinding ErbB receptors, such as ErbB1 or ErbB4. One reason for the difference in findings may be that previous studies concentrated on intrinsic growth regulatory events whereas our studies 
examine immediate responses to the extrinsically added GF or ionizing radiation. Our data suggests that, in these situations, the inhibition or ErbB2 function and its elimination as a dimerization partner leads to enhanced activation of ErbB1, most likely due to preferred homodimerization. The biological consequence of this response is exemplified by a marked modification of the MAPK response in MDA cells leading to an amplification and prolongation of the MAPK activation. The analogous roles of ErbB1 and ErbB4 in MDA and T47D cells, respectively, are supported by similar modifications of the radiation and HRG responses under conditions of ErbB4 and ErbB2 inhibition in T47D cells. The data also supports the dominant role of ErbB1 and ErbB4 receptor activation in signals along the MAPK pathway (32).

Since the ErbBl catalytic function is required for radiation-induced MAPK activation (39), we expected that treatment of cells with AG825 would also enhance radiation-stimulated ErbB1 Tyr phosphorylation. Instead, AG825 increased the basal ErbB1 Tyr phosphorylation without significant enhancement in the radiation or GF components. One explanation for this apparent discrepancy in the effects of AG825 on radiation-stimulated ErbB1 and MAPK activities is that the global enhancement in phosphorylation of the five major ErbBl autophosphorylation sites can obscure changes in the phosphorylation state of the yet unidentified site required for ErbB1dependent MAPK activation (e.g. 8). Alternatively, ErbB1-dependent Ras/MAPK signaling can occur by mechanisms not requiring autophosphorylation as shown for ErbB1 lacking the five major Tyr phosphorylation sites $(20,26,35)$ and for c-Src sensitive sites of ErbBI (8). There is evidence that this auxiliary pathway is dependent upon interactions between ErbB1 and ErbB2 (35). These mechanisms of relative enhancement from the membrane associated receptor(s) to the cytoplasmic MAPK are currently being investigated in more detail.

The pleiotropic effects of MAPK on nuclear regulatory events emphasize the relative importance of upstream regulatory functions of ErbB RTKs. The MAPK pathway is known to modulate the phosphorylation and DNA binding abilities of several downstream transcription factors, including members of the Ets- (Dent et al., unpublished) and AP- 1 transcription factor families $(15,44)$. Thus, it is reasonable to hypothesize that inhibition of ErbB2 will, after radiation exposure, increase transcription of Ets- and AP-1-responsive genes and, secondarily, of important cell cycle regulators, such as the cyclin kinase inhibitor $\mathrm{p} 21^{\mathrm{Cip}-1 / \mathrm{WAF} 1}(7,29)$. In addition, the protein expression levels of multiple transcription factors have also been suggested to depend on MAPK signaling $(5,10,40)$. For example, we recently demonstrated that inhibition of MAPK in MDA cells rapidly reduced the protein levels of c-Jun (32). 
In summary, this manuscript describes for the first time that ErbB RTK expression profiles of human carcinoma cells can influence ErbB receptor activation in response to ionizing radiation and GF. The distinctly different responses of ErbB receptors translate into distinct MAPK activation patterns that may have important consequences for cellular responses to ligands or radiation. Since ErbB RTKs through MAPK mediate an important cytoprotective response to radiation $(11,32,39)$, a more detailed understanding of the relative roles of different ErbB molecules in cellular responses to radiation is important for targeted and mechanism-based therapeutic intervention. 


\section{II.1.5. References}

1. Abbott D, Holt JG. (1999). J. Biol. Chem. 274, 2732-2742.

2. Akimoto T, Hunter NR, Buchmiller L, Mason K, Ang K, Milas L. (1999). Clin. Cancer Res. 5, 28842890.

3. Alimandi M, Romano A, Curia MC, Muraro R, Fedi P, Aaronson SA, Di Fiore PP, Kraus M. (1995). Oncogene 10, 1813-1821.

4. Alimandi M, Wang LM, Bottaro D, Lee CC, Kuo A, Frankel M, Fedi P, Tang C, Lippman M, Pierce JH. (1997). EMBO J. 16, 5608-5617.

5. Aubert JS, Dessolin S, Belmonte N, Li M, McKenzie FR, Staccini L, Villageois P, Barhanin B, Vernallis A, Smith AG, Ailhaud G, Dani C. (1999). J. Biol. Chem. 274, 24965-24972.

6. Bae YS, Kang SW, Seo MS, Baines IC, Tekle E, Chock PB, Rhee SG. (1997). J. Biol. Chem. 272, 217-221.

7. Beier F, Taylor AC, LuValle P. (1999). J. Biol. Chem. 274, 30273-30279.

8. Biscardi JS, Maa MC, Tice DA, Cox ME, Leu TH, Parson SJ. (1999). J. Biol. Chem. 274, 8335-8343.

9. Brondello JM, McKensie FR, Sun H, Tonks NK, Poyssequr J. (1995). Oncogene 10, 1895-1904.

10. Chen BK, Kung HC, Tsai TY, Chang WC. (2000). Mol. Pharmacol. 57, 153-161.

11. Contessa JN, Reardon DB, Todd D, Dent P, Mikkelsen RB, Valerie K, Bowers GD, Schmidt-Ullrich RK. (1999). Clin. Cancer. Res. 5, 405-411.

12. Dent P, Reardon DB, Park JS, Bowers GD, Logsodon C, Valerie K, Schmidt-Ullrich RK. (1999). Mol. Biol. Cell. 10, 2493-2506.

13. Denu JM, Tanner KG. (1998). Biochemistry 37, 5633-5642.

14. Earp HS, Dawson TL, Li X, Yu H. (1995). Breast Cancer Res. Treat. 35, 115-132.

15. Fowles LF, Martin ML, Nelson L, Stacey KJ, Redd D, Clark YM, Nagamine Y, McMahon M, Hume DA, Ostrowski MC. (1998). Mol. Cell. Biol. 18, 5148-5156.

16. Frederick L, Wan XY, Eley G, James CD. (2000). Cancer Res. 60, 1383-1387.

17. Fry DW, Kraker AJ, McMichael A, Ambroso LA, Nelson JM, Leopold WR, Connors RW, Bridges R. (1994). Science 265, 1093-1095.

18. Gamett DC, Greene T, Wagreich AR, Kim HH, Koland JG, Cerione RA. (1995). Biol. Chem. 270, 19022-19027.

19. Gamett DC, Pearson G, Cerione RA, Friedberg I. (1997). J. Biol. Chem. 272, 12052-12056.

20. Gotoh M, Toyoda M, Shibuya M. (1997). Mol. Cell. Biol. 17, 1824-1831.

21. Graus-Porta D, Beerli RR, Daly JM, Hynes NE. (1997). EMBO J. 16, 1647-1655.

22. Gulliford TJ, Huang GC, Ouyang X, Epstein RJ. (1997). Oncogene 15, 2219-2223.

23. Huang GC, Ouyang X, Epstein RJ. (1998). Biochem. J. 331, 113-119.

24. Kern FG, McLeskey SW, Khang L. (1994). Breast Cancer Res. Treat. 31, 153-165.

25. Levitzki A, Gazit A. (1995). Science 267, 1782-1788.

26. Li N, Schlessinger J, Margolis B. (1994). Oncogene 9, 3457-3465.

27. O'Rourke DM, Kao GD, Singh N, Park BW, Muschel RJ, Wu CJ, Greene MI. (1998). Proc. Natl. Acad. Sci. U.S.A. 95, 10842-10847.

28. Park JS, Carter S, Reardon DB, Schmidt-Ullich RK, Dent P, Fisher PB. (1999). Mol. Cell. Biol. 10, $423 \bar{i}-4246$.

29. Park JS, Boyer S, Mitchell K, Gilfor D, Birrer M, Darlington G, El-Deiry W, Firestone GL, Munger K, Band V, Fisher PB, Dent P. (2000). J. Biol. Chem. 275, 18-28.

30. Plowman GD, Culouscou JM, Whitney GS, Green JM, Carlton GW, Foy L, Neubauer MG, Shoyab M. (1993). Proc. Natl. Acad. Sci. USA 90, 1746-1750.

31. Qian W, LeVea CM, Freeman JK, Dougall WC, Greene MI. (1994). Proc. Natl. Acad. Sci. USA 91, $1500-1504$.

32. Reardon DB, Contessa JN, Mikkelsen RB, Valerie K, Amir C, Dent P, Schmidt-U1lrich RK. (1999). Oncogene $18,4756-4766$.

33. Redemann N, Holzmann B, Reuden TV, Wagner EF, Schlessinger J, Ullrich A. (1992). Mol. Cell. Biol. 12, 491-498.

34. Riese DJ, Stern DF. (1998). Bioessays 20, 4i-48.

35. Sasaoka T, Langlois WJ, Bai F, Rose DW, Leitner JW, Decker SJ, Saltiel A, Gill GN, Kobayayashi M, Drasnin B, Olefsky JM. (1996). J. Biol. Chem. 271, 8338̈-8344.

36. Schmidt-Ullrich R, Valerie K, Fogleman PB, Walters J. (1996). Radiation Res. 145, 81-85. 
37. Schmidt-Ullrich R, Contessa JN, Dent P, Mikkelsen RB, Valerie K, Reardon DB, Bowers G, Lin PS. (1999). Radiat. Oncol. Invest. 7, 32i -330.

38. Schmidt-Ullrich R, Dent P, Grant S, Mikkelsen RB, Valerie K. (2000). Radiat. Res. 153, 245-257.

39. Schmidt-Ullrich R, Mikkelsen RB, Dent P, Todd D, Valerie K, Kavanagh B, Contessa J, Rorrer K, Chen P. (1997). Oncogene 15, 1191-1197.

40. Sears R, DeGregori LG, Nevins JR. (1993). Mol. Cell. Biol. 3, 169-179.

41. Todd DG, Mikkelsen RB, Rorrer WK, Valerie K, Schmidt-Ullrich RK. (1999). J. Rec. Signal Trans. Res. 19, 885-908.

42. Tsai C, Levitzki A, Wu LH, Chang KT, Cheng CC, Gazit A, Perng RP. (1996). Cancer Res. 56, 10681074.

43. Verheij M, Bose R, Lin XH, Yao B, Jarvis WD, Grant S, Birrer MJ, Szabo E, Zon LI, Kyriakis JM, Haimovitz-Friedman A, Fuks Z, Kolesnick RN. (1996). Nature 380, 75-79.

44. Wang Y, Prywes R. (2000). Oncogene 19, 1379-1385. 


\section{Chapter II}

II.2. Adenovirus- mediated overexpression of dominant negative epidermal growth factor receptor- $\mathrm{CD533}$ as a gene therapeutic approach radiosensitizes human carcinoma and malignant glioma cells

Published in: Int J Rad Biol Phys. 51: 775-784, 2001 (IF = 3.33)

Guido Lammering, Peck-Sun Lin, Joseph N. Contessa, Jaime L. Hampton, Kristoffer Valerie and Rupert K. Schmidt-Ullrich 


\section{Summary}

Purpose: Epidermal growth factor receptor (EGFR) and other members of the ErbB family of receptor tyrosine kinases (RTK) mediate autocrine growth regulation in a wide spectrum of human tumor cells. We have previously demonstrated that in stably transfected mammary carcinoma cells a dominant negative (DN) mutant of EGFR, EGFR-CD533 is a potent inhibitor of EGFR and its cytoprotective signaling after exposure to ionizing radiation. In the present study, we further investigate the capacity of a genetic approach, using replication-incompetent adenovirus (Ad)mediated transfer of EGFR-CD533 (Ad-EGFR-CD533), to enhance the radiosensitivity in vitro of four cell lines representative of three major cancer phenotypes.

Methods and Materials: The cell lines MDA-MB-231 and T-47D mammary carcinoma, A-431 squamous carcinoma, and U-373 MG malignant glioma cells were used. The ErbB expression profiles and the EGFR tyrosine phosphorylation (Tyr-P) levels following irradiation were quantified by Western blotting. The relative radiosensitivities of tumor cells were assessed by standard colony formation assays after infection with control vector (Ad-LacZ) or Ad-EGFR-CD533.

Results: The expression profiles demonstrated varying levels of EGFR, ErbB2, ErbB3, and ErbB4 expression. The overexpression of EGFR-CD533 after infection with Ad-EGFR-CD533 completely inhibited the radiation-induced stimulation of EGFR Tyr-P relative to the immediate 2.4- to 3.1-fold increases in EGFR Tyr-P in control infected cells (Ad-LacZ). Ad-EGFR-CD533-infected cells demonstrated significant $(\mathrm{p}<0.001)$ radiosensitization over a range of radiation doses $(1-8 \mathrm{~Gy})$, yielding dose-enhancement ratios (DER) between 1.4 and 1.7. This radiosensitization was maintained under conditions of repeated radiation exposures, using $3 \times 2$ Gy, yielding DERs of 1.6 and 1.7 for MDA-MB-231 and U-373 cells, respectively.

Conclusions: Overexpression of EGFR-CD533 significantly sensitizes human carcinoma and glioma cells to single and repeated radiation exposures irrespective of their ErbB expression levels. Therefore, transduction of human tumor cells with EGFR-CD533 holds promise as a gene therapeutic approach for the radiosensitization of neoplastic cells that are growth-regulated by EGFR or other ErbB receptors. 


\section{II.2.1. Introduction}

The epidermal growth factor receptor (EGFR) and other members of the ErbB growth factor receptor family are critically involved in the autocrine growth regulation of many malignant cells. This is partially reflected in the fact that EGFR is overexpressed in human tumor cells including carcinomas of the breast, prostate, lung, head and neck, and malignant gliomas ( $1-8)$. In addition, a number of mutated receptors have been identified and their functional abnormalities relative to the wild-type (WT) $170 \mathrm{kD}$ EGFR have been described ( $9-11)$. Increasing levels of EGFR or ErbB2 expression correlate with a more aggressive neoplastic phenotype and are linked to an adverse prognosis (12-15). Both preclinical experimental results and correlative clinical studies indicate that carcinoma cells with high EGFR expression levels exhibit less favorable responses to radiotherapy (16-18) and to chemotherapeutic agents $(19,20)$, findings that have stimulated research to target EGFR for novel therapeutic interventions.

Recently, we have identified some of the mechanisms underlying the EGFR-mediated radioresistance of tumor cells. EGFR is activated after exposure of cells to ionizing radiation in the 1-5 Gy dose range. This activation is currently indistinguishable from that induced by growth factors, such as epidermal growth factor (EGF) or transforming growth factor $\alpha$ (TGF $\alpha)(21,22)$. Similar to effects of growth factors, the radiation-induced EGFR activation leads to a proliferative response that includes the stimulation of the mitogen-activated protein kinase (MAPK) pathway (23). This activation of the pro-proliferative EGFR/MAPK cascade represents at least one mechanism underlying radiation-induced accelerated proliferation, which has been identified as a major cytoprotective response counteracting the cytotoxic effects of radiation (24- 26). This conclusion is supported by findings that inhibition of EGFR activation results in cellular radiosensitization (27-30). For reasons of specificity and broad applicability, we are examining the relative effectiveness of inhibiting EGFR activation through a genetic approach of overexpressing EGFR-CD533, a dominant negative (DN) variant of EGFR that lacks the entire cytoplasmic domain of 533 amino acids $(31,32)$. In previous studies, using stably transfected MDA-EGFR-CD533 mammary carcinoma cells we have identified two mechanisms contributing to the radiosensitization of tumor cells $(27,33)$. The first mechanism relates to disruption of the radiation-induced proliferation response in a repeated radiation exposure proliferation assay (27), and the second represents enhanced cytotoxicity that is quantified by single exposure radiation dose-response experiments (33).

In this report we examined the direct radiosensitization in more detail. Representative human tumor cell lines, expressing quantitatively and qualitatively different profiles of ErbB receptors, have been 
selected to examine the general applicability of our approach of overexpressing the DN-EGFRCD533 receptor for potential therapeutic radiosensitization. In line with the preclinical therapeutic questioning, we have used an adenoviral vector, Ad-EGFR-CD533, to express EGFR-CD533 in mammary and squamous carcinoma and malignant glioma cells. The study quantifies the extent of radiosensitization in vitro after single and repeated radiation exposures upon overexpression of EGFR-CD533 in tumor cell lines that express substantially different levels of EGFR and other ErbB receptors.

\section{II.2.2. Methods and Materials}

\section{II.2.2.1. Reagents}

Unless specified otherwise, all reagents were from Sigma Chemical Co. (St. Louis, MO). All electrophoresis reagents were from BioRad (Hercules, CA). The medium and the antibiotics were from GIBCO-BRL (Rockville, MD), and fetal bovine serum (FBS) was from Intergen (Purchase, NY). Monoclonal antibodies (mAb) against the EGFR (ErbB1), ErbB2, -3 , and -4 proteins were from Neo Markers (Fremont, $\mathrm{CA}$ ). The $\mathrm{mAb}$ to immunoprecipitate EGFR and the anti-Tyr-P mAb were from Oncogene Science (Cambridge, MA)

\section{II.2.2.2. Cells}

The human mammary carcinoma cell lines MDA-MB- 231 and T-47D, the human squamous carcinoma cell line A-431, and the human glioma cell line U-373 MG were obtained through the American Type Tissue Collection (ATTC; Rockville, MD). The MDA-TR15-EGFR-CD533 cell line, referred to as MDA-EGFR-CD533, was developed in our laboratory through stable transfection of MDA-MB- 231 cells with EGFR-CD533 under control of a doxycycline (Dox)inducible promoter (27). The cell lines MDA-EGFRCD533, MDA-MB-231, and A-431 were maintained in RPMI 1640 medium containing 5\% FBS (RPMI/5FBS) and antibiotics (penicillin/streptomycin). T-47D cells required RPMI/10FBS, and U-373 MG cells were maintained in Eagle's minimal essential medium containing 10\% FBS (MEM $\alpha / 10 \mathrm{FBS}$ ). Before irradiation, cells were maintained in medium, containing $0.5 \% \mathrm{FBS}$, for $16 \mathrm{~h}$ as previously described $(27,34)$. All cell lines were tested monthly to exclude mycoplasma contamination by polymerase chain reaction $(\mathrm{PCR})$.

\section{II.2.2.3. Recombinant adenoviruses}

Replication-incompetent adenovirus (Ad) was produced as previously described $(35,36)$. The EGFR-CD533 complementary DNA (cDNA) $(31,32)$, lacking the 533 COOHterminal amino acids, 
was kindly provided by A. Ullrich (Max-Planck-Institute for Biochemistry, Martinsried, Germany). Ad-EGFR-CD533 or the control vector Ad-LacZ, expressing the bacterial lacZ reporter gene, was produced in HEK 293 cells and purified by established techniques $(36,37)$. Titration by standard plaque assay yielded typical titers of $2 \times 1011$ plaque-forming units per milliliter (pfu/mL). Cell lines were infected with Ad-EGFR-CD533 or Ad- LacZ viral stocks diluted with phosphatebuffered saline (PBS) by adding adenoviral preparations to cell monolayers ( $60-\mathrm{mm}$ dish) and by placing dishes on a rocker with gentle continuous agitation in a tissue culture incubator for $4 \mathrm{~h}$ at $37^{\circ} \mathrm{C}$. After medium change, infection efficiency was quantified $48 \mathrm{~h}$ later for $\mathrm{Ad}-\mathrm{Lac} Z$ by counting $\beta$-galactosidase positive cells from a total of 500 cells $(37,38)$. The multiplicity of infection (MOI) was optimized for maximum infection and cellular toxicity not to exceed a $30 \%$ reduction in colony formation efficiency (CFE); the only exception was the T-47D cell line for which a $\sim 50 \%$ loss in CFE had to be accepted.

\section{II.2.2.4. Western blotting}

Western blotting was performed as described (27); briefly, frozen cells were lysed in ice-cold lysis buffer and by repeated passage through 20-gauge needles. The protein concentration in supernatants after centrifugation at $14,000 \mathrm{x} g$ for $10 \mathrm{~min}$ was quantified using a BIO-RAD protein assay kit (Bio-Rad Labs, Richmond, CA). Aliquots of protein, 200x g of cell lysate, were subjected to Western analysis for ErbB1, ErbB2, ErbB3, ErbB4, and EGFRCD533. After electrophoresis on 6\% sodium dodecyl sulfate (SDS)-polyacrylamide gels, proteins were transferred electrophoretically onto nitrocellulose membranes (BioRad, Hercules, CA). The membranes were incubated with antiEGFR mAb, anti-ErbB2 $\mathrm{mAb}$, anti-ErbB3 $\mathrm{mAb}$, or anti-ErbB4 $\mathrm{mAb}$, followed by incubation with peroxidase-conjugated secondary anti-mouse $\mathrm{mAb}$. For visualization, bands were developed with the CDP-Star kit (Tropix, Inc., Bedford, MA).

\section{II.2.2.5. EGFR Tyr-P after irradiation}

Cells were seeded at a density of $5-10 \%$ in $60-\mathrm{mm}$ dishes and cultured for 5 days. On Day 3 , cells were infected with Ad-EGFR-CD533 or AdLacZ over a range of 1-100 MOI to quantify the transduction efficiency and cytotoxicity, as defined by loss of CFE, for each of the cell lines. After equilibration of cells in RPMI/0.5FBS or MEM $\alpha / 0.5 \mathrm{FBS}$ media for 16 h before irradiation, cells were exposed on Day 5 to a single dose of $2 \mathrm{~Gy}$ at a dose rate of $1.8 \mathrm{~Gy} / \mathrm{min}$ using a $60 \mathrm{Co}$ source. For time course experiments to assess radiation-induced EGFR, Tyr-P cells were rinsed at different times after irradiation in ice-cold PBS and then immediately frozen on dry ice. Immunoprecipitation of EGFR was performed as described (27) using cell lysates for each time point of the time course experiments. Equivalent amounts of protein, quantified by the BIO-RAD protein assay kit were 
incubated with anti-EGFR $\mathrm{mAb}$ at $4^{\circ} \mathrm{C}$ for $90 \mathrm{~min}$ followed by an incubation with protein $\mathrm{A}$ agarose (BioRad, Hercules, CA) for $45 \mathrm{~min}$. Agarose was recovered by centrifugation and immunoprecipitates were washed as described (27). Proteins were size fractionated and transferred electrophoretically onto nitrocellulose membranes, which were then probed with anti-Tyr-P mAb followed by incubation with peroxidase-conjugated secondary mAb. After developing with CDPStar kit, autoradiograms were quantified using Sigma Scan software (Jandel Scientific, San Rafael, CA) (22).

\section{II.2.2.6. Colony formation assay}

Forty-eight hours after infection with either Ad-EGFRCD533, Ad-LacZ, or mock infection, cells were irradiated with single doses of $1,2,3,4$, and $8 \mathrm{~Gy}$ and, after incubation for an additional $24 \mathrm{~h}$, harvested and plated for clonogenic survival. For repeated radiation exposure experiments, cells were exposed once daily to $2 \mathrm{~Gy}$ for 3 consecutive days beginning $48 \mathrm{~h}$ after infection or treatment of MDA-EGFRCD533 cells with Dox to induce maximum EGFR-CD533 expression. The number of cells was adjusted to generate 50-300 colonies per dish at each radiation dose and plated into 4well, 60-mm dishes. Cells were incubated under standard culture conditions for 12-17 days, depending on the cell line, stained with crystal violet, and colonies containing $>50$ cells were counted to determine the surviving fraction (39). The survival curves were fitted to the linearquadratic model (39).

\section{II.2.2.7. Statistical analysis}

All data are means \pm standard error of the mean (SEM), unless otherwise specified. Statistical comparisons between clonogenic survival curves were carried out by use of the F-test with the SAS software package (version 8.0; SAS Institute, Inc., Cary, NC). P values are two-sided and a $\mathrm{p}<0.05$ was considered to be statistically significant. Statistical comparisons for the clonogenic survival of T-47D cells were carried out with the Student's t test. The dose-enhancement ratios (DERs) were derived from the ratios of the dose for a survival of $37 \%$ (D37) in the different experimental groups and the ratios of the mean inactivation dose (D) in the different experimental groups (40) (Table 1).

\section{II.2.3. Results}

\section{II.2.3.1. Characterization of ErbB expression profiles}


The disruption of EGFR function through overexpression of EGFR-CD533 may have a potential

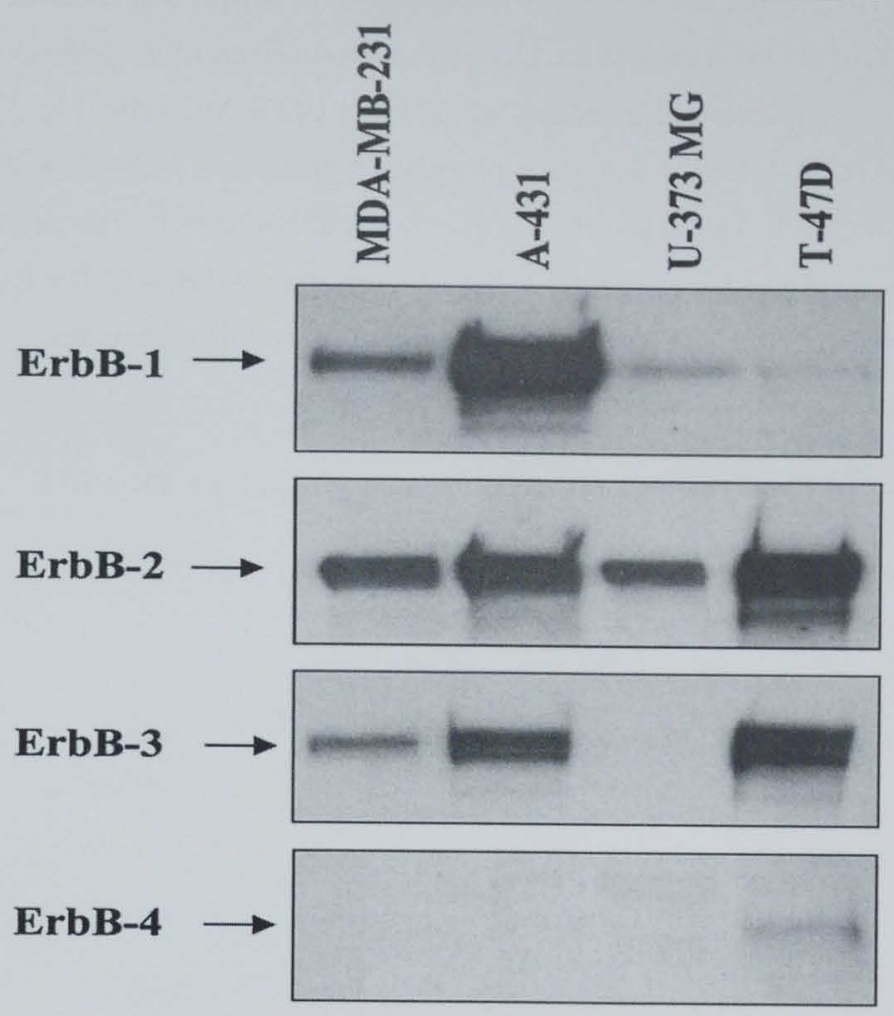

\section{Figure 1}

Figure 11.2.1: Relative expression levels of ErbB-1 (EGFR), ErbB-2, ErbB-3 and ErbB-4 in MDA-MB231, A-431, U-373 MG, and T-47D cells. Western blot analyses were performed on cell lysates for each cell line, after size fractionation by sodium dodecyl sulfate-polyacrylamide gel electrophoresis (SDS$P A G E)$, with a mAb specific for each ErbB molecule. Protein determination were used to standardize the amount of protein loaded to $0.2 \mathrm{mg}$.

therapeutic benefit in a variety of different neoplastic cell types. Therefore, studies of Ad-mediated EGFR-CD533 radiosensitization were performed in four representative human tumor cell lines expressing different ErbB profiles (41) and originating from three different tumor types. Because the relative expression of ErbB receptors has been shown to change depending on culture conditions (42), we have redefined the ErbB profiles for the experimental conditions and cell lines used in this report. 
Immunoblotting experiments with anti-EGFR $\mathrm{mAb}$ revealed a $170-\mathrm{kD}$ band of widely varied intensity in all samples (Fig. 1). As reported previously (41), the EGFR expression levels in the MDA-MB-231, T-47D, and the U-373 MG cell line were lower than in A-431 cells. Western blotting with anti-ErbB2 mAb showed the highest expression levels of the 185-kD ErbB2 protein in T-47D and A-431 cells, followed by MDA-MB-231 and U-373 MG cells (Fig. 1). ErbB3 protein was detectable in MDA-MB- 231 but was expressed at higher levels in A-431 and T-47D cells and absent in U-373 MG cells. ErbB4 protein was only found in T-47D cells. This cell line was selected for our studies because it expresses ErbB4 at higher levels than EGFR (41). The results demonstrate the widely varied expression levels of ErbB molecules in the cell lines examined.

II.2.3.2. EGFR-CD533 overexpression after infection with Ad- EGFR-CD33 


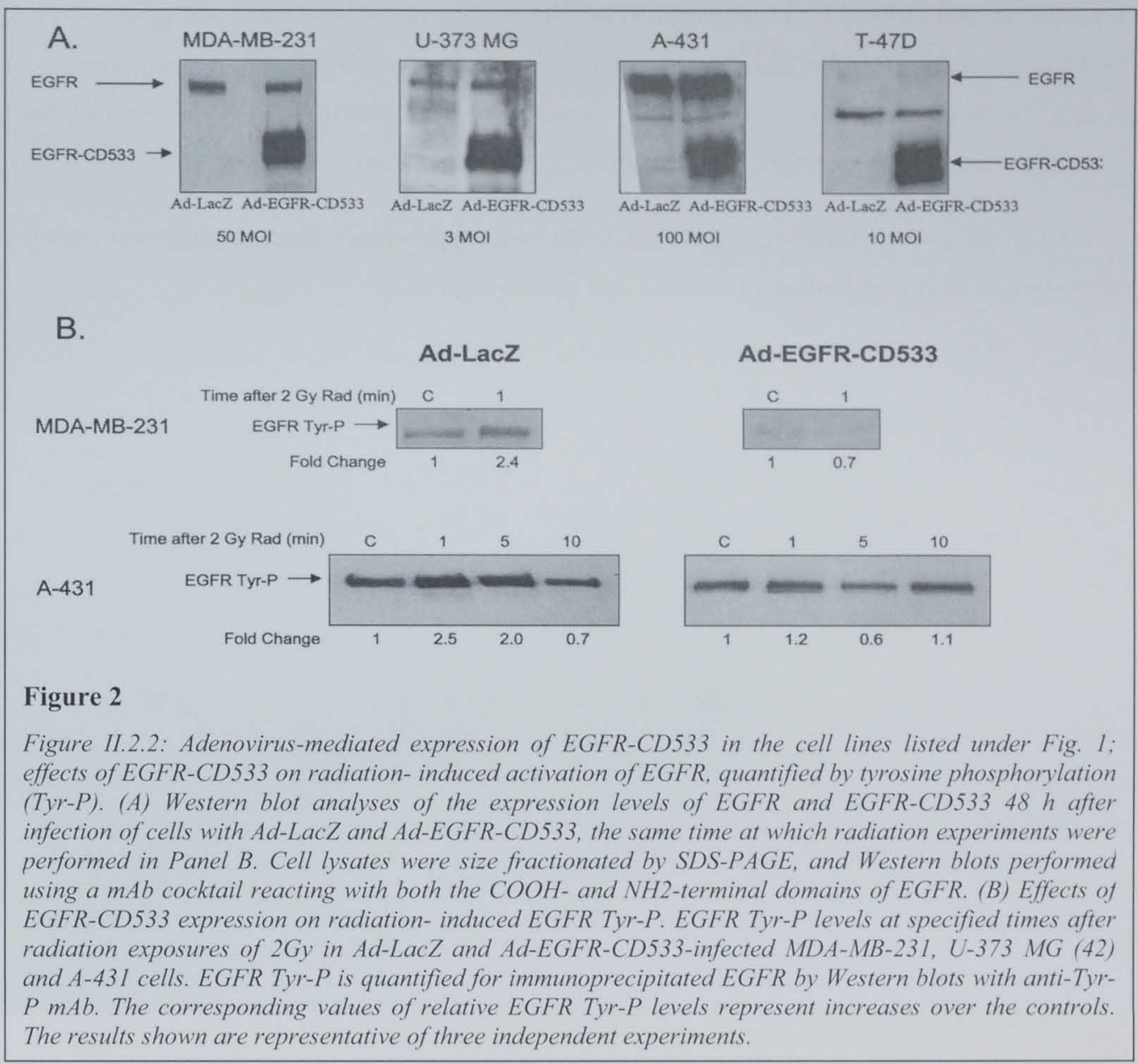

Adenoviral vectors are highly effective for the delivery of genes into human cell lines (35). The kinetics of EGFRCD533 expression after infections of cells with Ad-EGFR-CD533 were quantified by Western blots at different times after infection (data not shown). All radiation experiments were initiated $48 \mathrm{~h}$ after infection because EGFR-CD533 approached maximum expression levels at that time $(27,34)$.

Optimal infection conditions varied for the cells analyzed. We achieved $>80 \%$ infection rates with $50 \mathrm{MOI}$ for MDA-MB-231, $3 \mathrm{MOI}$ for U-373 MG, and $100 \mathrm{MOI}$ for A-431 associated with less than $30 \%$ cell toxicity in colony formation assays. The exception were T-47D cells that demonstrated $\mathrm{a}>50 \%$ toxicity at $10 \mathrm{MOI}$ (data not shown). However, the toxicity of Ad-EGFRCD533 was similar to the control vector Ad-LacZ. As defined by the relative intensity of protein staining, the expression levels of the EGFR-CD533 were substantially higher than the expression 
levels of the endogenous wild-type EGFR (Fig. 2A). For the duration of the experiments reported, EGFR-CD533 did not affect the expression levels of wild-type EGFR, as shown in comparison to Ad-LacZ-infected cells (Fig. 2A). Similar expression levels of EGFR-CD533 in the cell lines studied demonstrated the uniform effectiveness of Ad-mediated transduction.

II.2.3.3. Adenovirus-mediated EGFR-CD533 overexpression blocks radiation-induced activation of EGFR in human carcinoma and glioma cells 


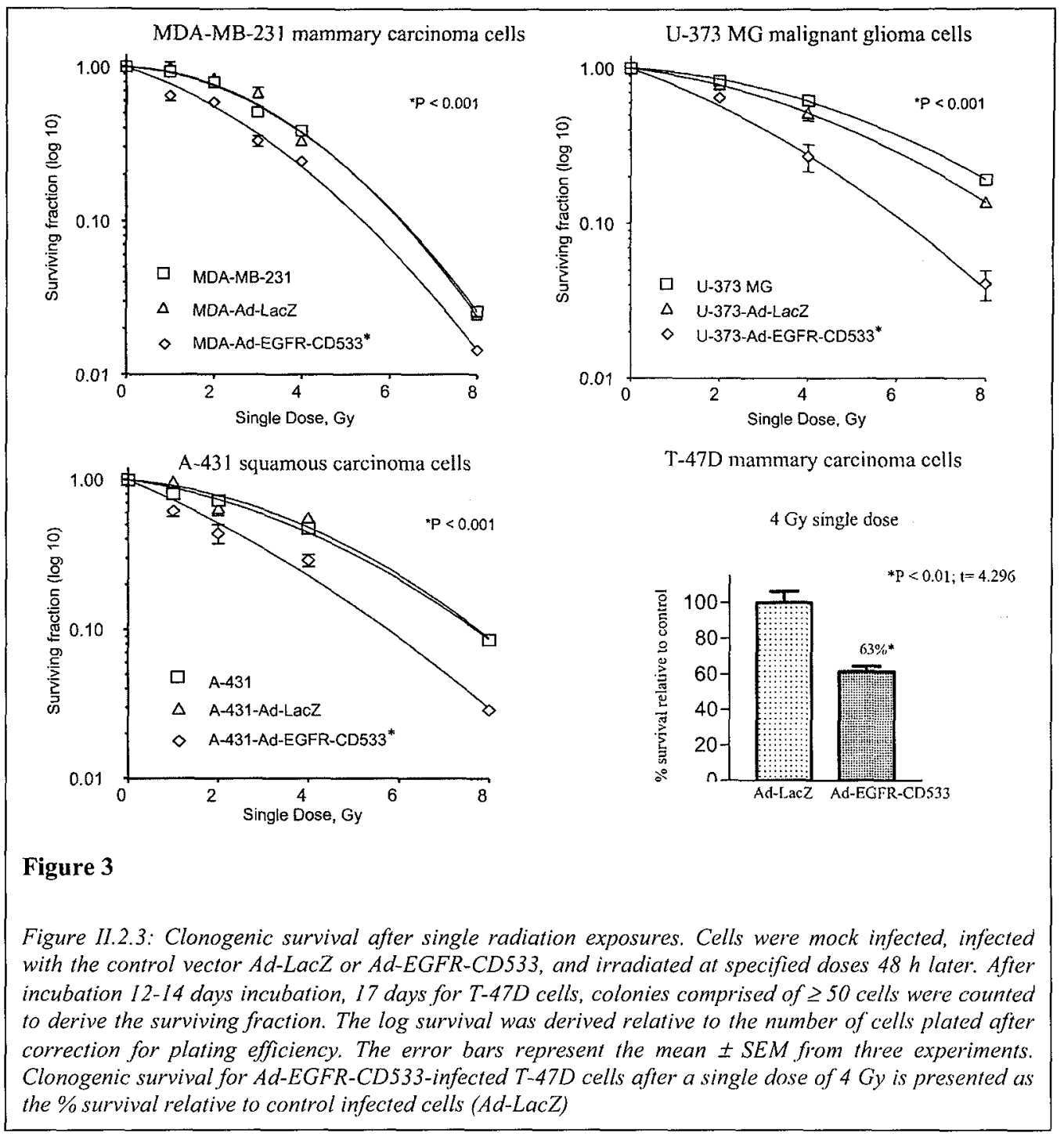

Previous studies established that overexpression of EGFR-CD533 disrupts EGFR function and autophosphorylation through protein-protein interactions $(27,34)$. To test whether overexpression of EGFR-CD533 affects the radiation- induced activation of EGFR in the carcinoma and glioma cells, we infected three different cell lines with markedly different EGFR expression with AdEGFR-CD533. The radiation-induced activation of EGFR was measured by the increase in EGFR Tyr-P levels. As shown in Fig. 2B, infection with the control Ad-LacZ did not affect the radiation- 


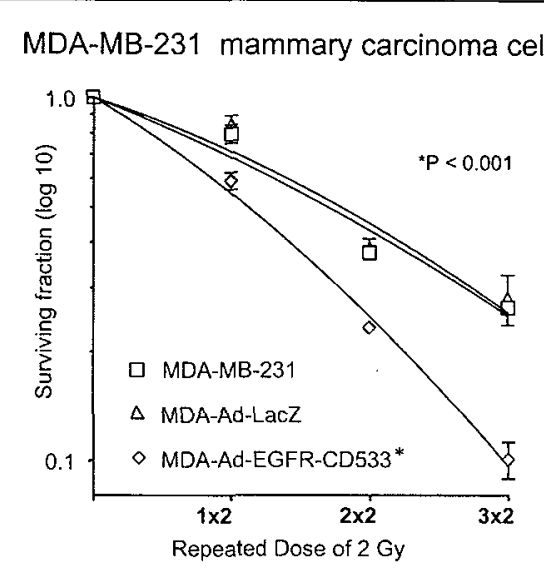

\section{MDA-CD533 mammary carcinoma cells}
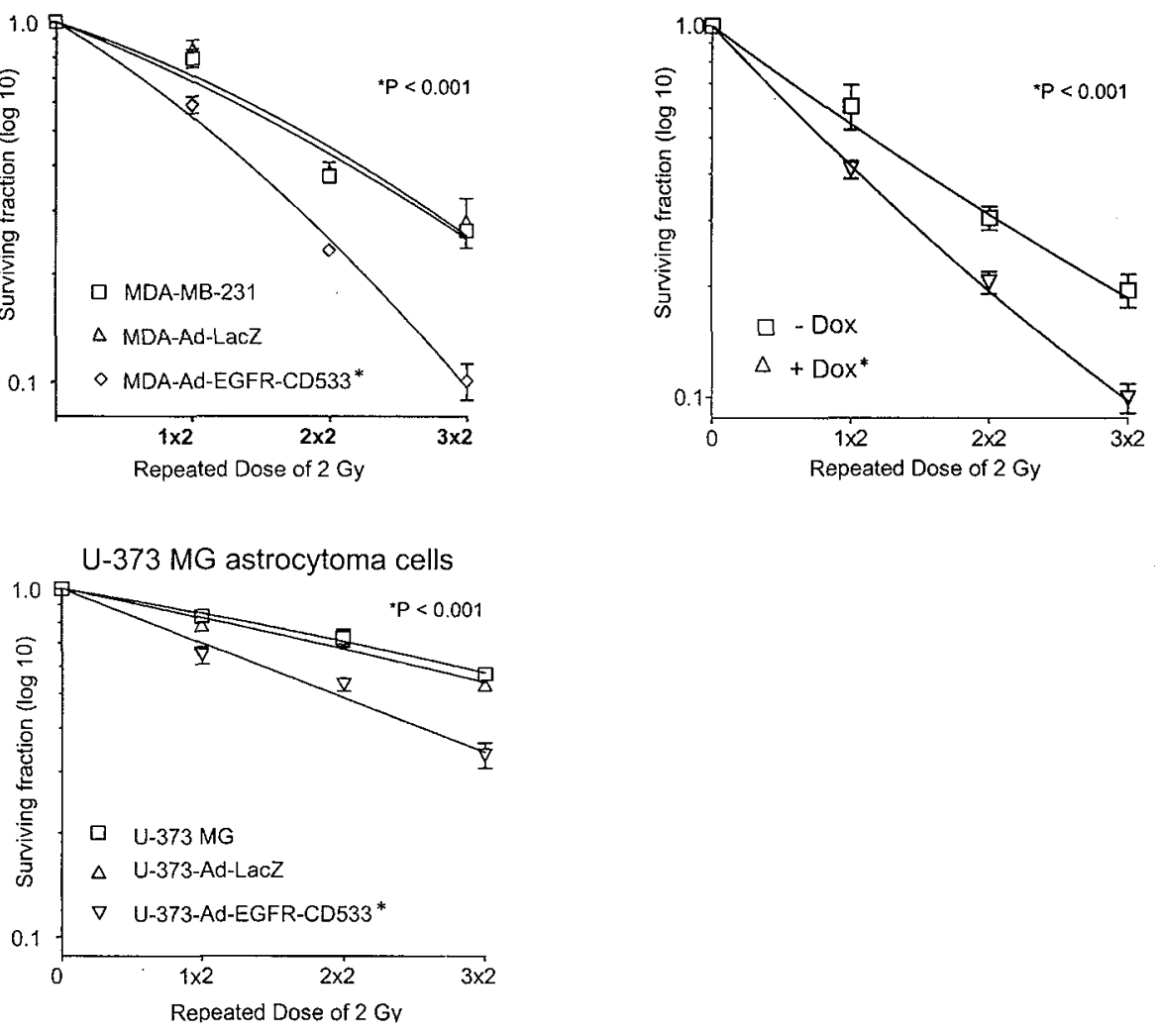

\section{Figure 4}

Figure 1I.2.4: Clonogenic survival after repeated radiation exposures of $3 \times 2 \mathrm{~Gy}$. Cells were treated as described under Fig. 3; for reference purposes, EGFR-CD533 was induced by doxycycline (Dox) in stably transfected MDA-EGFR-CD533 cells. After treatment of cells with Dox or infection with Ad-EGFRCD533, cells were irradiated with three doses of $2 \mathrm{~Gy}$ on three consecutive days. After $24 \mathrm{~h}$ delay cells were plated for clonogenic survival (Fig. 3 legend and "Methods and Materials"). The error bars represent the mean \pm SEM from three experiments.

induced activation of EGFR in MDA-MB-231, U-373 MG (43), and A-431 cells. Radiation at a dose of 2 Gy stimulated EGFR Tyr-P, as reflected in a 2.4- to 3.1-fold increase in EGFR Tyr-P levels within $1 \mathrm{~min}$ (43) (Fig. 2B, left panels), responses that are in line with those previously reported for human carcinoma cells (22). In contrast, this radiation-induced activation of EGFR was completely inhibited in all three cell lines upon overexpression of CD533 (43) (Fig. 2B, right 
panels). These results confirm that expression of EGFR-CD533 completely abolishes the radiationinduced activation of EGFR in human carcinoma and glioma cells.

\section{II.2.3.4. Adenovirus-mediated overexpression of EGFR-CD533 radiosensitizes human carcinoma and glioma cells}

Having demonstrated that overexpression of EGFRCD533 disrupts radiation-induced EGFR activation, we examined whether EGFR-CD533 conferred radiosensitization as measured by colony formation assays. Using single radiation dose-response experiments, Ad-LacZ, Ad-EGFRCD533, and mock infected MDA-MB-231, U-373 MG, and A-431 cells were exposed to radiation doses between 1 and 8 Gy followed by plating for clonogenic survival $24 \mathrm{~h}$ later. T-47D cells were included in the analysis because of their prevalence of ErbB4 expression over EGFR. Because of the relatively high baseline cytotoxicity by adenoviral vectors, T-47D cells were exposed only to a single dose of 4 Gy. For all cell lines tested, the survival curves for control vector and mock infected cells were similar (Fig. 3). In contrast, all Ad-EGFR-CD533-infected cell lines demonstrated a significantly enhanced radiosensitivity over the range of radiation doses tested $(p<$ 0.001). The D37 DERs ranged from 1.4 for MDA-MB-231 cells to 1.7 for A-431 cells (Table 1), and there was also a significant $(p<0.01)$ increase of radiosensitivity for T-47D cells after 4 Gy with a DER4 Gy of 1.6. This radiosensitization by EGFR-CD533 was maintained for repeated radiation exposures of $3 \times 2$ Gy. This was reflected in D37 DERs of 1.6 and 1.7 for Ad-EGFRCD533 transduced MDA-MB-231 and U-373 cells, respectively (Table 1; Fig. 4). The alpha enhancement ratios under those conditions were 1.9 for MDA-MB-231 and 2.0 U-373 MG cells (Table 1). Corresponding radiosensitization parameters for stably transfected MDA-EGFRCD533 cells after Dox induction of EGFR-CD533 were D37 and alpha DERs of 1.4 and 1.8, respectively (Table 1; Fig. 4). The data presented demonstrate that overexpression of EGFR-CD533 significantly enhances radiosensitization in all the cell lines tested irrespective of their substantially different ErbB receptor expression profiles. 


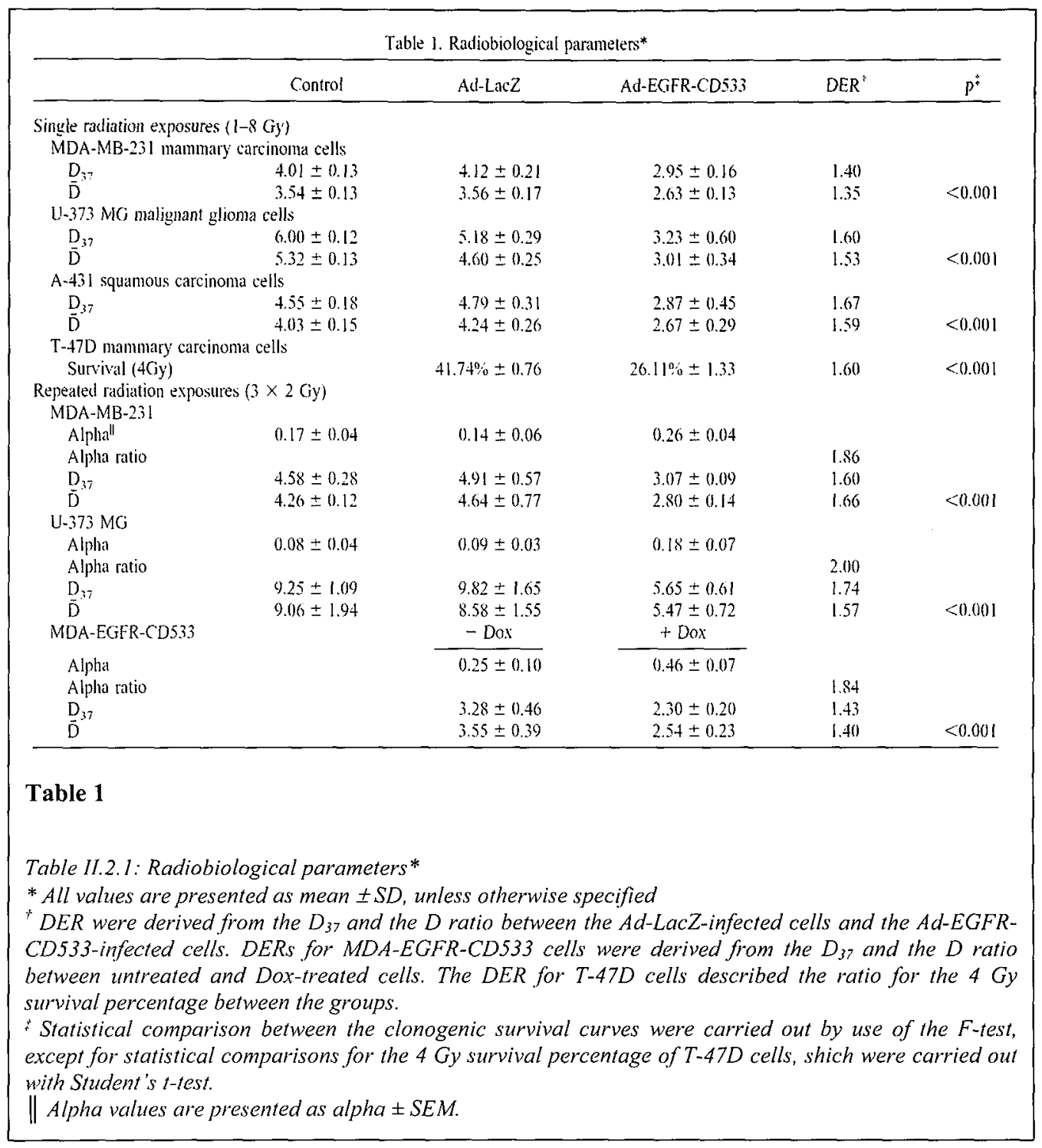

\section{II.2.4. Discussion}

In the present report, we demonstrate that adenovirus mediated expression of EGFR-CD533 in four representative human tumor cell lines, expressing distinctly different profiles of the ErbB receptors, significantly enhances radiosensitivity after single radiation exposures over a 1-8 Gy dose range. Significant DERs between 1.4 and 2.0 derived from several radiobiological parameters were found for all cell lines investigated. Again, similar enhancement ratios were observed after single and repeated radiation exposure experiments. These changes in radiosensitivity were linked to the 
overexpression of DN EGFR CD533 that was effectively induced in all the cells studied and has been shown to inhibit radiation-induced activation of EGFR and the other ErbB receptors. Whereas we have previously shown that EGFR-CD533 expression disrupts the radiation-induced cytoprotective response of accelerated proliferation (27), we now demonstrate the direct radiosensitization by delayed plating clonogenic survival analyses for a spectrum of human tumor cell lines.

The radiosensitizing effect of EGFR-CD533 seen in this report requires that cells are irradiated as undisturbed monolayers and are plated for clonogenic survival $24 \mathrm{~h}$ later. These conditions of delayed plating were not employed in one previous study in which direct radiosensitization of stably transfected MDA-EGFR-CD533 cells could not be documented after single radiation exposures but was limited to a new repeated radiation exposure cell proliferation assay $(27,34)$. There are several possible explanations for the enhanced radiosensitivity of cells expressing EGFR-CD533 in this study. In previous studies cells were irradiated in suspension within $60 \mathrm{~min}$ after trypsinization, a procedure that likely depleted cells of functional surface receptors. Therefore, results from this report provide indirect evidence for the importance of receptor integrity and function in the cytoprotective response of tumor cells after irradiation. Furthermore, the delayed trypsinization $24 \mathrm{~h}$ after irradiation allows one to differentiate between the potential lethal damage repair (PLDR) in control cells expressing endogenous ErbB receptors only and cells overexpressing EGFRCD533. The radiosensitizing effect of EGFR-CD533 observed after repeated 2 Gy exposures and reflected in an enhanced alpha coefficient additionally supports a possible association between PLDR and radiation-induced activation of the ErbB receptors. This conclusion is compatible with a recent more direct demonstration by our and another laboratory that radiation-induced activation of EGFR and its downstream target MAPK may be linked to enhanced DNA damage repair $(44,45)$ through a general stimulation of biosynthetic processes $(46,47)$. Disruption of these responses through disabling EGFR could therefore result in diminished DNA repair and enhanced radiosensitivity as has been suggested for breast and prostate carcinoma cells after blockade of the HER-2 receptor or the MAPK cascade $(48,49)$. The radiosensitization of different tumor cell lines in vitro by adenovirus-mediated overexpression of EGFRCD533 has been extended to in vivo studies for one human malignant glioma cell line (43). In these experiments, the intratumoral infusion of AdEGFR-CD533 resulted in tumor radiosensitization using ex vivo clonogenic survival (43) and tumor growth delay assays (Lammering et al., unpublished).

The varied expression levels of the ErbB molecules in the cell lines examined did not affect the radiosensitization by Ad-mediated overexpression of EGFR-CD533. Importantly, overexpression of 
EGFR-CD533 enhanced radiosensitivity in T-47D cells, expressing very low levels of EGFR, to a similar extent as it did in the other cell lines (Fig. 1). This confirms previous results suggesting that EGFR-CD533 can interact with ErbB-2, ErbB-3, and ErbB-4, all expressed at relatively high levels in T-47D cells, and inhibit their function through heterodimerization at the protein level $(31,32$, 50). Because ionizing radiation indiscriminately activates all ErbB molecules expressed by a given cell line $(24,25,41)$, this approach of trans-receptor inhibition by EGFRCD533 has the advantage of radiosensitizing carcinoma and glioma cells irrespective of the cells' ErbB receptor expression profile, a mechanism that is likely to affect even mutated EGFR receptors with truncated $\mathrm{NH}$ terminal domains (9-11,51; Lammering et al., unpublished).

At present, other approaches that target ErbB molecules for tumor radiosensitization are being pursued (52). CI- 1033, a pharmacologic tyrphostin inhibitor of the EGFR/ ErbB receptor tyrosine kinase domain, inhibited the growth of ErbB-expressing breast carcinoma cells and synergistically enhanced radiosensitivity (52). These results are in agreement with our findings of radiosensitization after blockade of EGFR/ErbB RTK activities. Another area of active research concentrates on $\mathrm{mAbs}$ against EGFR that sterically hinder the binding of growth factor ligands. The best characterized humanized $\mathrm{mAb} \mathrm{C} 225$ has been shown to have radio- and chemosensitizing effects with activity both in vitro and in vivo; C225 is currently tested in clinical trials with promising results $(28,30,53)$. However, C225 targets only EGFR of the four ErbB family members (54), which may limit the ultimate clinical application of this approach. Furthermore, C225 binds to the extracellular ligand-binding domain of EGFR, which suggests that C225 will have limited activity against truncated, constitutively active forms of the EGFR, such as EGFRvIII, also found in a large spectrum of different tumors $(9-11,55-57)$.

In summary, the data presented provide evidence that human mammary carcinoma, squamous carcinoma, and malignant glioma cells can be readily transduced to express DN EGFR-CD533 by a gene therapeutic approach using Ad-EGFR-CD533 and are effectively sensitized to single and repeated exposures of ionizing radiation. We demonstrate that the approach of disarming EGFR function results in remarkably similar radiosensitization and can be applied to a spectrum of neoplastic cells that differ in histopathologic subtype and vary substantially in the EGFR/ErbB receptor expression profiles. The enhanced radiosensitivity was similar for single and repeated radiation exposures, thus identifying the genetic disruption of radiation-induced EGFR activation through overexpression of EGFR-CD533 as a potential therapeutic approach of tumor cell radiosensitization. 


\section{II.2.5. References}

1. Walker RA, Dearing SJ. Expression of epidermal growth factor receptor mRNA and protein in primary breast carcinomas. Breast Cancer Res Treat 1999:53:167-176.

2. Klijn JG, Berns PM, Schmitz PI, et al. The clinical significance of epidermal growth factor receptor (EGF-R) in human breast cancer: A review on 5332 patients. Endocr Rev 1992; 13:3-17.

3. Rusch V, Klimstra D, Venkatraman E, et al. Overexpression of the epidermal growth factor receptor and its ligand transforming growth factor $\alpha$ is frequent in resectable non-small cell lung cancer but does not predict tumor progression. Clin Cancer Res 1997;3:515-522.

4. Fujino S, Enokibori T, Tezuka N, et al. A comparison of epidermal growth factor receptor levels and other prognostic parameters in non-small cell lung cancer. Eur J Cancer 1996;32:2070-2074.

5. Salomon DS, Brandt R, Ciardiello F, et al. Epidermal growth factor-related peptides and their receptors in human malignancies. Crit Rev Oncol Hematol 1995;19:1284-1292.

6. Grandis JR, Melhem MF, Barnes EL, et al. Quantitative immunohistochemical analysis of transforming growth factor- $\alpha$ and epidermal growth factor receptor in patients with squamous cell carcinoma of the head and neck. Cancer 1996; 78:1284-1292.

7. Ekstrand AJ, James CD, Cavenee WK, et al. Genes for epidermal growth factor receptor, transforming growth factor $\alpha$, and epidermal growth factor and their expression in human gliomas in vivo. Cancer Res 1999;51:2164-2172.

8. Scher HI, Sarkis A, Reuter V, et al. Changing pattern of expression of the epidermal growth factor receptor and transforming growth factor alpha in the progression of prostatic neoplasms. Clin Cancer Res 1995;5:545-550.

9. Nishikawa R, Ji XD, Harmon RC, et al. A mutant epidermal growth factor receptor common in human glioma confers enhanced tumorigenicity. Proc Natl Acad Sci USA 1994;91: 7727-7731.

10. Frederick L, Wang XY, Eley G, et al. Diversity and frequency of epidermal growth factor receptor mutations in human glioblastomas. Cancer Res 2000;60:1383-1387.

11. Huang HS, Nagane M, Klingbeil CK, et al. The enhanced tumorigenic activity of a mutant epidermal growth factor receptor common in human cancers is mediated by threshold levels of constitutive tyrosine phosphorylation and unattenuated signaling. J Biol Chem 1997;272:2927-2935.

12. Harris AL, Nicholson S, Sainsbury R, et al. Epidermal growth factor receptor and other oncogenes as prognostic markers. J Natl Cancer Inst Monogr 1992;11:181-187.

13. Slamon DJ, Clark GM, Wong SG, et al. Human breast cancer: Correlation of relapse and survival with amplification of the Her-2/neu oncogene. Science 1987;235:177-182.

14. Grandis JR, Melhem MF, Gooding WE, et al. Levels of TGF- $\alpha$ and EGFR-protein in head and neck squamous cell carcinoma, and patient survival. J Natl Cancer Inst 1998;90: 824-832.

15. Pegram MD, Pauletti G, Slamon DJ. Her-2/neu as a predictive marker of response to breast cancer therapy. Breast Cancer Res Treat 1998;52:65-77.

16. Maurizi M, Almadori G, Ferrandina G, et al. Prognostic significance of epidermal growth factor receptor in laryngeal squamous cell carcinoma. Br J Cancer 1996;74:1253-1257.

17. Pillai M, Jayaprakash $\mathrm{PG}$, Nair M. Tumour-proliferative fraction and growth factor expression as markers of tumour response to radiotherapy in cancer of the uterine cervix. J Cancer Res Clin Oncol $1998 ; 124: 456-461$.

18. Akimoto T, Hunter NR, Buchmiller L, et al. Inverse relationship between epidermal growth factor receptor expression and radiocurability of murine carcinomas. Clin Cancer Res 1999; 5:2884-2890

19. Etienne MC, Pivot X, Formento JL, et al. A multifactorial approach including tumoural epidermal growth factor receptor, $\mathrm{p} 53$, thymidylate synthase and dihydropyrimidine dehydrogenase to predict treatment outcome in head and neck cancer patients receiving 5-fluorouracil. Br J Cancer 1999;79: 1864-1869.

20. Fischer-Colbrie J, Witt A, Hinzl H, et al. EGFR and steroid receptors in ovarian carcinoma: Comparison with prognostic parameters and outcome of patients. Anticancer Res 1997;17: 613-620.

21. Goldkorn $T$, Balaban $N$, Shannon $M$, et al. EGF receptor phosphorylation is affected by ionizing radiation. Biochem Biophys Acta 1997:1358:289-299.

22. Schmidt-Ullrich RK, Valerie K, Fogleman PB, et al. Radiation- induced autophosphorylation of epidermal growth factor receptor in human malignant mammary and squamous epithelial cells. Radiat Res 1996;145:79-83. 
23. Kavanagh BD, Lin PS, Chen P. et al. Radiation-induced enhanced proliferation of human squamous cancer cells in vitro: A release from inhibition by epidermal growth factor. Clin Cancer Res $1995 ; 1: 1557-1562$.

24. Schmidt-Ullrich RK, Dent $P$, Grant $S$, et al. Signal transduction and cellular radiation responses. Radiat Res 2000;153: 245-257.

25. Schmidt-Ullrich RK, Contessa JN, Dent P, et al. Molecular mechanisms of radiation-induced accelerated repopulation. Radiat Oncol Investig 1999;7:321-330.

26. Schmidt-Ullrich RK, Mikkelsen RB, Dent P, et al. Radiationinduced proliferation of the human A431 squamous carcinoma cells is dependent on EGFR tyrosine phosphorylation. Oncogene 1997;15:11911197.

27. Contessa $J \mathbf{N}$, Reardon $\mathrm{DB}$, Todd $\mathrm{D}$, et al. The inducible expression of dominant negative epidermal growth factor receptor CD533 results in radiosensitization of human mammary carcinoma cells. Clin Cancer Res 1999;5:405-411.

28. Bonner JA, Maihle NJ, Folven BR, et al. The interaction of epidermal growth factor and radiation in human head and neck squamous cell carcinoma cell lines with vastly different radiosensitivities. Int $\mathrm{J}$ Radiat Oncol Biol Phys 1994;29:243-247.

29. Knebel A, Rahmsdorf HJ, Ullrich A, et al. Dephosphorylation of receptor tyrosine kinases as target of regulation by radiation, oxidants or alkylating agents. EMBO J 1996;15:5314-5325.

30. Huang SM, Bock JM, Harari PM. Epidermal growth factor receptor with C225 modulates proliferation, apoptosis and radiosensitivity in squamous cell carcinomas of the head and neck. Cancer Res 1999;59:1935-1940.

31. Redemann N, Holzmann B, Rueden TV, et al. Anti-oncogenic activity of signaling-defective epidermal growth factor receptor mutants. Mol Cell Biol 1992;12:491-498.

32. Kashles $\mathrm{O}$, Yarden $Y$, Fisher R, et al. A dominant negative mutation suppresses the function of normal epidermal growth factor receptors by heterodimerization. Mol Cell Biol 1991; 11:1454-1463.

33. Lammering G, Hewit TH, Hawkins WT, et al. Epidermal growth factor receptor as a genetic therapy target for carcinoma cell radiosensitization. J Natl Cancer Inst. 2001;93: 921-929.

34. Reardon DR, Contessa JN, Mikkelsen RB, et al. Dominant negative EGFR-CD533, and inhibition of MAPK modify JNK1 activation, and enhance radiation toxicity of human mammary carcinoma cells. Oncogene 1999;18:4756-4766.

35. Valerie K. Viral vectors for gene delivery. In: Wu-Pong S, Rojanasakul Y, editors. Biopharmaceutical drug design and development. Totowa, NJ: Humana Press; 1999. p. 69-142.

36. Valerie $\mathrm{K}$, Brust $\mathrm{D}$, Farnsworth $\mathrm{J}$, et al. Improved radiosensitization of rat glioma cells with Adenovirus-expressed mutant HSV-TK in combination with acyclovir. Cancer Gene Ther 2000;7:879884.

37. Brust D, Feden J, Farnsworth J, et al. Radiosensitization of rat glioma with bromodeoxycytidine and Adenovirus expressing HSV-TK delivered by slow positive pressure infusion. Cancer Gene Ther 2000;7:778--788.

38. Ho KC, Lin PS. Safranin O counterstaining enhances the counting of $\beta$-galactosidase-expressing cells. BioTechniques 1997;23:642.

39. Hall EJ. Cell survival curves. In: Hall EJ, Ryan JD, Cox K, Papadopoulos D, editors. Radiobiology for the radiologist. $4^{\text {th }}$ ed. Philadelphia: Lippincott; 1994. p. 41.

40. Fertil B, Dertinger H, Courdi A, et al. Mean inactivation dose: A useful concept for intercomparison of human cell survival curves. Radiat Res 1984;99:73-84.

41. Bowers $\mathrm{G}$, Reardon $\mathrm{D}$, Hewit $\mathrm{TH}$, et al. The relative role of ErbBI-4 receptor tyrosine kinases in radiation signal transduction responses of human carcinoma cells. Oncogene 2001; 20:1388-1397.

42. Gulliford TJ, Huang GC, Ouyang X, et al. Reduced ability of transforming growth factor-alpha to induce EGF receptor heterodimerization and downregulation suggests a mechanism of oncogenic synergy with ErbB2. Oncogene 1997;15:2219-2223.

43. Lammering G, Valerie K, Lin PS, et al. Radiosensitization of malignant glioma cells through overexpression of dominantnegative epidermal growth factor receptor. Clin Cancer Res 2001;7:682690.

44. Huang SM, Harari PM. Modulation of radiation response after epidermal growth factor receptor blockade in squamous cell carcinomas: Inhibition of damage repair, cell cycle kinetics, and tumor angiogenesis. Clin Cancer Res 2000;6:2166-2174. 
45. Carter S, Auer KL, Birrer M, et al. Inhibition of the mitogen activated protein (MAP) kinase cascade potentiates cell killing by low dose ionizing radiation in A431 human squamous carcinoma cells. Oncogene 1998;16:2787-2796.

46. Sale EM, Atkinson PP, Arnott CH, Chad JE, Sale GJ. Role of ERK1/ERK2 and p70S6K pathway in insulin signaling of protein synthesis. FEBS Lett 1999;446:122-126.

47. Kawasome H, Papst P, Webb S, et al. Targeted disruption of p70 (s6k) defines its role in protein synthesis and rapamycin sensitivity. Proc Natl Acad Sci USA 1998;95:5033 -5038.

48. Pietras RJ, Poen JC, Gallardo D, et al. Monoclonal antibody to HER-2/neu receptor modulates repair of radiation-induced DNA damage and enhances radiosensitivity of human breast cancer cells overexpressing this oncogene. Cancer Res 1999; 59:1347-1355.

49. Hagan M, Wang L, Hanley JR, et al. Ionizing radiationinduced mitogen-activated protein (MAP) kinase activation in DU145 prostate carcinoma cells: MAP kinase inhibition enhances radiationinduced cell killing and G2/M-phase arrest. Radiat Res 2000;153:371-383.

50. Earp HS, Dawson TL, Li X, et al. Heterodimerization and functional interaction between EGF receptor family members: A new signaling paradigm with implications for breast cancer research. Breast Cancer Res Treat 1995;35:115-132.

51. Batra SK, Castelino-Prabhu S, Wikstrand CJ, et al. Epidermal growth factor ligand-independent, unregulated, cell-transforming potential of a naturally occuring human mutant EGFRvIII gene. Cell Growth Differ 1995;6:1251-1259.

52. Rao GS, Murray S, Ethier SP. Radiosensitization of human breast cancer cells by a novel ErbB family receptor tyrosine kinase inhibitor. Int $J$ Radiat Oncol Biol Phys 2000;48:1519- 1527.

53. Milas L, Mason K, Hunter N, Petersen S, Yamakawa M, Ang K, Mendelsohn J, Fan Z. In vivo enhancement of tumor radioresponse by $\mathrm{C} 225$ antiepidermal growth factor receptor antibody. Clin Cancer Res 2000;6:701-708.

54. Gill GN, Kawamoto $\mathrm{T}$, Cochet $\mathrm{C}$, et al. Monoclonal antiepidermal growth factor antibody to the epidermal growth factor receptor: Immunologically mediated and effector cellindependent effects. Cancer Res 1987;47:3692-3696.

55. Olapade-Olaopa EO, Moscatello DK, MacKey EH, et al. Evidence for the differential expression of a variant EGF receptor protein in human prostate cancer. Br J Cancer 2000; 82:186-194.

56. Moscatello DK, Holgado-Madruga M, Godwin AK, et al. Frequent expression of a mutant epidermal growth factor receptor in multiple human tumors. Cancer Res 1995;55: 5536-5539.

57. Wikstrand CJ, MeLendon RE, Friedman AH, et al. Cell surface location and density of the tumorassociated variant of the epidermal growth factor receptor, EGFRvIII. Cancer Res 1997;57:4130-4140. 


\section{Chapter III}

III.1. Radiosensitization of malignant glioma cells through overexpression of dominant-negative EGFR

Published in: Clin Cancer Res. 7: 682-690, $2001(\mathrm{IF}=\mathbf{5 . 0 7})$

Guido Lammering, Kristoffer Valerie, Peck-Sun Lin, Ross B. Mikkelsen, Joseph N. Contessa, Jeffrey P. Feden, Julie Farnsworth,

Paul Dent and Rupert K. Schmidt-Ullrich 


\section{Summary}

The epidermal growth factor receptor (EGFR) plays an important role in neoplastic growth control of malignant gliomas. We have demonstrated that radiation activates EGFR Tyr-phosphorylation (EGFR Tyr-P) and the proliferation of surviving human carcinoma cells, a likely mechanism of accelerated cellular repopulation, a major cytoprotective response following radiation. We now investigate the importance of radiation-induced activation of EGFR on the radiosensitivity of the human malignant glioma cells U-87 MG and U-373 MG. The function of EGFR was inhibited through a genetic approach of transducing cells with an Adenovirus (Ad) vector containing dominant-negative (DN) EGFR-CD533 (Ad-EGFR-CD533) at efficiencies of 85-90\%. The resulting cells are referred to as U-87-EGFR-CD533 and U-373-EGFR-CD533. After irradiation at $2 \mathrm{~Gy}$, both cell lines exhibited a mean 3- fold increase in EGFR Tyr-P. The expression of EGFRCD533 completely inhibited the radiation-induced activation of EGFR. In clonogenic survival assays after a single radiation exposure the $\mathrm{D}_{37}$ dose for U-87-EGFR-CD533 cells was 1.4- to 1.5fold lower relative to cells transduced with AdLacZ or untransduced U-87 MG cells. This effect was amplified with repeated radiation exposures $\left(3 \times 2 \mathrm{~Gy}\right.$ ) yielding a $\mathrm{D}_{37}$ ratio of 1.8 to 2.0 . In clonogenic survival studies with U-373 MG cells, the radiosensitizing effect of EGFR-CD533 was similar. Furthermore, in vivo studies with U-87 MG xenografts confirmed the effect of EGFRCD533 on tumor radiosensitization (dose enhancement ratio 1.8). We conclude that inhibition of EGFR function via Ad mediated gene transfer of EGFR-CD533 results in significant radiosensitization. As underlying mechanism we suggest the disruption of a major cytoprotective response involving EGFR and its downstream effectors, such as mitogen-activated protein kinase (MAPK). The experiments demonstrate for the first time that radiosensitization of malignant glioma cells through disruption of EGFR function may be achieved by genetic therapy approaches. 


\section{III.1.1. Introduction}

Receptor Tyr kinases (RTKs) of the ErbB family and related plasma membrane receptors have been identified as critical components facilitating autocrine growth regulation of carcinoma and malignant glioma cells typically the result of coordinate co-expression of growth factors (GFs) and their receptors (1-4). The activation of RTKs and stimulation of downstream signaling pathways mediating mitogenesis have been indentified as the underlying mechanism (4). Among the ErbB RTKs, EGFR has been extensively studied including its involvement in the neoplastic progression of human carcinoma and malignant glioma cells $(3,5)$. EGFR, a $170 \mathrm{kD}$ transmembrane glycoprotein, contains a GF binding site in the extracellular $\mathrm{NH}_{2}$-portion of the molecule and an intracellular Tyr kinase domain in the cytoplasmic COOH-terminal portion $(2,3)$. The phosphorylation of Tyr, Ser, and Thr residues in the cytoplasmic portion are critical for its activation and downstream signaling $(4,6)$. As has been demonstrated for malignant gliomas and carcinomas, EGFR amplification and/or genetic modification, e.g. truncation, is critically linked to neoplastic progression $(7,8)$.

We have recently demonstrated a role for EGFR in cellular responses to single and repeated ionizing radiation exposures $(6,9,10,11)$. The activation of EGFR by radiation resembles that of GFs with immediate EGFR activation as reflected by increased phosphorylation of defined Tyr residues in the cytoplasmic domain $(9,11,12)$. The consequence of EGFR activation includes the stimulation of downstream kinases, such as MAPK (11). In our detailed characterization of radiation effects along the EGFR-MAPK signaling cascade (4) we have linked the activation of EGFR to a cellular proliferation response $(4,10,11,13,14)$ and concluded that EGFR mediates radiation-induced proliferation in surviving cells. This represents a likely mechanism underlying radiation induced accelerated cellular repopulation $(4,6,10)$. Since accelerated tumor cell proliferation counteracts the cytotoxic effects of radiation it has to be viewed as a major cytoprotective response $(4,6)$. Thus, disruption of this response may be one mechanism of radiosensitizing tumor cells.

Considering the poor response of human malignant gliomas, especially glioblastomas, to radiotherapy we have investigated the importance of radiation-induced activation of EGFR on the radiosensitivity of human malignant glioma cells. For this we have used a genetic approach by transducing cells with DN EGFR-CD533, which lacks 533 amino acids of the cytoplasmic domain responsible for mitogenic and transforming activities of the receptor (15). We have previously shown that over-expression of EGFR-CD533 completely abrogates radiation-induced activation of EGFR in human carcinoma cells with secondary complete suppression of the MAPK and radiation- 
induced proliferation responses $(4,6,11,13)$. Therefore, we now investigate whether inhibiting EGFR function through over-expression of EGFR-CD533 results in radiosensitization of malignant glioma cells. In line with our interest in genetic therapy approaches the effects of over-expression of EGFR-CD533 were studied after in vitro Ad transduction of two human malignant glioma cell lines and also after Ad infusion in U-87 MG tumor xenografts. 


\section{III.1.2. Materials and Methods}

\section{III.1.2.1. Cell Lines and Reagents}

Two human glioma cell lines were used in the present study; U-373 MG, originally isolated from a human anaplastic astrocytoma, and U-87 MG, a human glioblastoma cell line, were obtained through the American Type Tissue Collection (ATCC; Rockville, MD). U-87 MG cells express wild-type p53 (p53wt), whereas U-373 MG cells express a mutated p53 (p53mut) gene product $(16,17)$. Human epidermoid carcinoma A 431 cells were also obtained from ATCC. The cell lines were tested for mycoplasma contamination monthly and only negative cells were used for experimentation.

Protease and phosphatase inhibitors and other chemical reagents were purchased from Sigma Chemical Co. (St.Louis, MO). All electrophoresis reagents were from BioRad (Hercules, CA). The Minimum Essential Medium $\alpha$ Medium (MEM Alpha) and the Penicillin-Streptomycin antibiotics were from GIBCO-BRL (Rockville, MD), and fetal bovine serum (FBS) was from Intergen (Purchase, NY).

The following immunological reagents from Neo Markers (Fremont, CA) were used: the monoclonal antibody (mAb) cocktail (Ab14) reacting with both $\mathrm{COOH}$ - and NH2-terminal domains of EGFR, the anti-ErbB2 mAb cocktail (Ab10), reacting with both the extracellular and cytoplasmic domains of ErbB2, and the anti-ErbB3 mAb (Ab7) and anti-ErbB4 mAb (Ab4), that react with the cytoplasmic domains of ErbB3 and ErbB4, respectively. Other antibodies were: anti-EGFR $\mathrm{mAb}$ from Transduction Laboratories (PharMingen/ Transduction Laboratories, Los Angeles, CA), the anti-EGFRvIII mAb reacting with the N-terminal truncation of EGFR, DH8.3 (AbCam Limited, Cambridge, UK), the immunoprecipitating anti-EGFR mAb, Ab5, the anti-phospho-Tyr mAb, Ab2, and peroxidase-conjugated goat anti-mouse $\mathrm{Ab}$ (Oncogene Science, Cambridge, MA). Protein $\mathrm{A}$ agarose was from BioRad (Hercules, CA).

\section{III.1.2.2. Mice and Tumors}

Athymic female NCr-nu/nu nude mice were obtained from the National Cancer Institute-Frederick Cancer Research Facility (Frederick, MD). Animals used in this study were maintained under specific-pathogen-free conditions in facilities approved by the American Association for Accreditation of Laboratory Animal Care and in accordance with current regulations and standards of the U. S. Department of Agriculture, U.S. Department of Health and Human Services, and the National Institutes of Health. Solitary tumors were produced by subcutaneous inoculation of $10^{7}$ 
cells into the right hind leg of 2 to 3 month old mice. Tumor cell suspensions were prepared from U-87 MG cells grown as monolayers in vitro. Experiments were initiated when the tumors had reached a size of $8-10 \mathrm{~mm}$ in diameter.

\section{III.1.2.3. Recombinant Adenoviruses and in vitro Transduction Conditions}

Replication-incompetent Ad was produced in bacteria as previously described $(18,19)$. The mutant EGFR-CD533 cDNA (20), lacking the 533 carboxyl-terminal amino acids, was kindly provided by A. Ullrich (Max-Planck-Institut fuer Biochemie Martinsried, Germany). An Ad expressing the bacterial lacZ reporter gene (AdLacZ) was used as control virus $(19,21)$. The transduction rate in AdLacZ transduced cells expressing $B$-galactosidase ( $\beta$-gal) was determined by $x$-gal staining after 5-bromo-4-chloro-3-indolyl-B-D-galactopyranoside incubation for $24 \mathrm{~h}$ as previously described (21). In order to identify lacZ gene-negative cells more accurately, safranin $O$ was used for counterstaining (22). Ad-EGFR-CD533 or AdLacZ was produced in 293 cells as described and purified by double $\mathrm{CsCl}$ gradient centrifugation followed by dialysis against $13 \%$ glycerol in phosphate-buffered saline $(19,21)$. Virus was frozen in liquid nitrogen and stored at $-70^{\circ} \mathrm{C}$ until further use. Titration by standard plaque assay indicated typical titers of $2 \times 10^{11}$ plaque-forming units per $\mathrm{ml}(\mathrm{pfu} / \mathrm{ml})$.

Transduction of the cell lines with Ad-EGFR-CD533 or AdLacZ was carried out by diluting viral stocks with PBS, adding adenoviral preparations to cell monolayers (60-mm dish) and placing dishes on a rocker with gentle continuous agitation in a tissue culture incubator for $4 \mathrm{~h}$ at $37^{\circ} \mathrm{C}$ followed by medium change. The multiplicity of infection (MOI) (pfu/cell) was optimized for maximum transduction and minimum cell toxicity.

\section{III.1.2.4. Cell Treatments and in vitro Irradiation}

U-87 MG and U-373 MG cells were seeded at $1.9 \times 10^{5}$ (60-mm-dish) / $8.0 \times 10^{5}$ (100-mm dish) or $1.5 \times 10^{5}$ (60mm-dish) $/ 4 \times 10^{5}$ (100-mm dish), respectively, and cultured for a total of 4 to 5 days in MEM Alpha containing 10\% FBS (MEM Alpha/10FBS) and penicillin/streptomycin. For clonogenic survival analyses, cells were transduced on day 3 with Ad-EGFR-CD533, AdLacZ or left untransduced in $1 \mathrm{ml}$ of medium (60-mm dish). For immunochemical analyses after irradiation or EGF treatments, media was replaced by low serum MEM Alpha/0.5FBS for $16 \mathrm{~h}$ prior to irradiation or EGF treatment. In all radiation experiments, cells were irradiated at a dose rate of 1.8 Gy $/$ min using a ${ }^{60} \mathrm{Co}$ source. Cells were maintained at $37^{\circ} \mathrm{C}$ throughout the experiment except for irradiation at $20^{\circ} \mathrm{C}$. For time course experiments, cells were irradiated with a single dose of 2 Gy 
and incubated for the times specified. Thereafter, medium was removed and cells were washed once in ice-cold PBS, immediately frozen on dry ice, and stored at $-70^{\circ} \mathrm{C}$ until further processing.

\section{III.1.2.5. EGFR Tyr-P and Western blot analysis}

Immunoprecipitations and Western blotting were performed as described (9); briefly, frozen cells were lysed in ice-cold lysis buffer. Cell lysis was facilitated by repeated passage through a 20-gauge needle and insoluble material was removed by centrifugation at $14,000 \times \mathrm{g}$ for $10 \mathrm{~min}$. For time course experiments, equivalent amounts of protein, quantified by the Bradford Protein Standard Assay (BioRad, Hercules, CA) were reacted with $\mathrm{Ab5}$ at $4^{\circ} \mathrm{C}$ for $90 \mathrm{~min}$ followed by incubation with protein A-agarose for $45 \mathrm{~min}$. Agarose was recovered by centrifugation and immunoprecipitates were washed once in lysis buffer and twice in PBS. Proteins were size fractionated in $6 \%$ SDS-polyacrylamide gels, transferred electrophorectically onto nitrocellulose membranes (BioRad, Hercules, CA), and probed with anti-phospho-Tyr mAb Ab2 (EGFR Tyr-P studies) or anti-EGFR mAb (EGFR-protein studies) followed by incubation with peroxidaseconjugated secondary Ab. After developing with CDP-Star (Tropix, Inc., Bedford, MA), autoradiograms were quantified using Sigma Scan software (Jandel Scientific, San Rafael, CA) (9). Ab14 was used for Western blotting of EGFR, Ab10 for ErbB2, Ab7 and Ab4 for ErbB3 and ErbB4, respectively.

\section{III.1.2.6. Colony Formation Assay}

Cells were incubated on day 3 with Ad-EGFR-CD533, AdLacZ or left untransduced in Iml of medium (60-mm-dish) for $4 \mathrm{~h}$ followed by medium change. After $48 \mathrm{~h}$, cells were irradiated with single doses of 2, 4, and 8 Gy and, after incubation for an additional $24 \mathrm{~h}$, harvested and plated for clonogenic survival. For repeated radiation exposure experiments, cells were exposed once daily to 2 Gy for 3 consecutive days without medium change. The number of cells was adjusted to generate 50 - 300 colonies per dish at each radiation dose and plated into 4-well $6 \mathrm{~cm}$ culture dishes. Cells were incubated at $37^{\circ} \mathrm{C}$ with $5 \% \mathrm{CO}_{2}$ for 12 - 14 days, stained with crystal violet, and colonies containing $\geq 50$ cells were counted to determine surviving fraction (23).

\section{III.1.2.7. Adenoviral Infusion in U-87 MG Tumors and In Vivo Irradiation}

At tumor diameters of 8 to $10 \mathrm{~mm}$, AdLacZ (control) or Ad-EGFR-CD533 was delivered intratumorally as follows. Six 30-gauge needles were positioned as two sets of 3 needles in a triangular arrangement in opposing directions and penetrated to approximately $60 \%$ of the diameter of the tumor with appropriate spacing between the needles to allow for maximal Ad distribution. In addition, each needle was retracted $1 \mathrm{~mm}$ every $10 \mathrm{~min}$ during the infusion. A Bee Hive Controller 
and a Baby Bee Syringe Pump (Bioanalytical Systems, Inc. West Lafayette, Indiana) were used for all Ad infusions. All infusions were performed on fully anaesthetized mice with a total volume of $20 \mu \mathrm{l}$ per needle containing $1 \times 10^{9} \mathrm{pfu}$ AdLacZ or Ad-EGFR-CD533 using a PBS vehicle. The flow rate was $0.5 \mu \mathrm{l} / \mathrm{min}$. At $72 \mathrm{~h}$ post-infusion, mice were immobilized in a plastic box, and animals were centered in a $18 \times 18-\mathrm{cm}$ field. A single 3 Gy dose of gamma radiation was delivered whole body on 3 consecutive days at a dose rate of $2 \mathrm{~Gy} / \mathrm{min}$ using a ${ }^{60} \mathrm{Co}$ source. Control tumors infused with AdLacZ or Ad-EGFR-CD533 were handled under mock radiation conditions.

\section{III.1.2.8. Measures of tumor radiosensitization}

An ex vivo colony formation assay was performed to assess radiosensitization in vivo. Twenty-four $\mathrm{h}$ after irradiation, mice were sacrificed and tumors were excised and digested to single cell

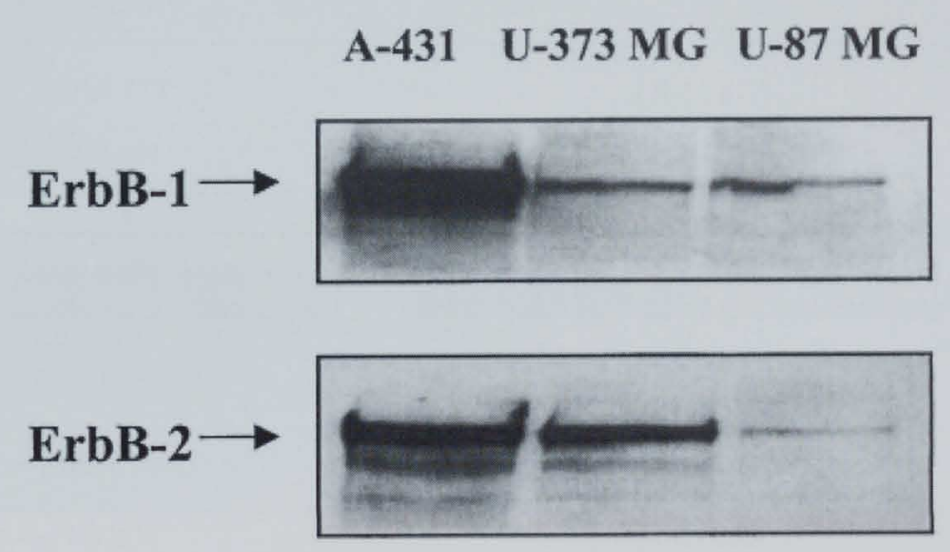

Figure 1

Figure III.1.1. Western blot analysis of the expression levels of EGFR and ErbB-2 in U-87 MG and U-373 $M G$ cells compared to the squamous carcinoma cell line A-431. Cell lysates for each cell line were size fractionated by SDS-PAGE and immunoblotted with $m A B$ specific for EGFR and ErbB-2. Protein standard assays were performed to control for equal loading of protein.

suspension in $1.5 \mathrm{ml}$ of collagenase $(280 \mathrm{U} / \mathrm{ml}$ ) and $1.5 \mathrm{ml}$ of an enzyme cocktail (DNase $(30.58 \mathrm{U} / \mathrm{ml})$, pronase $(225 \mathrm{U} / \mathrm{ml})$, collagenase $(3280 \mathrm{U} / \mathrm{ml}))$, contained in $15 \mathrm{ml}$ of $\mathrm{MEM}$ Alpha/10FBS plus antibiotics. After 2 to $3 \mathrm{~h}$ of digestion, single cells were filtered through a 40 micron mesh filter, washed twice with media and counted. The cells were then plated for colony formation assay as described above. 
The Student's t test was applied to establish statistical significance.

\section{III.1.3. Results}

\section{III.1.3.1. Characterization of EGFR- and ErbB2 protein expression}

In order to define the expression levels of EGFR and ErbB2 in the two glioma cell lines, we confirmed surface receptor expression for each of the two cell lines relative to the A-431 cells using $\mathrm{mAbs}$ for EGFR and ErbB2. Immunoblotting experiments with Ab14 against EGFR revealed a single $170 \mathrm{kD}$ band in A-431, U-373 MG, and U-87 MG cell lysates (Figure 1) However, the EGFR expression levels in the two glioma cell lines were substantially lower than in A-431 cells. No additional 145-155 kD band, representing the receptor with a truncated COOH-terminal domain (EGFRvIII) was evident. Western blotting with Ab10 showed similar ErbB2 protein levels of the
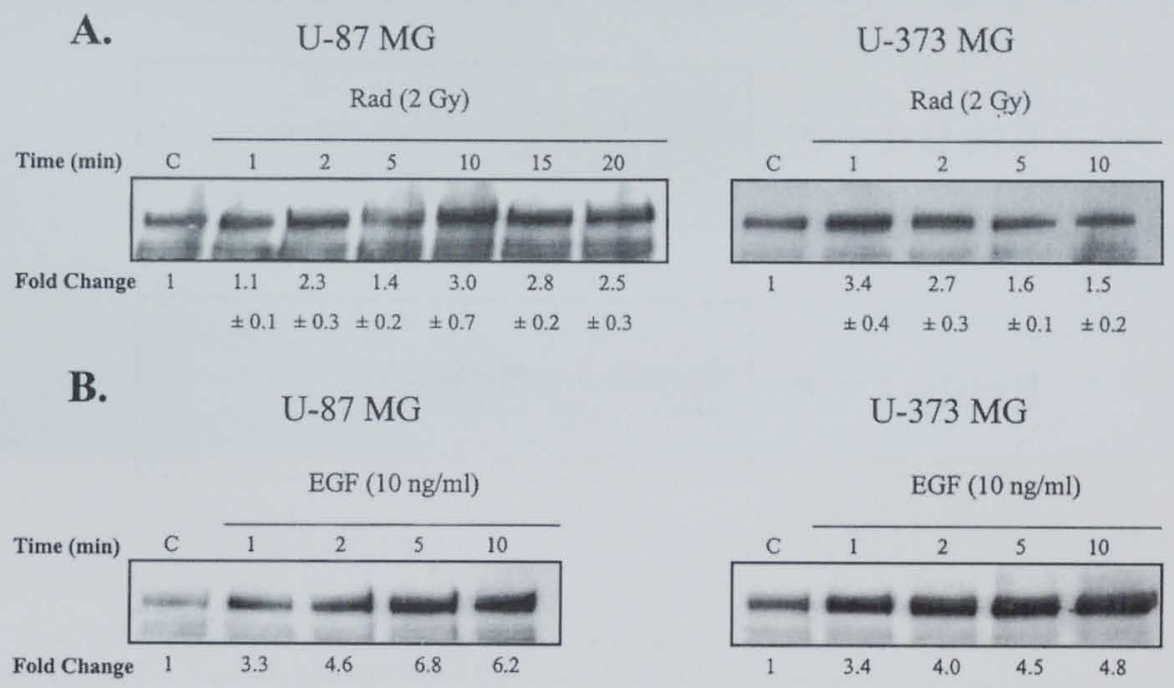

\section{Figure 2}

Figure III.1.2. Radiation- (A.) and EGF-(B.) induced EGFR Tyr-P at specified times after radiation exposure of $2 \mathrm{~Gy}$ or $10 \mathrm{ng} / \mathrm{ml}$ of EGF in U-87 MG and U-373 MG cells. Cell lysates were immunoprecipitated with anti-EGFR $M A b$ and size fractionated by SDS-PAGE; Western blots were reacted with anti-phospho-Tyr $m A b$, and the reaction was quantified by chemiluminescence and densitometric scanning. The corresponding values of relative phospho-Tyr levels represent increases over the negative control $(\boldsymbol{C})$. Values in $A$. are representative of three independent experiments and are given as mean $\pm S D$. 
$185 \mathrm{kD}$ protein in A-431 and U-373 MG cells, whereas the ErbB2 expression level in U-87 MG cells was lower (Figure 1). No ErbB3 or ErbB4 and no EGFRvIII bands were found in U-87 MG and U-373 MG cell lysates after immunoblotting with Ab7, Ab4, and anti-EGFRvIII respectively (data not shown). The results demonstrate that both glioma cell lines express significant levels of EGFR and ErbB2.

\section{III.1.3.2. Radiation-induced activation of EGFR Tyr-P in U-87 MG and U-373 MG cell lines}

We have previously demonstrated that radiation in the dose range of $0.5-5 \mathrm{~Gy}$, similar to EGF stimulates EGFR Tyr-P in MCF 7, MDA-MB-231, and A-431 cells (10). In order to test these responses in the malignant glioma cells, U-87 MG and U-373 MG, EGFR activation after radiation and EGF exposure was quantified by relative levels of EGFR Tyr-P using Western analysis (Figure 2). A 2 Gy radiation exposure resulted in maximum stimulation of EGFR activation in U-373 MG cells within $1 \mathrm{~min}$, whereas U-87 MG cells showed a prolonged response with a maximum EGFR activation at $10 \mathrm{~min}$ (Figure $2 \mathrm{~A}$ ). In three independent experiments, means of $3.0( \pm 0.7)$ - (U-87 MG; $95 \%$ confidence interval: $1.86,3.18 ; \mathrm{P}<0.005)$ to $3.4( \pm 0.4)-(\mathrm{U}-373 \mathrm{MG} ; 95 \%$ confidence interval: $1.84,3.28 ; \mathrm{P}<0.001$ ) fold increase relative to the controls were observed; responses in line with those previously found for human carcinoma cells $(10,14)$. EGF exposure led to a prolonged increase of EGFR Tyr-P in both cell lines (Figure 2B).

III.1.3.3. Transduction of U-87 MG and U-373 MG malignant glioma cells in vitro 
The over-expression of EGFR-CD533 was studied through a genetic approach of transducing cells with Ad-EGFR-CD533. To optimize the MOI for maximum transduction with minimum cell toxicity in U-87 MG and U-373 MG cells, we evaluated different MOI's between 3 and 30 for the
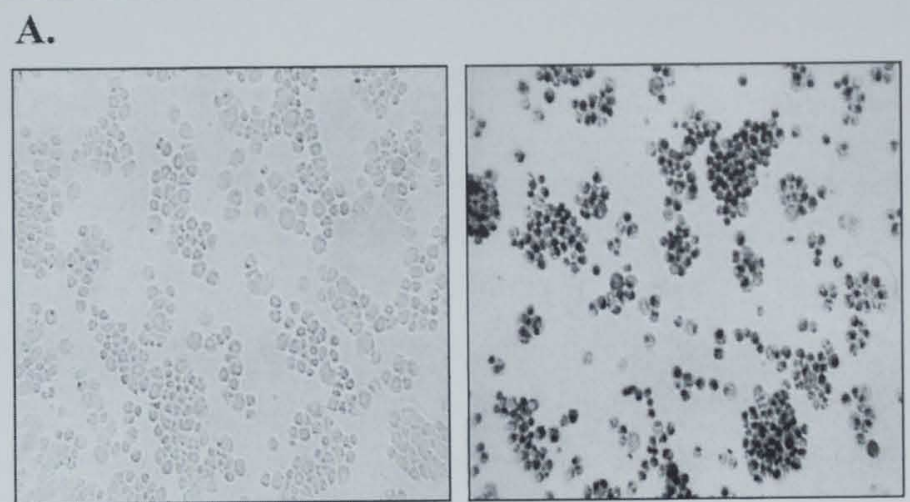

B.

AdLacZ infection

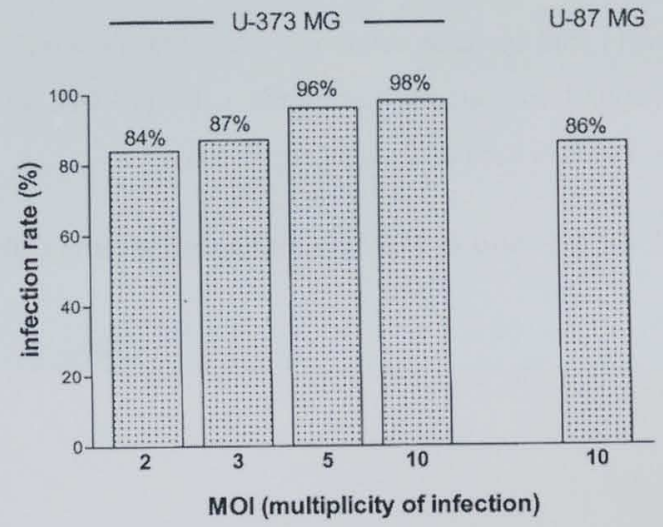

Figure 3

Figure III.1.3. A, nuclear $x$-gal staining for $\beta$-gal expression 48 hours after transduction with AdLacZ (10 MOI) in U-87 MG cells at the time when radiation was performed in radiation experiments (see "Material and Methods"). The nuclear staining of $x$-gal detects transduced cells with a blue color. Safranin $O$, used as counterstaining, stains cytoplasm and nuclei light red. The overall transduction rate was estimated as $86-89 \%$. The left panel shows x-gal staining and safranin $O$ counterstaining for untransduced cells. B, U-373 MG cells were transduced at increasing MOI with LacZ expression recombinant Adenovirus (AdLacZ) to determine the efficiency of transduction. The percent transduction was determined by counting 500 cells at each level of transduction and verifying the number of stained cells versus unstained cells. For further experimental settings, 3 MOI was chosen for U-373 MG cells and $10 \mathrm{MOI}$ for U-87 MG cells respectively with an overall transduction rate $>85 \%$. 
transduction of cells with AdLacZ and Ad-EGFR-CD533. We examined the transduction rate of AdLacZ after $x$-gal staining (Figure 3A), the expression levels of EGFR-CD533 by Western analysis and the toxicity by colony formation assay. We established that $10 \mathrm{MOI}$ for U-87 MG and 3 MOI for U-373 MG cells produced $85-90 \%$ transduction efficiencies (Figure 3B). Under these conditions, the survival rates by colony formation were $96 \%$ and $80 \%$ for U-87 MG and U-373 MG cells, respectively, relative to untransduced controls (data not shown). Overall, U-373 MG cells demonstrated a greater sensitivity to adenoviral transduction than U-87 MG cells (Figure $3 \mathrm{~B}$ ). The expression level of the newly expressed EGFR-CD533 was detectable $24 \mathrm{~h}$ after the transduction, and approached maximum values by $48 \mathrm{~h}$, as previously described (13; data not shown).

III.1.3.4. Inhibition of radiation-induced activation of EGFR Tyr-P by over-expression of EGFR-CD533 via Ad-mediated gene transfer 


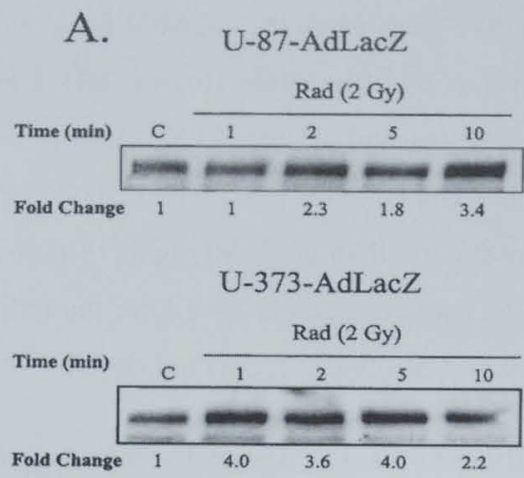

B.

(10 MOI)

U-87-AdLacZ U-87-EGFRCD533 U-373-AdLacZ U-373-EGFR-CD533
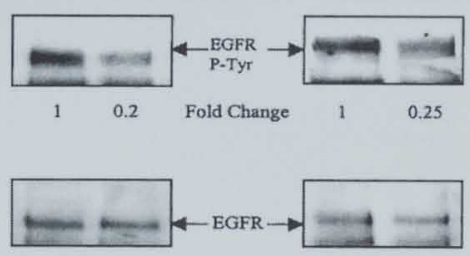

\section{U-87-EGFR-CD533}

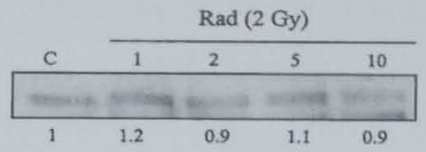

\section{U-373-EGFR-CD533}

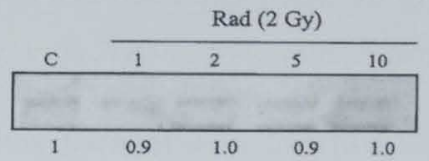

C.

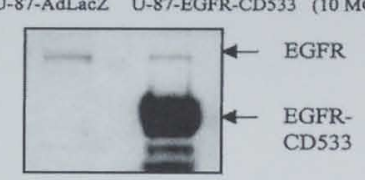

U-373-AdLacZ U-373-EGFR-CD533 (3 MOI)

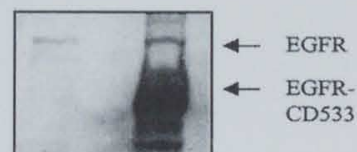

\section{Figure 4}

Figure III.1.4. A, radiation-induced EGFR Tyr-P is blocked by EGFR-CD533 expression. U-87 MG and U-373 MG cells were transduced with either control AdLacZ or Ad-EGFR-CD533 with an MOI of 10 or 3 respectively and 48 hours later exposed to $2 G y$ radiation. Cell lysates were immunoprecipitated with antiEGFR $m A b$ and size fractionated by SDS-PAGE; Western blots were reacted with anti-phospho-Tyr $m A b$, and the reaction was quantified by chemi-luminescence and densitometric scanning. $\boldsymbol{B}$, the decrease in relative basal EGFR Tyr-P levels in Ad-EGFR-CD533 transduced cells over the control AdLacZ transduced cells for both cell lines (top lanes). Bottom lanes, in parallel, cell lysates from the samples shown in the top lanes immunoprecipitated with anti-EGFR $M A b$, size fractionated by SDS-PAGE and immunoblotted with a $C$-terminal binding anti-EGFR $m A b$ to ensure for equal EGFR protein loading. $C$, western blot analysis of the expression levels of EGFR and EGFR-CD533 at the time, when radiation was performed in panel A. Cell lysates were size fractionated by SDS-PAGE and immunoblotted with a mAb cocktail reacting with both $\mathrm{COOH}$ - and NH2-terminal domains of EGFR.

Previous studies had established that expression of EGFR-CD533 does not affect the expression levels of EGFR, but disrupts wild-type EGFR function and autophosphorylation through protein interaction (13). Radiation-induced activation of EGFR in U-87 MG and U-373 MG cells was inhibited through over-expression of EGFR-CD533 using the Ad-EGFR-CD533 and an AdLacZ 
control virus to assess to the effects of vector alone on EGFR Tyr-P. The results shown in Figure 4 demonstrate that AdLacZ did not affect the radiation-induced activation of EGFR in U-87 MG and U-373 MG cells. This EGFR activation was completely inhibited in U-87 MG and U-373 MG cells under conditions of EGFR-CD533 over-expression (Figure 4A, right lanes). The basal Tyrphosphorylation levels of EGFR were reduced to $12-20 \%$ and $75-96 \%$ (range in three independent experiments) in U-87 MG and U-373 MG cells after transduction with Ad-EGFR-CD533 relative to AdLacZ controls (Figure 4B, top lanes), without effecting basal EGFR-protein levels (Figure 4B,

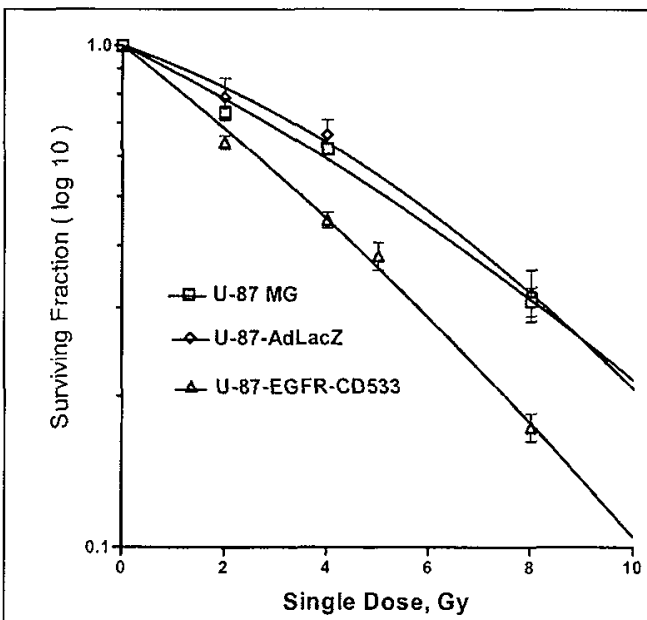

Figure 5

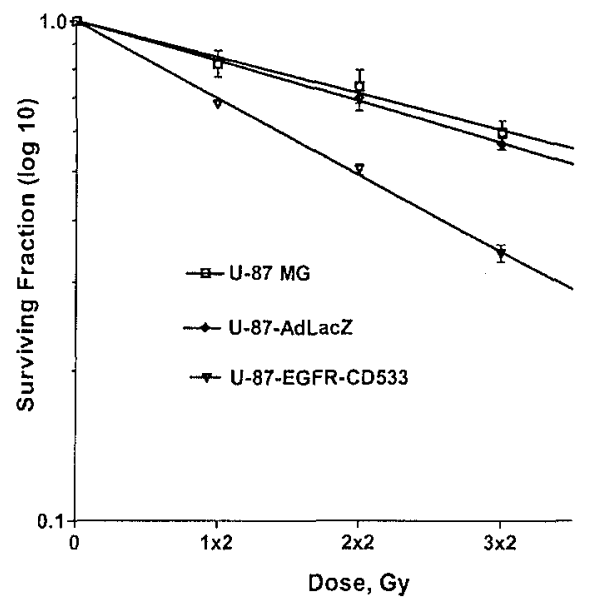

Figure 6

Figure III.1.5. Clonogenic survival after varying doses of single radiation exposure. Cells were either transduced with AdLacZ or Ad-EGFR-CD533 with an MOI of 10 for U87 or left untransduced, 48 hours later irradiated followed by a further incubation for 24 hours at $37^{\circ} \mathrm{C}$ with $5 \%$ CO2 before trypsinization and plating for clonogenic survival. After 12-14 days incubation, colonies were stained and those with $\geq 50$ cells were counted to determine the surviving fraction. The log survival was formed to the number of cells plated, after correcting for plating efficiency. The error bars represent the mean \pm SEM in three experiments.

Figure III.1.6. Clonogenic survival after repeated radiation expostures of $2 G y$ for three consecutive days. Cells were treated as described in legend of Figure 5; 48 hours later irradiated with a single dose of $2 G y$ followed by incubation for 24 hours before next irradiation with $2 G y$. Radiation was performed three times. 24 hours after each radiation exposure, cells were harvested and plated for clonogenic survival (Figure 5 legend and "Material and Methods"). The error bars represent the mean \pm SEM in three experiments.

bottom lanes). Figure $4 \mathrm{C}$ illustrates the expression levels of EGFR-CD533 compared to EGFR at the time of radiation exposure 48 hours after transduction. The expression level of the newly expressed EGFR-CD533 was substantially higher than the expression of the endogenous wild-type EGFR. This data supports previously published data on stably transfected MDA-MB-231 mammary 
carcinoma cells (13), demonstrating that the expression of EGFR-CD533 almost completely inhibits EGFR function.

\section{III.1.3.5. In vitro radiosensitivity of U-87 MG and U-373 MG cells under conditions of EGFR- CD533 expression}

To assess the effect of inhibition of EGFR function through over-expression of EGFR-CD533 on the radiosensitivity of malignant glioma cells, we examined the single dose-response colony formation assay. As shown in Figure 5, U-87 MG cells transduced with Ad-EGFR-CD533 were more radiosensitive over a range of radiation doses compared to the AdLacZ control or untransduced cells. The dose for a survival of $37 \%$ (D37) in the U-87-EGFR-CD533 cells was 1.4to 1.5-fold lower relative to transduction with AdLacZ or untransduced U-87 MG cells. This effect was amplified in repeated radiation exposure experiments, $3 \times 2 \mathrm{~Gy}$, yielding a D37 ratio of 1.8 to 2.0 in comparison to controls (Figure 6). This reduced clonogenic survival for cells expressing EGFR-CD533 was similar in the U-373 MG cells with a $38 \%$ survival reduction after a single dose of 4 Gy $(P<0.0001 ;$ Figure 7$)$.

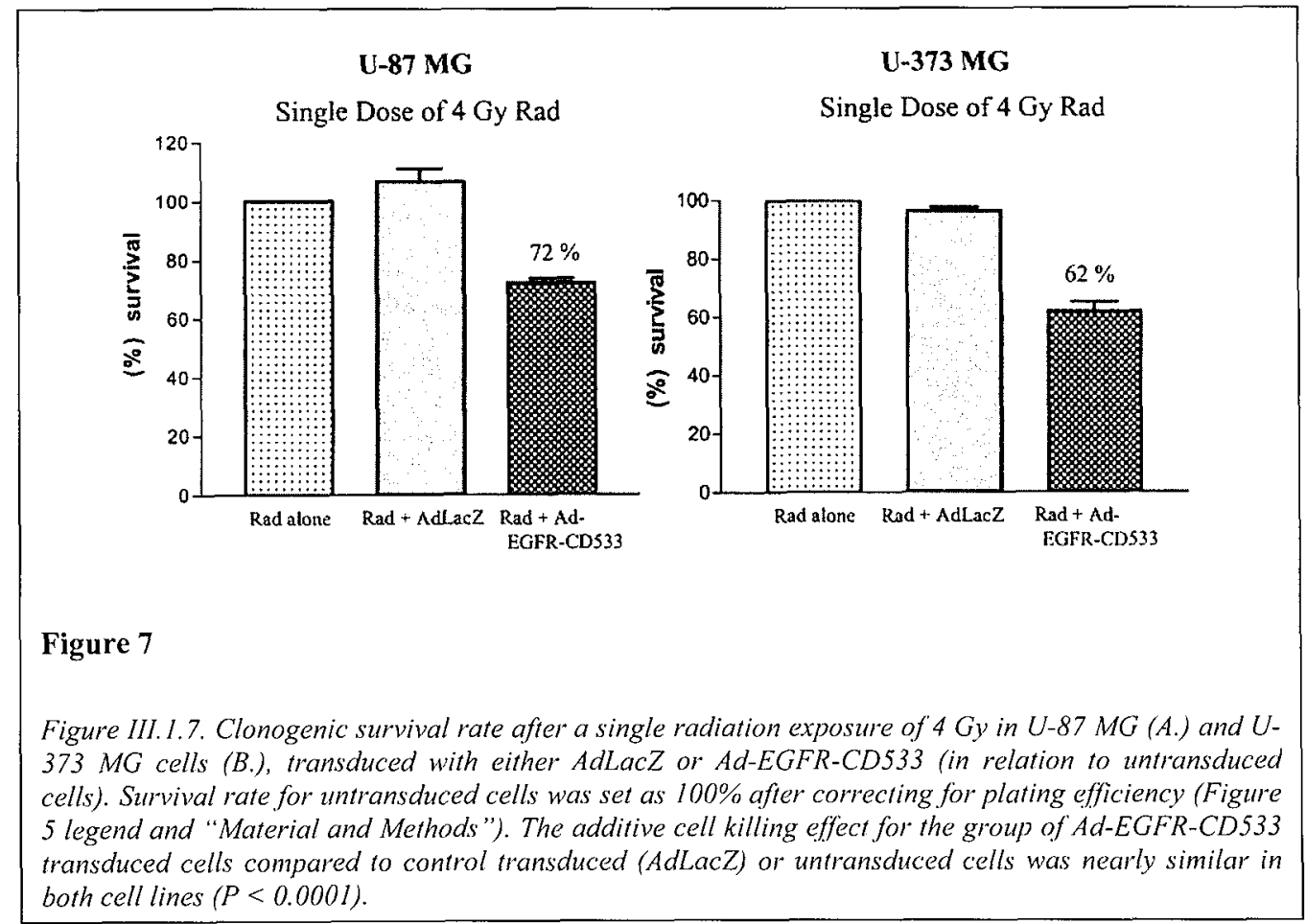




\section{III.1.3.6. In vivo radiosensitization in U-87 MG tumor xenografts after Ad-EGFR-CD533 infusion.}

To determine the effect of EGFR-CD533 on tumor radiosensitization, U-87 MG tumor xenografts measuring 8 to $10 \mathrm{~mm}$ in diameter were infused in vivo with AdLacZ or Ad-EGFR-CD533 as described in "Material and Methods". This technique routinely yielded transduction efficiencies of 59 to $65 \%$ (data not shown), as determined by x-gal staining of single cells, derived from tumor digests 3 days after AdLacZ infusion. Irradiation was performed three days after Ad infusion as described. In this study, 3 fractions of 3 Gy were used based on the in vitro studies showing enhanced radiosensitization with Ad-EGFR-CD533 transduction after repeated radiation exposures (Figure 6). Twenty-four h post-irradiation, tumors were digested to single cell suspension and ex vivo clonogenic survival was the treatment end point. The results presented in Figure 8 show that the treatment with Ad-EGFR-CD533 and radiation resulted in a $44 \%$ survival reduction relative to the control treatment with $\mathrm{AdLacZ}$ and radiation (10.4 vs. $18.5 \%$ survival; dose enhancement ratio 1.8; $\mathrm{P}<0.001)$. The plating efficiencies of tumor cells from AdLacZ- and Ad-EGFR-CD533infused tumors were similar (6.79 vs. $6.14 \%, \mathrm{p}>0.5)$.

\section{III.1.4. Discussion}


Our experimental results will be discussed in the context of using over-expression of EGFR-CD533 for the radiosensitization of human malignant glioma cells. This follows our previous findings that radiation at doses between 0.5 and 5 Gy activates EGFR in squamous and mammary carcinoma cell lines $(9,10,14)$ and mediates a cytoprotective proliferative response counteracting the toxic effects of radiation (13). Considering the extreme radioresistance of malignant gliomas (24) accelerated proliferation may be one contributing mechanism to this resistance, in part supported by encouraging improvements in tumor control rates using an accelerated dose escalation radiotherapy regimen (25). The approach of glioma cell radiosensitization by over-expression of EGFR-CD533

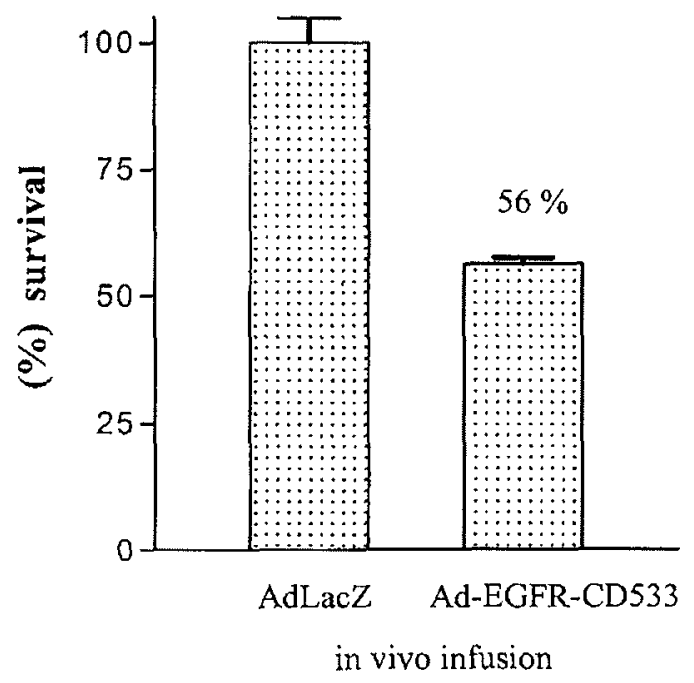

\section{Figure 8}

Figure III.1.8. Radiosensitization of U-87 MG tumor xenografts after infusion of $A d-E G F R-C D 533$. U-87 $M G$ tumor xenografts with maximum diameters of $81010 \mathrm{~mm}$ were treated with recombinant $A d L a c Z$ or Ad-EGFR-CD533 delivered intratumorally as described in "Material and Methods". At $72 \mathrm{~h}$ post-infusion, animals were irradiated with $3 \mathrm{~Gy} /$ day for 3 days at a dose rate of $2 \mathrm{~Gy} / \mathrm{min}$ using $a^{60} \mathrm{Co}$ source. At $24 \mathrm{~h}$ post-radiation, tumors were excised, digested to single cell suspension (see "Material and Methods" for details) and cells were plated for clonogenic survival. Survival rate for AdLacZ infused tumor cells was set as 100\% after correcting for plating efficiency (Figure 5 legend and "Material and Methods"). The results represent data from two independent experiments performed in quadruplicate; error bars provide \pm S.E.M. Means are significantly different $(t=10.84 ; p<0.0001)$. The dose enhancement ratio reaches 1.8 .

was justified by our finding that the two malignant glioma cell lines, U-87 MG and U-373 MG, both expressed significant levels of EGFR and ErbB2 in comparison to the squamous carcinoma cell line A-431. The functional importance of these ErbB receptors was demonstrated by their 
radiation-induced activation similar to that in other cell systems $(6,9,10,13)$, and the finding that EGFR activation was linked to the stimulation of MAPK (G. Lammering et al., unpublished results; 11). In this report we demonstrate that specific disruption of EGFR function under conditions of over-expression of EGFR-CD533 after Ad transduction results in significant radiosensitization of both human glioma cell lines and U-87 MG xenografts. Importantly, the radiosensitization of glioma cells was seen after single dose exposures, resulting in an enhancement ratio of 1.5 , and an even greater value of 2.0 , after 3 consecutive 2 Gy exposures.

Transduction of both U-87 MG and U-373 MG glioma cells with Ad-EGFR-CD533 results in massive over-expression of the DN receptor (Figure $4 \mathrm{C}$ ). This suggests that the mechanism of action of EGFR-CD533 is at the protein level similar to that previously described $(11,13)$ due to preferred dimerization of EGFR-CD533 with EGFR wild-type and other ErbB receptors, thus seriously compromising their ability for intracellular signaling. The functional implications of disrupting the radiation-induced activation of EGFR with EGFR-CD533 in glioma cell responses are presently examined in more detail. According to our previous findings in other human carcinoma cell lines, signaling along the MAPK and JNK1 are important candidate pathways in cellular radiation response (11) and have already been partially verified in glioma cells (G. Lammering et al, unpublished). In addition, we will extend our radiobiological studies to the EGFR-mediated modulation of PI-3-kinase, which also plays a critical role in cellular radiation responses $(26,27$, J. Contessa et al., unpublished).

The mechanisms underlying radiosensitization are still incompletely understood. The linkage between radiation-induced EGFR activation and proliferation represents one potential mode, which is completely eliminated by the over-expression of EGFR-CD533. This contribution of radiationinduced proliferation to radiosensitization is most directly demonstrated by repeated radiation exposure experiments $(10,11,13,14)$. Another contributing factor may act through the inhibition of MAPK cascade and other cytoplasmic protein kinases, which control many transcription processes associated with cell proliferation and repair, which are indirectly linked to enhanced biosynthetic processes $(28,29,30)$. The cellular radiation responses are additionally facilitated by altered control of cell cycle checkpoints. For example, delays in G1-S and G2-M transitions may be interpreted as the cells' intent of providing improved conditions or additional time for DNA damage repair $(27,31)$. These conclusions are increasingly supported by direct experimental evidence provided by the links between EGFR/MAPK activation and the induction of the cyclin-dependent kinase inhibitor p21WAF/CIP1 $(27,32)$. 
This radiosensitizing effect is at variance with one of our previous reports on stably transfected MDA-TR15-EGFR-CD533 mammary carcinoma cells in which no radiosensitization after single radiation exposures was observed (13). This radiosensitization occurred only under conditions of 24 h delayed plating. Previously negative radiosensitization experiments on cells irradiated in suspension immediately after trypsinization further underlines the importance of intact EGFR/ErbB RTK function in the radiation response of carcinoma and glioma cells.

Currently different approaches of inhibiting EGFR function for radiosensitization are investigated. Tyrphostin and other Tyr kinase inhibitors directed at individual or all $(10,33,34)$ ErbB receptors have shown effectiveness in carcinoma cell radiosensitization. Another major area of research concentrates on mAbs against EGFR; $\mathrm{C} 225$ being the best characterized and most widely applied one. This $\mathrm{C} 225 \mathrm{mAb}$ has been shown to radiosensitize human and murine carcinoma cells both in vitro and vivo after single and repeated radiation exposures $(35,36)$. Relative to the pharmacological and immunotherapeutic approaches the genetic therapy strategy demonstrated here has the advantage that the over-expression of DN-EGFR-CD533 likely affects all ErbB receptors irrespective of their varied expression levels by different carcinoma cells (Schmidt-Ullrich et al., unpublished), including receptors with truncated NH-terminal domains, e.g. EGFRvIII $(37,38)$, thus lacking GF and mAb binding moieties.

In summary, this report demonstrates that human glioma cells express significant but varied levels of EGFR and ErbB2. The radiation-induced activation of these receptors was almost completely inhibited by the over-expression of EGFR-CD533 after infection of cells with the adenoviral vector. The over-expression of EGFR-CD533 resulted in marked radiosensitization in vitro and in vivo as demonstrated by significantly enhanced cytotoxicity after single or repeated radiation exposures. The results presented strongly suggest that over-expression of EGFR-CD533 may be developed into a genetic therapy approach of radiosensitizing human gliomas in which EGFR and other ErbB RTKs are part of the autocrine growth regulatory circuit. 


\section{III.1.5. References}

1. Weinberg RA: Oncogenes and the Molecular Origin of Cancer. Cold Spring Harbor Laboratories Press, Cold Spring Harbor, 1989.

2. Baselga J, Mendelsohn J. The epidermal growth factor receptor as a target for therapy in breast carcinoma. Breast Cancer Res. Treat., 29: 127-138, 1994.

3. Tang P, Steck PA, Yung WKA. The autocrine loop of TGF-a/EGFR and brain tumors. J. Neurooncol., 35: 303-314, 1997.

4. Schmidt-Ullich RK, Dent P, Grant S, Mikkelsen RB, Valerie K. Signal transduction and cellular radiation responses. Radiat Res, 153:245-257, 2000.

5. Nagane M, Coufal F, Lin H, Bögler O, Cavenee WK, Su Huang HJ. A common mutant epidermal growth factor receptor enhanced tumorigenicity on human glioblastoma cells by increasing proliferation and reducing apoptosis. Cancer Res., 56: 5079-5086, 1996.

6. Schmidt-Ullrich RK, Contessa JN, Dent P, Mikkelsen RB, Valerie K, Reardon DB, Bouwers G, Lin PS. Molecular mechanisms of radiation-induced accelerated repopulation. Radiat. Oncol. Investig., 7 : 321-330, 1999.

7. Moscatello DK, Holgado-Madruga M, Godwin AK, Ramirez G, Gunn G, Zoltick PW, Biegel JA, Hayes RL, Wong AJ. Frequent Expression of a mutant growth factor receptor in multiple human tumors. Cancer Res., 55: 5536-5539, 1995.

8. Moscatello DK, Montgomery RB, Sundareshan P, McDanel H, Wong MY, Wong AJ. Trans-formation and altered signal transduction by a naturally occurring mutant EGF receptor. Oncogene, 13: 85-96, 1996.

9. Schmidt-Ullich RK, Valerie K, Fogleman PB, Walters J. Radiation-induced autophosphorylation of epidermal growth factor receptor in human malignant mammary and squamous epithelial cells. Radiat Res., 145: 79-83, 1996.

10. Schmidt-Ullrich RK, Mikkelsen RB, Dent P, Todd DG, Valerie K, Kavanagh BD, Contessa JN, Rorrer WK, Chen PB. Radiation-induced proliferation of the human A431 squamous carcinoma cells is dependent on EGFR tyrosine phosphorylation. Oncogene, 15: 1191-1197, 1997.

11. Reardon DR, Contessa JN, Mikkelsen RB, Valerie K, Amir C, Dent P, Schmidt-Ullrich RK. Dominant negative EGFR-CD533 and inhibition of MAPK modify JNK1 activation and enhance radiation toxicity of human mammary carcinoma cells. Oncogene, 18: 4756-4766, 1999.

12. Goldkorn T, Balaban N, Shannon M, Matsukuma K. EGF receptor phosphorylation is affected by ionizing radiation. Biochem. Biophys. Acta., 1358: 289-299, 1997.

13. Contessa JN, Reardon DB, Todd D, Dent P, Mikkelsen RB, Valerie K, Bouwers GD, Schmidt-Ullrich RK. The inducible expression of dominant negative epidermal growth factor receptor CD533 results in radiosensitization of human mammary carcinoma cells. Clin. Cancer Res., 5: 405-411, 1999.

14. Kavanagh BD, Lin PS, Chen P, Schmidt-Ullrich RK. Radiation-induced enhanced proliferation of human squamous cancer cells in vitro: A release from inhibition by epidermal growth factor. Clin. Cancer Res., I: 1557-1562, 1995.

15. Redemann N, Holzmann B, Rueden TV, Wagner EF, Schlessinger J, Ullrich A. Anti-oncogenic activity of signaling-defective epidermal growth factor receptor mutants. Mol Cell Biol., 12: 491-498, 1992.

16. Russell SJ, Ye YW, Waber PG, Shuford M, Schold SJ, Nisen PD. p53 mutations, O6-alkylguanine DNA alkyltransferase activity to procarbazine in human brain tumors. Cancer, 75: 1339-1342, 1995

17. Chen J, Willingham T, Shuford M, Bruce D, Rushing E, Smith, Y, Nisen PD. Effects of ectopic overexpression of $\mathrm{p} 21$ (WAF1/CIP1) on aneuploidy and the malignant phenotype of human brain tumor cells. Oncogene, 13: 1395-1403, 1996.

18. Valerie K. Viral Vectors for Gene Delivery, In: Wu-Pong, S, Rojanasakul, Y, (eds.), Biopharmaceutical Drug Design and Development, pp. 69-142. Humana Press, Inc., 1999.

19. Valerie K, Brust D, Farnsworth J, Amir C, Taher M, Hershey C, Feden J. Improved radiosensitization of rat glioma cells with Adenovirus-expressed mutant HSV-TK in combination with acyclovir. Cancer Gene Ther., 7(6), 2000.

20. Kashles O, Yarden Y, Fisher R, Ullrich A, Schlessinger J. A dominant negative mutation suppresses the function of normal epidermal growth factor receptors by heterodimerization. Mol. Cell Biol., 11: 1454-1463, 1991. 
21. Brust D, Feden J, Farnsworth J, Amir C, Broaddus WC, Valerie K. Radiosensitization of rat glioma with bromodeoxycytidine and Adenovirus expressing HSV-TK delivered by slow positive pressure infusion. Cancer Gene Ther., 7(5), 2000.

22. Ho KC, Lin PS. Safranin O counterstaining enhances the counting of $\beta$-galactosidase-expressing cells. BioTechniques, 23: 642, 1997.

23. Hall EJ. Cell survival curves. In: Hall EJ, Ryan JD, Cox K, Papadopoulos D (eds.), Radiobiology for the Radiologist, $4^{\text {th }}$ ed., p. 41. Pennsylvania: J.B. Lippincott Company, Philadelphia, 1994.

24. Taghian A, DuBois W, Budach W, Baumann M, Freeman J, Suit H. In vivo radiation sensitivity of glioblastoma multiforme. Int. J. Radiat. Oncol. Biol. Phys., 32: 99-104, 1995.

25. Cardinale RM, Schmidt-Ulirich RK, Benedict SH, Zwicker RD, Han D, Broaddus WC. Accelerated radiotherapy regimen for malignant gliomas using stereotactic concomitant boosts for dose escalation. Radiat. Oncol. Investig., 6: 175-181, 1998.

26. Contessa JN, Valerie K, Dent P, Bouwers G, Mikkelsen RB, Schmidt-Ullrich RK. ERBB 1-4 receptor tyr kinase activation profiles and cytoprotective radiation responses of human carcinoma cells. Proceedings of the Annual Meeting of the American Association for Cancer Research, 41: 479, 2000.

27. Carter S, Auer KL, Birrer M, Fisher PB, Schmidt-Ullrich RK, Valerie K, Mikkelsen R, Dent P. Inhibition of the mitogen activated protein (MAP) kinase cascade potentiates cell killing by low dose ionizing radiation in A431 human squamous carcinoma cells. Oncogene, 16: 2787-2796, 1998.

28. Sale EM, Atkinson PP, Arnott CH, Chad JE, Sale GJ. Role of ERK1/ERK2 and p70S6K pathway in insulin signalling of protein synthesis. FEBS Lett., 446: 122-126, 1999.

29. Kawasome H, Papst P, Webb S, Keller GM, Johnson GL, Gelfand EW, Terada N. Targeted disruption of p70 (s6k) defines its role in protein synthesis and rapamycin sensitivity. Proc. Natl. Acad. Sci. USA, 95: 5033-5038, 1998.

30. Lobenhofer EK, Huper G, Iglehart JD, Marks JR. Inhibition of mitogen-activated protein kinase and phosphainostol 3-kinase activity in MCF-7 cells prevents estrogen-induced mitogenisis. Cell Growth Differ. /1: 99-110, 2000.

31. Liu Y, Martinale JL, Gorospe M, Holbrook NJ. Regulation of $\mathrm{p} 21$ WAF1/CIP1 expression through mitogen-activated protein kinase signaling pathway. Cancer Res., 56: 31-35, 1996.

32. Park J-S, Carter S, Reardon DB, Schmidt-Ullrich R, Dent P, Fisher PB. Roles for basal and stimulated p21Cip-1/WAFI/MDA6 expression and Mitogen-activated protein kinase signaling in radiationinduced cell cycle checkpoint control in carcinoma cells. Mol. Cell. Biol., 10: 4231-4246, 1999.

33. Penar PL, Khoshyomn S, Bhushan A, Tritton TR. Inhibition of epidermal growth factor-associated tyrosine kinase blocks glioblastoma invasion of the brain. Neurosurgery, 40: 141-151, 1997.

34. Rao GS, Ethier SP. Potentiation of radiation-induced breast cancer cell death by inhibition of epidermal growth factor family of receptors. Proceedings of the $41^{\text {st }}$ Annual ASTRO Meeting, 45: 162, 1999.

35. Milas L, Mason K, Hunter N, Petersen S, Yamakawa M, Ang K, Mendelsohn J, Fan Z. In vivo enhancement of tumor radioresponse by $\mathrm{C} 225$ antiepidermal growth factor receptor antibody. Clin. Cancer Res., 6: 701-708, 2000.

36. Huang SM, Bock JM, Harari PM. Epidermal growth factor receptor with C225 modulates proliferation, apoptosis and radiosensitivity in squamous cell carcinomas of the head and neck. Cancer Res., 59: 1935-1940, 1999.

37. Batra SK, Castelino-Prabhu S, Wikstrand CJ, Zhu X, Humphrey PA, Friedman HS, Bigner DD. Epidermal growth factor ligand-independent, unregulated, cell-transforming potential of a naturally occuring human mutant EGFRvIII gene. Cell. Growth Differ., 6: 1251-1259, 1995.

38. O'Rourke D, Kao GD, Singh N, Park BW, Muschel RJ, Wu CJ, Greene MI. Conversion of a radioresistant phenotype to a more sensitive one by disabling erbB receptor signaling in human cancer cells. Proc.Natl.Acad.Sci., 95: 10842-10847, 1998. 


\section{Chapter III}

III.2. An anti-erbB receptor strategy as gene therapeutic intervention to improve radiotherapy in malignant human tumours

Published in: Int. J Radiat Biol. 79: 561-568, $2003(\mathrm{IF}=2.36)$

G. Lammering, T. H. Hewit, K. Valerie,

PS. Lin, J. N. Contessa, R. K. Schmidt-Ullrich 


\section{Summary}

Purpose: We explored and quantified the therapeutic potential of using dominant- negative EGFR transduction with replication-incompetent Adenovirus (Ad-EGFR-CD533 or Ad-CD533) as a genetic approach for radiosensitization in different carcinoma and malignant glioma cell lines in vitro and in established tumour xenografts in vivo.

Material and Methods: The cell lines MDA-MB-231, A-431, U-373 MG, U-87 MG and T47D were used. The ErbB expression profiles were quantified by Western blotting. MAPK immune complex assay measured MAPK activity with or without EGFR-CD533 expression after ionizing radiation (IR). Radiosensitization was determined and quantified in vitro by colony formation assays, in vivo by use of an ex vivo - in vitro colony formation assay after intratumoural infusion of the adenoviral vectors expressing EGFR-CD533 or the control LacZ.

Results: Western blotting demonstrated widely varied expression levels of the ErbB receptors in the tested cell lines. Expression of EGFR-CD533 effectively blocked the radiation- induced activation of MAPK, leading to significant radiosensitization in vitro and in vivo.

Conclusions: The radiation-induced ErbB activation can be effectively modulated by a gene therapeutic approach of overexpressing EGFR-CD533 leading to tumour cell radiosensitization after single and repeated radiation exposures both in vitro and in vivo. 


\section{III.2.1. Introduction}

Accelerated proliferation of tumours in response to radiotherapy has been implicated as a potential source for treatment failure in the clinical setting. IR of human carcinoma and malignant glioma cells in the therapeutic dose range of 1-5 Gy indiscriminately activates the ErbB receptor tyrosine

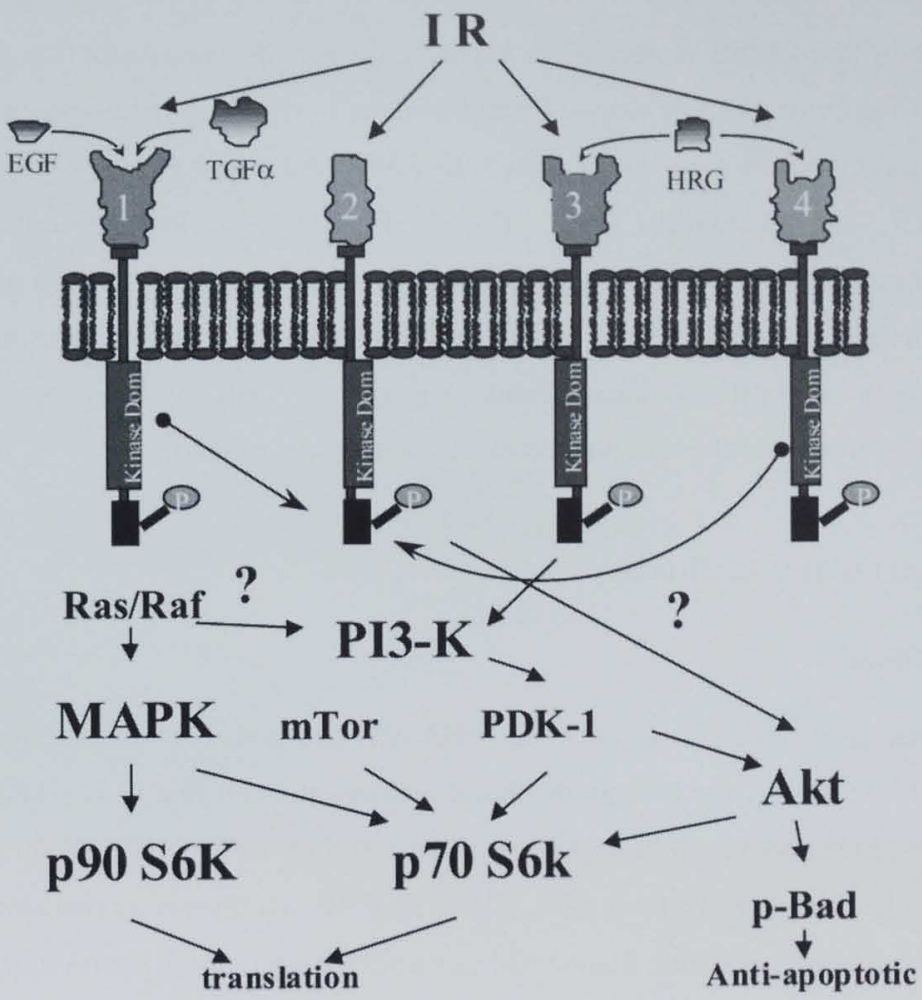

\section{Figure 1}

Figure III.2.1: Effects of ionizing radiation (IR) on ErbB- dependent existing response systems. The major cascades in ErbB-dependent radiation responses furnish cytoprotective (survival) signals after radiation exposure. The radiation-induced direct or indirect activation of the ErbB receptor tyrosine kinases results in signal transduction dominantly involving mitogen-induced protein kinase (MAPK) and the parallel pathway phosphoinositide-3-kinase (PI3K). Both stimulate $p 90$ S6K and p70 S6K, which promote transcription and post-transcriptional processes, whereas Akt also exerts anti-apoptotic effects. P90 S6K, P90 S6 kinase; p70 S6K, P70 S6 kinase.

kinase (RTK) family $(2,9,22)$. This radiation- induced activation of the ErbB RTK induces responses in cells that are currently indistinguable from receptor- specific, physiological receptor ligands. It leads to ErbB- dependent signaling dominantly involving mitogen- induced protein 
kinase (MAPK) and phosphoinositide-3-kinase (PI3K;2), which mediate proliferative and biosynthetic responses, respectively (fig. 1;1,5,6,7,21). This is most likely one mechanism underlying the radiation- induced accelerated cellular proliferation (23). The enhanced biosynthetic activity of rapidly proliferating tumour cells can be expected to increase their capacity for DNA damage repair and confer relative radioresistance. Since both of these responses counteract the toxic effects of radiation we have defined them as cytoprotective.

Considering the role of ErbB molecules in initiating these responses, disruption of ErbB function should prevent the cytoprotective responses and mediate tumour cell radiosensitization. Therefore, our research has employed a genetic approach to ErbB inhibition by overexpressing a dominantnegative EGFR, namely EGFR-CD533. This EGFR-CD533 lacks 533 amino acids of the cytoplasmic domain. It exerts its effect at the protein level through the formation of non- functional receptor complexes. We explored and quantified the therapeutic potential of using EGFR-CD533 transduction with replication- incompetent Adenovirus (Ad) as a genetic approach for radiosensitization in vitro and in established tumour xenografts in vivo.

\section{III.2.2. Material and methods}

\section{III.2.2.1. Cell lines}

The human mammary carcinoma cell lines MDA-MB-231 and T-47 D, the human epidermoid carcinoma cell line A 431, the human anaplastic astrocytoma cell line U-373 MG and U-87 MG, isolated from a glioblastoma cell line were used. All cell lines were obtained through the American Type Tissue Collection (ATCC; Rockville, MD, USA). All cell lines were maintained as described (17). Before irradiation, cells were maintained in medium with reduced serum of $0,5 \%$ FBS for 16 h $(6,21)$.

\section{III.2.2.2. Mice and tumours}

Athymic female NCr-nu/nu mice were obtained from the Animal Production Area, National Cancer Institute- Frederick Cancer Research Facility (Frederick, MD, USA). Mice were maintained under pathogen- free conditions in facilities approved by the American Association of Laboratory Animal Care and in accordance with current regulations and standards of the U.S. Department of Agriculture, the U.S. Department of Health and Human Services, both Washington, DC, and the National Institutes of Health and Human Services, Bethesda, MD, U.S.A. Solitary tumours were produced by s.c. inoculation of $10^{7} \mathrm{MDA}-\mathrm{MB}-231$ or U-87 MG cells into the right hind leg of 4- to 
6-week-old mice. Tumours derived from U-87 MG cells reached a tumour size of 7-9 mm after 3-4 weeks, whereas tumours from MDA-MB-231 cells reached the desired tumour size after 4-6 weeks.

\section{III.2.2.3. Construction of recombinant adenovirus and transduction conditions}

Replication-incompetent Ad was produced as previously described $(25,26)$. Ad-EGFR-CD533 and the control vector $\mathrm{Ad}-\mathrm{LacZ}$, expressing the bacterial lac Z reporter gene, were produced and purified by established techniques $(4,25)$. Cell lines were transduced as described $(25,26)$. Transduction efficiency was quantified $48 \mathrm{~h}$ after transduction for Ad-LacZ. Cells were stained for $\beta$-gal and counterstained with safranin $O(13)$. The number of $\beta$-galactosidase $(\beta$-gal) positive cells was quantified from a total of 500 cells (4). U-87 MG or MDA-MB-231 xenograft tumour cells were transduced by intratumoural infusion of the Ad vectors with a positive pressure infusion device (17). The Ad vector delivery was optimized under different conditions of intratumoural infusion. The most efficient transduction in vivo for MDA-MB-231 xenograft tumours was achieved with a repeated 6- track infusion on 2 consecutive days ( $2 \times 6$ ) (fig. 5; 17). U-87 MG xenograft tumour cells were efficiently transduced with only one single 6 -track infusion $(1 \times 6)$ due to the soft tumour architecture. All infusions were performed on fully anesthetized mice. Transduction efficiency for Ad-LacZ was quantified with single- tumour cell suspension, generated by digestion of the excised tumour $48 \mathrm{~h}$ after the last intratumoural infusion. The single tumour cells were stained for $\beta$ - gal and counted as described (17).

\section{III.2.2.4. Cell and tumour irradiation}

Cells were seeded at specified densities and irradiated 5 days thereafter by use of a 60 Co source (18). Cells were irradiated $48 \mathrm{~h}$ after transduction of the Ad vector as monolayers with single radiation doses between 1 and 8 Gy. For repeated radiation exposure experiments, cells were exposed once daily to 2 - or 3 Gy for 3 consecutive days. Radiation exposures in vivo started 2 days after the last infusion of the Ad vectors. The mice were placed in a plastic container and then subjected to whole-body irradiation at 1,5 Gy/ day for MDA-MB-231 tumours or $3 \mathrm{~Gy} /$ day for U$87 \mathrm{MG}$ tumours. Controls included mock irradiation of tumours infused with Ad-LacZ or AdEGFR-CD533.

\section{III.2.2.5. Western blot analysis}

Western blotting was performed as described (6). Briefly, after 5 days in culture, cells were frozen on dry ice at the time, when IR was performed for colony formation assays. The protein concentration of the lysed cells was quantified and $100 \mu \mathrm{g}$ of cell lysate were subjected to Western analysis. The nitrocellulose membranes (BioRad, Hercules, CA) were incubated with anti-EGFR, 
anti-ErbB 2, anti-ErbB 3 or anti-ErbB $4 \mathrm{mAb}$, followed by incubation with peroxidase- conjugated secondary anti-mouse mAb (2)

\section{III.2.2.6. MAPK assay}

MAPK activity was quantified by use of the immune complex assay $(17,21)$. Briefly, cell lysate aliquots with equivalent amounts of protein were incubated with an anti-ERK2 (C-14; Santa Cruz Biotechnology, Santa Cruz, CA, USA) antibody (21). The immune complexes were incubated with $20 \mu \mathrm{g}$ of a substrate protein, myelin basic protein (MBP), in the presence of [32P]- $\gamma$-ATP (5000 $\mathrm{cpm} / \mathrm{pmol}$ ) at $37 \mathrm{oC}$ for $30 \mathrm{~min}$. MBP substrate labeling with $32 \mathrm{P}$ by MAPK was measured following binding to P81 assay paper and liquid scintillation spectroscopy (21).

\section{III.2.2.7. Measures of radiation sensitivity}

In vitro radiosensitivity assays were performed 24 hours after IR (11). Cells were plated for colony formation assays and cultured for $12-17$ days. The log survival was adjusted to the number of cells plated, after correction for plating efficiency (16). Relative radiosensitivities were computed by determine the mean inactivation dose (D) and the dose for a survival of $37 \%$ (D37) for each treatment group (8). The in vivo radiosensitivity was quantified by an ex vivo clonogenic survival $(3,17)$. Mice were killed 24 hours after the last radiation fraction, tumours were excised, and singlecell suspensions were generated by digestion with an enzyme cocktail (17). The isolated single tumour cells were washed and plated in quadruplicate for colony formation.

\section{III.2.2.8. Statistical analysis}

All data presented are means \pm standard error of the mean (SEM). The dose enhancement ratios (DER's) were derived from the ratios of the mean inactivation doses (D) and from the ratios of the dose for a survival of $37 \%$ (D37) in the different experimental groups. The Student's t-test was applied for all statistical evaluations. A $\mathrm{P}<.05$ was considered to be statistically significant.

\section{III.2.3. Results}

\section{III.2.3.1. Expression levels of ErbB molecules in the examined cell lines}

The ErbB receptors are differently expressed in human carcinoma and malignant glioma cells depending on the cell line and also depending on culture conditions (10). In order to study the therapeutic potential of using EGFR-CD533 transduction with replication-incompetent Ad in a large spectrum of neoplastic cells, we performed our studies on five representative human tumour 
cell lines originating from three different tumour types. We first redefined the ErbB expression profiles for the experimental conditions and the cell lines used. As demonstrated in figure 2, the relative expression levels of the ErbB $1-4$ receptors were of widely varied intensity. As reported previously (16), the two tested malignant glioma cells express only ErbB 1 and 2. In contrast, T47 D cells rarely express any ErbB 1 but detectable levels of ErbB 4.

III.2.3.2. Radiation- induced activation of MAPK is blocked by Ad-EGFR-CD533 treatment

breast ca.

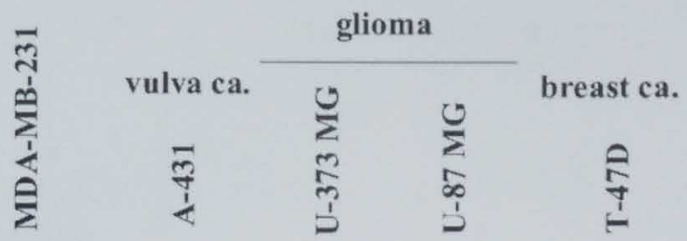

ErbB-1

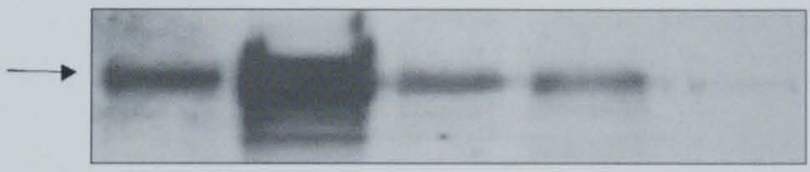

ErbB-2

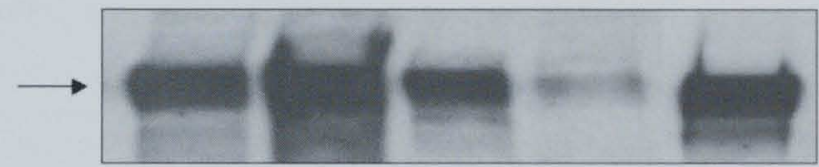

ErbB-3

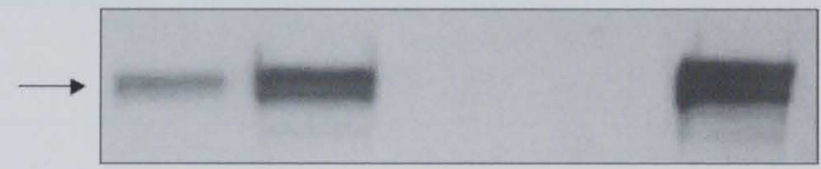

ErbB-4

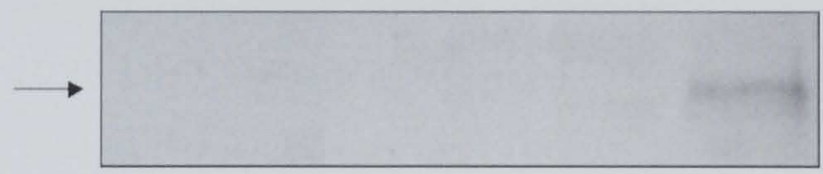

\section{Figure 2}

Figure III.2.2: ErbB protein expression profiles of the five cell lines tested for the experimental conditions used in the colony formation assays. Western blot analysis was performed for each cell line with a mAb specific for each ErbB molecule.

Having identified the optimal transduction conditions for the cells analyzed with substantial overexpression of the transgene EGFR-CD533 (18), we explored the ability of Ad-EGFR-CD533 
treatment to inhibit the radiation- induced activation of MAPK, since MAPK is an important downstream target for the radiation- induced ErbB tyrosine kinase activity $(6,21,24)$. Overexpression of EGFR-CD533 was associated with an abrogation of the radiation- induced MAPK response for the two malignant glioma cells tested (fig. 3), demonstrating similar results as previously reported for the MDA-MB-231 cells (17). Thus, treatment with Ad-EGFR-CD533 effectively blocks the ErbB- dependent radiation- induced downstream activation of MAPK most likely through trans- receptor inhibition of the ErbB receptors at the protein level (18).

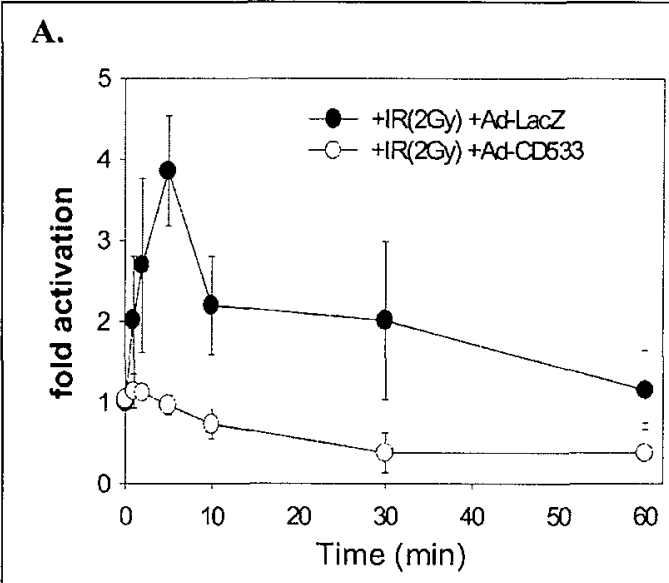

B.

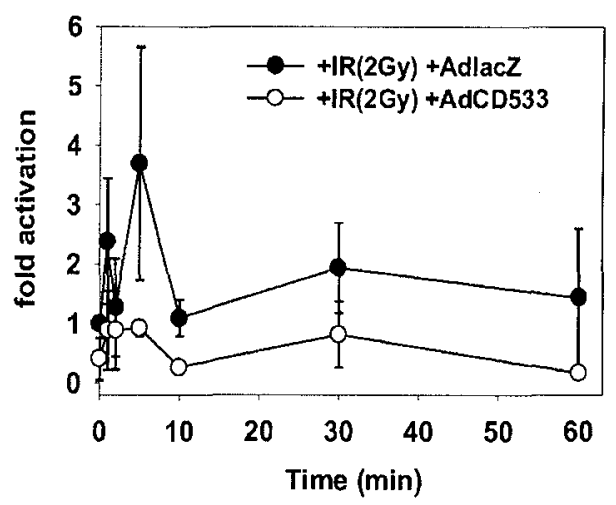

\section{Figure 3}

Figure III.2.3: Inhibition of ErbB function by Ad-EGFR-CD533 treatment completely blocks the radiation-induced activation of MAPK in U-373 MG (A) and U-87 MG cells (B). MAPK activity was quantified with immune complex assays at specified times after ionizing radiation $(I R)$ with $2 G y$ and pretreatment of the control vector $A d-L a c Z$ or $A d-E G F R-C D 533$. The corresponding values of relative $M A P K$ activity levels represent fold changes over the IR control pretreated with Ad-LacZ at 0 min.

\section{III.2.3.3. Quantification of radiosensitization after Ad-EGFR-CD533 treatment}

We further investigated whether over-expression of EGFR-CD533 could result in direct radiosensitization of a variety of different human carcinoma and malignant glioma cells, expressing quantitatively and qualitatively different profiles of ErbB receptors. The extent of radiosensitization in vitro as measured by colony formation assays was quantified after single and repeated radiation exposures. For all cell lines tested, Ad-EGFR-CD533 transduced cell lines demonstrated a significantly enhanced radiosensitivity over the range of radiation doses tested. The calculated D37 - and D- DER's are presented in figure 4 and ranged from 1.35 to 1.67 for the single dose- response experiments. Interestingly, there was a trend to amplified radiosensitization by EGFR-CD533 for repeated radiation exposures of $3 \times 2$ Gy with DER's ranging from 1.57 to 1.78. However, 
statistical comparisons between the different DER's for single and fractionated dose response experiments didn't reach significance $(\mathrm{P}=\mathrm{NS}$ ). The results demonstrate the therapeutic potential of EGFR-CD533 over- expression to achieve radiosensitization irrespective of the different ErbB receptor expression profiles.

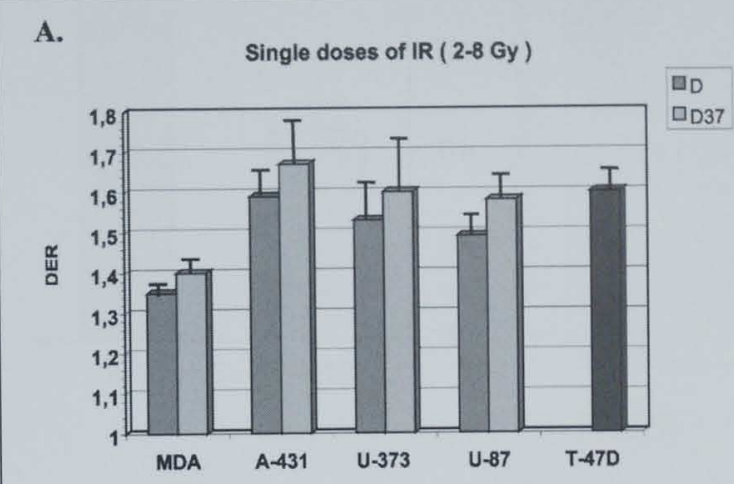

B.

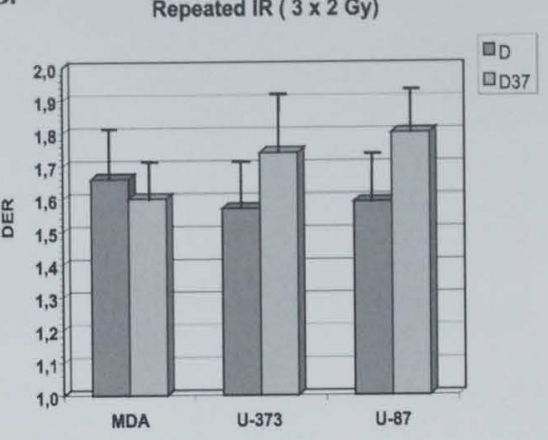

\section{Figure 4}

Figure 11I.2.4: Dose enhancement ratio's (DER's) derived from the colony formation assays performed with single $(\boldsymbol{A})$ or repeated radiation exposures $(\boldsymbol{B})$ of different carcinoma and malignant glioma cell lines treated with the control vector Ad-LacZ or Ad-EGFR-CD533. A, cells were irradiated $48 \mathrm{~h}$ after transduction at specified doses between 1 and $8 \mathrm{~Gy}$. B. cells were irradiated $48 \mathrm{~h}$ after transduction with 2 Gy for 3 consecutive days. The log survival was derived relative to the number of cells plated after correction for plating efficiency. The DER's were derived from the ratio of the mean inactivation dose (D) or the ratio of the dose for a survival of $37 \%$ (D37) in the Ad-LacZ and the Ad-EGFR-CD533 transduced

group.
* The DER for T47 D cells was derived from the ratio of the clonogenic survival after a single dose of 4 Gy. Error bars represent SEM.

We next examined in pre- clinical experiments, whether expression of EGFR-CD533 can confer radiosensitization in vivo. The tumour models used xenograft tumours, grown in nude mice. The Ad- EGFR-CD533 was infused intratumourally into established U-87 MG or MDA-MB-231 tumours by a single or repeated 6-track infusion (fig. 5A;17). The transduction efficiency was $>$ $40 \%$ in MDA-MB-231 tumours and reached $>70 \%$ in the glioma xenografts (fig. 5B). We elected to use a radiation protocol of three 1.5 Gy (MDA-MB-231) or 3 Gy (U-87 MG) exposures for 3 consecutive days. The extent of radiosensitization was quantified by ex vivo / in vitro clonogenic survival analysis (17). As demonstrated in Figure 6, the survival of Ad-EGFR-CD533 transduced tumour cells was significantly decreased compared with Ad-LacZ transduced tumour cells with nearly $50 \%$ reduction in clonogenic survival $(\mathrm{P}<0.001$; fig. $6 ; 17$ ). These results demonstrate the feasibility of using adenoviral vector- mediated gene therapy to achieve radiosensitization and the fractionated radiation regimen underlines the potential clinical relevance of these studies. 
A.

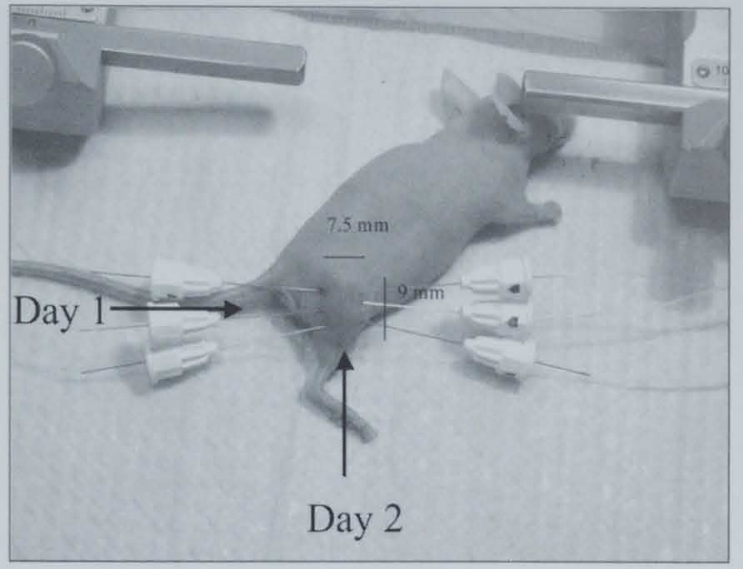

B.

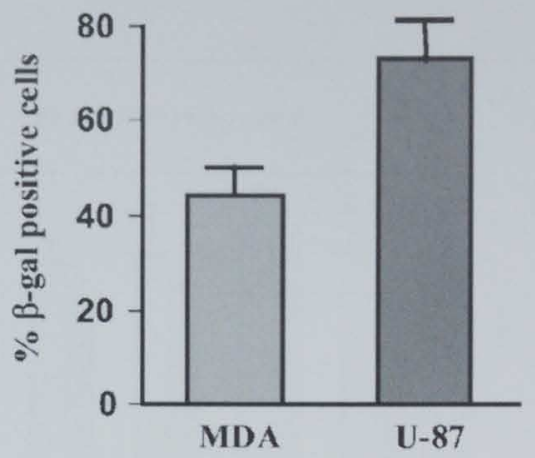

Figure 5

Figure III.2.5: Photographic representation and transduction efficiency of the intratumoural infusion technique used to transduce tumour cells in vivo with adenoviral vectors delivering the control vector Ad$L a c Z$ or the therapeutic vector Ad-EGFR-CD533. A, two sets of three needles were placed in opposing directions penetrating $60 \%$ of the tumour diameter. The $2 \times 6$ track method was repeated as a second $6-$ track infusion on day 2 with the exception, that the needles penetrated the tumour at right angles to the initial 6-track infusion (day 1). Adenoviral vectors were infused by a positive pressure-infusion device. All infusions were performed on fully anaesthetized mice. $B$, transduction efficiencies for the MDA-MB-23I (MDA) and the U-87 MG (U87) xenograft tumours after intratumoural infusion of Ad-LacZ with the $2 \times 6$ track or the $1 \times 6$ track method, respectively (see text). The transduction efficiency was quantified as the percentage of $\beta$-galactosidase positive tumour cells two days after the last infusion at the time, when repeated irradiation was started to quantify radiosensitization in vivo (see Figure 6)

\section{III.2.4. Discussion}

In summary, we present data supporting the hypothesis, that radiation-induced activation of ErbB receptors results in cytoprotective signaling, which mediate proliferative and biosynthetic responses $(1,6,15,23)$. This ErbB function can be effectively modulated by a gene therapeutic approach of overexpressing dominant-negative EGFR by use of adenoviral delivery, leading to tumour cell radiosensitization after single and repeated radiation exposures both in vitro and in vivo $(17,18)$. Our results suggest that there are at least two mechanisms contributing to the enhanced radiosensitivity after Ad-EGFR-CD533 treatment. Our results together with previous observations indicate that the enhanced radiosensitivity seen after Ad-EGFR-CD533 treatment may be explained by the elimination of a radiation- induced ErbB- dependent proliferative response $(15,23)$ as well as changes in cell cycle control and DNA repair $(6,20)$. 


\section{Figure 6}

A

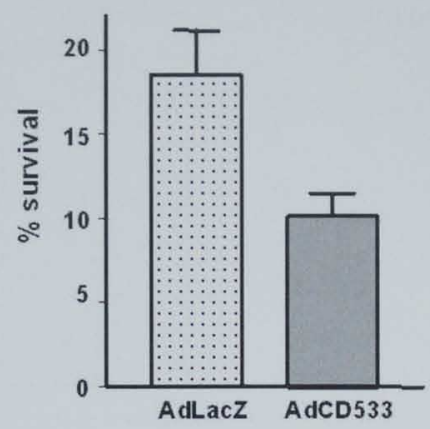

B

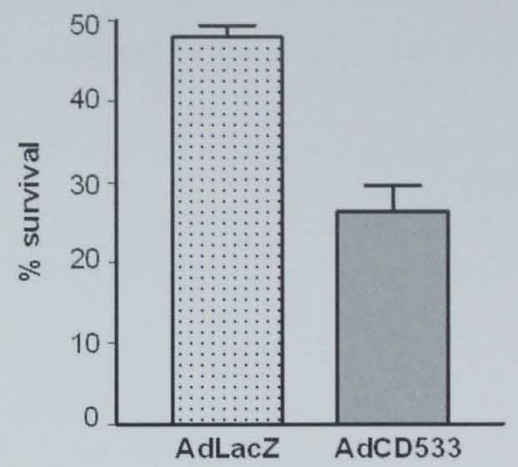

Figure 6

Figure III.2.6: Intratumoural infusion of Ad-EGFR-CD533 in vivo significantly enhances the radiosensitivity of $M D A-M B-231$ and U-87 MG tumour cells after irradiation with 1.5 or 3 Gy on 3 consecutive days, respectively. Expression of LacZ or EGFR-CD533 was induced after intratumoural infusion with $12 \times 10^{\wedge} 9$ plaque-forming units ( $p f u$ ) of adenoviral vectors by use of the $2 \times 6$ track (MDA$M B-231)$ or $1 \times 6$ track (U-87 MG) infusion protocol. Twenty-four hours after irradiation, tumours were isolated and single cells were plated in vitro for the colony formation assay. The data represents the means and standard deviations of three independent experiments (six mice / group).

The EGFR has emerged as a central molecular target for modulation in cancer therapeutics. Among the most well studied and promising current agents for EGFR signal modulation are the use of a monoclonal antibody, C225 and the selective EGFR tyrosine kinase inhibitor ZD $1839(12,19)$. Although the molecular inhibition of EGFR signaling by C225 or AG 1478 represents a highly promising investigational area, both therapeutic strategies selectively target EGFR alone, whereas EGFR-CD533 can inhibit the radiation- induced activation of all ErbB receptors by preventing functional receptor hetero-dimerization and transphosphorylation $(2,14,24)$. Until now, it hasn't been investigated whether the radiosensitizing effects of C225 might also be explained by the blockade of heterodimer formation, which would at least in part explain the lack of radiosensitization effect found by others after selective blockade of EGFR tyrosine kinase inhibition (Baumann et al., communicated).

Considering the great variation in relative expression of EGFR and the other ErbB molecules in carcinomas and malignant gliomas (fig. 3), which may substantially affect cellular responses to radiation (2), EGFR-CD533 over-expression may be a broadly active therapeutic tool applicable to different tumour types. Furthermore, current investigation in our laboratory suggests that EGFR- 
CD533 may also prove to inhibit radiation responses by other naturally occurring mutated EGFR species. The functional consequences of these mutated EGFR species on cellular radiation responses are currently being examined in more detail. In conclusion, the genetic disruption of ErbB function by expression of EGFR-CD533 represents a potential powerful tool of tumour cell radiosensitization and warrants further therapeutic evaluation. 


\section{III.2.5. References}

1. Amorino, G.P., Hamilton, V.M., Valerie, K., Dent, P., Lammering, G., Schmidt-Ullrich, R.K., 2002, Epidermal growth factor receptor dependence of radiation- induced transcription factor activation in human breast carcinoma cells. Molecular Biology of the Cell, 13, 2233-44.

2. Bowers, G., Reardon, D., Hewit, T.H., Dent, P., Mikkelsen, R.B., Valerie, K., Lammering, G., Amir, C., Schmidt-Ullrich, R.K., 2001, The relative role of ErbB1-4 receptor tyrosine kinase in radiation signal transduction responses of human carcinoma cells. Oncogene 20, 1388-97.

3. Brown, J.M., Lemmon, M.J., 1990. Potentiation by the hypoxic cytotoxin SR 4233 of cell killing produced by fractionated irradiation of mouse tumour. Cancer Research, 50, 7745-9.

4. Brust, D., Feden, J., Farnsworth, J., Amir, C., Broaddus, W.C., Valerie, K., 2000, Radiosensitization of rat glioma with bromodeoxycytidine and adenovirus expressing herpes simplex virus-thymidine kinase delivered by slow, rate-controlled positive pressure infusion. Cancer Gene Therapy, 7, 778-88.

5. Carter, S., Auer, K.L., Birrer, M., Fisher, P.B., Schmidt-Ullrich, R.K., Valerie, K., Mikkelsen, R., Dent, P., 1998, Inhibition of the mitogen activated protein (MAP) kinase cascade potentiates cell killing by low dose ionizing radiation in A431 human squamous carcinoma cells. Oncogene, 16, 278796.

6. Contessa, J.N., Reardon, D.B., Todd, D., Dent, P., Mikkelsen, R.B., Valerie, K., Bowers, G.D., Schmidt-Ullrich, R.K., 1999, The inducible expression of dominant negative epidermal growth factor receptor CD533 results in radiosensitization of human mammary carcinoma cells. Clinical Cancer Research, 5, 405-11.

7. Contessa, J.N., Hampton, J., Lammering, G., Mikkelsen, R.B., Dent, P., Valerie, K., Schmidt-Ullrich, R.K., 2002, Ionizing radiation activates Erb-B receptor dependent Akt and p70 S6 kinase signaling in carcinoma cells. Oncogene 21, 4032-41.

8. Fertil, B., Dertinger, H., Courdi, A., Malaise, E.P., 1984, Mean inactivation dose: a useful concept for intercomparison of human cell survival curves. Radiation Research, 99, 73-84.

9. Goldkorn, T., Balaban, N., Shannon, M., Matsukuma, K., 1997, EGF receptor phosphorylation is affected by ionizing radiation. Biochem Biophys Acta, 1358, 289-99.

10. Gulliford, T.J., Huang, G.C., Ouzang, X., Epstein, R.J., 1997, Reduced ability of transforming growth factor-alpha to induce EGF receptor heterodimerization and downregulation suggests a mechanism of oncogenic synergy with ErbB2. Oncogene, 15, 2219-23.

11. Hahn, G.M., Little, J.B., 1972, Plateau-phase cultures of mammalian cells: an in vitro model for human cancer. Current Topics in Radiation Research Q, 8, 39-83.

12. Harari, P.M., Huang, S.M., 2001, Radiation Response modification following molecular inhibition of epidermal growth factor receptor signaling. Seminars in Radiation Oncology 12, 21-26.

13. Ho, K.C., Lin, P.S., 1997, Safranin O counterstaining enhances the counting of $\beta$-galactosidaseexpressing cells. Biotechniques, 23, 642 .

14. Kashles, O., Yarden, Y., Fisher, R., Ullrich, A., Schlessinger, J., 1991, A dominant negative mutation suppresses the function of normal epidermal growth factor receptors by heterodimerization. Molecular and Cell Biology, 11, 1454-63.

15. Kavanagh, B.D., Lin, P.S., Chen, P., Schmidt-Ullrich, R.K., 1995, Radiation-induced enhanced proliferation of human squamous cancer cells in vitro: A release from inhibition by epidermal growth factor. Clinical Cancer Research, 1, 1557-62.

16. Lammering, G., Valerie, K., Lin, P.S., Mikkelsen, R.B., Contessa, J.N., Feden, J.P., Farnsworth, J., Dent, P., Schmidt-Ullrich, R.K., 2001 a, Radiosensitization of malignant glioma cells through overexpression of dominant-negative EGFR. Clinical Cancer Research, 7, 682-90.

17. Lammering, G., Hewit, T.H., Hawkins, W.T., Contessa, J.N., Reardon, D.B., Lin, P.S., Valerie, K., Dent, P., Mikkelsen, R.B., Schmidt-Ulirich, R.K., $200 \mathrm{lb}$, Epidermal growth factor receptor as a genetic therapy target for carcinoma cell radiosensitization. Journal of the National Cancer Institute, 93, $921-9$.

18. Lammering, G., Lin, P.S., Contessa, J.N., Hampton, J., Valerie, K., Schmidt-Ullrich, R.K., 2001c, Adenovirus- mediated over-expression of dominant negative epidermal growth factor receptor-CD533 as a gene therapeutic approach radiosensitizes human carcinoma and malignant glioma cells. International Journal of Radiation Oncology, Biology and Physics, 51, 775-84.

19. Nasu, S., Ang, K.K., Fan, Z., Milas, L., 2001, C225 antiepidermal growth factor receptor antibody enhances tumour radiocurability. International Journal of Radiation Oncology, Biology and Physics, 51, 474-7. 
20. Park, J.S., Carter, S., Reardon, D.B., Schmidt-Ullrich, R., Dent, P., Fisher, P.B., 1999, Roles for basal and stimulated p21 (Cip-1/WAF1/MDA6) expression and mitogen-activated protein kinase signaling in radiation-induced cell cycle checkpoint control in carcinoma cells. Molecular Biology of the Cell, 10, 4231-46.

21. Reardon, D.R., Contessa, J.N., Mikkelsen, R.B., Valerie, K., Amir, C., Dent, P., Schmidt-Ullrich, R.K., 1999, Dominant negative EGFR-CD533 and inhibition of MAPK modify JNK1 activation and enhance radiation toxicity of human mammary carcinoma cells. Oncogene, 18, 4756-66.

22. Schmidt-Ullrich, R.K., Valerie, K., Fogleman, P.B., Walters, J.M., 1996, Radiation-induced autophosphorylation of epidermal growth factor receptor in human malignant mammary and squamous epithelial cells. Radiation Research, 145, 79-83.

23. Schmidt-Ullrich, R.K., Contessa, J.N., Dent, P., Mikkelsen, R.B., Valerie, K., Reardon, D.B., 1999, Molecular mechanisms of radiation-induced accelerated repopulation. Radiation Oncology Investigations, 7, 321-30.

24. Schmidt-Ullrich, R.K., Dent, P., Grant, S., Mikkelsen, R.B., Valerie, K., 2000, Signal transduction and cellular radiation responses. Radiation Research, 153, 245-57.

25. Valerie, K., 1999, Viral vectors for gene therapy. In: Biopharmaceutical Drug Design and Development, edited by S. Wu-Pong and Y. Rojanasakul (Humana Press, Inc., Totowa, New Jersey).

26. Valerie, K., Brust, D., Farnsworth, J., Amir, C., Taher, M., Hershey, C., Feden, J., 2000. Improved radiosensitization of rat glioma cells with adenovirus- expressed mutant HSV-TK in combination with acyclovir. Cancer Gene Therapy, 7, 879-84 


\section{Chapter III}

III.3. Epidermal growth factor receptor as a genetic therapy target for carcinoma cell radiosensitization

Published in: J Natl Cancer Inst. 93: 921-9, 2001 (IF = 14.24)

Guido Lammering, Theodore H. Hewit, William T. Hawkins, Joseph N. Contessa, Dean B. Reardon, Peck-Sun Lin, Kristoffer Valerie, Paul Dent, Ross B. Mikkelsen, Rupert K. Schmidt-Ullrich 


\section{Summary}

Background: Exposure of human cancer cells to ionizing radiation activates the epidermal growth factor receptor (EGFR), which, in turn, mediates a cytoprotective response that reduces the cells' sensitivity to ionizing radiation. Overexpression of a dominant-negative EGFR mutant, EGFRCD533, disrupts the cytoprotective response by preventing radiation-induced activation of the receptor and its downstream effectors. To investigate whether gene therapy with EGFR-CD533 has the potential to increase tumor cell radiosensitivity, we introduced an adenoviral vector containing EGFR-CD533 into xenograft tumors in nude mice and evaluated the tumor response to ionizing radiation.

Methods: Xenograft tumors established from the human mammary carcinoma cell line MDA-MB231 were transduced via infusion with the adenoviral vector Ad-EGFR-CD533 or a control vector containing the $\beta$-galactosidase gene, Ad-LacZ. The transduced tumors were then exposed to radiation in the therapeutic dose range, and examining the tyrosine phosphorylation of immunoprecipitated EGFR assessed radiation-induced EGFR activation. Radiosensitization was determined in vitro by colony- formation assays. All statistical tests were two-sided.

Results: The transduction efficiency of MDA- MB-231 tumors by Ad-LacZ was 44\%. Expression of EGFR-CD533 in tumors reduced radiation-induced EGFR activation by 2.94-fold (95\% confidence interval $[\mathrm{CI}]=2.23$ to 4.14$)$. The radiosensitivity of Ad-EGFR-CD533-transduced tumors was statistically significantly higher $(46 \% ; \mathrm{P}<.001)$ than that of Ad- LacZ-transduced tumors, yielding a dose-enhancement ratio of $1.85(95 \% \mathrm{CI}=1.54$ to 2.51$)$.

Conclusions: Transduction of MDA-MB-231 Xenograft tumors with Ad-EGFR-CD533 conferred a dominant-negative EGFR phenotype and induced tumor radiosensitization. Therefore, disruption of EGFR function through overexpression of EGFR- CD533 may hold promise as a gene therapeutic approach to enhance the sensitivity of tumor cells to ionizing radiation. 


\section{III.3.1. Introduction}

The epidermal growth factor receptor (EGFR) and other ErbB receptor tyrosine kinases (RTKs) are involved in the autocrine growth regulation of many carcinoma cells (1-4). We have demonstrated that the exposure of tumor cells to ionizing radiation in the therapeutic dose range (i.e., 1-5 Gy) results in the immediate activation of EGFR (5-7) and that repeated radiation exposures of 2 Gy lead to increased EGFR expression ( 8 . The activation of EGFR by radiation $(5,9)$ was defined by a several-fold increase in tyrosine phosphorylation currently indistinguishable from the effects induced by the epidermal growth factor $(5,9-12)$. In addition, radiation-induced EGFR activation results in a pronounced radiation dose-dependent, proliferative response that can be quantified in vitro after both single $(10)$ and repeated $(6,13)$ radiation exposures. On the basis of these findings, we have concluded that radiation-induced EGFR activation contributes, at least in part, to the mechanism of accelerated proliferation (11,14-16). This cellular proliferation response during repeated radiation exposures, as used in clinical radiotherapy (16-18), leads to increased renewal of tumor clonogens $(16,19,20)$. In addition, the increased biosynthetic activity of rapidly proliferating tumor cells can be expected to increase their capacity for DNA damage repair. Because both the proliferative and the DNA repair responses counteract the toxic effects of radiation therapy, we have defined them as cytoprotective. Considering the role of EGFR in initiating these responses, disruption of EGFR function should prevent the cytoprotective responses and mediate tumor cell radiosensitization.

To examine the broad therapeutic potential of inhibiting EGFR activation after irradiation, we have studied the conditions for optimal radiosensitization in a spectrum of human tumor cells that are autocrine growth regulated by EGFR $(6,7,13)$. For reasons of specificity and broad applicability, we chose to inhibit EGFR through a genetic approach by overexpressing EGFR-CD533, a mutant of EGFR that lacks the entire cytoplasmic domain of 533 amino acids and confers no transformation or proliferation promoting activity $(21,22)$. EGFR-CD533 disrupts the function of the entire ErbB RTK network through receptor-protein interactions independent of the varied receptor-expression profiles seen in different tumor cells (22,23). Induction of EGFR-CD533 expression in stably transfected MDA-EGFR-CD533 mammary carcinoma cells completely blocked cytoprotective, proproliferative signalling along the EGFR/mitogen-activated protein kinase (MAPK) cascade, including the radiation-induced activation of EGFR and MAPK, and blocked the stimulation of cell proliferation $(6,13)$. These inhibitory effects are associated with marked radiosensitization of these tumor cells in vitro [(6,7); Lammering G, Lin P-S, Schmidt-Ullrich RK: unpublished data]. Because two underlying mechanisms can be expected to contribute to in vivo radiosensitivity examined in 
this study, we propose inhibition of radiation-induced proliferation and direct radiosensitization $(6,7)$.

The current studies examine, in pre-clinical experiments, whether expression of EGFR-CD533 can confer radiosensitization in vivo. The tumor models use xenograft tumors, grown in nude mice, of the human mammary carcinoma cell MDA-MB-231 and the stably transfected counterpart MDAEGFR-CD533 (6). We use a genetic therapy approach of tumor cell transduction in vivo, whereby a replication-incompetent adenoviral vector expressing EGFR-CD533, Ad-EGFR-CD533, is infused into established MDA- MB-231 tumors. The studies presented include the extent of radiosensitization conferred by EGFR-CD533 expression as quantified by ex vivo (in vivo/in vitro) clonogenic survival analyses that compare MDA-MB-231 cells isolated from tumors transduced in vivo with Ad-EGFR-CD533 with cells from MDA-EGFR-CD533 tumors, in which all of the cells are engineered to stably overexpress EGFR-CD533. The studies are complemented by immunochemical analyses and kinase assays establishing mechanistic links between inhibition of radiation-induced EGFR activation by EGFR-CD533 and tumor cell radiosensitization.

\section{III.3.2. Materials and Methods}

\section{III.3.2.1 Cell culture}

The human mammary carcinoma cell line MDA- MB-231 was obtained from the American Type Culture Collection (Manassas, VA). The MDA-TR15- EGFR-CD533 cell line, referred to as MDAEGFR- CD533, was developed in our laboratory by stably transfecting MDA-MB-231 cells with a plasmid containing the EGFR-CD533 complementary DNA (cDNA), the expression of which is under the control of a doxycycline-inducible promoter (6). Both of the cell lines were maintained in RPMI-1640 medium containing 5\% tetracycline-free fetal calf serum (RPMI/5FCS) and antibiotics (penicillin/ streptomycin), except when the cells were exposed to RPMI-1640 medium containing $0.5 \%$ FCS (RPMI/0.5FCS) before irradiation as described previously $(6,13)$.

\section{III.3.2.2. Animals and tumors}

Athymic female NCr-nu/nu mice were obtained from the Animal Production Area, National Cancer Institute-Frederick Cancer Research Facility (Frederick, MD). Mice were maintained under pathogen-free conditions in facilities approved by the American Association for Accreditation of Laboratory. Animal Care and in accordance with current regulations and standards of the U.S. Department of Agriculture, Washington, DC, the U.S. Department of Health and Human Services, Washington, DC, and the National Institutes of Health, Bethesda, MD. Single tumors were 
produced by subcutaneously injecting 107 viable MDA-MB-231 or MDA-EGFR-CD533 cells into the right hind leg of 4-to 6-week-old mice. Tumors derived from MDA-MB-231 cells reached a tumor size of 8-10 mm after 4-6 weeks, whereas tumors from MDA-EGFR-CD533 reached the desired tumor size after $12-16$ weeks. All experiments were conducted with tumors $8-10 \mathrm{~mm}$ in diameter.

\section{III.3.2.3. Generation of adenoviral vectors}

A replication-incompetent adenovirus was produced as described previously $(24,25)$. Adenoviral vectors containing EGFR-CD533 cDNA, Ad- EGFR-CD533, or the bacterial lacZ reporter gene as a control, Ad-LacZ, were produced in HEK 293 cells and purified as described previously $(25,26)$. The dominant-negative EGFR-CD533 cDNA (12) was provided by A. Ullrich (Max-PlanckInstitute for Biochemistry, Martinsried, Germany).

\section{III.3.2.4. Transduction protocols and assessment of transduction efficiency}

MDA-MB-231 cells were seeded at a density of $1.4 \times 105$ cells in $60-\mathrm{mm} 2$ dishes and were cultured in RPMI/5FCS for 5 days. On day 3, MDA-MB-231 cells were transduced with Ad-EGFRCD533 or Ad- LacZ at a multiplicity of infection (MOI) of 50 or were mock transduced with an equivalent volume of media that did not contain any adenovirus. We quantified the transduction efficiency 48 hours after transduction with Ad-LacZ by staining the cells for $\beta$-galactosidase, counterstaining with safranin $O$, and then counting the number of $\beta$-galactosidase- positive cells from a total of 500 cells $(26,27)$. The MOI was optimized for maximum transduction and minimum cellular toxicity, so that there was less than a $20 \%$ reduction in colony-formation efficiency relative to mock-transduced cells. MDA-MB-231 tumor xenografts were infused with Ad-LacZ or AdEGFR-CD533 vectors by a constant flow rate controlled at approximately $0.5 \mu \mathrm{L} /$ minute by use of a positive pressure-infusion device $(26,28)$. Initial experiments delivered the adenoviral vectors, 1010 plaque-forming units (pfu) in $0.12 \mathrm{~mL}$ of phosphate-buffered saline (PBS), over a 40 -minute period. To optimize the adenoviral vector delivery, we compared transduction efficiencies after single 4-or 6-track infusions, by the use of one 30-gauge needle/track, with repeated infusions of the 6 -track arrangement on 2 consecutive days $(2 \times 6$ track). The most efficient transduction in vivo was achieved with the $2 \times 6$-track setup that placed two sets of three needles in opposing directions that penetrated $60 \%$ of the tumor diameter. The needles were spaced evenly to achieve the widest possible distribution of adenovirus delivery within the tumor, and each needle was retracted by 1 $\mathrm{mm}$ every 10 minutes during the 40 -minute infusion. The $2 \times 6$-track method was repeated as a second 6-track infusion on the second day, with the exception that the needles penetrated the tumor at right angles to the initial 6-track infusion (see Fig. 3, B). A Bee Hive Controller and a Baby Bee 
Syringe Pump (Bioanalytical Systems, Inc., West Lafayette, IN) were used for all adenoviral infusions. All infusions were performed on fully anesthetized mice.

\section{III.3.2.5. Induction of EGFR-CD533 expression in the stably transfected MDA-EGFR-CD533} cells.

MDA-EGFR-CD533 cells were seeded at a density of $1.4 \times 105$ cells in $60-\mathrm{mm} 2$ dishes and were cultured in RPMI/5FCS for 5 days. On day 3, EGFR-CD533 expression was induced in MDAEGFR-CD533 cells with doxycycline at $1 \mu \mathrm{g} / \mathrm{mL}$ for 48 hours. EGFR-CD533 expression was assessed as described below. EGFR-CD533 expression in MDA-EGFR-CD533 tumor xenografts was induced by doxycycline injections. Two protocols were used, depending on the radiation therapy that followed. In one protocol, seven intraperitoneal injections at $0.3 \mathrm{mg}$ at $1 \mu \mathrm{g} / \mu \mathrm{L}$ of doxycycline were given approximately 12 hours apart over a 90 -hour time period. The mice were then irradiated with a 4-Gy single radiation exposure. In the second protocol, twice-daily doxycycline injections were initiated 24 hours before the first radiation exposure and were continued for the consecutive 3 days during which the tumors were irradiated with 1.5 Gy each day. Doxycyline injections continued until 20 hours after the last radiation exposure, at which time the tumors were harvested for processing to single-cell suspensions (see below).

\section{III.3.2.6. Irradiation protocols}

MDA-MB-231 and MDA-EGFR-CD533 cells were seeded at specified densities and irradiated 5 days thereafter by use of a $60 \mathrm{Co}$ source at a dose rate of $1.9 \mathrm{~Gy} /$ minute. For all experiments, cells were maintained at $37{ }^{\circ} \mathrm{C}$ except for the irradiation itself, which was performed at $20^{\circ} \mathrm{C}$. The radiosensitizing effects of EGFR-CD533 in vivo in response to ionizing radiation were tested after intratumoral infusion of Ad-EGFR-CD533 in MDA-MB-231 tumors or in MDA-EGFR-CD533 tumors after doxycycline treatment of mice. Radiation exposures in vivo started 2 days after infusion of the adenoviral vectors or were scheduled between the twice-daily doxycycline injections described above. The mice were placed in a plastic container to ensure that they would be exposed to the full radiation dose and were then subjected to whole-body irradiation at $1.5 \mathrm{~Gy} /$ day for 3 consecutive days. Controls included mock irradiation of tumors infused with Ad-LacZ or AdEGFR-CD533. For immunochemical verification of radiation- induced EGFR activation, as assessed by the extent of EGFR tyrosine phosphorylation, mice were exposed to a single wholebody radiation dose of 4 Gy. Tumors were excised 2, 5, and 10 minutes after irradiation or 10 minutes after mock irradiation, were frozen immediately in liquid nitrogen, and were processed as described below. 
Protein-expression levels of EGFR and EGFR-CD533 and EGFR tyrosine phosphorylation were quantified by immunoprecipitation and western blot analyses. MDA-MB-231 and MDA-EGFRCD533 cells were maintained in RPMI/0.5FCS for 16 hours before EGF treatment at $100 \mathrm{ng} / \mathrm{mL}$ for 5 minutes or irradiation with 4 Gy. Thereafter, cells were processed as described previously $(6,13,14)$. EGFR-CD533 analysis in tumor tissue was determined in extracts from tumors instantly frozen in liquid nitrogen after excision. Tumor tissue was pulverized in liquid nitrogen by use of a mortar and pestle (29) and immediately lysed in ice-cold lysis buffer (i.e., $25 \mathrm{mM} \beta$ glycerophosphate, $25 \mathrm{mM}$ Tris- $\mathrm{HCl}$ [pH 7.4], 10\% [vol/vol] glycerol, $1.5 \mathrm{mM}$ EGTA, $0.5 \mathrm{mM}$ EDTA, $1 \%$ Triton X-100, $1 \mathrm{mM}$ sodium orthovanadate, $1 \mathrm{mM}$ sodium pyrophosphate, $15 \mu \mathrm{g} / \mathrm{mL}$ of aprotinin, $15 \mu \mathrm{g} / \mathrm{mL}$ of leupeptin, $2 \mu \mathrm{M}$ benzamidine, and $150 \mu \mathrm{g} / \mathrm{mL}$ of phenylmethylsulfonyl fluoride). The cell suspension was passed sequentially through 16-to 21 -gauge needles to facilitate cell lysis. Cell debris was removed by centrifugation at $14000 \mathrm{~g}$ at $4{ }^{\circ} \mathrm{C}$ for 10 minutes, and the supernatants were processed for immunoprecipitations and western blot analysis for EGFR and EGFR-CD533 protein expression and for EGFR tyrosine phosphorylation as described previously $(6,13)$. Autoradiographs were quantified by use of Sigma Scan software (Jandel Scientific, San Rafael, CA) (5).

\section{III.3.2.8. MAPK Assay}

MAPK activity was quantified in MDA-MB-231 cell lysates by use of the immune complex MAPK assay (13). Briefly, lysate aliquots with equivalent amounts of protein, quantified by a Bio-Rad protein assay kit (Bio-Rad Laboratories, Richmond, CA), were incubated with an anti-ERK2 (C-14) antibody (Santa Cruz Biotechnology, Santa Cruz, CA) at $4{ }^{\circ} \mathrm{C}$ for 3 hours and washed twice with lysis buffer and once with kinase buffer (13). The immune complexes were incubated with $20 \mu \mathrm{g}$ of a substrate protein, myelin basic protein (MBP), in the presence of $[\gamma-32 \mathrm{P}]$ adenosine-5 $\gamma$ triphosphate $(5000 \mathrm{cpm} / \mathrm{pmol}) a t 37^{\circ} \mathrm{C}$ for 30 minutes, and the MBP labelling by MAPK was quantified by use of P81 assay paper and liquid scintillation spectroscopy (13).

\section{III.3.2.9. Clonogenic Survival Assay}

In vitro radiosensitivity assays were performed 48 hours after adenoviral vector transduction of MDA-MB-231 cells or doxycycline treatment of MDA- EGFR-CD533 cells. Cells were irradiated as monolayers with single radiation doses of $1,2,3,4$, and $8 \mathrm{~Gy}$, maintained in standard culture conditions for 24 hours, then detached with trypsin and plated for colony-formation assays to assess clonogenic survival (30). The number of cells plated in $60-\mathrm{mm} 2$ dishes was adjusted to yield $50-$ 300 colonies per radiation dose. Cells were cultured for 12 days, fixed in methanol, and stained with $0.5 \%$ crystal violet, and colonies containing 50 or more cells were counted to determine the 
surviving fraction of clonogenic cells. The log survival was adjusted to the number of cells plated, after correction for plating efficiency. Relative radiosensitivities were computed by determining the mean inactivation dose (D) for each treatment group (31). Survival curves were fitted by use of the linear-quadratic model (32).

\section{III.3.2.10. Ex vivo clonogenic survival assay}

The in vivo radiosensitivity of xenograft tumors was quantified by an ex vivo clonogenic survival assay (33). Mice were killed 24 hours after irradiation, tumors were excised, and single-cell suspensions were generated by digestion with $1.5 \mathrm{~mL}$ of collagenase Type IA $(280 \mathrm{U} / \mathrm{mL})$ and 1.5 $\mathrm{mL}$ of an enzyme cocktail containing deoxyribonuclease $(31 \mathrm{U} / \mathrm{mL})$, pronase $(225 \mathrm{U} / \mathrm{mL})$, and collagenase Type $1 A(3280 \mathrm{U} / \mathrm{mL})$ in a total volume of $15 \mathrm{~mL}$ of RPMI/5FCS and antibiotics. After 2-3hours of being stirred at $37^{\circ} \mathrm{C}$, the suspension was passed through a $40-\mu \mathrm{m}$ mesh filter. The isolated single cells were washed twice with PBS, counted, and plated in quadruplicate for colony formation. The data shown represent the mean values of the clonogenic survival for each tumor.

\section{III.3.2.11. Statistical analysis}

All data are shown as means and 95\% confidence intervals (CIs), unless otherwise specified. Statistical comparisons between clonogenic survival curves were carried out by use of the $F$ test. Student's $t$ test was applied for all other statistical evaluations. The radiation dose-enhancement ratio (DER) under conditions of EGFR-CD533 expression was derived from the ratio of the $D$ values for the control survival curves, Ad-LacZ for MDA-MB-231 cells or for MDA-EGFR-CD533 cells not treated with doxycycline, and the survival curves for EGFR-CD53 expressing corresponding cells in single-dose clonogenic survival assays. The DER in ex vivo clonogenic survival assays after repeated radiation exposures in vivo was derived from the fold difference in clonogenic survival for the control conditions with Ad-LacZ transduction or without doxycycline treatment, relative to Ad-EGFR-CD533 transduction or doxycycline treatment, respectively. A $\mathrm{P}<.05$ was considered to be statistically significant. All $\mathrm{P}$ values reported were two-sided. All statistical analyses were carried out with the SAS software package (version 8.0; SAS Institute, Inc., Cary, NC). 
A

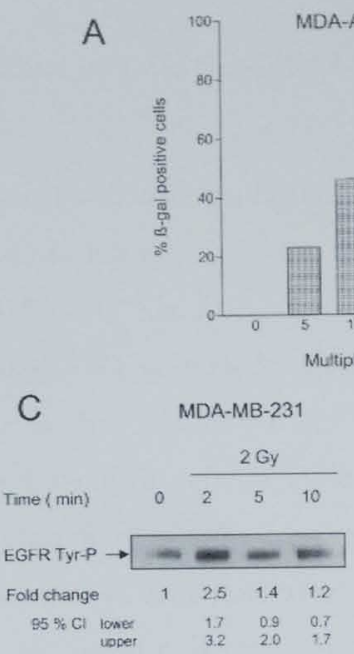

B

MDA-Ad-EGFR-CD533

D

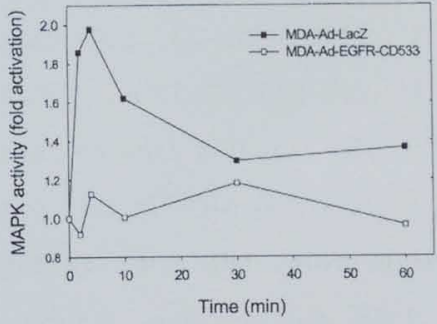

\section{Figure 1}

Fig.III.3.1. Transduction efficiency of the adenoviral vector Ad-EGFR-CD533 at increasing multiplicity of infection (MOI), kinetics of EGFR-CD533 expression, and effects of EGFR CD533 on radiationinduced epidermal growth factor receptor (EGFR) and mitogen-activated protein kinase (MAPK) activation in vitro. A) MDA-MB-231 cells were transduced with an adenoviral vector containing the bacterial LacZ gene (Ad-LacZ) at MOIs between 5 and 100. The transduction efficiency was quantified as the percentage of $\beta$-galactosidase ( $\beta$-gal)-positive cells after 48 hours. All subsequent experiments used an MOI of 50 for the transduction of cells with an adenoviral vector. B) MDA-MB-231 cells were transduced with Ad-EGFR-CD533 (MDA-Ad-EGFR-CD533). EGFR-CD533 protein-expression levels were determined by immunoblotting and compared with the level of wild-type EGFR at the indicated time points after transduction (transduction at 0 hours). C) MDA-MB-231 cells were mock transduced (MDA-MB-231) or transduced with Ad-LacZ (MDA-Ad-LacZ) or Ad-EGFR-CD533 and 48 hours later were exposed to a single radiation dose of 2 Gy or epidermal growth factor (EGF) $(100 \mathrm{ng} / \mathrm{mL})$. EGFR tyrosine phosphorylation (EGFR Tyr-P) was quantified by immunoblotting at the indicated time points after irradiation or after EGF treatment. The corresponding values of EGFR Tyr-P represent fold changes relative to the respective unirradiated control ( 0 minutes). The results shown are representative of three independent experiments. $C I$. confidence interval. D) $M D A-M B-231$ cells were transduced with $A d-L a c Z$ or Ad-EGFR-CD533 and 48 hours later were exposed to a radiation dose of 2 Gy. MAPK activity was quantified from cell lysates at the indicated times after radiation exposure. The corresponding fold increases of MAPK activity represent changes over the unirradiated respective control ( 0 minutes). The result shown is representative of two independent experiments. 


\section{III.3.3. Results}

\section{II.3.3.1. Transduction of MDA-MB-231 cells with Ad-EGFR-CD533 and radiation-induced activation of EGFR and MAPK in vitro}

To determine the susceptibility of MDA-MB-231 cells to transduction with adenovirus, we first established the optimal transduction conditions by use of the Ad-LacZ reporter virus. When MDAMB-231 cells were transduced at $60 \%-80 \%$ confluence with Ad-LacZ at an MOI of 50, the transduction efficiency was greater than $80 \%$, as determined by staining for 1 -galactosidase 48 hours after transduction (Fig. 1, A). Transduction of the MDA-MB-231 cells at an MOI of 50 yielded less than a $20 \%$ reduction in colony-formation ability relative to mock-transduced cells (data not shown). Western blot analysis of cell lysates isolated from cells transduced with AdEGFR-CD533 showed detectable levels of EGFR-CD533 expression after 24 hours that continued to increase up to 48 hours (Fig. 1, B). EGFR-CD533 protein expression levels remained high, at least up to 72 hours (data not shown). We next assessed whether a single radiation exposure could activate the endogenous EGFR in MDA-MB-231 cells transduced with the adenoviral vectors. Mock-transduced MDA-MB-231 cells had a 2.5 -fold $(95 \% \mathrm{CI}=1.7$ to 3.2$)$ increase in EGFR activation within 2 minutes of a 2-Gy radiation exposure, as determined by an increase in EGFR tyrosine phosphorylation (Fig. 1, C). MDA- MB-231 cells transduced with Ad-LacZ had a similar radiation-induced EGFR activation profile (Fig. 1, C). On the other hand, in MDA-MB-231 cells transduced with Ad-EGFR-CD533, the radiation- induced EGFR activation was completely inhibited (Fig. 1, C). We also assessed EGFR activation in response to EGF in the transduced cells. Compared with MDA-MB-231 cells transduced with Ad- LacZ, EGF-induced EGFR activation was reduced substantially in MDA-MB-231 cells transduced with Ad-EGFR-CD-533, as was the basal EGFR tyrosine phosphorylation (Fig. 1, C). Previously, we demonstrated that MAPK is an important downstream target for radiation-induced EGFR activation. Inhibition of MAPK activation by the pharmacologic inhibitor PD98059 was associated with an abrogation of the radiation-induced cellular proliferative response $(2,6)$. In addition, when MDA- EGFR-CD533 cells induced to express EGFR-CD533 were exposed to a single radiation dose of 2 Gy MAPK, activation was inhibited $(6,13)$. To assess whether transduction of MDA-MB-231 with Ad- EGFR-CD533 could inhibit radiation- induced MAPK activation, we measured MAPK activity at multiple time points after irradiation with 2 Gy. We found that MDA-MB-231 cells transduced with Ad- EGFR-CD533 had a $77 \%$ reduction in the MAPK activity 5 minutes after irradiation (Fig. 1, D). Thus, expression of EGFR-CD533 inhibits the radiation-induced activation of MAPK. 


\section{III.3.3.2. EGFR-CD533 expression and radiosensitivity in human mammary carcinoma cells} in vitro

We next examined whether the transduction of MDA-MB-231 cells with Ad- EGFR-CD533 increased radiosensitivity. The radiosensitivity of MDA-MB-231 cells that were mock transduced

A

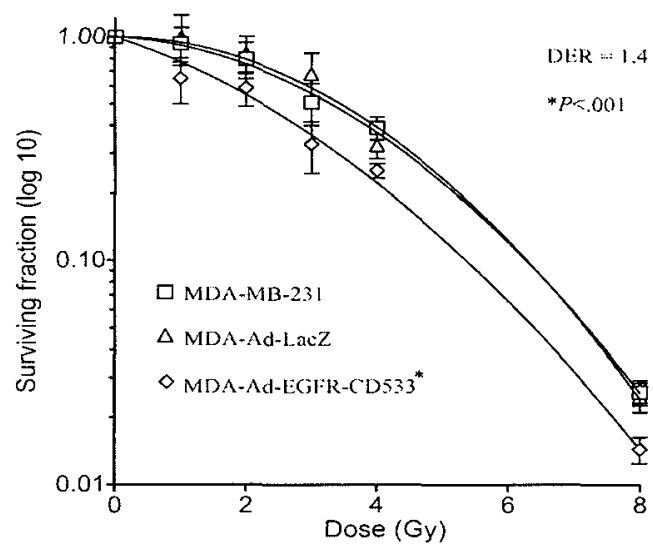

B

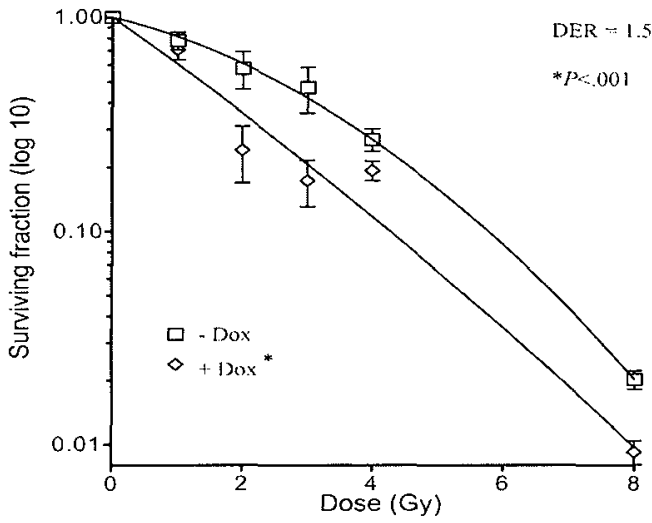

\section{Figure 2}

Fig.III.3.2. Radiation dose- response analyses of MDA-MB-23I and MDA-EGFR-CDS33 cells under conditions of EGFR-CD533 overexpression. Clonogenic survival was determined after single radiation exposures between 1 and 8 Gy. Error bars represent the means and $95 \%$ confidence intervals from four independent experiments. A) Clonogenic survival of $M D A-M B-231$ cells that were mock transduced (MDA-MB-231) or transduced with an adenoviral vector containing the LacZ gene (MDA-Ad-LacZ) or Ad-EGFR-CD533 (MDA-Ad-EGFR-CD533), both at a multiplicity of infection of 50. B) Clonogenic survival of MDA-EGFR-CD533 cells lacking expression of EGFR-CD533 (i.e., without induction by doxycycline [-Dox]) or with expression of EGFR-CD533 (i.e., with induction by doxycycline [+Dox]). $E G R F$. epidermal growth factor receptor; $D E R$. dose-enhanced ratio. 
or transduced with Ad-LacZ or Ad-EGFR-CD533 was determined in clonogenic survival assays. The survival curves yielded similar $D$ values for mock-transduced $(\mathrm{D}=3.54 ; 95 \% \mathrm{CI}=3.33$ to 3.74) and Ad-LacZ-transduced ( $\mathrm{D}=3.56 ; 95 \% \mathrm{CI}=3.29$ to 3.84) MDA-MB-231 cells. By contrast, the D value for MDA-MB-231 cells transduced with Ad-EGFR-CD533 was markedly reduced to $2.58(95 \% \mathrm{CI}=2.38$ to 2.79$)$, which was a statistically significant increase in radiosensitivity $(\mathrm{P}<.001)$ when compared with the Ad- LacZ-transduced cells $(\mathrm{DER}=1.39 ; 95 \% \mathrm{CI}=1.28$ to 1.41$)$ (Fig. 2,A). We have developed and reported on MDA-EGFR-CD533 cells that express EGFRCD533 under the control of a doxycycline-inducible promoter (6). The radiosensitivity of this stably transfected MDA-EGFR-CD533 cell line after doxycycline-induced EGFR-CD533 expression was compared with that of MDA- MB-231 cells transduced with Ad-EGFR-CD533. MDA-EGFRCD533 cells without induction of EGFR-CD533 (control cells) had a D of $2.94(95 \% \mathrm{CI}=2.81$ to 3.06), which was similar to that of mock- transduced or Ad-LacZ-transduced MDA-MB-231 cells (see Fig. 2, A [MDA-MB-231 or MDA-AdLacZ] and B [-Dox]). MDA-EGFR-CD533 cells after doxycycline-induced EGFR-CD533 expression had a D of $1.94(95 \% \mathrm{CI}=2.19$ to 1.69$)$, which yielded a DER of $1.52(95 \% \mathrm{CI}=1.34$ to 1.74$)$ and reflected a statistically significant increase in radiosensitivity relative to control cells $(\mathrm{P}<.001$; Fig. $2, \mathrm{~B})$. The radiosensitivity was similar for MDA-MB-231 cells transduced with Ad-EGFR-CD533 and MDA- EGFR-CD533 cells with doxycycline- induced EGFR-CD533 expression. Thus, these data demonstrate that EGFR-CD533 expression, whether from an adenoviral vector or from an inducible promoter in stable MDAEGFR-CD533 cells, results in direct radiosensitization of MDA-MB- 231 cells after single-dose radiation exposures.

III.3.3.3. Optimization of intratumoral infusion of Ad-EGFR-CD533 into MDA-MB-231 xenografts 
For EGFR-CD533 to be considered an effective gene therapeutic agent, it was important to determine whether the mechanism of action in vivo was similar to that seen in vitro and whether the fraction of tumor cells transduced with Ad-EGFR-CD533 would influence the radiosensitivity of tumors. To establish optimal conditions for the administration of adenoviral vectors into MDA-MB-
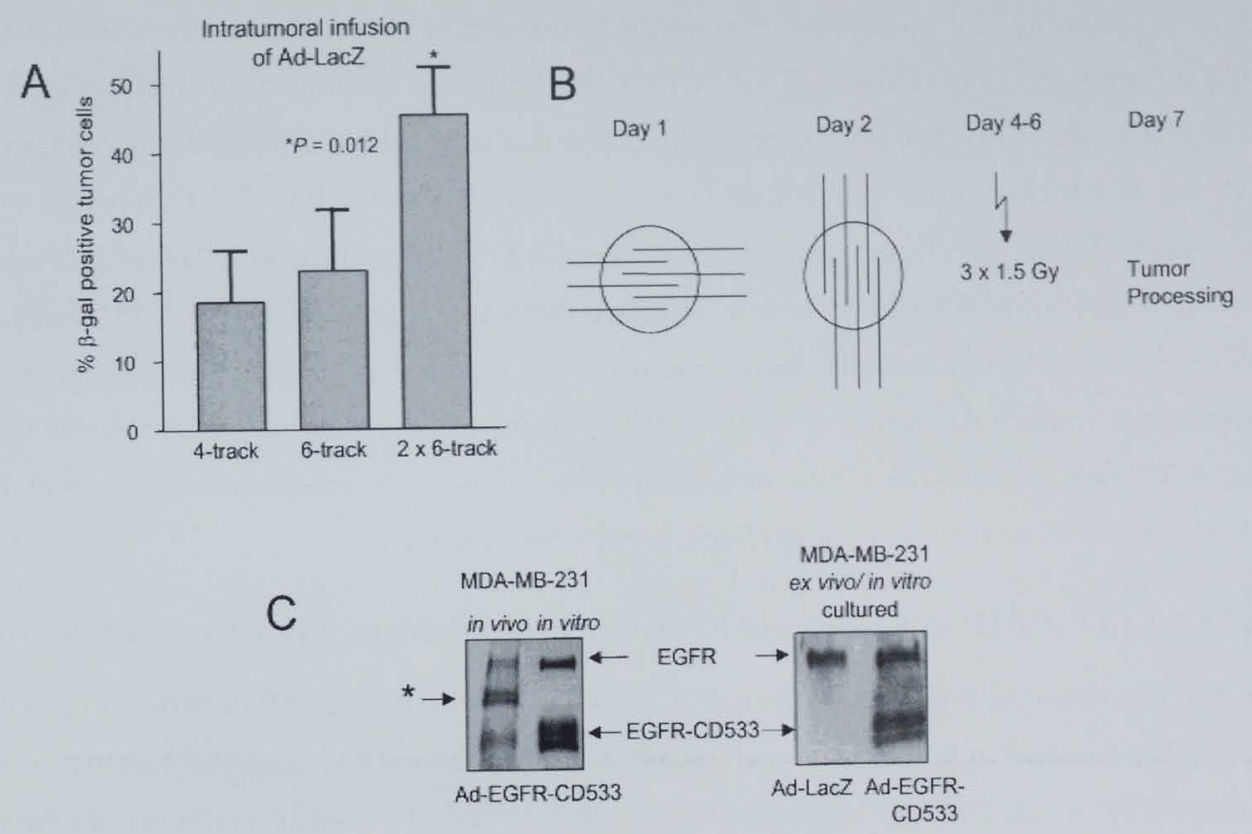

\section{Figure 3}

Fig. III.3.3. Optimization of intratumoral infusion of adenoviral vectors into MDA-MB-231 xenograft tumors and expression of EGFR-CD533 in these tumors. A) MDA-MB-231 tumors were transduced in vivo by different protocols $(4,6$, and $2 \times 6$ track) for intratumoral infusion with the same quantity (1010 plaque forming units) of an adenoviral vector containing the bacterial LacZ gene (Ad-LacZ). Tumors were isolated 48 hours after infusion, and the transduction efficiency was determined in single-cell suspensions by quantifying the percentage of $\beta$-galactosidase ( $\beta$-gal)-positive tumor cells. Data represent the mean number of $\beta$-gal-positive cells and $95 \%$ confidence intervals from three independent experiments for each infusion protocol. B) Schematic depiction of the $2 \times 6$-track treatment protocol for experiments testing the in vivo radiosensitizing effects of intratumoral infusion of the adenoviral vector $A d-E G F R-C D 533$ by use of the MDA-MB-231 xenograft tumors. The $2 \times 6$-track infusions of Ad-EGFRCD533 were performed on consecutive days, and the mice were subsequently irradiated with 1.5 Gy on 3 consecutive days $(3 \times 1.5 \mathrm{~Gy}$; days 4-6). Tumors were harvested, and single cells were generated for colony-formation assays 24 hours after the last irradiation. C) Induction of EGFR-CD533 expression in $M D A-M B-231$ tumor cells after intratumoral $2 \times 6$-track infusions of Ad-EGFR-CD533. EGFR and EGFR-CD533 levels in vivo from frozen tumor tissue were assessed by immunoprecipitation and immunoblotting and compared with the in vitro levels (left panel). EGRF and EGFR-CD533 levels were also assessed 96 hours after transfer of the isolated tumor cells to tissue culture (ex vivo/in vitro; AdLacZ versus Ad-EGFR-CD533, right panel). Western blots were probed with an anti-epidermal growth factor receptor (EGFR) monoclonal antibody. This antibody also appears to detect the constitutively active truncated EGFR (EGFRVIII) on the basis of the predicted molecular weight (*). 
231 xenograft tumors, a fixed dose of Ad-LacZ (1010 pfu) was infused into tumors by use of the 4-, 6 , or $2 \times 6$-track infusion techniques. Transduction efficiencies, as assessed by $\square$-galactosidase positivity of cells after Ad-LacZ infusion, were $18 \%(95 \% \mathrm{CI}=12.6$ to 25.8$)$ and $24 \%(95 \% \mathrm{CI}=$ 14.7 to 32.1) for the single 4-and 6-track infusions, respectively (Fig. 3, A). The transduction efficiency for Ad-LacZ after $2 \times 6$-track infusions with manual needle retraction was $44 \%(95 \% \mathrm{CI}$ $=38.4$ to 52.6) (Fig. 3, A and B), which was statistically significantly higher (P.012) than that after a single 6-track infusion. Infusion of Ad-EGFR-CD533 with the $2 \times 6$-track technique (Fig. 3, B) resulted in levels of EGFR-CD533 protein expression that were similar to those of the endogenous wild-type EGFR (Fig. 3, C). The protein levels of both EGFR and EGFR-CD533 appeared to be substantially lower in cells isolated from MDA- MB-231 tumors than in MDA-MB-231 cells transduced with Ad-EGFR-CD533 in vitro, a finding that was noted previously for A-431 squamous carcinoma cells (34). In addition, tumors transduced with Ad-LacZ or Ad-EGFR-CD533 expressed higher levels of the wild-type and EGFR-CD533 protein after maintenance in vitro for 96 hours (Fig. 3, C; right panel). The results demonstrate that intratumoral administration of Ad-EGFRCD533 can transduce tumor cells with effective transgene expression.

\section{III.3.3.4. EGFR-CD533 expression and function in human mammary carcinoma cells in vivo}

We next examined the effects of expressing EGFR-CD533 in established MDA-MB-231 xenograft tumors. We determined radiation-induced EGFR activation in vivo and generated radiation doseresponse data. Single radiation exposures of 4 Gy did not alter the level of EGFR protein but did induce activation of EGFR within 2-10 minutes, as detected by a 2.5 -fold to fivefold increase in EGFR tyrosine phosphorylation (Fig. 4, A). To determine the functional consequences of EGFRCD533 expression on radiation-induced activation of EGFR in vivo, we used MDA-EGFR-CD533 tumors because all of the tumor cells could be induced to express EGFR-CD533 after intraperitoneal doxycycline administration. After establishing the conditions for maximal induction of EGFR-CD533 expression in MDA-EGFR-CD533 tumors by repeated intra-peritoneal doxycycline injections, we compared the levels of maximum EGFR-CD533 expression in MDA-EGFR-CD533 tumors with those induced in vitro (Fig. 4, B). Of the 20 MDA-EGFR-CD533 tumors tested, greater than $80 \%$ expressed levels of EGFR-CD533 comparable to those induced in vitro, as determined by western analysis (Fig. 4, B), whereas the rest expressed intermediate or lower levels of the transgene (data not shown). Only tumors that expressed high levels of EGFR-CD533 were used for experiments to assess functional consequences of EGFR- CD533 expression. More important, radiation-induced EGFR activation was reduced by 2.94 -fold $(95 \% \mathrm{CI}=2.23$ to 4.14$)$ in doxycycline-induced MDA- EGFR-CD533 tumors (Fig. 3, B; right panel). These results demonstrate that radiation-induced EGFR activation occurred in tumors in vivo to similar extents as 
in cultured cells in vitro, and radiation-induced EGFR activation, both in vivo and in vitro, was completely inhibited by the expression of EGFR-CD533.

\section{III.3.3.5. EGFR-CD533 expression in vivo and tumor radiosensitization}

EGFR-CD533 radiosensitized MDA-MB-231 cells in vitro independent of the method of EGFRCD533 induction. These studies were then extended to examine whether in vivo expression of EGFR-CD533 could radiosensitize MDA-MB-231 tumors with the use of ex vivo clonogenic survival assays after irradiation of the tumors. Because of our previous work on radiation-induced EGFR activation and proliferation responses during repeated radiation exposures $(6,10,14)$, we elected to use a radiation protocol of three 1.5-Gy exposures for 3 consecutive days, which resulted in a $50 \%$ clonogenic survival compared with the unirradiated control tumors (data not shown). The radiosensitization of MDA- MB-231 cells after transduction with Ad- EGFR-CD533 was tested with the use of an optimized infusion and the same radiation schedule of three daily 1.5-Gy treatments (Fig. 3, B). Tumors infused with Ad-EGFR-CD533 had a statistically significant $46 \%$ reduction in clonogenic survival $(\mathrm{P}<.001)$, resulting in a DER of $1.85(95 \% \mathrm{CI}=1.54$ to 2.51 ) (Fig. 4, C) relative to $\mathrm{Ad}-\mathrm{LacZ}$ vector controls. The radiation response parameters of MDA-MB-231 tumors transduced with Ad-EGFR-CD533 were compared with MDA-EGFR-CD533 tumors in which EGFR-CD533 expression was induced in all tumor cells by repeated intra- peritoneal doxycycline administration. Clonogenic survival data corrected for plating efficiencies indicated that MDA-EGFR- CD533 tumor cells, induced to express EGFR-CD533, had a statistically significant $38 \%$ reduction in clonogenic survival $(\mathrm{P}<.001)$ compared with control tumor cells, resulting in a DER of $1.61(95 \% \mathrm{CI}=1.51$ to 1.70$)$ (Fig. $4, \mathrm{C})$. Our results demonstrate that the degree of radiosensitization was comparable between MDA-MB-231 tumors, in which $44 \%$ of the cells were transduced with Ad-EGFR-CD533, and MDA-EGFR-CD533 tumors, in which all of the cells should express EGFR-CD533 after doxycycline induction. Furthermore, the results demonstrate the feasibility of using adenoviral vector-mediated gene therapy to achieve radiosensitization. The substantial radiosensitization seen after repeated radiation exposures adds to the potential clinical relevance of these studies. 


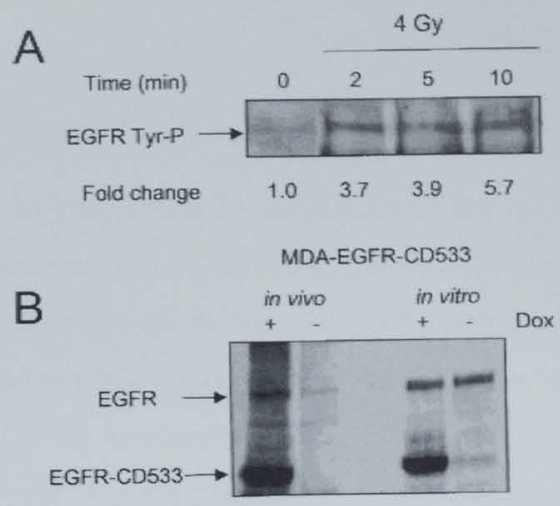

C

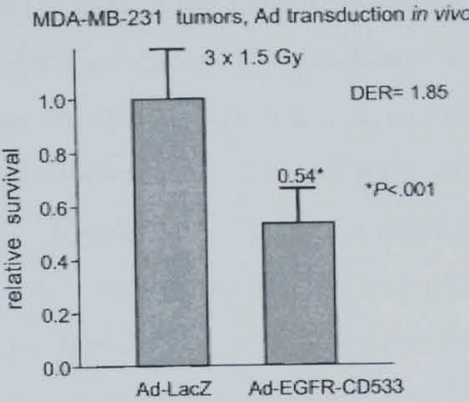

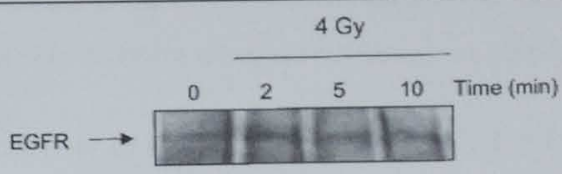

MDA-EGFR-CD533
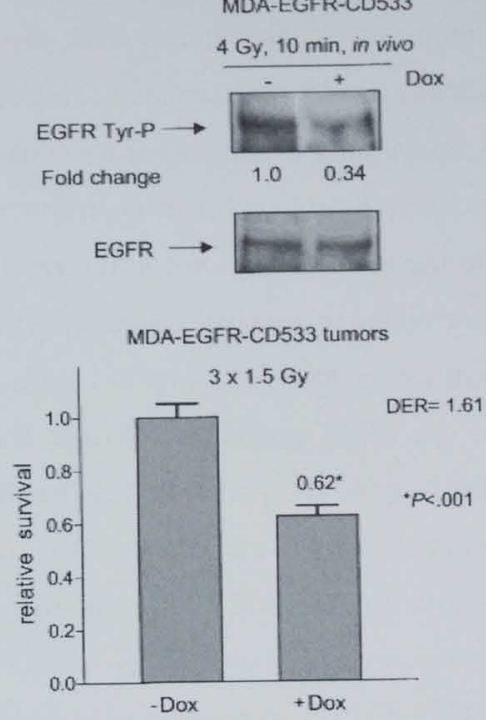

\section{Figure 4}

Fig. III.3.4. Radiation responses of epidermal growth factor receptor (EGFR) in vivo, expression and function of EGFR-CD533 in MDA-EGFR-CD533 xenograft tumors, and the effect of EGFR-CD533 expression in vivo on tumor radiosensitization. A) $M D A-M B-231$ tumors were exposed to a single radiation dose of 4 Gy. EGFR tyrosine phosphorylation (EGFR Tyr-P) was quantified by immunoblotting at the indicated time points after irradiation. The corresponding values of EGFR Tyr-P represent increases over the individual nonirradiated control (0 minutes). Blots were also probed for EGFR protein with an anti-EGFR monoclonal antibody (MAb) to demonstrate equal loading (right panel). The data are representative of three independent experiments. B) Left panel: EGFR-CD533 protein expression levels were determined in stably transfected MDA-EGFR-CD533 cells after doxycycline (Dox) treatment (1 $\mu \mathrm{g} / \mathrm{mL}$ ) in vivo and in vitro (see the "Materials and Methods" section). Right panel: MDA-EGFR-CD533 cells without (-Dox) and with (+Dox) doxycycline-induced expression of EGFR-CD533 in vivo were exposed to a single dose of 4 Gy. EGFR Tyr-P was quantified 10 minutes after radiation exposure. Blots were also probed for EGFR protein with an anti-EGFR MAb to demonstrate equal loading. The corresponding value of tyrosine phosphorylation represents the fold change relative to the control (-Dox). The data shown are representative of three independent experiments. C) The effect of EGFR-CD533 expression in vivo on the radiosensitivity of $M D A-M B-231$ and $M D A-E G F R-C D 533$ tumors after irradiation with $1.5 \mathrm{~Gy}$ on 3 consecutive days by use of an ex vivo colony-formation assay. Left panel: Expression of LacZ or EGFR-CD533 was induced in MDA-MB-231 tumors after intratumoral infusion with 1010 plaque-forming units of adenoviral vector containing the bacterial LacZ gene (Ad-LacZ) or AdEGFR-CD533 by use of the $2 \times 6$-track infusion protocol on 2 consecutive days. Twenty-four hours after irradiation, the tumors were isolated, and single cells were plated in clonogenic survival assays. The surviving fraction of MDA-MB-231 tumor cells transduced with Ad-LacZ was set as 1.0. The data represent the means and $95 \%$ confidence intervals (CIs) of three independent experiments (six mice/group). Right panel: Expression of EGFR-CD533 was induced in MDA-EGFR-CD533 tumors after Dox treatment in vivo. The surviving fraction of MDA-EGFR-CD533 tumor cells without Dox treatment (-Dox) was set as 1.0. The data represent the means and $95 \% \mathrm{CIs}$ of four independent experiments. DER= dose-enhancement ratio. 


\section{III.3.4. Discussion}

In this report, we have presented both in vitro and in vivo evidence to show that the disruption of EGFR function through the expression of a dominant-negative EGFR-CD533 resulted in a statistically significant radiosensitization after both single and repeated radiation exposures. We demonstrate that MDA-MB-231 xenografts could be transduced by Ad- EGFR-CD533 in vivo, which resulted in radiosensitization comparable to that seen with MDA-EGFR-CD533 tumors expressing EGFR-CD533 under control of a doxycycline-inducible promoter (6). Thus, the data from our pre-clinical xenograft model provide strong evidence that genetic disruption of EGFR function represents a potentially powerful tool for tumor cell radiosensitization. The use of ex vivo experimentation allowed the in vivo effects to be quantified and the mechanisms of action previously established in vitro to be verified in vivo $(5,6,13)$. Our results suggest that there are at least two mechanisms, previously linked to the expression of EGFR-CD533 (6,7) that could contribute to radiosensitization in vivo. One mechanism is the elimination of a radiation-induced proliferative response that we described with the use of MDA-EGFR-CD533 cells in a protocol of repeated radiation exposures $(6,10)$. The other mechanism may relate to EGFR-CD533 potentially interfering with changes in cell cycle control and/or DNA repair, both of which could increase survival experiments (35). Both direct radiosensitization and inhibition of cell proliferation can be expected to increase radiosensitivity in vivo (6).

We used clonogenic survival assays to assess in vivo radiosensitization because they allow a more direct comparison of cellular radiation response data with a number of other human tumor cell lines, such as squamous cell carcinoma and malignant glioma cells, in which the in vitro radiosensitization effects of EGFR- CD533 have been quantified by clonogenic survival analyses [Lammering G, Schmidt-Ullrich RK: unpublished data; 7)]. Another reason for preferring ex vivo colony formation over the alternative tumor growth-delay assays was our observation that the expression of EGFR-CD533 in vivo was associated with tumor growth retardation (Lammering G, Lin P-S, Schmidt-Ullrich RK: unpublished data). Because the growth delay of tumor xenografts is influenced by many factors other than tumor cell properties, such as radiosensitivity in standard clonogenic expression of EGFR-CD533 in our experimental system, this assay would have seriously compromised our ability to quantify in vivo radiosensitization, one of the primary goals of this investigation. Given our focus on tumor cell radiosensitization and its underlying mechanisms related to EGFR function, ex vivo clonogenic survival assays established through the isolation of single tumor cells highly correlative data between cell survival and molecular responses $(6,7,10,13)$. Several other approaches to disable the ErbB family receptor function and to modulate tumor cell responses are being explored, including the use of a monoclonal antibody, $\mathrm{C} 225$, that binds to the 
EGF-ligand domain of EGFR, thereby preventing receptor signaling (36-38), or the use of small molecule pharmacologic inhibition of the EGFR kinase domain (39-41). Studies $(37,38,42-44)$ have demonstrated that the inhibition of EGFR or ErbB2 function sensitizes tumor cells to the toxic effects of ionizing radiation. In examining the underlying mechanisms of the EGFR blockade with C225 and the expression of EGFR-CD533, it is clear that both approaches inhibit EGFR function. There is, however, indirect evidence that the mechanism(s) of action of these two approaches is different. For example, increased expression of the cyclin-dependent kinase inhibitor p27Kip-1 may be part of the mechanism by which $\mathrm{C} 225$ reduces tumor cell growth and enhances radiosensitivity (37). By contrast, EGFR-CD533 decreases tumor cell growth and increases radiosensitivity through the inhibition of radiation-induced MAPK activation followed by increased p21Cip-1/WAF1 expression (45). Moreover, C225 and EGFR-CD533 target different functions of EGFR. Whereas both $\mathrm{C} 225$ and the tyrphostin AG1478 inhibit EGFR kinase activity, the former by promoting EGFR internalisation and degradation (46) and the latter by binding directly to the EGFR catalytic cytoplasmic domain (47), EGFR-CD533 inhibits the activation of all ErbB receptors by preventing functional receptor heterodimerization and trans-phosphorylation $(11,22,23)$. Thus, there may also be an additional therapeutic benefit for a combined treatment with EGFR-CD533 and other inhibitors of EGFR function. Because overexpressed EGFR-CD533 interacts with all ErbB receptors, it may be a broadly active therapeutic tool applicable to a variety of tumor types. Both carcinomas and malignant gliomas exhibit great variation in relative expression levels of EGFR and other ErbB RTKs $(48,49)$, which may substantially affect cellular responses to radiation $(23)$. Furthermore, EGFR-CD533 may also prove to be useful in disrupting responses by other mutated EGFR species, such as EGFRvIII [(50,51); Lammering G, Hewit TH, Contessa JN, Schmidt-Ullrich RK: unpublished data]. The expression of constitutively active EGFRvIII, which lacks the EGF amino-terminal-binding domain (50), was first described for malignant gliomas $(52,53)$ but is also found in carcinoma cell xenograft tumors (Lammering G, Hewit TH, Hawkins WT, SchmidtUllrich RK: unpublished data), affirming the notion that this receptor is expressed only in vivo $(52,53)$. The functional consequences of EGFRvIII expression on cellular radiation responses are currently unknown and are being investigated in our laboratory. In summary, our data provide evidence that EGFR function can be modulated effectively by a gene therapeutic approach of overexpressing a dominant-negative EGFR-CD533 by use of in vivo adenoviral vector delivery. This results in tumor cell radiosensitization in vitro and in vivo after single and repeated radiation exposures. The mechanisms underlying this radiosensitization involve disruption of major cytoprotective responses of radiation-induced proliferation and recovery capacity, mediated by radiation-induced activation of EGFR and MAPK. The tightly associated data from in vivo/in vitro experiments allowed us to demonstrate that the genetic disruption of EGFR function in autocrine 
growth-regulated tumor cells occurs by the same mechanisms in cultured cells as in xenograft tumors, thus affirming the therapeutic potential of this approach. 


\section{III.3.5. References}

(1) Chryssogelos SA, Dickson RB. EGF receptor expression, regulation, and function in breast cancer. Breast Cancer Res Treat 1994;29: 29-40.

(2) Ekstrand AJ, James CD, Cavenee WK, Seliger B, Pettersson RF, Collins VP. Genes for epidermal growth factor receptor, transforming growth factor and their expression in human gliomas in vivo. Cancer Res 1991;51:2164-72.

(3) Alimandi M, Romano A, Curia MC, Muraro R, Fedi P, Aaronson SA, et al. Cooperative signalling of ErbB3 and ErbB2 in neoplastic transformation and human mammary carcinomas. Oncogene 1995;10:1813-21.

(4) Westphal M, Meima L, Szonyi E, Lofgren J, Meissner H, Hamel W, et al. Heregulins and the ErbB2/3/4 receptors in gliomas. J Neurooncol 1997;35:335-46.

(5) Schmidt-Ullrich RK, Valerie K, Fogleman PB, Walters J. Radiation-induced autophosphorylation of epidermal growth factor receptor in human malignant mammary and squamous epithelial cells. Radiat Res 1996;145:81-5. (6) Contessa JN, Reardon DB, Todd D, Dent P, Mikkelsen RB, Valerie K, et al. The inducible expression of dominant-negative epidermal growth factor receptor-CD533 results in radiosensitization of human mammary carcinoma cells. Clin Cancer Res 1999;5:405-11.

(7) Lammering G, Valerie K, Lin PS, Mikkelsen RB, Contessa JN, Feden JP, et al. Radiosensitization of malignant glioma cells through overexpression of dominant-negative epidermal growth factor receptor. Clin Cancer Res 2001;7:682-90.

(8) Schmidt-Ullrich RK, Valerie KC, Chan W, McWilliams D. Altered expression of epidermal growth factor receptor and estrogen receptor in MCF-7 cells after single and repeated radiation exposures. Int J Radiat Oncol Biol Phys 1994;29:813-9.

(9) Goldkorn T, Balaban N, Shannon M, Matsukuma K. EGF receptor phosphorylation is affected by ionizing radiation. Biochim Biophys Acta 1997;1358:289-99.

(10) Kavanagh BD, Lin PS, Chen P, Schmidt- Ullrich RK. Radiation-induced enhanced proliferation of human squamous cancer cells in vitro: a release from inhibition by epidermal growth factor. Clin Cancer Res 1995; 1: 1557-62.

(11) Schmidt-Ullrich RK, Dent P, Grant S, Mikkelsen RB, Valerie K. Signal transduction and cellular radiation responses. Radiat Res 2000; 153:245-57.

(12) Carter S, Auer KL, Reardon DB, Birrer M, Fisher PB, Schmidt-Ullrich RK, et al. Inhibition of the mitogen activated protein (MAP) kinase cascade potentiates cell killing by low dose ionizing radiation in A431 human squamous carcinoma cells. Oncogene 1998;16: 2787-96.

(13) Reardon DR, Contessa JN, Mikkelsen RB, Valerie K, Amir C, Dent P, et al. Dominant negative EGFR-CD533 and inhibition of MAPK modify JNK1 activation and enhance radiation toxicity of human mammary carcinoma cells. Oncogene 1999;18:4756-66.

(14) Schmidt-Ullrich RK, Mikkelsen RB, Dent P, Todd DG, Valerie K, Kavanagh BD, et al. Radiationinduced proliferation of the human A431 squamous carcinoma cells is dependent on EGFR tyrosine phosphorylation. Oncogene 1997;15:1191-7.

(15) Schmidt-Ullrich RK, Contessa JN, Dent P, Mikkelsen RB, Valerie K, Reardon DB, et al. Molecular mechanisms of radiation-induced accelerated repopulation. Radiat Oncol Investig 1999;7:321-30.

(16) Withers HR, Taylor JM, Maciejewski B. The hazard of accelerated tumor clonogen repopulation during radiotherapy. Acta Oncol 1988; 27:131-46.

(17) Trott KR. The mechanisms of acceleration of repopulation in squamous epithelia during daily irradiation. Acta Oncol 1999;38:153-7.

(18) Tubiana M. Repopulation in human tumors. A biological background for fractionation in radiotherapy. Acta Oncol 1988;27:83-8.

(19) Begg AC. Prediction of repopulation rates and radiosensitivity in human tumours. Int J Radiat Biol 1994;65:103-8.

(20) Fowler JF. Rapid repopulation in radiotherapy: a debate on mechanism. The phantom of tumor treatment—continually rapid proliferation unmasked. Radiother Oncol 1991; 22:156-8.

(21) Redemann N, Holzmann B, von Rueden T, Wagner EF, Schlessinger J, Ullrich A. Antioncogenic activity of signaling-defective epidermal growth factor receptor mutants. Mol Cell Biol 1992;12:4918.

(22) Kashles O, Yarden Y, Fisher R, Ullrich A, Schlessinger J. A dominant negative mutation suppresses the function of normal epidermal growth factor receptors by heterodimerization. Mol Cell Biol 1991;11:1454-63. 
(23) Bowers G, Reardon D, Hewit TH, Dent P, Mikkelsen RB, Valerie K, et al. The relative role of ErbB14 receptor tyrosine kinases in radiation signal transduction responses of human carcinoma cells. Oncogene 2001;20:1388-97.

(24) Valerie K. Viral vectors for gene delivery. In: Wu-Pong S, Rojanasakul Y, editors. Biopharmaceutical drug design and development. Clifton (NJ): Humana Press; 1999. p. 69-142.

(25) Valerie K, Brust D, Farnsworth J, Amir C, Taher MM, Hershey C, et al. Improved radiosensitization of rat glioma cells with adenovirus-expressed mutant herpes simplex virusthymidine kinase in combination with acyclovir. Cancer Gene Ther 2000; 7:879-84.

(26) Brust D, Feden J, Farnsworth J, Amir C, Broaddus WC, Valerie K. Radiosensitization of rat glioma with bromodeoxycytidine and adenovirus expressing herpes simplex virusthymidine kinase delivered by slow, rate-controlled positive pressure infusion. Cancer Gene Ther 2000;7:778-88.

(27) Ho KC, Lin PS. Safranin O counterstaining enhances the counting of -galactosidase- expressing cells. Biotechniques 1997;23:642.

(28) Prabhu SS, Broaddus WC, Gillies GT, Loudon WG, Chen ZJ, Smith B. Distribution of macromolecular dyes in brain using positive pressure infusion: a model for direct controlled delivery of therapeutic agents. Surg Neurol 1998; 50:367-75; discussion 375.

(29) Dent P, Lavoinne A, Nakielny S, Caudwell FB, Watt P, Cohen P. The molecular mechanism by which insulin stimulates glycogen synthesis in mammalian skeletal muscle. Nature 1990;348: 302-8.

(30) Hahn GM, Little JB. Plateau-phase cultures of mammalian cells: an in vitro model for human cancer. Curr Top Radiat Res Q 1972;8:39-83.

(31) Fertil B, Dertinger H, Courdi A, Malaise EP. Mean inactivation dose: a useful concept for intercomparison of human cell survival curves. Radiat Res 1984;99:73-84.

(32) Hall EJ. Cell survival curves. In: Hall EJ, Ryan JD, Cox K, Papadopoulos D, editors. Radiobiology for the radiologist. 4th ed. Philadelphia (PA): Lippincott; 1994. p. 41.

(33) Brown JM, Lemmon MJ. Potentiation by the hypoxic cytotoxin SR 4233 of cell killing produced by fractionated irradiation of mouse tumor. Cancer Res 1990;50:7745-9.

(34) Mansbridge JN, Ausserer WA, Knapp MA, Sutherland RM. Adaptation of EGF receptor signal transduction to three-dimensional culture conditions: changes in surface receptor expression and protein tyrosine phosphorylation. J Cell Physiol 1994;161:374-82.

(35) Khandelwal SR, Kavanagh BD, Lin PS, Truong QT, Lu J, Abraham DJ, et al. RSR13, an allosteric effector of haemoglobin, and carbogen radiosensitize FSAII and SCCVII tumours in C3H mice. $\mathrm{Br} \mathrm{J}$ Cancer 1999;79: 814-20.

(36) Park BW, Zhang HT, Wu C, Berezov A, Zhang X, Dua R, et al. Rationally designed anti- HER2/neu peptide mimetic disables P185HER2/neu tyrosine kinases in vitro and in vivo. Nat Biotechnol 2000;18:194-8.

(37) Huang SM, Harari PM. Modulation of radiation response after epidermal growth factor receptor blockade in squamous cell carcinomas: inhibition of damage repair, cell cycle kinetics, and tumor angiogenesis. Clin Cancer Res 2000;6:2166-74.

(38) Milas L, Mason K, Hunter N, Petersen S, Yamakawa M, Ang K, et al. In vivo enhancement of tumor radioresponse by $\mathrm{C} 225$ antiepidermal growth factor receptor antibody. Clin Cancer Res 2000;6:701-8.

(39) Lenferink AE, Simpson JF, Shawver LK, Coffey RJ, Forbes JT, Arteaga CL. Blockade of the epidermal growth factor receptor tyrosine kinase suppresses tumorigenesis in MMTV/Neu + MMTV/TGF-alpha bigenic mice. Proc Natl Acad SciUSA 2000;97:9609-14.

(40) Peus D, Vasa RA, Meves A, Beyerle A, Pittelkow MR. UVB-induced epidermal growth factor receptor phosphorylation is critical for downstream signaling and keratinocyte survival. Photochem Photobiol 2000; 72: 135-40.

(41) Fan Z, Shang BY, Lu Y, Chou JL, Mendelsohn J. Reciprocal changes in p27(Kip 1) and p21(Cip1) in growth inhibition mediated by blockade or overstimulation of epidermal growth factor receptors. Clin Cancer Res 1997; 3:1943-8.

(42) Bonner JA, Maihle NJ, Folven BR, Christianson TJ, Spain K. The interaction of epidermal growth factor and radiation in human head and neck squamous cell carcinoma cell lines with vastly different radiosensitivities. Int J Radiat Oncol Biol Phys 1994;29:243-7.

(43) Bos M, Mendelsohn J, Kim YM, Albanell J, Fry DW, Baselga J. PD153035, a tyrosine kinase inhibitor, prevents epidermal growth factor receptor activation and inhibits growth of cancer cells in a receptor number-dependent manner. Clin Cancer Res 1997;3:2099-106. 
(44) Baselga J, Norton L, Albanell J, Kim YM, Mendelsohn J. Recombinant humanized anti- HER2 antibody (Herceptin) enhances the antitumor activity of paclitaxel and doxorubicin against HER2/neu overexpressing human breast cancer xenografts. Cancer Res 1998:58: 2825-31.

(45) Park JS, Carter S, Reardon DB, Schmidt- Ullrich R, Dent P, Fisher PB. Roles for basal and stimulated p21 (Cip-1/WAF1/MDA6) expression and mitogen-activated protein kinase signaling in radiationinduced cell cycle checkpoint control in carcinoma cells. Mol Biol Cell 1999;10:4231-46.

(46) Prewett M, Rockwell P, Rockwell RF, Giorgio NA, Mendelsohn J, Scher HI, et al. The biologic effects of $\mathrm{C} 225$, a chimeric monoclonal antibody to the EGFR, on human prostate carcinoma. J Immunother Emphasis Tumor Immunol 1996;19:419-27.

(47) Levitzki A, Gazit A. Tyrosine kinase inhibition: an approach to drug development. Science 1995;267:1782-8.

(48) Alimandi M, Romano A, Curia MC, Muraro R, Fedi P, Aaronson SA, et al. Cooperative signalling of ErbB3 and ErbB2 in neoplastic transformation and human mammary carcinomas. Oncogene 1995;10:1813-21.

(49) Earp HS, Dawson TL, Li X, Yu H. Heterodimerization and functional interaction between EGF receptor family members: a new signaling paradigm with implications for breast cancer research. Breast Cancer Res Treat 1995; 35:115-32.

(50) Batra SK, Castelino-Prabhu S, Wikstrand CJ, Zhu X, Humphrey PA, Friedman HS, et al. Epidermal growth factor ligand-independent, unregulated, cell-transforming potential of a naturally occurring human mutant EGFRvIII gene. Cell Growth Differ 1995;6:1251-9.

(51) Moscatello DK, Holgado-Madruga M, Godwin AK, Ramirez G, Gunn G, Zoltick PW, et al. Frequent expression of a mutant growth factor receptor in multiple human tumors. Cancer Res 1995;55:5536-9.

(52) Bigner SH, Humphrey PA, Wong AJ, Vogelstein B, Mark J, Friedman HS, et al. Characterization of the epidermal growth factor receptor in human glioma cell lines and xenografts. Cancer Res 1990;50:8017-22.

(53) Nishikawa R, Ji XD, Harmon RC, Lazar CS, Gill GN, Cavenee WK, et al. A mutant epidermal growth factor receptor common in human glioma confers enhanced tumorigenicity. Proc Natl Acad SciUSA 1994;91:7727-31. 


\section{Chapter IV}

IV.1. EGFRvIII-mediated radioresistance through a strong cytoprotective response

Published in: Oncogene. 22: 5545-5553, $2003(\mathrm{IF}=6.74)$

Guido Lammering, Theodore H. Hewit, Kristoffer Valerie, Joseph N. Contessa, George P. Amorino, Paul Dent, Rupert K. Schmidt-Ullrich 


\section{Summary}

The constitutively active, truncated epidermal growth factor receptor, EGFRvIII, lacks the ability for epidermal growth factor (EGF) binding due to a major deletion of the $\mathrm{NH}_{2}$-terminal domain. The EGFRvIII oncoprotein confers increased tumorigenicity and is often co-expressed with wildtype EGFR in human carcinoma and malignant glioma cells grown as xenografts, but is not expressed in vitro. To explore the functional consequences of EGFRvIII expression on cellular radiation responses, we transfected Chinese hamster ovary $(\mathrm{CHO})$ cells with plasmids expressing either the mutant EGFRvIII (CHO.EGFRvIII) or the wild-type EGFR (CHO.EGFRwt). CHO cells expressing similar levels of both receptors were employed to dissect their relative role in responses to EGF and ionizing radiation. EGF treatment activated EGFRwt with no affect on EGFRvIII. In contrast, a single radiation exposure of 2 Gy resulted in a 2.8- and 4.3-fold increase in Tyr phosphorylation of EGFRwt and EGFRvIII, respectively. Downstream consequences of these radiation-induced activation responses were examined by inhibiting EGFRwt and EGFRvIII with AG1478, a specific EGFR kinase inhibitor, and determining the effects on the pro-proliferative mitogen-activated protein kinase (MAPK) and the anti-apoptotic phosphatidylinositol-3-kinase (PI3K)/AKT signaling pathways. Importantly, radiation-induced activation of EGFRvIII resulted in an immediate 8.5-fold activation of MAPK compared to a 3.5-fold activation by EGFRwt; similarly, EGFRvIII generated a 3.2-fold activation of AKT in CHO.EGFRvIII cells in contrast to an only minimum activation in CHO.EGFRwt cells. Colony formation and apoptosis assays verified that the presence of EGFRvIII expression enhanced the relative radioresistance of cells. These results indicate that the presence of EGFRvIII confers a stronger radiation response than EGFRwt via the cytoprotective MAPK and PI3K pathways. These dominant signals by EGFRvIII can be expected to furnish a more pronounced cytoprotective response to radiation than wild-type receptor leading to potentially greater radioresistance. Therefore, EGFRvIII expression by tumor cells needs to be considered in any therapeutic approach aimed at disabling EGFR function for tumor cell radiosensitization. 


\section{IV.1.1. Introduction}

Overexpression of EGFR in autocrine growth regulated carcinoma and malignant glioma cells is associated with the expression of mutated EGFR species as part of neoplastic progression $(10,12,19,21,22)$. Among these EGFR variants, the 140 to $155 \mathrm{kD}$ EGFRvIII represents a relatively well-characterized oncoprotein with a major in-frame deletion involving exxons 2 through 7 of the EGFR gene. Thus, the mutation eliminates most amino acids comprising subdomains I and II including the cystine-containing EGF binding site $(2,22)$. EGFRvIII is constitutively active, cannot bind EGF (20), and is only minimally activated by EGF (31). EGFRvIII is widely expressed in malignant glioma and carcinoma cells, including breast carcinoma, non-small cell lung carcinoma, ovarian carcinoma and others $(10,19)$. Mechanistic studies to elucidate the unique functions of EGFRvIII have been limited by the fact that this receptor is only expressed in vivo and is rapidly down-regulated in cultured tumor cells precluding detailed investigation (3). To date, most studies on EGFRvIII have focused on the definition of its transforming activity and its effects on downstream signal transduction pathways $(12,17)$. However, the role of EGFRvIII in cellular responses to genotoxic stresses, such as ionizing radiation or other cytotoxic cancer therapeutic agents, have been only minimally investigated.

We have recently demonstrated that ionizing radiation in the therapeutic dose range of 1 to 5 Gy leads to 2- to 5-fold increases of EGFR Tyr phosphorylation resulting in radiation-induced activation of the receptor. This stimulation of EGFR mediates, through the activation of the MAPK and PI3K pathways, a major cytoprotective response $(8,27-30)$ that confers to cells enhanced radioresistance due to accelerated cell proliferation (7), an anti-apoptotic response (6), and improved repair functions after radiation exposures $(15,16)$. Both of these responses represent likely underlying mechanisms that modulate the radiosensitivity of human tumor cells in vitro and in vivo upon single and repeated radiation exposures $(14,15,30)$.

In the current study we have extended our investigation of EGFR wild-type (wt) function on cellular radiation responses to the potentially modulating effects by EGFRvIII. Because EGFRvIII is not expressed in cultured cells, these mechanistic studies were performed in vitro in $\mathrm{CHO}$ cells transfected with EGFRwt and/or EGFRvIII expression plasmids using conditions that yielded similar expression levels for both receptors. In these cells the effects of EGFRvIII expression on acute cellular radiation responses were examined including the modulation of cell survival and apoptosis in vitro. The studies yielded two novel findings expanding our understanding of EGFR responses to radiation and the interactions between EGFRvIII and other ERBB receptor Tyr kinases. Based on these results, EGFRvIII furnishes a stronger cytoprotective radiation response 
than EGFRwt, which is likely to the greater activation of EGFRvIII after irradiation. This activation is also transmitted into more potent stimulation of MAPK and AKT, thus identifying EGFRvIII as a critical component in the ERBB signaling circuitry and in cellular radiation responses.

\section{IV.1.2. Materials and methods}

\section{IV.1.2.1. Reagents and cell lines}

Unless specified otherwise, all reagents were from Sigma Chemical Co. (St. Louis, MO). All electrophoresis reagents were from BioRad (Hercules, CA); the EGFR tyrosine kinase inhibitor tyrphostin AG1478 was from Calbiochem (San Diego, CA); EGF was purchased from Sigma Chemical Co. (St. Louis, MO). Media and antibiotics were from GIBCO-BRL (Rockville, MD), and fetal bovine serum (FBS) was from Intergen (Purchase, NY). The following immunological reagents were used: the immunoprecipitating anti-EGFR monoclonal antibody (mAb) from Transduction Laboratories (Lexington, KY), the anti-Tyr phosphorylation mAb, Ab2, from Oncogene Science (Cambridge, MA), the anti-EGFR mAb for Western blotting, Abl4, from Neomarkers (Fremont, CA), and anti-EGFRvIII mAb, DH8.3 from Abcam (Cambridge, UK). The secondary $\mathrm{Ab}$, an anti-mouse alkaline phosphatase conjugate, was from Promega (Madison, WI). Other reagents included Protein G Plus/ Protein A Agarose from Oncogene Science (Cambridge, $\mathrm{MA}$ ), mAb to p42/44 MAPK (ERK2), C-14, and to AKT (sc-1619) both as agarose conjugates from Santa Cruz (Santa Cruz, CA). Myelin basic protein (MBP) as substrate for MAPK (Sigma Chemical Co., St. Louis, MO) or AKT (Santa Cruz, Santz Cruz, CA) was used as stocks of $10 \mathrm{mg} / \mathrm{ml}$ and $5 \mathrm{mg} / \mathrm{ml}$ in $\mathrm{H}_{2} \mathrm{O}$, respectively. The pCL6 plasmid was used as an empty vector control. The EGFRwt cDNA was kindly provided by A. Ullrich (Max-Planck-Institute for Biochemistry, Martinsried, Germany), and the phßAc.EGFRvIII expression plasmid was obtained from D. Bigner (Dept. of Pathology, Duke University, Durham, NC) (2).

The Chinese hamster ovary cell line, $\mathrm{CHO}$, and the A431 squamous carcinoma cell line were obtained from the American Type Tissue Collection (ATTC; Rockville, MD). All cells were maintained at $37^{\circ} \mathrm{C}$ in $95 \%$ air $/ 5 \% \mathrm{CO}_{2}$, except for irradiation, which was performed at $20^{\circ} \mathrm{C}$ in air. The $\mathrm{CHO}$ and the A431 cell lines were maintained in RPMI1640 medium containing 5\% FBS (RPMI/5FBS) and antibiotics (penicillin/streptomycin). Only mycoplasma-free cultures were employed as assured by monthly testing.

\section{IV.1.2.2. Transient transfection of $\mathrm{CHO}$ cells}


CHO cells were routinely seeded at $1.5 \times 105$ cells per $60-\mathrm{mm}$ dish. Cells were cultured for a total of 5 days in RPMI/5FBS. On day 3, transient transfections were performed. The conditions for optimal transfection efficiency were determined by Western analysis of EGFRvIII and EGFRwt protein expression levels $48 \mathrm{~h}$ after transfecting the $\mathrm{CHO}$ cells with varying amounts of the expression plasmids. In parallel transfection experiments with identical amounts of a pK7.GFP (green fluorescence protein) plasmid, provided by 1. Macarra (University of Virginia, Charlottesville, VA) were performed for microscopic quantification of transfection efficiency of GFP positive cells after $48 \mathrm{~h}$. Optimal conditions yielding $>90 \%$ transfection efficiencies were established with $0.5 \mu \mathrm{g}$ of the phßAc.EGFRvIII or pCMV.EGFRwt expression plasmid and $1.5 \mu \mathrm{g}$ of the empty vector using Lipofectamine PlusTM as a carrier (GIBCO-BRL, Gaithersberg, MD). For mock transfections, referred to as CHO.mock, $2 \mu \mathrm{g}$ of the empty vector was transfected under identical conditions. For the development of CHO cells co-expressing EGFRvIII and EGFRwt, varying amounts of the pCMV.EGFRwt DNA were co-transfected with $0.3 \mu \mathrm{g}$ of the ph $\beta A c$.EGFRvIII DNA and varying amounts of the empty vector keeping the total amount of DNA at $2 \mu \mathrm{g}$.

\section{IV.1.2.3. Cell treatments and irradiation}

Cells treatments and irradiation experiments were performed on day $5,48 \mathrm{~h}$ after transfection. Pretreatment of cells was with $5 \mu \mathrm{M}$ AG 1478 for 30 min. EGF exposures of cells was at 10 or 100 $\mathrm{ng} / \mathrm{ml}$ for $5 \mathrm{~min}$ except for EGF treatment for AKT assays, which was for $15 \mathrm{~min}$. For all irradiation experiments, cells were exposed to single doses of ionizing radiation at a dose rate of $1.8 \mathrm{~Gy} / \mathrm{min}$ using a ${ }^{60} \mathrm{Co}$ source. In time course experiments, cells were irradiated and incubated at $37^{\circ} \mathrm{C}$ for the times specified. Thereafter, media was removed and cells were washed once in ice-cold PBS, rapidly frozen on dry ice and stored at $-80^{\circ} \mathrm{C}$ until further processing.

\section{IV.1.2.4. Immunoprecipitations and western blot analysis}

Immunoprecipitation and Western blotting experiments were performed as previously described $(7,26,29)$. Briefly, frozen cells were lysed in ice-cold lysis buffer, and cell lysis was facilitated by repeated passage through a 20 -gauge needle. The protein levels in supernatants obtained after centrifugation (16,000 RPM, microcentrifuge) were quantified with a Bio-Rad protein assay kit (Bio-Rad Labs, Richmond, CA). Equal amounts of cellular protein were employed for Western blotting of EGFRwt, EGFRvIII and Tyr phosphorylation or for immunoprecipitations using antiEGFR mAb at $4^{\circ} \mathrm{C}$ for $90 \mathrm{~min}$ followed by incubation with Protein G Plus/ Protein A Agarose for 45 min. Immunoprecipitates were washed once in lysis buffer and twice in PBS. After size fractionation in 6\% SDS-polyacrylamide gels, proteins were transferred electrophorectically onto 
nitrocellulose membranes (BioRad, Hercules, CA). The membranes were then incubated with primary $\mathrm{mAb}$ followed by incubation with peroxidase-conjugated secondary mAb. For visualization, bands were developed with the CDP-Star kit (Tropix, Inc., Bedford, MA). For analysis of Tyr phosphorylation levels autoradiograms were quantified using Sigma Scan software (Jandel Scientific, San Rafael, CA) (30).

\section{IV.1.2.5. Immune complex kinase assays}

Identical protein aliquots from cell lysates were incubated with anti-ERK2 or anti-AKT mAbs at $4^{\circ} \mathrm{C}$ for $3 \mathrm{~h}$ or overnight, respectively. After washing once with lysis buffer and twice with $1 \mathrm{x}$ kinase buffer, $25 \mathrm{mM} \beta$-glycerophosphate, $\mathrm{pH} 7.4,15 \mathrm{mM} \mathrm{MgCl}_{2}$, immunoprecipitates were suspended in $40 \mu \mathrm{H}_{2} \mathrm{O}$ containing the appropriate substrates, consisting of $20 \mu \mathrm{g}$ MBP for MAPK or $1 \mu \mathrm{g}$ AKT substrate for AKT. The kinase reaction was initiated by addition of $10 \mu \mathrm{l}$ of $5 \mathrm{x}$ kinase buffer, $500 \mu \mathrm{M}$ ATP, and $\left[{ }^{32} \mathrm{P}\right]-\gamma-\mathrm{ATP}(5000 \mathrm{cpm} / \mathrm{pmol})(\mathrm{ICN}$ Biomedicals, Irvine, CA) and maintained at $37^{\circ} \mathrm{C}$ for $30 \mathrm{~min}$. Aliqouts of the assay mixture were placed on P81 paper and nonspecific binding of $\left[{ }^{32} \mathrm{P}\right]-\gamma$-ATP was removed by extensive washing in $180 \mathrm{mM}$ phosphoric acid. Incorporation of ${ }^{32} \mathrm{P}$ into bound $\mathrm{MBP}$ or $\mathrm{AKT}$ substrate was quantified by absorption to $\mathrm{P} 81$ followed by liquid scintillation spectroscopy (Beckman Instruments Inc., Schaumburg, IL) (27).

\section{IV.1.2.6. Colony formation assay}

Irradiation of cells was $48 \mathrm{~h}$ after transfection at doses of 2, 4 and $8 \mathrm{~Gy}$. Cells were incubated for an additional $24 \mathrm{~h}$, harvested and plated for clonogenic survival. The number of cells was adjusted to generate 50 - 300 colonies per dish at each radiation dose and plated into $60-\mathrm{mm}$ culture dishes. Cells were maintained at $37^{\circ} \mathrm{C}$ with $5 \% \mathrm{CO}_{2}$ for 12 days, stained with crystal violet, and colonies containing $\geq 50$ cells were counted to determine surviving fractions $(15,16)$.

\section{IV.1.2.7. Measurement of apoptosis}

Apoptosis rates were determined $24 \mathrm{~h}$ following exposure to $4 \mathrm{~Gy}$. The culture medium and trypsinized cells were centrifuged and resuspended in methanol:acetic acid (3:1). The cells were then washed twice more in methanol: acetic acid, pipetted onto microscopic slides and allowed to air dry. Following Giemsa staining, averages of 1500 cells were counted per slide to determine the percent of apoptosis.

\section{IV.1.2.8. Statistical analysis}

The effects of various treatments were compared using Student's $t$ test. Statistical comparisons between clonogenic survival curves were carried out by use of the $F$ test. The radiation DERs for 
mock control cells compared to conditions of EGFRvIII or EGFRwt expression were derived from the ratios of the dose for a survival of $37 \%\left(D_{37}\right)$ for the survival curves for EGFRvIII or EGFRwt corresponding cells and the mock control survival curves in single-dose clonogenic survival assays. Differences yielding a P-value of $<0.05$ were considered statistically significant. All values and means shown are $\pm \mathrm{SD}$, unless otherwise specified.

\section{IV.1.3. Results}

IV.1.3.1. EGFRvIII is unresponsive to EGF but is inhibited by AG1478 
The experiments in this section were designed to define the level of EGFRvIII ligand independence (20) and the constitutive activity of the receptor for radiation response studies in consecutive sections. These studies were performed with $\mathrm{CHO}$ cells that were co-transfected with

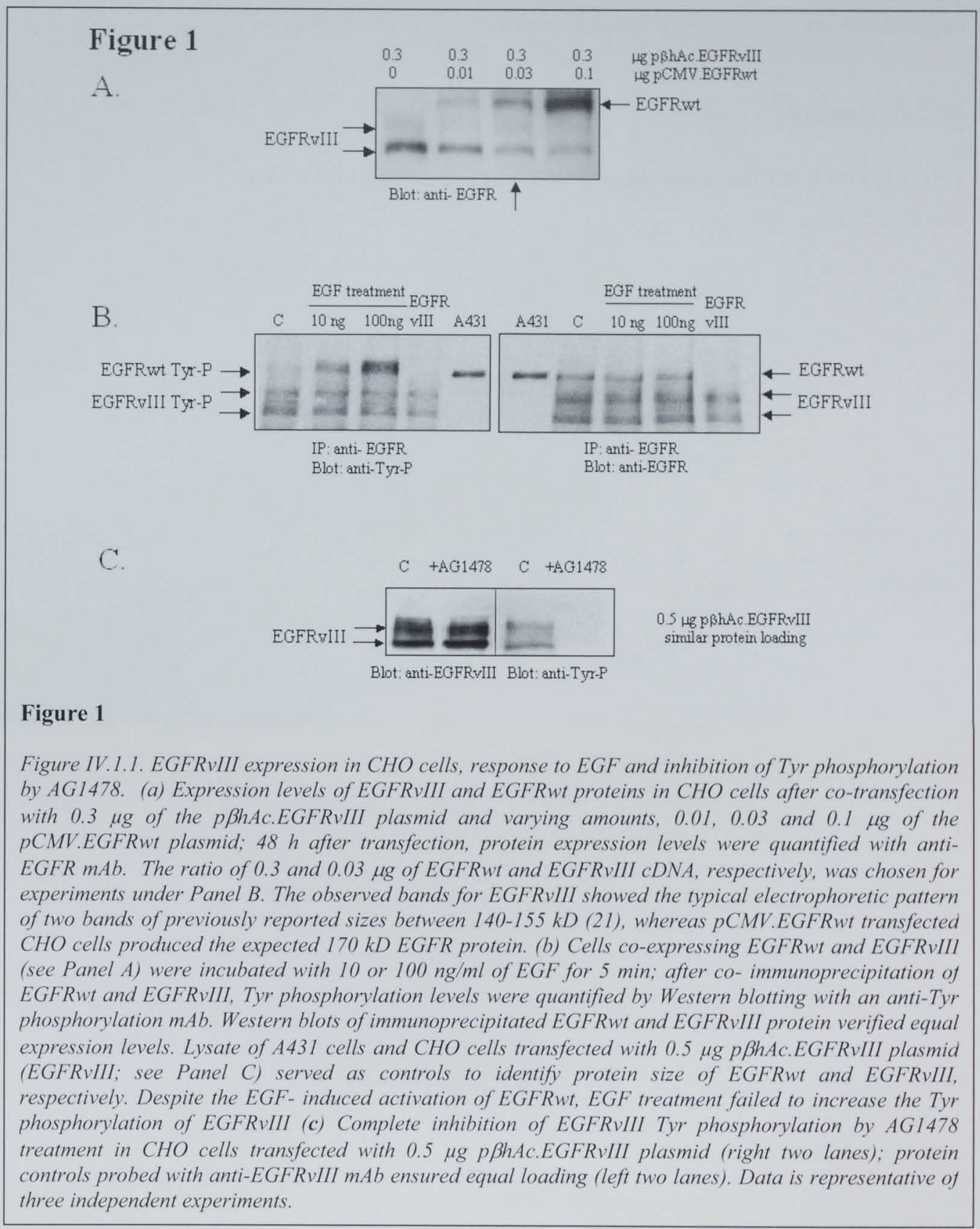


pßhAc.EGFRvIII and pCMV.EGFRwt to achieve similar protein levels, and the Tyr phosphorylation levels of EGFRwt and EGFRvIII were quantified after treatment with EGF and/or AG1478 for inhibition of EGFR Tyr kinase activity. Western blot analyses with an anti-EGFR mAb showed similar expression levels under these conditions (Fig. 1a). Treatment of CHO cells, coexpressing EGFRwt and EGFRvIII, with concentrations of 10 and $100 \mathrm{ng}$ EGF resulted in expected

Figure 2

A.

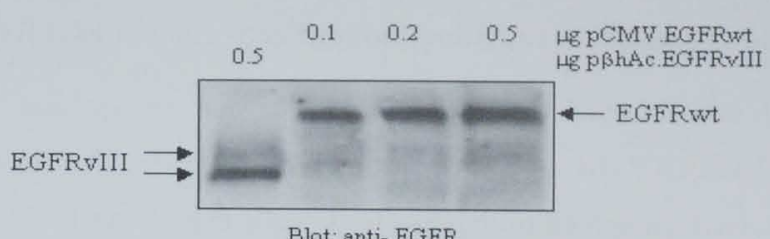

B.

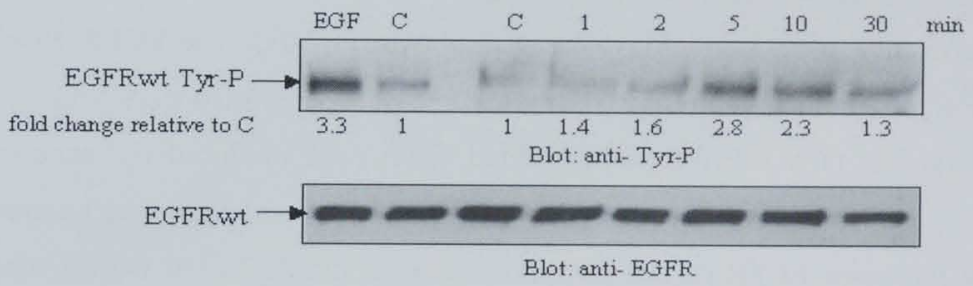

C.

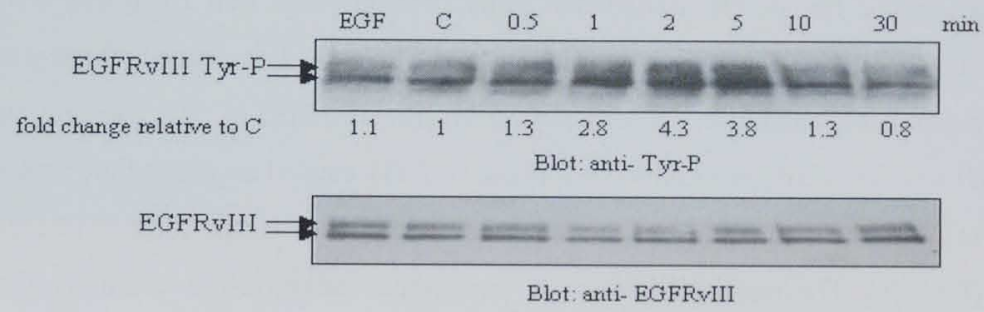

\section{Figure 2}

Figure IV.1.2. Radiation-induced stimulation of EGFRvIII Tyr phosphorylation in CHO cells. (a) Conditions of similar expression levels of EGFRwt and EGFRvIII in CHO cells after transient transfection with $0.5 \mu \mathrm{g}$ pCMV.EGFRwt or $0.5 \mu \mathrm{g}$ phAc.EGFRvIII were used throughout. These conditions were established by transfection with increasing amounts of pCMV.EGFRwt cDNA at 0.1, 0.2 and $0.5 \mu \mathrm{g}$. Protein expression was quantified $48 \mathrm{~h}$ after transfection by Western blotting (see Methods). (b) EGFRwt Tyr phosphorylation after treatment with EGF or radiation. CHO cells were transfected with $0.5 \mu \mathrm{g}$ pCMV.EGFRwt cDNA and, $48 \mathrm{~h}$ later, exposed to $10 \mathrm{ng} / \mathrm{ml}$ of EGF or 2 Gy of radiation (see Methods). Tyr phosphorylation levels of EGFRwt as a function of time after radiation were quantified by Western blotting (upper lanes) assuring identical protein loading (lower lanes). Lysate of A43I cells served as control for the protein size of EGFRwt. (c) EGFRvIII Tyr phosphorylation after treatment with EGF or radiation. CHO cells, transfected with $0.5 \mu \mathrm{g} \beta$ BhAc.EGFRvIII $c D N A$, were treated as described under Panel B. EGFRvIII Tyr phosphorylation was quantified for EGF after $5 \mathrm{~min}$ and for radiation between I and $30 \mathrm{~min}$ by Western blots (upper lanes) assuring identical protein loading (lower lanes). Data is representative of at least three independent experiments. 
dose-dependent increases in Tyr phosphorylation of EGFRwt. In contrast, the Tyr phosphorylation levels of EGFRvIII were only minimally affected (Fig. 1b, left panel). In examining further the functional consequences of EGFRvIII expression on signaling after irradiation of CHO.EGFRvIII cells, Western blot analyses of EGFRvIII Tyr phosphorylation confirmed its complete inhibition after AG1478 treatment (Fig. 1c). This data demonstrates the EGF-independence of EGFRvIII activity and its sensitivity to Tyr kinase inhibition by AG1478.

\section{IV.1.3.2. Ligand-independent radiation-induced activation of EGFRvIII}

The functional consequences of EGFRvIII expression on cellular radiation responses were examined in CHO.EGFRvIII cells, and the effects on downstream signal transduction pathways after irradiation were compared to those in CHO cells expressing EGFRwt alone (CHO.EGFRwt). Western blot analyses showed similar protein expression levels of EGFRvIII and EGFRwt $48 \mathrm{~h}$ after transfection using conditions described above (Fig. 2a). The EGFRvIII protein showed the typical electrophoretic pattern of two bands of previously reported sizes between 140-155 kD (Fig. 1; 22), whereas pCMV.EGFRwt transfected CHO cells produced the expected $170 \mathrm{kD}$ EGFR protein. As was previously shown for different carcinoma and malignant glioma cell lines $(15,28)$, radiation increased EGFRwt Tyr phosphorylation as did its ligand EGF. Quantification of these responses in the transiently transfected cells demonstrated that treatment with $10 \mathrm{ng} / \mathrm{ml}$ EGF induced a 3.3-fold $(\mathrm{P}<.001)$ increase in EGFRwt Tyr phosphorylation, which was similar to a 2.8fold increase after irradiation of cells with $2 \mathrm{~Gy}(\mathrm{P}=.0015)$ (Fig. 2b). Despite lacking response of EGFRvIII to EGF, a single radiation exposure of 2 Gy caused an immediate and maximum 4.3-fold activation of EGFRvIII $(\mathrm{P}=.001)$; this transient response returned to base-line phosphorylation by $30 \mathrm{~min}$ (Fig. 2c). The response patterns of immediate radiation-induced activation of EGFRvIII or EGFRwt were very similar in CHO.EGFRvIII or CHO.EGFRwt cells, respectively, but the incremental maximum activation was significantly greater for EGFRvIII when compared to EGFRwt ( $\mathrm{P}=.003$; Fig. 2b,c). Western blotting with an anti-EGFRvIII mAb revealed that both molecular weight species, the p140 and p155 protein, of EGFRvIII responded with similar increases in Tyr phosphorylation when compared to untreated controls (Fig. 2c).

\section{IV.1.3.3. Radiation-induced activation of EGFRvIII mediates enhanced MAPK activation}




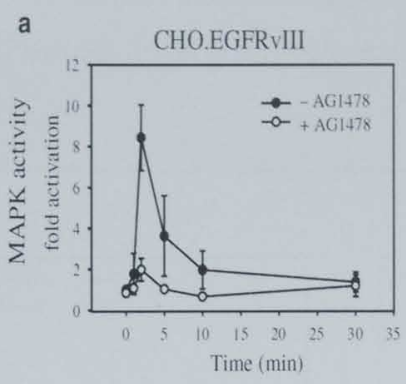

b

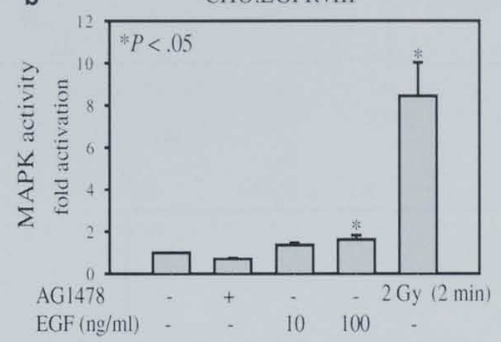

CHO.EGFRwt

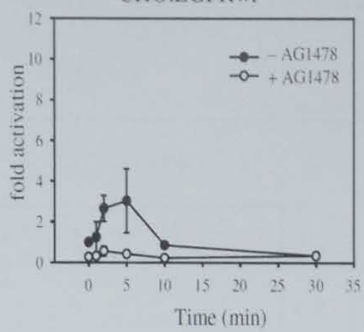

CHO.mock

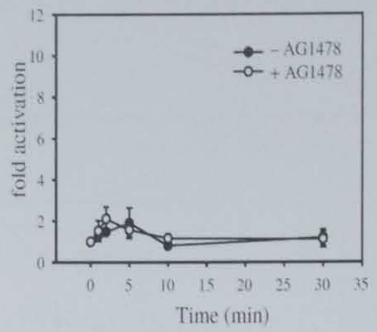

CHOEGFRwt

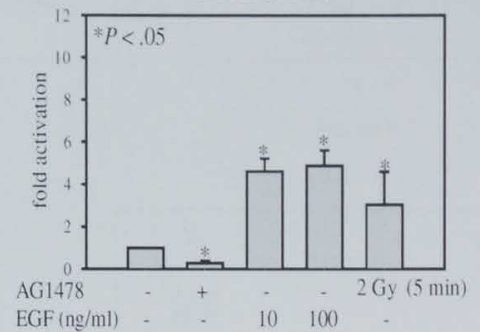

\section{Figure 3}

Figure IV.1.3. EGFRvIII- and EGFRwt-dependent activation of MAPK after exposure of transiently transfected CHO cells to EGF or radiation. (a) Radiation (2 Gy)-induced MAPK activation in CHO cells expressing EGFRvIII, EGFRwt or no EGFR protein. The effects of EGFRvIII or EGFRwt proteins were assessed through controls from cells pre-treated with AGI478 to completely eliminate receptor Tyr phosphorylation. Cells were transfected with $0.5 \mathrm{ug} c D N A$ each of p $\beta$ hAc.EGFRvIII (CHO.EGFRvIII), pCMV.EGFRwt (CHO.EGFRwt) or an empty vector (CHO.mock) as described in Material and Methods (see Figure 2a). Irradiation and MAPK activity time course experiments were initiated $48 \mathrm{~h}$ after transfection. For EGFR inhibition cells were pretreated with $5 \mu M$ AG1478 for 30 min. Activity is expressed as fold increase of ${ }^{32} \mathrm{P}$ incorporation relative to basal activity without treatment. Data is mean values $\pm S D$ of three independent experiments. Western blot analyses of representative cell samples transfected in parallel under identical conditions verified constant expression levels of the corresponding proteins and no EGFR expression in CHO.mock cells. (b) MAPK activity, normalized relative to basal levels without treatment in CHO.EGFRvIII or CHO.EGFRwt cells upon AG1478 treatment or EGF exposure at 10 or $100 \mathrm{ng} / \mathrm{ml}$, compared to the radiation response at $2 \mathrm{~Gy}$. Data for the fold activation of MAPK activity at 2 or 5 min after 2 Gy for CHO.EGFRvIII and CHO.EGFRwt, respectively were taken from Panel a. Data is presented as mean values $\pm S D$ of three independent experiments.

Having identified EGFRvIII as a target of radiation-induced activation, we next explored the ability of EGFRvIII to transmit radiation signals into the MAPK cascade and compared the findings with the radiation-induced MAPK activation that was identified as an important downstream target of EGFRwt in previous studies from our laboratory $(6,25,27)$. Using conditions similar to those described for experiments shown in Figure 2, CHO cells were transfected with pßhAc.EGFRvIII or 
pCMV.EGFRwt or subjected to mock (CHO.mock) transfection and irradiated $48 \mathrm{~h}$ later. Western blot analyses, as shown in Figure 2a, confirmed similar expression levels of EGFRvIII and

a

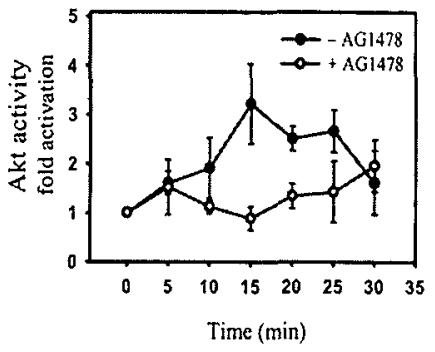

b

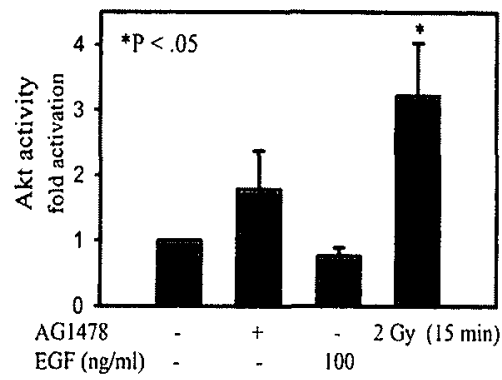

CHO.EGFRwt

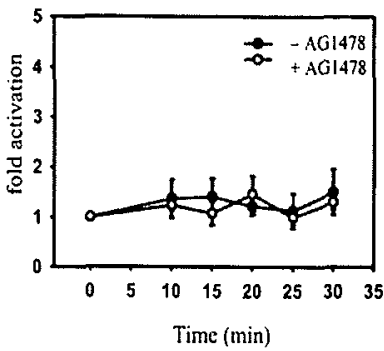

CHO.mock

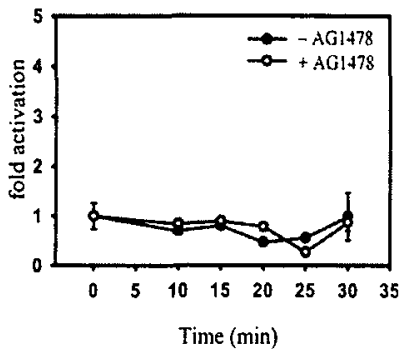

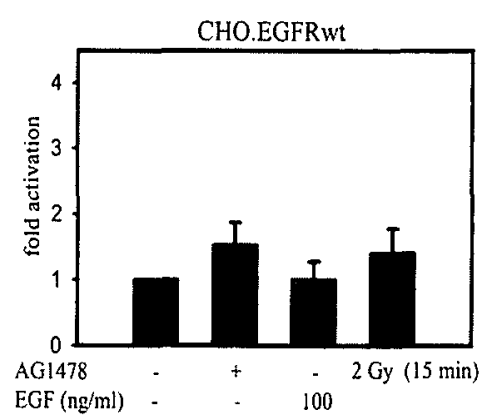

\section{Figure 4}

Figure IV.1.4. EGFRvIII- and EGFRwt- dependent activation of AKT after exposure of transiently transfected CHO cells to EGF or radiation. (a) Radiation-induced ( $G y)$ AKT activation in $C H O$ cells expressing EGFRvIII, EGFRwt or no EGFR protein (see legend Figure 3). The effects of EGFRvIII or EGFRwt proteins were assessed through controls from cells pre-treated with AG1478 to completely eliminate receptor Tyr phosphorylation. Treatments were $48 \mathrm{~h}$ after transfection using conditions described under Figure 3. AKT activity is expressed as fold increase of ${ }^{32}$ P-phosphate incorporation relative to basal activity without exposure to radiation. Data is mean values $\pm S D$ of three independent experiments. Western blot analyses of representative cell samples transfected in parallel under identical conditions verified constant expression levels of the corresponding proteins and no EGFRvIII or EGFRwt expression in CHO.mock cells. (b) AKT activity, normalized relative to basal levels without treatment, in CHO.EGFRwt and CHO.EGFRvIII cells upon AG 1478 treatment or EGF exposure at $100 \mathrm{ng} / \mathrm{ml}$ for 15 min, compared to the radiation response at $2 \mathrm{~Gy}$. Data for the fold activation of $A K T$ at 15 min after $2 G y$ were taken from Panel a. Data is presented as mean values $\pm S D$ of three independent experiments.

EGFRwt. In cells expressing EGFRvIII we found that 2 Gy induced a transient maximum 8.5-fold $(\mathrm{P}=.009)$ activation of MAPK peaking at $2 \mathrm{~min}$ and returning to base-line levels within $30 \mathrm{~min}$ (Fig. 3a, left panel) thus paralleling the phosphorylation response of the receptor (Fig. 2c). Pre-treatment of cells with AG1478 reduced this response $>75 \%$ to a 2 -fold radiation-induced MAPK activation substantiating its dependence upon EGFRvIII function. By comparison, activation of EGFRwt after 
2 Gy mediated a significant maximum 3.5-fold ( $\mathrm{P}=.045)$ activation of MAPK within $5 \mathrm{~min}$ (Fig. 3a, middle panel), a response that was also blunted by AG1478. The modest 2-fold activation of MAPK in CHO.mock cells was interpreted as a background response by these cells as it was not affected by treatment with AG1478 (Fig. 3a, right panel) and, therefore, was likely independent of EGFRvIII or EGFRwt expression. The different responses of CHO.EGFRvIII and CHO-EGFRwt cells to EGF treatment were impressively corroborated by the MAPK analyses. In CHO.EGFRvIII cells, EGF induced a modest but significant, 1.4 to 1.6 fold $(\mathrm{P}=.02)$, activation of MAPK whereas CHO.EGFRwt cells yielded a 5-fold increase ( $\mathrm{P}=.004$; Fig. 3b). The radiation-induced activation of MAPK in CHO cells expressing EGFRvIII was greater than the EGF-induced activation of MAPK in cells expressing EGFRwt (Fig. 3b). This data demonstrates that EGFRvIII expression has a profound effect of cellular radiation responses leading to potent receptor activation and transmitting amplified signals along the MAPK pathway.

\section{IV.1.3.4. Radiation-induced activation of EGFRvIII is also transmitted through the AKT/PI3K pathway}

In other cell systems the PI3K signal transduction pathway has been identified as another important downstream target of EGFRvIII (18). We therefore investigated the ability of radiation to induce PI3K activation by studying the response of PKB/AKT proto-oncogene in CHO.EGFRvIII cells and compared the findings with radiation-induced AKT responses in CHO.EGFRwt cells. Radiation transiently activated AKT 3.2-fold ( $\mathrm{P}=.009)$ within 15 min (Fig. 4a, left panel). By comparison, activation of EGFRwt after 2 Gy mediated a maximum 1.4-fold ( $P=N S$ ) activation of AKT within 15 min (Fig. 4a, middle panel), a response that was essentially un-affected by AG1478. The complete inhibition of the radiation-induced activation of AKT in CHO.EGFRvIII cells by AG1478 strongly suggests that the response was initiated at the level of EGFRvIII, a conclusion that is further substantiated by the finding that $\mathrm{CHO}$.mock cells furnished no radiation-induced AKT activation (Fig. 4a, right panel). However, AG 1478 treatment of CHO.EGFRvIII cells resulted in a minimum up-regulation of basal AKT activity without any further stimulation by radiation (Fig. 4a, b). The radiation-induced activation of AKT in CHO cells expressing EGFRvIII was greater than the radiation-induced activation of AKT in cells expressing EGFRwt (Fig. 4b). This data shows that radiation-induced activation of EGFRvIII is at least in part transmitted through the PI3K/AKT pathway. 


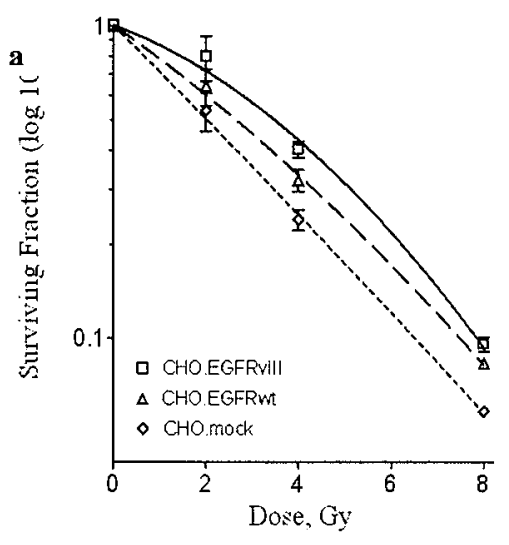

h

Single dose of $2 \mathrm{~Gy}$

Single dose of $4 \mathrm{~Gy}$
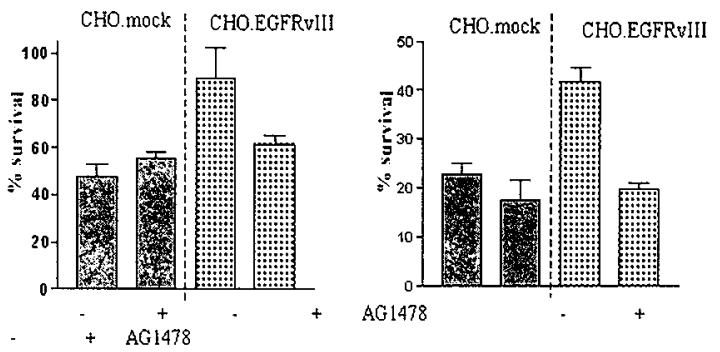

\section{Figure 5}

Figure IV.1.5. EGFRwt- and EGFRvIII- mediated modulation of radiosensitivity after exposure of transiently transfected $\mathrm{CHO}$ cells to varying single doses of ionizing radiation. (a) Clonogenic survival curves for CHO.EGFRwt, CHO.EGFRvIII or CHO.mock cells after radiation with single doses of 2,4 or 8 Gy. For experimental conditions see Methods. The surviving fraction after 12 days was determined from the number of colonies with $\geq 50$ cells relative to the number of cells plated after correction for plating efficiency. Data is provided as mean values \pm SD from a minimum of three experiments. (b) Conversion of the EGFRvIII- mediated modulation of radiosensitivity through treatment with AG1478. The effects of AG1478 treatment on the cellular radiosensitivity of CHO.mock and CHO.EGFRvIII were quantified by colony formation after irradiation of 2 and 4 Gy; pre-treatment of cells with AG1478 was as described under Methods. The surviving fraction was determined as described under Figure 5a. Data is provided as mean values $\pm S D$ from a minimum of three experiments.

\section{IV.1.3.5. Expression of EGFRvIII confers an enhanced cytoprotective response to ionizing radiation}

To correlate radiation-induced activation of EGFRvIII with the radiosensitivity of $\mathrm{CHO}$ cells, we examined cell survival after single radiation doses of 2, 4 and 8 Gy using colony formation assay and comparing cells expressing EGFRvIIl with cells expressing EGFRwt or mock-transfected cells. In addition, the contribution of EGFRvIII was examined through quantitative inhibition of EGFRvIII function using AG1478. As assessed by colony formation assays, CHO.EGFRvIII cells were less sensitive to varying single radiation exposures than CHO.EGFRwt or mock-transfected CHO cells ( $\mathrm{P}<0.001$; Fig. 5a) EGFRvIII mediated a significantly stronger cytoprotective response to radiation than EGFRwt $(\mathrm{P}<0.001)$, as reflected by a dose enhancment ratio (DER) of 1.61 relative to 1.32 for control relative to CHO.EGFRvIII or CHO.EGFRwt cells, respectively. 
As demonstrated in Figure 5b, expression of EGFRvIII conferred an almost 2-fold increase in clonogenic survival after exposure to $4 \mathrm{~Gy}$, indicating a doubling of radioresistance in this assay conferred by EGFRvIII expression compared to CHO.mock cells (Fig. 5b, right panel). AG1478 treatment almost completely eliminated this increase in radioresistance of CHO.EGFRvIII cells (Fig. 5b), again indicating that the cytoprotective response is initiated at the level of EGFRvIII.

\section{IV.1.3.6. Expression of EGFRvIII inhibits radiation- induced apoptosis}

Since the PKB/AKT proto-oncogene has been implicated in the regulation of apoptosis $(6,13)$, we further investigated the effects of EGFRvIII and EGFRwt expression on the radiation-induced

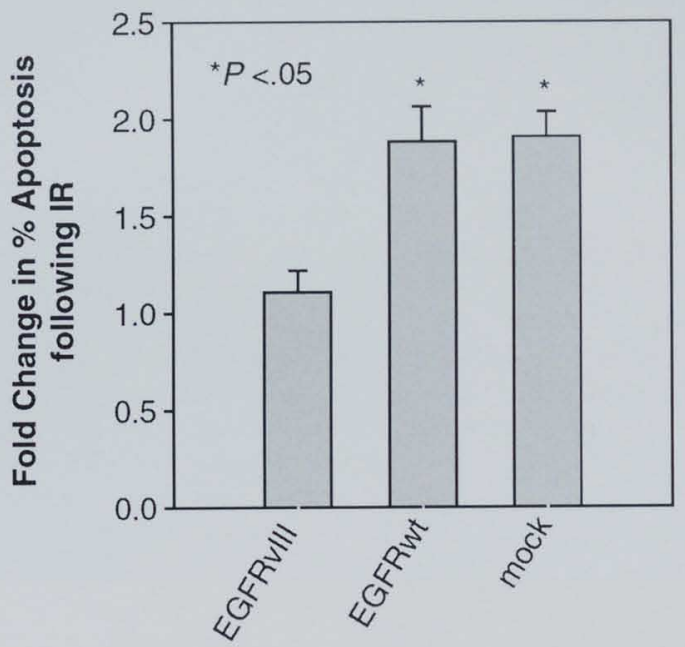

\section{Figure 6}

Figure IV.1.6. EGFRvIII-mediated modulation of radiation-induced apoptosis in CHO cells. Radiationinduced apoptosis in CHO.EGFRvIII, CHO.EGFRwt and CHO.mock cells after exposure of cells to 4 Gy. The cells were irradiated with a dose of $4 \mathrm{~Gy}$ and harvested 24 hours following irradiation. Radiation significantly increased apoptosis in CHO.EGFRwt and CHO.mock compared to CHO.EGFRvIII cells. Fold increase was calculated as fold increase in the percent apoptosis in irradiated compared to control cells. The results are the average of two independent experiments, provided as mean values $\pm S E M$.

apoptosis in $\mathrm{CHO}$ cells $24 \mathrm{~h}$ following ionizing radiation exposure. By comparison, irradiation of CHO.EGFRvIII cells with a single dose of 4 Gy induced only a minimal 1.1 -fold increase ( $\mathrm{P}=\mathrm{NS}$ ) in apoptosis relative to unirradiated controls. In contrast, exposure of both CHO.EGFRwt and CHO.mock cells to 4 Gy significantly enhanced apoptosis by an average of 1.9 -fold ( $\mathrm{P}=0.015$; Fig. 6). These results demonstrate that the presence of EGFRvIII, but not EGFRwt, counteracts 


\section{Chapter IV}

radiation-induced apoptosis in $\mathrm{CHO}$ cells, and suggest that the anti-apoptotic response is mediated through the radiation-induced EGFRvIII-dependent activation of AKT. 


\section{IV.1.4. Discussion}

The data presented in this study provides new insights into the biological functions of the constitutively active EGFRvIII. To date, mechanistic studies on this naturally occurring truncated receptor have been limited since its spontaneous expression is only seen in vivo in naturally occurring tumors or xenografts of human tumor cells (15) and is rapidly lost in vitro (3). In extension of previous studies on the role of EGFRvIII as an oncoprotein $(2,9,12,21,22)$, we have started to define its involvement in cellular responses to genotoxic stress, such as ionizing radiation. Our results define EGFRvIII as an important response molecule that is unresponsive to EGF (12) but is activated by radiation to a greater extent than EGFRwt. Since intensified responses of EGFRvIII are also transmitted as amplified signals at the level of MAPK (17) and AKT, EGFRvIII can be expected to mediate a more powerful cytoprotective response after irradiation than we have previously demonstrated for EGFRwt $(7,15,16,28)$. Since we have correlated these cytoprotective pro-survival responses of the EGFR/MAPK cascade with increased radioresistance the potential impact of EGFRVIII on cellular radiation responses is apparent.

Studies in CHO cells were performed because of the high transfection efficiencies (9), and the ability to control expression levels of both EGFRvIII and EGFRwt. The independent expression of both EGFR molecules was required to define their relative roles in generating activation responses, as quantified by receptor Tyr phosphorylation, after exposure of cells to growth factor ligands or ionizing radiation. While we have characterized the responses for EGFRwt in other cells it was important to quantify the potential contribution of the constitutively active EGFRvIII to cytoprotective responses in the same cell system. In addition to the controlled expression of EGFRwt and EGFRvIII, we also confirmed their effects on cellular signaling and survival responses using the EGFR-specific tyrphostin kinase inhibitor, AG1478 (11).

Irradiation of CHO cells, expressing similar levels of EGFRwt or EGFRvIlI, demonstrated independent activation of each receptor $(29,30)$. However, the 4.3-fold stimulation of EGFRvIII was consistently higher yielding a significant 1.8 -fold $(P=.03)$ greater activation relative to EGFRwt. The fundamental difference in response of the receptors was demonstrated upon exposure of cells to EGF that induced a 3.3-fold activation of EGFRwt but no significant enhancement in Tyr phosphorylation of EGFRvIII most likely due to deletions in the COOH-terminal EGF binding domain (31). A minor activation response through interaction with other ERBB receptors cannot be excluded $(5,23)$. The radiation response of EGFRvIII may be of considerable importance since we have demonstrated in previous studies that EGFR furnishes a significant cytoprotective response conferring cellular radioresistance that is mediated by radiation-induced proliferation and anti- 
apoptosis $(7)$, and by direct radiosensitization $(15,16)$ most likely due to transcription-controlled increased expression of repair proteins, including PCNA (Amorino et. al., unpublished results). In line with previous experiences, the relative importance of radiation-induced activation of both EGFRwt and EGFRvIII is adequately studied by exposure of cells to AG1478 since this treatment almost completely inhibited activation of different EGFR species and, therefore, can be expected to block downstream signaling $(11,29 ;$ Fig. 1).

The radiation-induced activation signals from EGFR are transmitted through the MAPK pathway $(7,16,26)$. This is affirmed by our finding that cells expressing EGFRvIII produced a minimum 2.5fold greater activation of MAPK than cells expressing EGFRwt (Fig. 3). The close functional link between EGFR Tyr phosphorylation and MAPK activation in transfected $\mathrm{CHO}$ cells was corroborated by the almost complete inhibition of MAPK by AG1478, confirming observations in NIH3T3 and U87MG cells that were transfected with EGFRvIII $(11,17,19)$. Since we have previously identified MAPK as a major downstream effector of the EGFR-mediated cytoprotective response after irradiation it can be expected that EGFRvIII expression in cells enhances this response relative to EGFRwt. These conclusions likely apply to PI3K, which demonstrates higher activity levels in EGFRvIII expressing cells (18) and acts in concert with MAPK in transmitting EGFRwt/EGFRvIII signals after irradiation to enhance anti-apoptotic responses. Detailed studies on the role of PI3K and its indirect dependence upon radiation-induced EGFR activation confirm its importance in cellular radiation responses (6).

While activation of MAPK and PI3K could predict the decreased radiosensitivity of cells, the contribution of EGFRvIII or EGFRwt to cellular radioresistance was more directly quantified by clonogenic survival of CHO.EGFRvIII and CHO.EGFRwt cells. The expression of EGFRvIII raised the surviving fraction in a radiation dose-dependent manner, demonstrating that $\mathrm{CHO}$ cells expressing EGFRVIII were significantly more resistant than their counterparts transfected under identical conditions with EGFRwt or control plasmids ( $\mathrm{P}<0.001)$. After 2 Gy the surviving fraction increased from approximately $50 \%$ to $85 \%$ (1.7-fold), an effect completely reversed upon inhibition of the receptor by AG1478. This difference changed to a 2.5-fold increase in relative radioresistance of EGFRvIII expressing cells after $4 \mathrm{~Gy}$. This data represents the most direct demonstration that radiation-induced activation of EGFR species and the secondary stimulation of the MAPK/PI3K/AKT cascades provides a strong cytoprotective signal with increased radioresistance through enhanced proliferation and repair $(7,15,26)$. From studies on p185neu (ERBB2), the impact of ERBB receptors on cellular radiosensitivity may not be limited to EGFR and its mutants (23-25) but likely depend upon the entire ERBB expression profile of a given tumor cells $(4,6,15)$. 
In summary, this study demonstrates the importance of EGFRvIII, likely expressed in many human tumors in vivo, in tumor cell radiation responses. Possibly due to its state of constitutive activation, EGFRvIII produces a greater activation signal after irradiation of cells than previously described for EGFRwt. Therefore, EGFRvIII can be expected to also produce a more pronounced cytoprotective response mediated by amplified activation of downstream effectors such as MAPK and PI3K. These findings therefore imply that in some carcinoma and glioma cell types therapeutic strategies targeting EGFR need to assure activity against EGFRvIII in order to achieve most effective radiosensitization of human carcinoma and malignant gliomas. 


\section{IV.1.5. References}

1. Amorino GP, Hamilton VM, Valeric K, Dent P, Lammering G and Schmidt-Ullrich RK. (2002). Mol. Biol. Cell., 13, 2233-2244.

2. Batra SK, Castelino-Prabhu S, Wikstrand CJ, Zhu X, Humphrey PA, Friedman HS and Bigner DD. (1995). Cell Growth Differ., 6, 1251-1259.

3. Bigner SH, Humphrey PA, Wong AJ, Vogelstein B, Mark J, Friedman HS and Bigner DD. (1990). Cancer Res., 50, 8017-8022.

4. Bowers G, Reardon D, Hewitt T, Dent P, Mikkelsen RB, Valerie K, Lammering G, Amir C and Schmidt-Ullrich RK. (2001). Oncogene, 20, 1388-1397.

5. Chu CT, Everiss KD, Wikstrand CJ, Batra SK, Kung HJ and Bigner DD. (1997). Biochem. J., 324 (Part 3), 855-861.

6. Contessa JN, Hampton J, Lammering G, Mikkelsen RB, Dent P, Valerie K and Schmidt-Ullrich RK. (2002). Oncogene, 21, 4032-4041.

7. Contessa JN, Reardon DB, Todd D, Dent P, Mikkelsen RB, Valerie K, Bowers GDand SchmidtUllrich RK. (1999).Clin. Cancer Res., 5, 405-411.

8. Dent P, Reardon DB, Park JS, Bowers G, Logsdon C, Valerie K and Schmidt-Ullich R. (1999). Mol. Biol. Cell, 10,2493-2506.

9. Ekstrand AJ, Longo N, Hamid ML, Olson JJ, Liu L, Collins VP and James CD. (1994). Oncogene, 9, 2313-2320.

10. Frederick L, Wang XY, Eley G and James CD. (2000). Cancer Res., 60, 1383-1387.

11. Han Y, Caday CG, Nanda A, Cavenee WK and Huang HJ.(1996). Cancer Res., 56, 3859-3861.

12. Huang HS, Nagane M, Klingbeil CK, Lin H, Nishikawa R, Ji XD, Huang CM, Gill GN, Wiley HS and Cavenee WK.(1997). J. Biol. Chem., 272, 2927-2935.

13. Kennedy SG, Kandel ES, Cross TK and Hay N. (1999). Mol. Cell. Biol., 19, 5800-5810.

14. Lammering G, Hewit TH, Hawkins WT, Contessa JN, Reardon DB, Lin PS, Valerie K, Dent P, Mikkelsen RB and Schmidt-Ullrich RK. (2001a). J. Natl. Cancer Inst., 93,921-929.

15. Lammering G, Lin PS, Contessa JN, Hampton JL, Valerie K and Schmidt-Ullrich RK. (2001b). Int. J. Radiat. Oncol. Biol. Phys., 51, 775-784.

16. Lammering G, Valerie K, Lin PS, Mikkelsen RB, Contessa JN, Feden JP, Farnsworth J, Dent P and Schmidt-Ullrich RK. (2001c). Clin. Cancer Res., 7, 682-690.

17. Montgomery RB, Moscatello DK, Wong AJ, Cooper JA and Stahl WL. (1995). J. Biol. Chem., 270, 30562-30566.

18. Moscatello DK, Holgado-Madruga M, Emlet DR, Montgomery RB and Wong AJ. (1998). J. Biol. Chem., 273, 200-206.

19. Moscatello DK, Holgado-Madruga M, Godwin AK, Ramirez G, Gunn G, Zoltick PW, Biegel JA, Hayes RL and Wong A.J. (1995). Cancer Res., 55, 5536-5539.

20. Moscatello DK, Montgomery RB, Sundareshan P, McDanel H, Wong MY and Wong AJ. (1996). Oncogene, 13, 85-96.

21. Nagane M, Coufal F, Lin H, Bogler O, Cavenee WK and Huang HJ. (1996). Cancer Res., 56, 50795086.

22. Nishikawa R, Ji XD, Harmon RC, Lazar CS, Gill GN, Cavenee WK and Huang HJ. (1994). Proc. Natl. Acad. Sci. USA, 91, 7727-7731.

23. O'Rourke DM, Kao GD, Singh N, Park BW, Muschel RJ, Wu CJ and Greene MI. (1998a). Proc. Natl. Acad. Sci. USA, 95, 10842-10847.

24. O'Rourke DM, Nute EJ, Davis JG, Wu C, Lee A, Murali R, Zhang HT, Qian X, Kao CC and Greene MI. (1998b). Oncogene, 16, 1197-1207.

25. O'Rourke DM, Qian X, Zhang HT, Davis JG, Nute E, Meinkoth J and Greene MI. (1997). Proc. Natl. Acad. Sci. USA, 94, 3250-3255.

26. Reardon DB, Contessa JN, Mikkelsen RB, Valerie K, Amir C, Dent P and Schmidt-Ullrich RK. (1999). Oncogene, 18, 4756-4766.

27. Schmidt-Ullrich RK, Contessa JN, Dent P, Mikkelsen RB, Valerie K, Reardon DB, Bowers G and Lin PS. (1999). Radiat. Oncol. Invest., 7, 321-330.

28. Schmidt-Ullrich RK, Dent P, Grant S, Mikkelsen RB and Valerie K. (2000). Radiat. Res., 153, 245 257.

29. Schmidt-Ullrich RK, Mikkelsen RB, Dent P, Todd DG, Valerie K, Kavanagh BD, Contessa JN, Rorrer 
WK and Chen PB. (1997). Oncogene, 15, 1191-1197.

30. Schmidt-Ullrich RK, Valerie K, Fogleman PB and Walters J. (1996). Radiat. Res., 145, 81-85.

31. Wong AJ, Ruppert JM, Bigner SH, Grzeschik $\mathrm{CH}$, Humphrey PA, Bigner DS and Vogelstein $\mathrm{B}$. (1992). Proc. Natl. Acad. Sci. USA, 89, 2965-2969. 


\section{Chapter IV}

IV.2. Inhibition of the EGFRvIII mutant receptor by dominantnegative EGFR-CD533 enhances malignant glioma cell radiosensitivity

Published in: Clin. Cancer Res., 2004 (IF = 5.07)

Guido Lammering, Theodore H. Hewit, Kristoffer Valerie, William Hawkins, Peck-Sun Lin, Ross B. Mikkelsen, Rupert K. Schmidt-Ullrich 


\section{Summary}

Purpose: The commonly expressed variant epidermal growth factor receptor (EGFR), the type-III EGFR variant (EGFRvIII), functions as an oncoprotein promoting neoplastic transformation and tumorigenicity. The role of EGFRvIII in cellular responses to genotoxic stress, such as ionizing radiation, is only minimally defined. Thus, we have investigated EGFRvIII as a potential modulator of cellular radiation responses and explored the feasibility of adenovirus (Ad)-mediated expression of dominant-negative (DN) EGFR-CD533 as a gene therapeutic approach for inhibiting EGFRvIII function in vitro and in vivo.

Experimental Design and Results: EGFR-CD533 and EGFRvIII were expressed in vitro and in vivo in malignant U-373 MG glioma cells through transduction with an Ad vector, Ad-EGFRCD533 and Ad-EGFRvIII, respectively. In vivo studies defined the importance of EGFRvIII as a modulator of radiation responses, demonstrating a 2.6-fold activation of EGFRvIII in U-373 MG tumors. Concomitant expression of EGFR-CD533 inhibited the radiation-induced activation of EGFRvIII in vitro, and completely abolished the enhanced clonogenic survival conferred by EGFRvIII. The ability of EGFR-CD533 to inhibit EGFRvIII function was further confirmed in vivo through complete inhibition of EGFRvIII-mediated increased tumorigenicity and radiation-induced activation of EGFRvIII. Growth delay assays with U-373 MG xenograft tumors demonstrated that the expression of EGFR-CD533 significantly enhanced radiosensitivity of tumor cells under conditions of intrinsic and Ad-mediated EGFRvIII expression.

Conclusion: We conclude that EGFRvIII confers significant radioresistance to tumor cells through enhanced cytoprotective responses and have demonstrated that DN EGFR-CD533 effectively inhibits EGFRvIII function. This data affirms the broad potential of EGFR-CD533 to radiosensitize human malignant glioma cells. 


\section{IV.2.1. Introduction}

Growth factors and their receptors play a central role in regulating both developmental and neoplastic progresses. As part of neoplastic progression, over-expression of the EGFR ${ }^{3}$, one of the ERBB receptors extensively implicated in tumorigenesis, is associated with the expression of naturally occurring variant species (1-6). Of these variant forms, the EGFRvIII, is most commonly expressed in human tumors (3). EGFRvII is characterized by deletion of exons 2-7, involving cDNA nucleotides 275-1075. Thus, EGFRvIII lacks a major portion of the Cys-rich ligand-binding domain, near the $\mathrm{NH}_{2}$-terminus of the extracellular portion of the molecule (7). EGFRvIII is constitutively active and is not further activated by EGFR ligands (8). In contrast to the wellestablished functions of EGFRvIII as an oncoprotein $(6,8-11)$ its role in cellular responses to genotoxic stresses, such as ionizing radiation or other cytotoxic cancer therapeutic agents, has been only minimally investigated.

Ionizing radiation in the therapeutic dose range of $1-5$ Gy induces activation of the EGFRwt, and other ERBB receptors, that initiate a major cytoprotective response including stimulation of MAPK, $\mathrm{PI} 3 \mathrm{~K}$ and $\mathrm{AKT}$ and induce radiation dose-dependent proliferation and anti-apoptotic responses (1214). We have previously demonstrated that a genetic approach of over-expressing EGFR-CD533, a DN variant of EGFR lacking 533 amino acids of the cytoplasmic domain $(15,16)$, completely disrupts this cytoprotective signaling by EGFRwt and its downstream effectors $(17,18)$. After having defined that EGFR-CD533 inhibits the basal and radiation-induced EGFR activation, which was established in vitro and in vivo and was linked to radiosensitization (19), it was important to next also investigate whether expression of EGFR-CD533 could also modulate EGFRvIII activity, since EGFRvIII is commonly expressed in tumors and previous findings suggested the inability of EGFRvIII to interact with other ERBB receptors $(3,8)$.

Therefore, in the current study we have applied the Ad- mediated delivery of EGFR-CD533 to malignant glioma cells expressing constitutively active EGFRvIII as an experimental gene therapeutic approach. Recent studies indicate that EGFRvIII is prominently activated by radiation, but not growth factor (20), and is widely expressed in vivo when human tumor cells are propagated as xenograft tumors. For these reasons it was important to demonstrate that the inhibitory function of EGFR-CD533 also applied to the constitutively active EGFRvIII as we have previously demonstrated for EGFRwt. In malignant glioma xenograft tumors the consequences of endogenous EGFRvIII expression on acute tumor cell radiation responses were examined. These studies were extended to include functional modulation of EGFRvIII by concomitant expression of EGFRCD533 in tumor cells transduced by adenoviral vectors, Ad-EGFRvIII and Ad-EGFR-CD533. This 
system defined the effects of EGFR-CD533 and EGFRvIII at similar expression levels on radiosensitivity of U-373 MG cells in vitro and tumor xenografts.

We confirm that EGFRvIII is expressed in experimental U-373 MG xenograft tumors and that its expression is down-regulated upon maintenance of cells in vitro. The basal expression of EGFRvIII in U-373 MG cells is markedly enhanced upon transduction of cells with Ad-EGFRvIII; cells transduced in vitro demonstrate accelerated growth rates in vivo supporting the oncogenic activity of this receptor. Using an experimental gene therapy approach, in vivo delivery into U-373 MG xenograft tumors of Ad-EGFRvIII and Ad-EGFR-CD533 achieved high expression of either or both receptors. Importantly, the expression of DN EGFR-CD533 dominated EGFRvIII with and without the combined use of irradiation.

\section{IV.2.2, Materials and Methods}

\section{IV.2.2.1. Reagents and cell lines.}

Protease and phosphatase inhibitors and other chemical reagents were purchased from Sigma Chemical Co. (St.Louis, MO). All electrophoresis reagents were from BioRad (Hercules, CA). Media and antibiotics were from GIBCO-BRL (Rockville, MD), fetal bovine serum (FBS) was from Intergen (Purchase, NY), and the tetracycline-free FBS was from Clontech Laboratories (Palo Alto, CA). The following mAbs were used: the anti-EGFR mAb cocktail (Ab14), reacting with $\mathrm{NH}_{2}$-terminal domains of the EGFR protein, for Western blotting (Neo Markers; Fremont, CA), the anti-EGFRvIII mAb, reacting with the N-terminal truncation of EGFR, DH8.3 (AbCam Limited, Cambridge, UK), anti-EGFR mAb, Ab5, for immunoprecipitation, the anti-phospho-Tyr mAb, Ab2, and the secondary peroxidase-conjugated goat anti-mouse Ab (Oncogene Science, Cambridge, MA). Other reagents included Protein G Plus/ Protein A Agarose from Oncogene Science (Cambridge, MA). The cDNA of EGFR-CD533, lacking the COOH-terminal 533 amino acids (15, 16) and the phßAc.EGFRvIII expression plasmid were kindly provided by A. Ullrich (Max-PlanckInstitute for Biochemistry, Martinsried, Germany) and by D. Bigner (8), respectively. The following cell lines were obtained from American Type Tissue Collection (ATTC; Rockville, MD): U-373 MG malignant glioma and $\mathrm{CHO}$ cell lines. All cells were maintained at $37^{\circ} \mathrm{C}$ in $95 \%$ air $/ 5 \% \mathrm{CO}_{2}$. CHO cell lines were maintained in RPMI 1640 medium containing 5\% FBS (RPMI/5FBS) with antibiotics (penicillin/streptomycin), whereas U-373 MG cells were maintained in MEM- $\alpha / 10 F B S$ and antibiotics.

\section{IV.2.2.2. Mice and tumors.}


Athymic female NCr-nu/nu mice were obtained from the National Cancer Institute-Frederick Cancer Research Facility (Frederick, MD). Animals used in this study were maintained under specific pathogen-free conditions in facilities approved by the American Association for Accreditation of Laboratory Animal Care and in accordance with current regulations and standards of the U. S. Department of Agriculture, U.S. Department of Health and Human Services, and the National Institutes of Health. Solitary tumors were produced by subcutaneous inoculation of $10^{7} \mathrm{U}$ $373 \mathrm{MG}$ cells into the right hind leg of 4 to 5 week old mice. Tumor cell suspensions were prepared from cells grown as monolayers in vitro. Experiments were initiated when tumor sizes reached 8 $10 \mathrm{~mm}$ in diameter.

\section{IV.2.2.3. Transient Transfection of CHO cells.}

CHO cells were routinely seeded at $1.5 \times 10^{5}$ cells per $60-\mathrm{mm}$ dish. On day 3 , transient transfections were performed; as optimal transfection conditions, yielding $>80 \%$ efficiency (20), $0.5 \mu \mathrm{g}$ of the phßAc.EGFRvIII expression plasmid with $1.5 \mu \mathrm{g}$ of an empty vector DNA were established for CHO cells using Lipofectamine PlusTM (GIBCO-BRL, Gaithersberg, MD). Western blot analyses verified detectable expression of the phßAc.EGFRvIII plasmid $48 \mathrm{~h}$ after transfection. CHO cells transfected with phßAc.EGFRvIII, referred to as CHO.EGFRvIII, were used as positive controls for EGFRvIII in Western blot analyses.

\section{IV.2.2.4. Recombinant Adenoviruses and in vitro Transduction Conditions.}

Replication-incompetent Ad was produced as previously described and successfully employed to the Ad-EGFR-CD533 vector $(21,22)$. Ad-EGFRvIII was constructed by transferring a SapI-XbaI fragment, spanning the coding sequence of EGFRvIII, into pZeroTGCMV followed by recombination in bacteria $(21,23)$. The pSL 1180 -EGFRM was kindly provided by S. Batra (Dept. of Biochemistry and Molecular Biology, University of Nebraska Medical Center, Omaha, NE). An Ad expressing the bacterial lacZ reporter gene (Ad-LacZ) was used as control virus $(21,23)$. Briefly, Ad-LacZ, Ad-EGFRvIII and Ad-EGFR-CD533 were produced in 293 cells as described (21) and purified by double $\mathrm{CsCl}$-gradient centrifugation followed by dialysis against $13 \%$ glycerol in phosphate-buffered saline $(21,23)$. The Ad vectors were frozen in liquid nitrogen and stored at $70^{\circ} \mathrm{C}$ until further use. Titration by standard plaque assay produced typical titers of $2-4 \times 10^{11}$ plaque-forming units per $\mathrm{ml}(\mathrm{pfu} / \mathrm{ml})$.

Transduction of the U-373 MG cell line with Ad was carried out by diluting viral stocks with PBS, adding Ad preparations to cell monolayers and placing dishes on a rocker with gentle continuous agitation in a tissue culture incubator for $4 \mathrm{~h}$ at $37^{\circ} \mathrm{C}$ followed by media change. A MOI of 3 was 
found to be optimal, as previously described (24). Mock transductions were carried out under identical conditions as the Ad transduction except for the addition of Ad preparations.

\section{IV.2.2.5. Cell treatments and irradiation protocols.}

Cell treatments and irradiation experiments in vitro were performed on day $5,48 \mathrm{~h}$ after transduction. EGF exposure of cells was at $10 \mathrm{ng} / \mathrm{ml}$ for $5 \mathrm{~min}$. For all irradiation experiments, cells were exposed to single doses of ionizing radiation at a dose rate of $1.8 \mathrm{~Gy} / \mathrm{min}$ using a ${ }^{60} \mathrm{Co}$ source. In time course experiments, cells were irradiated and incubated at $37^{\circ} \mathrm{C}$ for the times specified. Thereafter, media was removed and cells were washed once in ice-cold PBS, rapidly frozen on dry ice and stored at $-80^{\circ} \mathrm{C}$ until further processing. U-373 MG tumors of the specified sizes were irradiated in vivo. For this, animals were fully anaesthetized, and irradiation was focused on the right posterior leg bearing the tumor. Controls included mock irradiation of tumors under identical conditions. For immunochemical verification of radiation-induced EGFRvIII activation, as assessed by the extent of EGFRvIII Tyr phosphorylation, tumors were exposed to a single radiation dose of $4 \mathrm{~Gy}$ and excised $10 \mathrm{~min}$ after irradiation or mock irradiation, frozen immediately in liquid nitrogen, and processed as described below.

\section{IV.2.2.6. Immunoprecipitation and Immunoblotting Assays.}

Lysis and immunoprecipitation of cells was performed according to methods standard in our laboratory $(17,18,25)$. For each experiment, equal amounts of protein were used for immunoprecipiation or Western blot analysis. EGFRwt, EGFRvIII and EGFR-CD533 analyses in tumor tissue were performed in extracts from tumors instantly frozen in liquid nitrogen after excision. Tumor tissue was pulverized in liquid nitrogen using a mortar and pestle (26) and immediately lysed in ice-cold lysis buffer, $25 \mathrm{mM} \beta$-glycerophosphate, $25 \mathrm{mM}$ Tris, $\mathrm{pH} 7.4,10 \%$ $(\mathrm{v} / \mathrm{v})$ glycerol, $1.5 \mathrm{mM}$ EGTA, $0.5 \mathrm{mM}$ EDTA, 1\% Triton X-100, $1 \mathrm{mM}$ sodium orthovanadate, 1 $\mathrm{mM}$ sodium pyrophosphate, $15 \mu \mathrm{g} / \mathrm{mL}$ aprotinin, $15 \mu \mathrm{g} / \mathrm{mL}$ leupeptin, $2 \mu \mathrm{M}$ benzamidine, 150 $\mu \mathrm{g} / \mathrm{mL}$ PMSF. The cell suspension was passed sequentially through 16 to 21 gauge needles to facilitate cell lysis. Cell debris was removed by centrifugation at $14,000 \times g$ at $4^{\circ} \mathrm{C}$ for $10 \mathrm{~min}$, and the supernatants were processed for immunoprecipitation or Western blot analysis for EGFRwt, EGFRvIII and EGFR-CD533 protein expression and for EGFR wt and EGFRvIII Tyr phosphorylation. After electrophoresis on $6 \%$ SDS-polyacrylamide gels, proteins were transferred electrophoretically onto nitrocellulose membranes (BioRad, Hercules, CA). For visualization, bands were developed with the CDP-Star kit (Tropix, Inc., Bedford, MA). Autoradiograms were quantified using Sigma Scan software (Jandel Scientific, San Rafael, CA). 


\section{IV.2.2.7. Colony formation assay.}

Forty-eight hours after transduction with $3 \mathrm{MOI}$ of Ad-LacZ or Ad-EGFRvIII, or the combination of Ad-LacZ plus Ad-EGFR-CD533 or Ad-EGFRvIII plus Ad-EGFR-CD533 at 3 MOI for each Ad vector, cells were harvested and 500 cells plated for each group into 4-well $60-\mathrm{mm}$ dishes for clonogenic survival. Cells were incubated under standard culture conditions for 14 days, stained with crystal violet, and colonies containing $\geq 50$ cells were counted to determine the plating efficiency $(24,27)$.

\section{IV.2.2.8. Tumorigenicity and tumor growth.}

Prior to subcutaneous inoculation, U-373 MG cells were transduced in vitro with $3 \mathrm{MOI}$ for each Ad vector with Ad-EGFRvIII, Ad-LacZ, Ad-EGFRvIII plus Ad-EGFR-CD533 or Ad-LacZ plus Ad-EGFR-CD533, suspended in $0.1 \mathrm{ml}$ of PBS, and $8 \times 10^{6}$ cells/mouse and site were injected into the right flanks of female nude mice. The growth of palpable tumors was measured with a caliper every 3 days, and tumor volumes were calculated using width (a) and length (b) measurements $\left(a^{2}\right.$ $\mathrm{b} / 2.5$, where $\mathrm{a}<\mathrm{b}$ ) (28). Only tumors with a width or length of $\geq 4 \mathrm{~mm}$ were defined as palpable tumors. The endpoint for tumor growth assay was prospectively applied as evidence for measurable tumor growth within 65 days with a minimum mean tumor volume of $0.3 \mathrm{~cm}^{3}$.

\section{IV.2.2.9. Tumor Growth Delay.}

For the production of $\mathrm{U} 373$ xenograft tumors, $10^{7}$ cells were inoculated in the right hind leg of mice approximately 23 days before Ad infusion. Tumors at an average size of 0.2 to $0.3 \mathrm{~cm}^{3}$ were infused with the respective Ad vector or a combination of two Ad vectors; the combinations included AdLacZ/Ad-EGFR-CD533, Ad-LacZ/Ad-EGFRvIII and Ad-EGFRvIII/ EGFR-CD533. A single 6track infusion was performed as previously described $(19,24)$ on day -3 using $1.2 \times 10^{9} \mathrm{pfu} / \mathrm{Ad}$ vector/tumor. Irradiation with $3 \mathrm{~Gy}$ fractions on three consecutive days, as described above, was initiated $72 \mathrm{~h}$ after Ad infusion on day 0. Control experiments in three mice confirmed that AdLacZ resulted in an average $70 \%(+/-5 \%)$ transduction rate in vivo within $72 \mathrm{~h}$. Tumor growth was measured with calipers as described above for the conditions studied (see also legends of Figure 5). The endpoint for tumor growth delay assays was applied as quadrupling of the initial tumor volume on day 0 .

\section{IV.2.2.10. Statistical Analyses.}

All data is presented as means \pm S.E., unless otherwise specified. Statistical comparisons were carried out with the Students t-test, except for statistical comparisons between tumor growth curves, 
which were carried out using the F-test with the SAS software package (version 8.0; SAS Institute, Inc., Cary, NC). P values $<0.05$ were considered to be statistically significant. 


\section{IV.2.3. Results}

\section{IV.2.3.1. Expression of EGFRvIII in malignant glioma cells and xenograft tumors.}

EGFRvIII, a common mutant form of EGFR, is expressed in a variety of human tumors including

\section{Figure 1}

A.
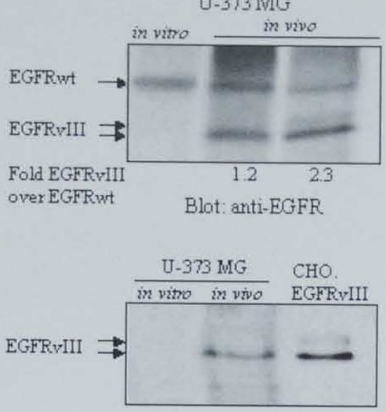

Blot: anti-EGFRviII

C.

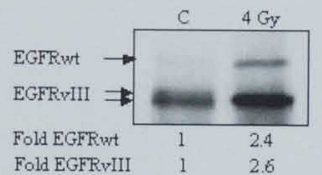

IP: anti-EGFR Blot: anti-Tyr-P
U.373 MG tumors

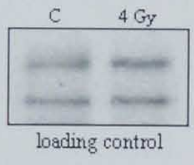

Blot: anti-EGFR

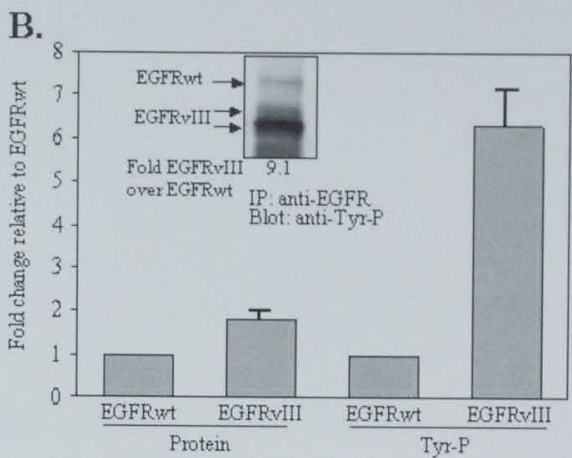

D.

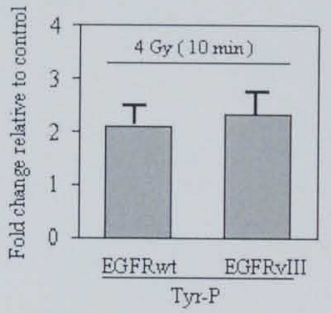

\section{Figure 1}

Figure IV.2.1. Expression, Tyr phosphorylation and radiation-induced activation of EGFRvIII in U-373 $M G$ cells and xenograft tumors derived thereof. A: EGFRvIII expression in U-373 MG tumors (in vivo) and the corresponding cells maintained in vitro (in vitro). CHO.EGFRvIII cell lysates were used as positive control (lower panel). Autoradiograms were quantified by densitometry, and EGFRvIII expression levels relative to EGFRwt are shown below each lane and expressed as fold difference (upper panel). B: Summary of results of the densitometry analyses of EGFRvIII expression and Tyr phosphorylation levels relative to EGFRwt in U-373 MG tumors. The autoradiogram shown of EGFRwt and EGFRVIII Tyr phosphorylation is representative of 4 tumors analyzed. EGFRvIII Tyr phosphorylation relative to that of EGFRwt is shown below and calculated as fold difference after correction for differences in protein expression. Bar graphs represent the fold difference of EGFRvIII protein expression and phospho-Tyr levels relative to EGFRwt in tumors. Error bars represent mean $\pm S D$. C: Radiationinduced activation of EGFRvIII in established U-373 MG xenograft tumors. Tyr phosphorylation levels of EGFRwt and EGFRvIII were detected in tumors 10 min after mock irradiation (control, C) or irradiation with a single exposure of $4 \mathrm{~Gy}$ and quantified by densitometry (left panel). Western blotting for EGFRwt and EGFRvIII protein verified equal loading (right panel; loading control). The data shown is representative of 3 independent experiments. D: Summary of the densitometry analyses of EGFRwt and EGFRvIII Tyr phosphorylation levels after 4 Gy to U-373 MG xenograft tumors. Results are shown as fold changes of EGFRwt and EGFRvIII Tyr phosphorylation relative to mock-irradiated tumors derived from 3 independent experiments. Error bars represent the mean $\pm S E$ 
carcinomas and malignant gliomas (29). In order to study the functional consequences of EGFRvIII expression on cellular radiation responses, we defined its expression in vivo and in vitro in our experimental systems. We first quantified the levels of EGFRvIII protein expressed in xenograft tumors of U-373 MG cells relative to cells maintained in vitro. EGFRvIII expression was quantified in extracts from freshly excised tumors, thus reflecting the expression levels in vivo.

As demonstrated in Figure $1 \mathrm{~A}$, upper panel, EGFRvIII was expressed at measurable levels in established U-373 MG tumors, but was undetectable in U-373 MG cells maintained in vitro. EGFRvIII protein expression was also not detected in cells that were isolated from EGFRvIII expressing tumors and then cultured in vitro (data not shown). Relative to EGFRwt, the EGFRvIII protein expression varied widely from 1.2 to 2.3-fold (Figure $1 \mathrm{~A}$, upper panel) as demonstrated by Western blotting using a mAb with broad reactivity to the EGFR protein. As described previously, EGFRvIII was identified as a $140 \mathrm{kDa} / 155 \mathrm{kDa}$ doublet band (6) with the lower size component typically expressed at higher levels. Similar results were obtained with an EGFRvIII-specific mAb confirming the absence of EGFRvIII in cultured cells and, again, demonstrating prominence of the $140 \mathrm{kDa}$ component in xenograft tumors. A similar $140 \mathrm{kDa}$ EGFRvIII protein band was seen on Western blots with extracts from CHO.EGFRvIII cells (Figure $1 \mathrm{~A}$, lower panel).

Having demonstrated the presence of EGFRvIII in human xenograft tumors, we next quantified the protein expression levels of EGFRvIII relative to EGFRwt in vivo and compared basal Tyr phosphorylation levels of both receptors after immunoprecipitation from tumor lysates before probing with anti-phospho-Tyr antibody on Western blots. As shown in Figure $1 \mathrm{~B}$, there was an average 1.8-fold higher expression of EGFRvIII relative to EGFRwt. Most likely reflecting the state of high constitutive activity of EGFRvIII, its Tyr phosphorylation in vivo was on average 6.3-fold higher $(\mathrm{P}<0.001)$ than that of EGFRwt (example inserted in Figure $1 \mathrm{~B}$ ). Similar results were obtained from MDA-MB-231 mammary carcinoma xenograft tumors (data not shown).

\section{IV.2.3.2. Ionizing radiation induces Tyr phosphorylation of EGFRvIII in vivo.}

We have previously demonstrated that ionizing radiation induced an immediate activation of EGFRwt in xenograft tumors, which showed a maximum activation within 10 min after a single 4 Gy radiation exposure (19). Thus, we investigated further the effects of ionizing radiation on EGFRvIII Tyr phosphorylation in vivo. To examine radiation-induced activation of EGFRvIII, established U-373 MG xenograft tumors were irradiated with $4 \mathrm{~Gy}$, harvested $10 \mathrm{~min}$ later, and processed for immunochemical analyses. We found that EGFRvIII and EGFRwt Tyr phosphorylation increased 2.6- and 2.4-fold, respectively, while protein levels of both receptors 
remained unchanged (Figure $1 \mathrm{C}$ ). Thus, averaging at least 3 experiments, ionizing radiation induced a significant overall 2.3-fold [range 1.5; 2.8] activation of EGFRvIII in U-373 MG tumors (Figure $1 \mathrm{D} ; \mathrm{P}<0.01$ ), a response similar to the average 2.1 -fold radiation-induced activation of EGFRwt. Considering the high constitutive activity of EGFRvIII (20), the mutant receptor, in addition to EGFRwt, is likely to represent an important modulator of radiation responses when tumor xenografts are irradiated.

\section{IV.2.3.3. Transduction of U-373 MG cells with EGFRvIII and EGFR-CD533 affect receptor} Tyr phosphorylation.

Our previous studies have shown, that expression of EGFR-CD533 reduced the basal and radiationstimulated Tyr phosphorylation of EGFRwt (19). In the present study, we examined whether expression of EGFR-CD533 could also modulate EGFRvIII activity. Because EGFRvIII was not expressed in cultured cells (Figure $1 \mathrm{~A}$ ), these studies were performed in U-373 MG cells in vitro transduced with Ad-EGFRvIII alone or in combination with Ad-EGFR-CD533. MOIs between 1 and 10 produced a dose-dependent increase in EGFRvIII expression (Figure $2 \mathrm{~A}$ ). Importantly, the expression of EGFRvIII was independent of the simultaneous expression of EGFR-CD533. The finding that a MOI of 3 produced similar expression levels of both mutant receptors demonstrate that there was no interference in the expression of the two receptors. In addition, within the time frame of the experiments, there was also no effect on the protein expression levels of EGFRwt (Figure 2 A, upper panel).

The functional status of the EGFRvIII and EGFR-CD533 mutant receptors in U-373 MG cells was studied next (Figure $2 \mathrm{~B}$ ) using conditions of equal protein expression (3 MOI) as demonstrated in Figure 2 A. EGFRwt and EGFRvIII phosphorylation levels were then determined after expression of EGFR-CD533. Relative to untreated controls, EGF treatment of U-373 MG cells induced a 2.2fold activation of EGFRwt. At the same time, EGFRvIII did not respond to EGF affirming that this receptor was not activated $(3,20)$. In contrast, the expression of EGFR-CD533 reduced the basal and EGF-induced Tyr-phosphorylation of EGFRvIII to $12 \%$ and $18 \%$ of the control conditions, respectively. This is in line with our previous observation that expression of EGFR-CD533 reduced EGFRwt Tyr phosphorylation by $>90 \%$ (see Figure $2 \mathrm{~B}$ ).

\section{IV.2.3.4. EGFR-CD533 counteracts the cytoprotective radiation response of EGFRvIII.}


To correlate radiation-induced activation of EGFRvIII with the radiosensitivity of U-373 MG cells, we examined cell survival after single radiation doses using colony formation assays and comparing

\section{Figure 2}

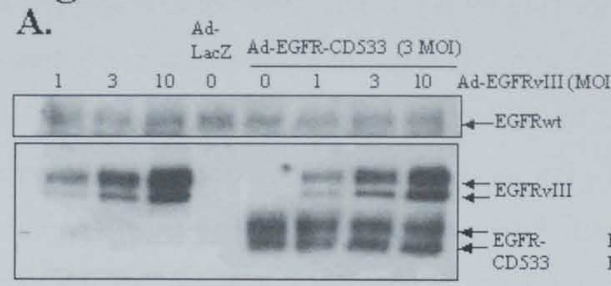

Blot: anti- EGFR

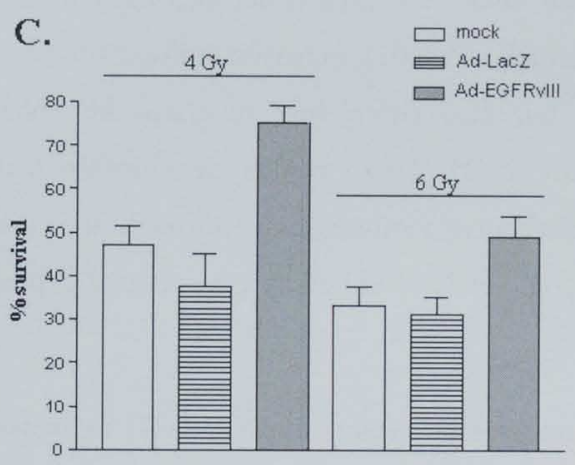

B.

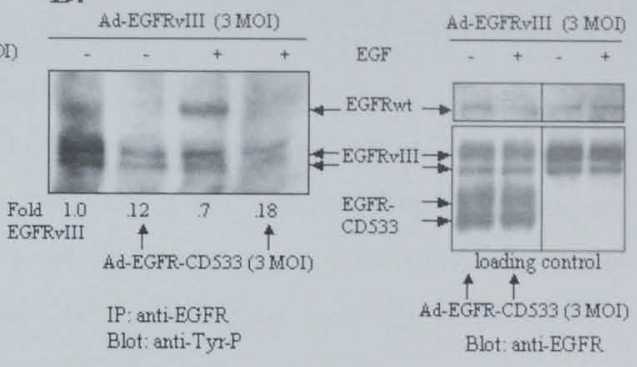

D.

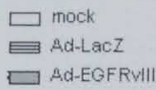

\section{Figure 2}

Figure IV.2.2. Adenovirus (Ad)- mediated expression of EGFRvIII and EGFR-CD533, effects of EGFRCD533 expression upon EGFRvIII activity, and radiosensitivity of U-373 MG cells. A: Ad-mediated expression of EGFRvIII with and without concomitant expression of EGFR-CD533. The Ad-EGFRvIIImediated, dose-dependent expression of EGFRvIII protein (varying multiplicities of infection (MOI); first 3 lanes) was unaffected by the simultaneous transduction of cells with Ad-EGFR-CD533 at a constant MOI (lanes 5 to 8); the same applied to the expression of EGFRwt (top panel; a longer exposure was required). B: Modulation of EGFRvIII Tyr phosphorylation by concomitant expression of EGFR-CD533. EGFRvIII Tyr phosphorylation was quantified after transduction with Ad-EGFRvIII alone or concomitant transduction with Ad-EGFR-CD533 (lanes labeled by arrows) and with or without additional EGF treatment. Western blotting for EGFRwt and EGFRvIII protein verified equal loading (right panel; loading control; a longer exposure was required for EGFRwt). EGFRvIII Tyr phosphorylation levels are shown below each lane expressed as fold difference relative to control (first lane). Data is representative of 3 independent experiments. C: Modulation of the radiosensitivity of U-373 MG cells expressing EGFRvIII. The radiosensitivity for the different transduced cell groups irradiated with 4 or 6 Gy was measured by colony formation assays. D: Radiosensitization of U-373 MG cells through EGFR-CD533 expression regardless of concomitant EGFRvIII expression. Cells were transduced, irradiated and assayed for clonogenic survival under conditions identical to those under Panel $C$ with concomitant Ad expression of EGFR-CD533. Data presented under Panel $C$ and $D$ is as mean values $\pm S D$ from 2 independent experiments performed in quadruplicate. 
cells expressing EGFRvIII with control (Ad-LacZ) or mock-transduced cells (Figure $2 \mathrm{C}$ ). As assessed by colony formation assays, U-373 MG cells transduced with Ad-EGFRvIII exhibited reduced radiosensitivity relative to cells subjected to Ad-LacZ- or mock-transduction, a finding consistent with our previously results linking EGFRvIII expression to an enhanced cytoprotective response (20) and increased relative radioresistance (Figure $2 \mathrm{C}$ ). The different average $47 \%$ and $33 \%$ reductions $(\mathrm{p}<0.01) \%$ in cell survival after 4 and $6 \mathrm{~Gy}$, respectively, suggest a radiation dose response. This response was minimally modified by infection of U-373 MG cells with Ad-LacZ (Figure $2 \mathrm{C}$ ), yielding survival rates of $38 \%$ and $31 \%$ for 4 and $6 \mathrm{~Gy}$, respectively. In contrast to control conditions, the transduction of cells through Ad-EGFRvIII yielded significantly $(\mathrm{p}<0.001)$ enhanced survival rates of $75 \%$ and $49 \%$ for 4 and $6 \mathrm{~Gy}$, respectively. The survival levels were also significantly different $(\mathrm{p}=0.019)$ for the two doses employed, again suggesting a cellular radiation dose response (Figure $2 \mathrm{C}$ ). In comparison, under all three conditions the concomitant transduction with Ad-EGFR-CD533 not only significantly $(\mathrm{P}<0.01)$ increased radiosensitivity of $\mathrm{U}$ 373 MG cells as previously described (17-19), but also completely reversed the enhanced clonogenic survival mediated by EGFRvIII (Figure $2 \mathrm{D}$ ). These results demonstrate that the radiation-induced activation of EGFRVIII conferred relative radioresistance through an enhanced cytoprotective response and that this response was completely inhibited by concomitant expression of EGFR-CD533 $(20,30)$.

\section{IV.2.3.5. EGFR-CD533 inhibits the enhanced tumorigenic effects of EGFRvIII expressed in xenograft tumors.}

The next set of experiments examined the effects of EGFRvIII expression on U-373 MG xenograft radiosensitivity in vivo. These experiments are important since the high constitutive activity of EGFRvIII is one likely reason for decreased radiosensitivity and enhanced tumorigenicity of malignant glioma cells (expressing this mutated receptor) (3). Hence, we extended our studies to EGFRvIII and EGFR-CD533 interactions in vivo and examined tumor growth as a function of EGFRvIII expression with and without the concomitant expression of EGFR-CD533. In the first set of experiments, the effects of enhanced EGFRvIII expression on xenograft tumor growth were examined relative to the $\mathrm{LacZ}$ control vector using cells that were grown in vivo after transduction in vitro (see Methods). 
In addition, we defined the relative effects of EGFRvIII and EGFR-CD533 on xenograft growth in U-373 MG cells (Figures $3 \mathrm{~A}$ and B). U-373 MG cells were transduced in vitro through infections with Ad-EGFRvIII or Ad-LacZ and with Ad-EGFRvIII plus Ad-EGFR-CD533 or Ad-LacZ plus Ad-EGFR-CD533; $48 \mathrm{~h}$ after infection, $8 \times 10^{6}$ transduced cells were inoculated into mice.

\section{Figure 3}

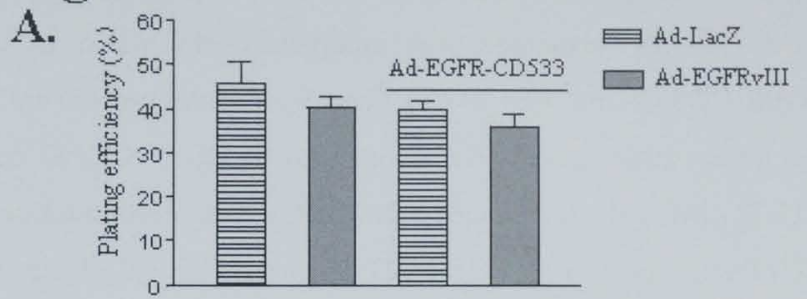

B.

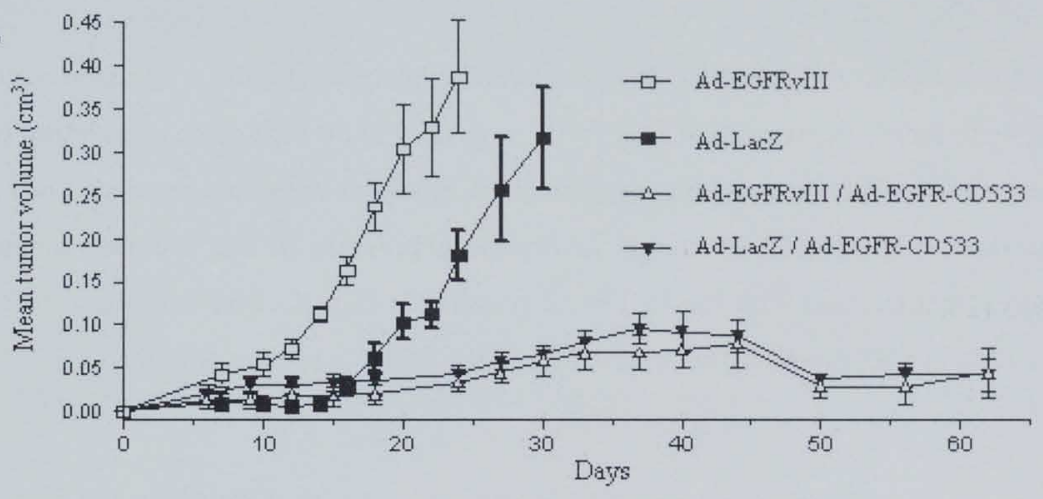

C.

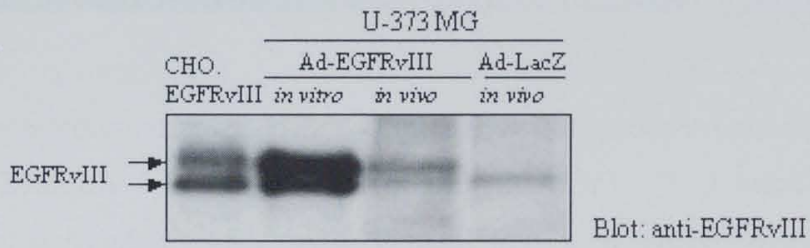

\section{Figure 3}

Figure IV.2.3. U-373 MG xenograft growth in nude mice of cells infected in vitro with Ad-EGFR-CD533 or Ad-EGFRvIII and a combination of the two relative to Ad-LacZ control. A: Colony formation efficiency of U-373 MG cells transduced in vitro with Ad-LacZ, Ad-EGFRvIII, Ad-LacZ plus Ad-EGFRCD533 or Ad-EGFRvIII plus Ad-EGFR-CD533 prior to inoculation. Transduced U-373 MG cells were plated for colony formation assays at the time that same batch of cells was inoculated into mude mice. B: Tumorigenic activity of U-373 MG cells expressing EGFRvIII compared to co-expression of EGFRvIII with EGFR-CD533. Error bars represent mean \pm SE for 5 animals per group.C: Western blot analyses of Ad-mediated expression of EGFRvIII in established U-373 MG xenograft tumors at the same time at which growth curves under B were terminated. U-373 MG cells transduced with Ad-EGFRvIII in vitro (in vitro lane) and lysate of CHO.EGFRvIII cells served as positive controls for EGFRvIII. 
Independent immunoblotting analyses for EGFRvIII and EGFR-CD533 verified similar Admediated expression of EGFRvIII with and without concomitant expression of EGFR-CD533, and EGFRwt expression remaining unchanged (Figure $2 \mathrm{~A}$ ). Colony formation assays for the four different cell groups, plated at the time of subcutaneous inoculation of cells, revealed plating efficiencies between 35 to $45 \%$, indicating only minor differences in cell viability (Figure $3 \mathrm{~A}$ ). U$373 \mathrm{MG}$ cells expressing EGFRvIII demonstrated significantly accelerated growth $(\mathrm{P}<0.001)$ generating tumors of $0.3 \mathrm{~cm}^{3}$ within 20 days compared to 30 days for U-373 MG cells transduced with Ad-LacZ (Figure $3 \mathrm{~B}$ ). This growth advantage was completely eliminated in cells concomitantly expressing both EGFR-CD533 and EGFRvIII; these U-373 MG cells did not generate tumors during the 65 days observation period. The expression of EGFR-CD533 had a similar growth inhibitory effect on U-373 MG cells transduced with Ad-LacZ suggesting inhibition of both endogenous EGFRwt and EGFRvIII receptors by EGFR-CD533 as the likely mechanism.

This conclusion was further supported by immunochemical analyses (Figure $3 \mathrm{C}$ ) demonstrating the qualitative and quantitative expression of EGFRvIII in vivo 24 to 30 days after inoculation of tumor cells transduced with EGFRvIII or LacZ, respectively. Consistent with data presented in Figure 1, the basal expression of EGFRvIII in tumors favors the expression of the $140 \mathrm{kDa}$ component of EGFRvIII whereas transfection with the EGFRvIII plasmid or transduction with the Ad-EGFRvIII viral vector resulted in a relatively higher expression of the $155 \mathrm{kDa}$ species (Figure $3 \mathrm{C}$ ).

\section{IV.2.3.6. Modulation of radiation-induced EGFRvIII activation by EGFR-CD533 in xenograft tumors.}

We next examined the functional consequences of EGFR-CD533 expression on radiation-induced EGFRvIII activation in established U-373 MG xenograft tumors infused with Ad-LacZ or AdEGFR-CD533 using our previously established techniques (19). The radiation-induced activation of both EGFRwt and EGFRvIII in U-373 MG xenograft tumors was inhibited $>90 \%$ when tumors were infused with Ad-EGFR-CD533 prior to irradiation; tumors infused with the Ad-LacZ control vector demonstrated radiation-induced Tyr phosphorylation levels similar to untreated tumors (Figure $4 \mathrm{~A}$, first two lanes; figure $1 \mathrm{C}$, left panel). As shown in Figure $4 \mathrm{~A}$ (lanes 3 and 4), EGFRwt and EGFRvIll protein expression was un-affected by infusion with Ad-EGFR-CD533 or Ad-LacZ. The protein expression data (Figure $4 \mathrm{~B}$ ) demonstrated similar relative expression levels of the EGFR-CD533 and EGFRwt in vitro and in tumors, and showed no change in basal protein expression of EGFRwt and EGFRvIII in tumors after infusion with Ad-EGFR-CD533 or Ad-LacZ (see Figure $5 \mathrm{~A}$ ). 


\section{Figure 4}

A.

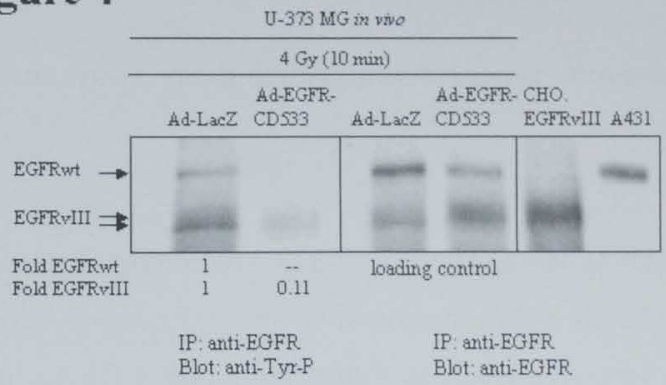

B.

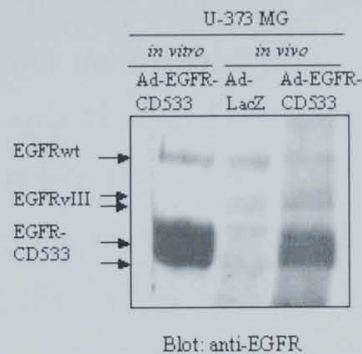

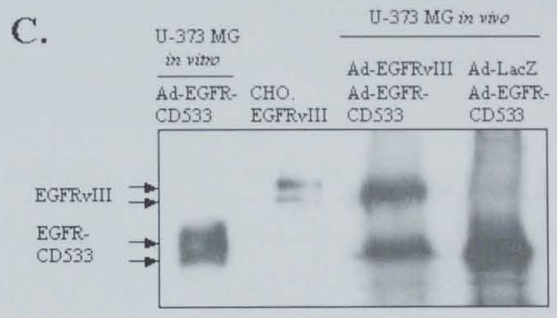

Blot: anti-EGFR

\section{Figure 4}

Figure IV.2.4. Functional consequences of EGFR-CD533 expression on radiation-induced activation of intrinsic EGFRvIII in U-373 MG tumor xenografts and expression levels of EGFRvIII and EGFR-CD533 in established tumors intratumorally infused with different combinations of Ad vectors. A: Decreases in EGFRvIII Tyr-phosphorylation in U-373 MG tumors intratumorally infused with Ad-EGFR-CD533 10 min after irradiation with 4 Gy. EGFRwt and EGFRvIII Tyr phosphorylation levels were quantified by immunoblotting (lanes 1 and 2) assuring identical protein loading (loading controls; lanes 3 and 4 lanes). EGFRwt and EGFRvIII Tyr phosphorylation levels are shown below and calculated as fold difference to LacZ. A431 and CHO.EGFRVIII cell lysates were used as positive controls. B: Western blot analyses of intrinsic EGFRvIII expression and Ad-mediated EGFR-CD533 expression in U-373 MG tumors (in vivo lanes). Established tumors were infused with either Ad-LacZ or Ad-EGFR-CD533 and 24 and 32 days later examined for EGFR expression, repectively. Lysates of cells transduced in vitro with Ad-EGFRCD533 were used as positive control. These protein expression data apply to in vivo conditions of tumor growth assays shown under Figure $5 \mathrm{~A}$. C: Western blot analyses of Ad-mediated concomitant expression of either EGFRvIII and EGFR-CD533 or LacZ and EGFR-CD533 in U-373 tumors (in vivo lanes). Established tumors were 3 days after intratumoral Ad infusion analyzed for EGFRvIII and EGFR-CD533 expression. Lysates of cells transduced in vitro with Ad-EGFR-CD533 and CHO.EGFRvIII cell lysates were used as positive controls. These protein expression data apply to in vivo conditions of tumor growth assays shown under Figure 5 B.

Figure $4 \mathrm{C}$ demonstrates, as controls, the expression patterns and levels for U-373 MG cells transduced with Ad-EGFR-CD533 and CHO cells transfected with the EGFRvIII plasmid. Combined intratumoral infusion of Ad-EGFRvIII and Ad-EGFR-CD533 resulted in similar receptor 
protein levels (Figure $4 \mathrm{C}$, lane 3), relative to those seen after infusion of Ad-EGFR-CD533 and Ad-LacZ, conditions under which the EGFR-CD533 expression levels far exceeded the basal expression levels of EGFRwt and EGFRvIII (Figures 4 B and C; also see Figure 5 B).

\section{IV.2.3.7. EGFR-CD533 radiosensitizes tumor xenografts in growth delay assays independent of EGFRvIII expression levels.}

The radiosensitizing effects of EGFR-CD533 were tested in U-373 MG xenograft tumors under conditions of basal EGFRvIII expression levels and over-expression after infusion of Ad-EGFRvIII into tumors (leading to high EGFRvIII expression levels as shown in Figures $4 \mathrm{C}$ ). Tumor growth delay assays, using $3 \times 3$ Gy radiation exposures and the different transduction conditions after intratumoral infusion of each Ad vector, were employed to quantify the relative effects of EGFRvIII and EGFR-CD533 on tumor radiosensitivity. Western blot analyses of extracts from infused U-373 MG tumors verified continued high expression levels of EGFR-CD533 even 32 days after Ad vector infusion (Figure $4 \mathrm{~B}$, lane 3); this affirmed the prolonged transgene expression after Ad transduction. The EGFR mutant protein expression levels resulting from intratumoral infusion with either Ad-EGFR-CD533 and Ad-EGFRvIII, or Ad-LacZ and Ad-EGFR-CD533 are shown in Figures $4 \mathrm{C}$. 
Figure 5 A.

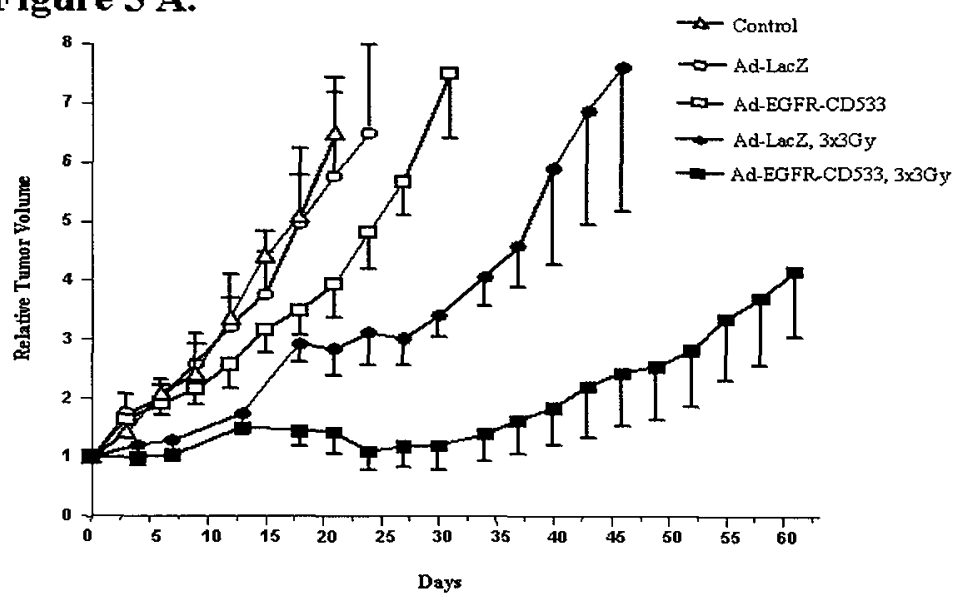

\begin{tabular}{|c|c|c|c|}
\hline Treatment: & Ad-EGFR-CDS33 & $3 \times 3$ Gy & Ad-EGFR-CDS33 + 3 33 Gy \\
\hline $\begin{array}{c}\text { Growth delay time (in days) } \\
\text { relative to Ad-Lac } Z \text { alone } \\
\text { (to reach rel. tumor vol. 4) }\end{array}$ & 5 & 18 & 44 \\
\hline
\end{tabular}

\section{Figure 5 B.}

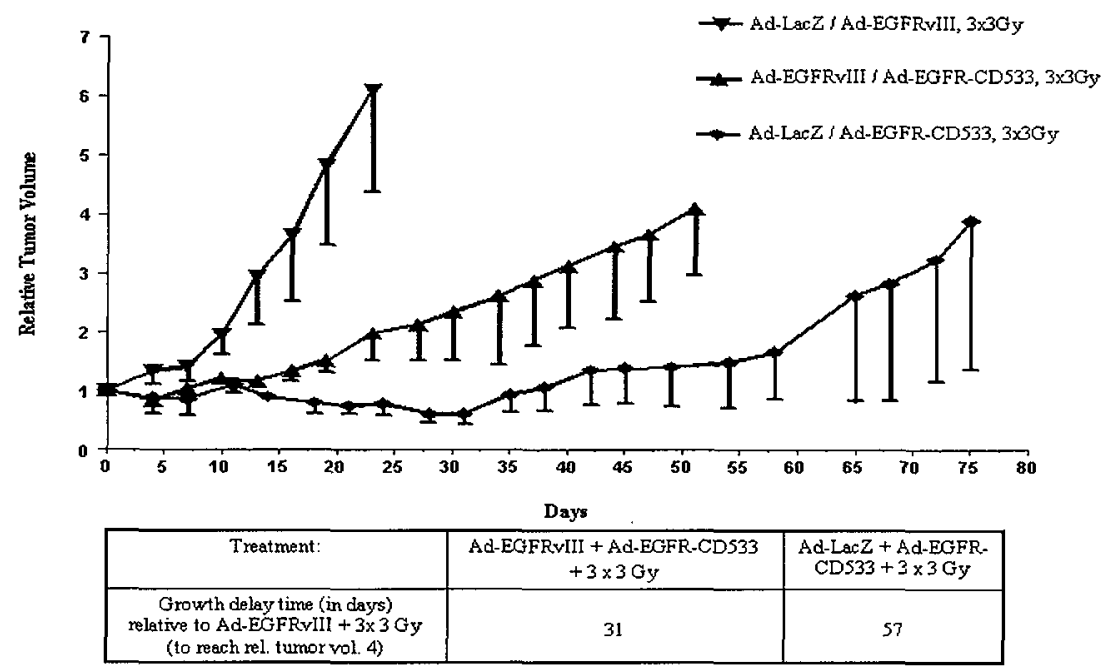

\section{Figure 5}

Figure IV.2.5. Effect of EGFR-CD533 expression on U-373 MG tumor xenograft radiosensitivity. A: Tumor growth delay assays of tumor xenograft alone (control) or after intratumoral infusion with either $A d$-LacZ or Ad-EGFR-CD533 and mock irradiation or repeated irradiation (3x3 Gy). Error bars represent the mean relative tumor volume $\pm S E$ for 4 to 6 animals per group. B: Tumor growth delay assays of U-373 MG tumor xenografts after intratumoral infusion with Ad-LacZ plus Ad-EGFR-CD533, Ad-EGFRvIII plus Ad-EGFR-CD533 or Ad-LacZ plus Ad-EGFR-CD533 and repeated irradiation ( $3 \times 3$ $G y)$. Error bars represent the mean relative tumor volume $\pm S E$ for a minimum of 4 animals per group. The tumor size on day 0 immediately before start of mock irradiation or irradiation under Panel $A$ and $B$ was set as 1.0. The tables below in Panel $A$ and $B$ summerize the calculated specific growth delay times for the various treatments. 
Following established procedures in our laboratory $(19,24), 3$ daily exposures of 3 Gy were used starting 3 days after the single 6-track intratumoral infusion of the Ad vectors. As endpoints for the tumor growth experiments we defined the time in days required for two tumor volume doublings. Untreated U-373 MG tumors quadrupled in volume within 14 days (Figure $5 \mathrm{~A}$ ) requiring sacrifice of the animals between days 20 and 25 . This growth rate was only minimally retarded by the infusion of control Ad-LacZ vector (16 days) that was also used to quantify the in vivo transduction rates of $70 \%(+/-5 \%)$ on day 3 after infusion, the time of the first radiation exposure. Ad-EGFRCD533 infusion alone resulted in a marginal growth delay of 2 tumor doublings to 21 days. Irradiation alone at $3 \times 3$ Gy delayed tumor growth to approximately 34 days (Figure 5 A). Importantly, there was a significant additional growth delay when irradiation was combined with the infusion of Ad-EGFR-CD533 ( $\mathrm{P}=0.014$ ); these tumors required 60 days to quadruple in volume (Figure $5 \mathrm{~A}$ ) representing a 2.2-fold enhancement in growth delay (31). This data demonstrates the lack of toxicity of Ad infusion into tumors and confirms a greater than additive radiosensitization when EGFR-CD533 expression is combined with irradiation. Since the tumors express both EGFRvIII and EGFR-CD533 throughout the growth delay experiments (Figure $4 \mathrm{~B}$ ), in vivo expression of intrinsic EGFRvIII was apparently neutralized by EGFR-CD533.

In order to quantify the inhibition of EGFRvIII by EGFR-CD533 further, experiments shown in Figure $5 \mathrm{~A}$ were repeated under conditions of high EGFRvIII expression. In these growth delay experiments (see Figure $5 \mathrm{~B}$ ) tumors were infused with Ad-EGFRvIII plus Ad-LacZ, Ad-EGFRvIII plus Ad-EGFR-CD533 or Ad-LacZ plus Ad-EGFR-CD533 (for protein expression of the two mutant receptors see Figure $4 \mathrm{C}$ ). All tumors were subjected to the same $3 \times 3$ Gy irradiation schedule. Tumors infused with Ad-LacZ plus Ad-EGFRvIII underwent two tumor volume doublings within 17 days (Figure $5 \mathrm{~B}$ ). This tumor growth pattern replicated the growth of untreated U-373 MG tumors (see Figure $5 \mathrm{~A}$ ). The combined infusion of Ad-EGFR-CD533 and AdEGFRvIII significantly delayed tumor growth to approximately 48 days ( $\mathrm{P}=0.003$; Figure $5 \mathrm{~B}$ ). This growth rate was further delayed to 74 days by expression of EGFR-CD533 after combined AdLacZ/Ad-EGFR-CD533 infusion, conditions under which tumors only express basal levels of EGFRvIII; however, this difference did not reach significance $(P=0.147)$. Importantly, the significant growth delay observed under simultaneous high expression of EGFR-CD533 and EGFRvIII affirmed the potent inhibitory effect of EGFR-CD533 on EGFRvIII (Figure 5 B).

In summary, our results demonstrate that the radiosensitiziation of U-373 MG tumors mediated by EGFR-CD533 was independent of the EGFRvIII expression levels thus suggesting a functional dominance of EGFR-CD533. This data lends additional support to the effectiveness and feasibility 
of using Ad-EGFR-CD533-mediated gene therapy to counteract EGFRwt- and EGFRvIII-mediated radioprotective effects.

\section{IV.2.4. Discussion}

The data presented supports previous findings that the most common mutant variant of EGFR, EGFRvIII, is widely expressed in xenograft tumors as shown here for the malignant U-373 MG glioma cells, and that the receptor is rapidly down-regulated when tumor cells are maintained under tissue culture conditions. The high level of EGFRvIII basal Tyr phosphorylation, relative to that of EGFR wt, is reflective of the constitutive activity of this mutant receptor and is the likely reason for its pronounced 2- to 3-fold stimulation after radiation exposure of cells. Previous findings suggesting the inability of EGFRvIII to interact with other ErbB receptors prompted our in vitro and in vivo studies to investigate the activity of EGFR-CD533 in inhibiting basal and radiation-induced Tyr phosphorylation of EGFRvIII. Using most stringent conditions of EGFR-CD533 and EGFRvIII over-expression (administered as Ad vectors) in U-373 MG xenograft tumors in nude mice, EGFRCD533 quantitatively counteracted the enhanced tumorigenic activity of EGFRvlII, inhibited its radiation-induced activation and eliminated its effects on tumor radioresistance. These results extend the potential therapeutic inhibition of radiation-induced ERBB receptor activation (and consequential radioresistance) to also include the constitutively active EGFRvIII.

Expression of mutant forms of the EGFR has been implicated in the progression of many human tumors $(32,33)$. Previous reports indicate, that EGFRvIII is expressed in a high proportion of human tumors, including malignant gliomas, breast and ovarian carcinomas (29). We have tested two different tumor types for the presence of EGFRvIII and demonstrated the consistent expression of this common EGFR variant at protein levels similar to or exceeding those of EGFRwt. Therefore, EGFRvIII represents a potentially powerful modulator of cellular radiation responses $(4,10,32$, 34).

Few mechanistic studies defining the function of EGFRvIII have been reported since its expression in vivo is limited to human spontaneous or xenograft tumors. Its rapid expression loss upon transfer of cells to in vitro conditions (4) was affirmed by our data demonstrating that EGFRvIII expression was lost (see Figure 1 and data not shown). These findings are presented for malignant glioma cells but also apply to human A431 squamous and MDA-MB-231 mammary carcinoma cells (G. Lammering et al, unpublished results). The mechanisms of growth environment-dependent expression of EGFRvIII are currently unknown (35). Consequently, the investigation of the truncated receptor described in this study concentrates on the analyses of human xenograft tumors, 
which also represent a more meaningful model for functional studies on the role of EGFRvIII and EGFR-directed biological therapies. The high constitutive activity levels of EGFRvIII relative to EGFRwt found in this study are consistent with other data demonstrating the oncogenic activity of EGFRvIII including neoplastic transformation and enhanced tumorigenicity $(3,4,36)$.

In agreement with these data, our studies also revealed that malignant glioma cells expressing EGFRvIII demonstrated greatly enhanced tumorigenic capacity when implanted into nude mice subcutaneously (see Figure $3 \mathrm{~A}$ and $\mathrm{B}$ ). Since this accelerated tumor cell growth takes place in vivo and not in vitro, these results suggest that EGFRvIII might play a role in the interaction of tumor cells with their environment rather than directly on cell growth. Tumors at this early point of growth are dependent on neovascularization and perhaps the signals transduced by EGFRvIII might enhance the ability of the tumor cells to induce this process $(3,6)$. Previous analyses showed that the EGFRvIII- induced enhanced tumorigenicity as demonstrated is dependent on its intrinsic tyrosine kinase activity (3). Since our data demonstrate that EGFR-CD533 expression significantly reduces the basal tyrosine kinase activity of EGFRvIII (Figure $2 \mathrm{~B}$ ) and completely eliminates tumor growth (Figure $3 \mathrm{~B}$ ), it is possible that EGFR-CD533 interaction with EGFRvIII modulates the described signals transduced by EGFRvIII to induce the process of neovascularization. However, based on our data we cannot entirely exclude the possiblity that the anti- tumor effects of EGFR-CD533 described are independent of EGFRvIII with a lack of specificity.

We have shown that the endogenous, constitutively active EGFRvIII in human xenograft tumors is activated by ionizing radiation to a similar extent as EGFRwt (Figure 1C). Based on its higher constitutive activity, EGFRvIII can be expected to initiate a stronger cytoprotective response in irradiated cells than we have previously demonstrated for EGFRwt $(14,17,19,24,27,30)$ and other ErbB receptors (37). Thus, EGFRvIII will significantly contribute to cellular radioresistance $(20,38)$ that is mediated by radiation-induced proliferation (17), anti-apoptosis $(20,38)$, and enhanced DNA repair $(17,24,27,39)$. These cellular responses have been linked through EGFRwt, and now EGFRvIII, to amplified signals at the levels of MAPK (40), PI3K (41), JNK (36) and transcription factors (42). The prominent, radiation-induced activation of EGFRvIll over EGFRwt with amplified signals of MAPK and AKT has also been demonstrated in a more defined system of $\mathrm{CHO}$ cells (20). The functional link between cytoprotective pro-survival responses of the ERBB/MAPK/AKT cascades with increased radioresistance $(17,24,27)$ emphasize the importance of inhibiting EGFRvIII for tumor cell radiosensitization. Our findings that the expression of EGFRCD533 can reduce basal and abrogate radiation-induced Tyr phosphorylation of both EGFRwt and EGFRvIII suggests that the interference of DN EGFR-CD533 with ERBB receptor activation 
includes EGFRvIII (43) and may be due to protein-protein interactions between the two receptors (4).

In summary, we have demonstrated that EGFR-CD533 acts as a potent inhibitor of EGFRvIII function, a constitutively active mutant receptor, expressed in many human tumors, that enhances tumor cell radioresistance. Ionizing radiation produces a significant activation of EGFRvIII in vivo and induces a more powerful cytoprotective response in tumors than has been previously demonstrated for EGFRwt $(14,24,27)$. The highly effective inhibition of EGFRvIII by EGFRCD533 likely occurs through receptor-protein-interactions as demonstrated for EGFRwt, since EGFR-CD533 eliminated the radiation-induced increase in Tyr phosphorylation of both EGFRvIII and EGFRwt. Importantly, EGFR-CD533 abrogated the tumorigenic capacity and relative radioresistance conferred by EGFRvIII when expressed at endogenous levels or upon Ad-mediated over-expression. Thus, the disruption of EGFRvIII function through the genetic approach of EGFR-CD533 over-expression represents a potentially powerful tool of mutant receptor inhibition and affirms the broad inhibitory activity of EGFR-CD533 towards ERBB receptors and its variants. 


\section{IV.2.5. References}

1. Ekstrand AJ, Sugawa N, James CD, Collins VP. Amplified and rearranged epidermal growth factor receptor genes in human glioblastomas reveal deletions of sequences encoding portions of the $\mathrm{N}$ and/or C-terminal tails. Proc Natl Acad Sci U S A, 89: 4309-4313, 1992.

2. Frederick L, Wang XY, Eley G, James CD. Diversity and frequency of epidermal growth factor receptor mutations in human glioblastomas. Cancer Res, 60:1383-1387, 2000.

3. Huang HS, Nagane M, Klingbeil CK et al. The enhanced tumorigenic activity of a mutant epidermal growth factor receptor common in human cancers is mediated by threshold levels of constitutive tyrosine phosphorylation and unattenuated signaling. J Biol Chem, 272: 2927-2935, 1997.

4. Moscatello DK, Montgomery RB, Sundareshan P, McDanel H, Wong MY, Wong AJ. Transformational and altered signal transduction by a naturally occurring mutant EGF receptor. Oncogene, 13: 85-96, 1996.

5. Nagane M, Coufal F, Lin H, Bogler O, Cavenee WK, Huang HJ. A common mutant epidermal growth factor receptor confers enhanced tumorigenicity on human glioblastoma cells by increasing proliferation and reducing apoptosis. Cancer Res, 56: 5079-5086, 1996.

6. Nishikawa R, Ji XD, Harmon RC, et al. A mutant epidermal growth factor receptor common in human glioma confers enhanced tumorigenicity. Proc Natl Acad Sci U S A, 91: 7727-7731, 1994.

7. O'Rourke DM, Nute EJ, Davis JG, et al. Inhibition of a naturally occurring EGFR oncoprotein by the p185neu ectodomain: implications for subdomain contributions to receptor assembly. Oncogene, 16 : 1197-1207, 1998.

8. Batra SK, Castelino-Prabhu S, Wikstrand CJ, et al. Epidermal growth factor ligand-independent, unregulated, cell-transforming potential of a naturally occurring human mutant EGFRvIII gene. Cell Growth Differ, 6: 1251-1259, 1995.

9. Humphrey PA, Wong AJ, Vogelstein B, et al. Anti-synthetic peptide antibody reacting at the fusion junction of deletion-mutant epidermal growth factor receptors in human glioblastoma. Proc Natl Acad Sci U S A, 87: 4207-4211, 1990.

10. Wong AJ, Ruppert JM, Bigner SH, et al. Structural alterations of the epidermal growth factor receptor gene in human gliomas. Proc Natl Acad Sci U S A, 89: 2965-2969, 1992.

11. Yamazaki H, Ohba Y, Tamaoki N, Shibuya M. A deletion mutation within the ligand binding domain is responsible for activation of epidermal growth factor receptor gene in human brain tumors. Jpn J Cancer Res, 81: 773-779, 1990.

12. Carter $\mathrm{S}$, Auer KL, Reardon DB, et al. Inhibition of the mitogen activated protein (MAP) kinase cascade potentiates cell killing by low dose ionizing radiation in A431 human squamous carcinoma cells. Oncogene, 16: 2787-2796, 1998.

13. Kavanagh BD, Lin PS, Chen P, Schmidt-Ullrich RK. Radiation-induced enhanced proliferation of human squamous cancer cells in vitro: a release from inhibition by epidermal growth factor. Clin Cancer Res, 1: 1557-1562, 1995.

14. Schmidt-Ullrich RK, Dent P, Grant S, Mikkelsen RB, Valerie K. Signal transduction and cellular radiation responses. Radiat Res, 153: 245-257, 2000.

15. Kashles, O., Yarden, Y., Fischer, R., Ullrich A, Schlessinger J. A dominant negative mutation suppresses the function of normal epidermal growth factor receptors by heterodimerization. Mol Cell Biol, 1l: 1454-1463, 1991.

16. Redemann, N., Holzmann, B., von Ruden, T., Wagner, E. F., Schlessinger, J., and Ullrich, A. Antioncogenic activity of signalling-defective epidermal growth factor receptor mutants. Mol Cell Biol, 12: 491-498, 1992.

17. Contessa, J. N., Reardon, D. B, Todd, D., et al. The inducible expression of dominant-negative epidermal growth factor receptor-CD533 results in radiosensitization of human mammary carcinoma cells. Clin Cancer Res, 5: 405-411, 1999.

18. Reardon, D. B., Contessa, J. N., Mikkelsen, R. B., et al. Dominant negative EGFR-CD533 and inhibition of MAPK modify JNK1 activation and enhance radiation toxicity of human mammary carcinoma cells. Oncogene, $18: 4756-4766,1999$.

19. Lammering, G., Hewit, T. H., Hawkins, W. T., et al. Epidermal growth factor receptor as a genetic therapy target for carcinoma cell radiosensitization. J Natl Cancer Inst, 93: 921-929, 2001.

20. Lammering, G., Hewit, T., Valerie, K., et al. EGFRvIII-mediated radioresistance through a strong cytoprotective response. Oncogene, 22: 5545-53, 2003. 
21. Valerie, K., Brust, D., Farnsworth, J., et al. Improved radiosensitization of rat glioma cells with adenovirus-expressed mutant herpes simplex virus-thymidine kinase in combination with acyclovir. Cancer Gene Ther, 7: 879-884, 2000.

22. Valerie, K., Hawkins, W., Farnsworth, J., et al. Substantially improved in vivo radiosensitization of rat glioma with mutant HSV-TK and acyclovir. Cancer Gene Ther, 8: 3-8, 2001.

23. Brust, D., Feden, J., Farnsworth, J., Amir, C., Broaddus, W. C., and Valerie, K. Radiosensitization of rat glioma with bromodeoxycytidine and adenovirus expressing herpes simplex virus-thymidine kinase delivered by slow, rate-controlled positive pressure infusion. Cancer Gene Ther, 7: 778-788, 2000 .

24. Lammering, G., Valerie, K., Lin, P. S., et al. Radiosensitization of malignant glioma cells through overexpression of dominant-negative epidermal growth factor receptor. Clin Cancer Res, 7: 682$690,2001$.

25. Schmidt-Ullrich, R. K., Mikkelsen, R. B., Dent, P., et al. Radiation-induced proliferation of the human A431 squamous carcinoma cells is dependent on EGFR tyrosine phosphorylation. Oncogene, 15: 1191-1197, 1997.

26. Dent, P., Reardon, D. B., Park, J. S., et al. Radiation-induced release of transforming growth factor alpha activates the epidermal growth factor receptor and mitogen-activated protein kinase pathway in carcinoma cells, leading to increased proliferation and protection from radiation-induced cell death. Mol Biol Cell, 10: 2493-2506, 1999.

27. Lammering, G., Lin, P. S., Contessa, J. N., Hampton, J. L., Valerie, K., and Schmidt-Ullrich, R. K. Adenovirus-mediated overexpression of dominant negative epidermal growth factor receptor-CD533 as a gene therapeutic approach radiosensitizes human carcinoma and malignant glioma cells. Int $\mathrm{J}$ Radiat Oncol Biol Phys, 51: 775-784, 2001.

28. Lee, I., Kim, J. H., Levitt, S. H., and Song, C. W. Increases in tumor response by pentoxifylline alone or in combination with nicotinamide. Int J Radiat Oncol Biol Phys, 22: 425-429, 1992.

29. Moscatello, D. K., Holgado-Madruga, M., Godwin, A. K., et al. Frequent expression of a mutant epidermal growth factor receptor in multiple human tumors. Cancer Res, 55: 5536-5539, 1995.

30. Schmidt-Ullrich, R., Contessa, J., Lammering, G., Amorino, G and P.S. Lin. Receptor tyrosine kinases and cellular responses to ionizing radiation. Oncogene Reviews, 22:5855-5865, 2003.

31. Kirichenko, A. V., Rich, T. A., Newman, R. A., and Travis, E. L. Potentiation of murine MCa-4 carcinoma radioresponse by 9-amino-20(S)-camptothecin. Cancer Res, 57: 1929-1933, 1997.

32. Ekstrand, A. J., Longo, N., Hamid, M. L., et al. Functional characterization of an EGF receptor with a truncated extracellular domain expressed in glioblastomas with EGFR gene amplification. Oncogene, 9: 2313-2320, 1994.

33. Wong, A. J., Bigner, S. H., Bigner, D. D., Kinzler, K. W., Hamilton, S. R., and Vogelstein, B. Increased expression of the epidermal growth factor receptor gene in malignant gliomas is invariably associated with gene amplification. Proc Natl Acad Sci U S A, 84: 6899-6903, 1987.

34. Chu, C. T., Everiss, K. D., Wikstrand, C. J., Batra, S. K., Kung, H. J., and Bigner, D. D. Receptor dimerization is not a factor in the signalling activity of a transforming variant epidermal growth factor receptor (EGFRvIlI). Biochem J, 324 (Pt 3): 855-861, 1997.

35. Bigner, S. H., Humphrey, P. A., Wong, A. J., et al. Characterization of the epidermal growth factor receptor in human glioma cell lines and xenografts. Cancer Res, 50: 8017-8022, 1990.

36. Antonyak, M. A., Moscatello, D. K., and Wong, A. J. Constitutive activation of c-Jun N-terminal kinase by a mutant epidermal growth factor receptor. J Biol Chem, 273: 2817-2822, 1998.

37. Bowers, G., Reardon, D., Hewitt, T., et al. The relative role of ErbB1-4 receptor tyrosine kinases in radiation signal transduction responses of human carcinoma cells. Oncogene, 20: 1388-1397, 2001.

38. Contessa, J. N., Hampton, J., Lammering, G., et al. Ionizing radiation activates Erb-B receptor dependent Akt and p70 S6 kinase signaling in carcinoma cells. Oncogene, 21: 4032-4041, 2002.

39. Schmidt-Ullrich, R. K., Contessa, J. N., Dent, P., et al. Molecular mechanisms of radiation-induced accelerated repopulation. Radiat Oncol Investig, 7: 321-330, 1999.

40. Montgomery, R. B., Moscatello, D. K., Wong, A. J., Cooper, J. A., and Stahl, W. L. Differential modulation of mitogen-activated protein (MAP) kinase/extracellular signal-related kinase kinase and MAP kinase activities by a mutant epidermal growth factor receptor. J Biol Chem, 270: 30562 30566, 1995.

41. Moscatello, D. K., Holgado-Madruga, M., Emlet, D. R., Montgomery, R. B., and Wong, A. J. Constitutive activation of phosphatidylinositol 3 -kinase by a naturally occurring mutant epidermal growth factor receptor. J Biol Chem, 273: 200-206, 1998. 
42. Amorino, G. P., Mikkelsen, R. B., Valerie, K., and Schmidt-Ullrich, R. K. Dominant-negative CREB inhibits proliferating cell nuclear antigen and DNA repair, leading to increased cellular radiosensitivity. J Biol Chem, 278:29394-29399, 2003.

43. Lemmon, M. A. and Schlessinger, J. Regulation of signal transduction and signal diversity by receptor oligomerization. Trends Biochem Sci, 19: 459-463, 1994. 


\section{Chapter V}

\section{Summary}

General discussion

Future perspectives 


\section{V.1 Summary}

The epidermal growth factor receptor and the other ErbB receptor- tyrosine kinases play an important role in the neoplastic growth control of many carcinoma and glioma cells (1-4). This is a result of the activation of receptor tyrosine kinases with secondary stimulation of downstream signal transduction pathways (4). As in the case with other growth factor receptors, an increase in EGFR expression can be the result of gene amplification, increased transcription, mRNA translation or mutation. This leads to an unregulated increased receptor signal. For many carcinomas and gliomas an increased EGFR activity is correlated with neoplastic progression and enhanced tumor growth $(5,6)$. The overexpression of EGFR in autocrine growth regulated carcinoma and glioma cells as part of the neoplastic progression is frequently associated with the expression of mutant forms $(5,7-10)$. The most frequent EGFR mutation is a variant called EGFRvIII, which is the result of a deletion of exons 2-7 of the EGFR gene (8). This deletion results in a receptor with a constitutively active tyrosine kinase which ligand- independently can induce cell transformation $(6,11)$. EGFRvIII is only present on the cell surface of tumors, but not detectable in normal tissue $(5,7)$. Another results from the observation that this receptor is only expressed in vivo in tumor cells and is rapidly down regulated in cultured tumor cells in vitro. Therefore, to date mechanistic studies to elucidate the unique functions of EGFRvIII have been limited

Previous studies demonstrated that irradiation of tumor cells can result in an immediate activation of the ErbB-family of receptors and that repeated radiation exposures of 2 Gy lead to an increased expression of EGFR (12-14). This radiation- induced activation of EGFR is defined by a severalfold increase in the tyrosine phosphorylation with a secondary activation of existing signalling transduction cascades of MAPK and PI-3-K (12,15-17). The radiation- induced activation of the EGFR family of receptors leads to a dose-dependent proliferative response, which can be observed after single, as well as repeated radiation exposures $(13,16,18)$. It has therefore been concluded that the radiation- induced activation of EGFR is involved in the mechanism of accelerated proliferation or repopulation. This cellular proliferative response after repeated radiation exposures leads to increased renewal of tumor clonogens $(19,20)$. Considering the increased biosynthetic activity of rapidly proliferating tumor cells, it can be assumed that this will lead to an improved capacity for DNA damage repair.

Because the radiation- induced proliferative as well as the improved DNA repair responses of tumor cells counteract the toxic effects of radiotherapy, we have defined them as EGFR-family-induced cytoprotective responses of tumor cells. Considering the special role of the EGFR family in 
initiating these cytoprotective responses following radiation, disruption of ErbB receptor function should prevent the cytoprotective responses and therefore mediate tumor cell radiosensitization.

The thesis project presented herein is based on the hypothesis that the inhibition of the radiationinduced activation of the EGFR family can improve the radiosensitivity of tumor cells independent of their varying ErbB expression profiles. In order to effectively block the function of the EGFR family of receptors, we used a genetic approach of adenoviral overexpression of a dominantnegative EGFR, called EGFR-CD533 (Figure 1.1.5). EGFR-CD533 has the advantage that it does not only inhibit the function of EGFR itself, but also the function of the whole ErbB receptortyrosine kinase network and also the function of naturally occurring mutant EGFR species.

First of all it was important to clarify the relative role of the ErbB 1-4 receptor tyrosine kinases in radiation signal transduction responses of human tumor cells. Previously, the downstream consequences of the radiation- induced activation of the ErbB receptors were thought to be indistinguishable from those obtained with growth factors. In order to identify potential differences of downstream consequences between the effects of growth factor and radiation, we compared the effects in mammary carcinoma cell lines differing in their ErbB expression profiles. As an important finding we were able to demonstrate that in contrast to treatment of cells with growth factors with ErbB 1 or ErbB4 specificity, which resulted in hierarchic transactivations of ErbB2 and ErbB3, radiation indiscriminately activated all ErbB species with the activation profile reflecting the cells' ErbB expression profile (Chapter II.1). Furthermore, ErbB 2 was identified as a modulator of ErbB 1 or ErbB4 leading to different downstream MAPK response profiles to radiation exposure (Chapter I1.1). Therefore, our data demonstrated for the first time that ErbB expression profiles of human carcinoma cells could influence ErbB receptor activation in response to ionizing radiation. Thus, therapeutic interventions to radiosensitize human tumor cells should consider inhibition of the function of the entire ErbB receptor- tyrosine kinase network in order to effectively improve radisensitivity independent of the varying ErbB expression profiles. This encouraged us to further move on with the development of a genetic approach of inhibiting the ErbB receptor tyrosine network through expression of dominant-negative EGFR-CD533.

We therefore further investigated the capacity of a gene therapeutic approach of using replicationincompetent adenovirus- mediated transfer of EGFR-CD533 to enhance the radiosensitivity by examining the direct radiosensitization in vitro for a broad spectrum of different tumor cell lines representing varying expression profiles of the ErbB receptors (Chapter II.2). After having characterized all tested cell lines for their different ErbB receptor expression profile and after 
having optimized the experimental conditions for adenoviral gene transfer of EGFR-CD533, our experiments revealed complete inhibition of radiation- induced activation of EGFR upon EGFRCD533 expression. Clonogenic survival analyses linked the expression of EGFR-CD533 to a significant increase in the intrinsic radiosensitivity for all tested cell lines after single as well as repeated radiation exposure experiments (Chapters II.2, III.2). Thus, our data provided evidence that all cell lines tested can be effectively transduced to express EGFR-CD533 by a gene therapeutic approach using Ad-EGFR-CD533 and are effectively sensitised to ionizing radiation.

These results prompted us to further test our gene therapeutic approach in xenograft tumors in vivo. We therefore introduced the adenoviral vector containing EGFR-CD533 into xenograft tumors in nude mice and evaluated whether the percentage of transduced tumor cells achieved can influence the tumor response to ionizing radiation. Furthermore, we tightly associated data from in vivo/ in vitro experiments in order to examine whether the mechanism underlying the radiosensitization in vitro also apply to the mechanism in vivo. To determine the susceptibility of U-87 MG cells and MDA-MB-231 cells to transduction with adenovirus, we first established the optimal transduction conditions by use of the Ad-LacZ reporter virus gaining an overall $59-65 \%$ and $44 \%$ transduction efficiency, respectively (Chapter III). Under these conditions, intratumoral infusion of Ad-EGFRCD533 resulted in a significant radiosensitization, yielding a dose-enhancement ratio of 1.8 and 1.85 after 3 repeated radiation exposures of 3 and 1.5 Gy for U-87 MG and MDA-MB-231 tumors, respectively, which was comparable to the extent of radiosensitization conferred with cells from MDA-EGFR-CD533 tumors, in which all of the cells are engineered to stably overexpress EGFRCD533 (Chapter III.3). These data provided evidence that a gene therapeutic approach of overexpressing a dominant- negative EGFR-CD533 by use of in vivo adenoviral vector delivery can effectively radiosensitize xenograft tumors after repeated radiation exposures. The mechanisms underlying this radiosensitization occurs by the same mechanisms in xenograft tumors as in cultured cells, thus affirming the therapeutic potential of this approach (Chapter III.3).

Another important aspect of our thesis project presented herein included investigations on the modulating effects of EGFRvIII on acute cellular radiation responses and possible influences on tumor cell survival after irradiation. As EGFRvIII is not expressed in cultured cells, we first performed these mechanistic studies in a transient transfection CHO cell system (Chapter IV.1). As expected, EGF activated EGFRwt with no effect on EGFRvIII. In contrast, a single radiation exposure of 2 Gy resulted in an immediate $4.3-$ fold increase in Tyr phosphorylation, which immediately induces secondary downstream increases in MAPK and Akt activity, by far exceeding the increases induced by radiation-induced EGFRwt activation (Chapter IV.1). Consequently, 
radiation- induced activation of EGFRvIII resulted in an effective modulation of $\mathrm{CHO}$ cell radiosensitivity, thus identifying EGFRvIII as another important target for tumor cell radiosensitization (Chapter IV.1). In order to next enable investigations of EGFRvIII function in human malignant glioma cells in vitro, also taking into account the frequent expression of EGFRvIII in malignant glioma tumors, we developed an adenoviral vector to overexpress EGFRvIII in cultured cells in vitro. In addition, we examined EGFRvIII function under conditions of intrinsic expression in xenograft tumors and furthermore explored the feasibility of Ad-EGFRCD533 for inhibiting EGFRvIII function in vitro and in vivo. Our studies revealed that ionizing radiation produces a significant activation of EGFRvIII in vivo, which induces a more powerful cytoprotective response in tumors than previously demonstrated for EGFRwt (Chapter IV.2). Importantly, EGFR-CD533 was demonstrated to also act as a potent inhibitor of EGFRvIII function, abrogating the tumorigenic capacity and the relative radioresistance conferred by EGFRvIII (Chapter IV.2).

In summary, we have demonstrated for the first time that functional inhibition of the ErbB receptor tyrosine kinases through dominant- negative EGFR-CD533 leads to a significant radiosensitization for a broad spectrum of different tumor cells independent of the varying ErbB receptor expression levels. The mechanisms underlying this radiosensitization involve disruption of major ErbB receptor- dependent radiation-induced pro- proliferative and cytoprotective responses, which would normally counteract the toxic effects of radiation through an improved DNA damage repair capacity as a result of the increased biosynthetic activity (Chapter II). Consequently, the further developed gene therapeutic approach of intratumoral application of Ad-EGFR-CD533 into human carcinoma and malignant glioma xenograft conferred a dominant-negative EGFR phenotype and effectively induced tumor radiosensitization by the same mechanisms as in cultured cells (Chapter III). Thus, overexpression of EGFR-CD533 may hold promise to enhance the sensitivity of tumor cells to ionizing radiation.

Furthermore, our studies identified the frequently in many different tumor entities expressed naturally occurring variant of EGFR, EGFRvIII as an important modulator of tumor cell radiosensitivity. This can be explained through a strong radiation-induced activation of EGFRvIII, conferring a more intense downstream activation of pro-proliferative and anti-apoptotic MAPK and PI3K signalling cascades leading to a stronger cytoprotective response to radiation than previously known for EGFRwt. Importantly, our studies also assessed that expression of EGFR-CD533 effectively inhibits this EGFRvIII function, thus affirming the broad potential of EGFR-CD533 to radiosensitize human tumors (Chapter IV). 
Our data confirm that the genetic inhibition of the radiation- induced activation of the ErbB receptor tyrosine kinases as well as the variant EGFRvIII through dominant-negative EGFR-CD533 represents an effective and broadly applicable new therapeutic intervention for tumor cell radiosensitization. It should therefore be further developed as a promising gene therapeutic innovation for the treatment of cancer through tumor cell radiosensitization

\section{V.2. General discussion}

We and others have presented data supporting the hypothesis that radiation- induced activation of ErbB receptors results in cytoprotective signalling that mediates proliferative and biosynthetic responses (13,16,21-24). This ErbB function can be effectively modulated by a gene therapeutic approach of over-expressing dominant-negative EGFR by use of adenoviral delivery, leading to tumor cell radiosensitization after single and repeated radiation exposures both in vitro and in vivo (Chapter III.3).

Since EGFR and the ErbB receptors have emerged as promising targets in radiotherapy, extensive research activity explores potential procedures to target EGFR, the other ErbB receptors and /or its downstream pathways for radiotherapy to enhance radiation action in human carcinomas and malignant gliomas. Over the past several years, it has been recognized that beside our gene therapeutic intervention, antibodies and small- molecule inhibitors can be used therapeutically to disturb EGFR and/or ErbB signalling at the cellular level. These approaches include monoclonal antibodies directed against the receptors, synthetic tyrosine kinase inhibitors that act directly on the cytoplasmic domain of EGFR and / or other ErbB molecules.

\section{V.2.1 The antibody approach}

Various groups have generated a number of antibodies directed against EGFR. Two such antibodies, M225 and M528, were found to compete with EGF binding, inhibit EGF-induced tyrosine kinase-dependent phosphorylation, and downregulate EGFR expression by inducing

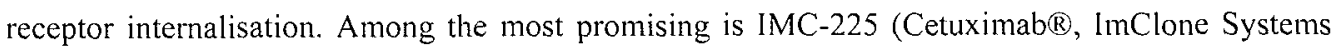
Incorporated, NY,NY, and Bristol-Mayers Squibb Company, Princeton, NJ), a humanized M225, which has a higher affinity for EGFR with a longer half-life (25-27, Review). Another antibody approach, in preclinical trials, targets the novel epitope created by alternative splicing in the EGFRvill mutation (28 review). 
Studies using A431 human carcinoma xenograft in nude mice combined IMC-C225 with local tumor radiation demonstrated enhanced tumor radioresponse by a factor of 1.6 when a single dose of IMC-C225 was used and 3.6 when 3 doses of IMC-C225 were used (29). Other groups have also recently published preclinical studies confirming the significant enhanced clinical response in a wide spectrum of epithelial human tumor xenograft when receiving the combination of radiation plus IMC-C-225 (8,30-34). Interestingly, the interactions of IMC-C225 and radiation were more profound in vivo than initially predicted by in vitro studies, suggesting that mechanisms beyond simple proliferative growth inhibition are acting in the in vivo setting [reviewed in 35]. Multiple mechanisms seem to underlie the enhancement of tumor response to radiation by IMC-C225 involving both direct and indirect interaction with tumor cells. They may include IMC-C225 induced inhibition of DNA damage repair, enhanced radiosensitivity originating from specific disturbances in cell cycle phase distribution, enhancement of radiation-induced apoptosis, inhibition of tumor angiogenesis, and effects on tumor cell migration and invasion capacity (reviewed in 36 ). EGFR has been shown to physically interact with DNA-dependent protein kinase (DNA-PK) (37). Huang et al. reported that treatment with IMC-C225 could cause redistribution of DNA-PK from the nucleus to the cytosol resulting in reduced radiation- induced DNA damage repair (31). IMCC225 significantly inhibits formation of new vessels at the site of A431 tumor cell inoculation, suggesting a direct inhibitory effect of IMC-C225 on tumor angiogenesis possibly through inhibition of mRNA and protein production of angiogenic factors (29,38). In contrast, the mechanisms by which IMC-C225 inhibits EGFR at the protein level are not fully understood. For example, it hasn't been investigated whether the radiosensitising effects of IMC-C225 might also be explained by the blockade of EGFR heterodimers formation and receptor cross talk which would support a critical involvement of other ErbB family members and other growth factors and their receptors in the enhanced radiosensitivity. If studies investigating the mechanism of IMC-C225 reveal that IMC-C225 targets only EGFR without functional interference with other ErbB receptor family members, the ultimate broad clinical application of this approach could be limited.

Meanwhile, the first results of a large phase III trial combining the treatment of IMC-C225 with radiotherapy for head and neck cancer have just been presented demonstrating an almost doubling in median survival compared to radiotherapy alone. More of the IMC-C225 patients were alive at three years ( $57 \%$ vs. $44 \%$ ) compared to the RT only group. The IMC-C225 was very well tolerated, with skin reactions noted as the most common side effect (39). This new regimen thus represents a promising new treatment for head and neck cancer and demonstrates for the first time the 
significant curative advantage of the combination of a molecularly targeted anti-EGFR approach with radiotherapy for the treatment of solid tumors in a clinical phase III trial.

\section{V.2.2 The small molecule approach}

There exist a growing number of EGFR/ErbB inhibitory small molecule compounds in various stages of preclinical and clinical development. Several classes of small- molecule tyrosine- kinaseinhibitor compounds have been developed including quinazolines, pyrazolo-, pyrido-, and pyrrolopyrimidines, which are the furthest forward in development. For tyrosine kinase inhibitors to be used therapeutically, they must be highly specific. The inhibitors studied to date have varying levels of specificity. Several quinazoline derivates have been developed that are more selective for EGFR than for other tyrosine kinase receptors. They act by competitively inhibiting ATP binding (40). ZD1839 (Iressa $($ ), Astra Zeneca, Wilmington, DE) is an anilinoquinazoline with an IC50 of 20 $\mathrm{nM}$ for the EGFR tyrosine kinase. It binds reversibly to EGFR tyrosine kinase. OSI-774 (Erlotinibß, formerly $\mathrm{CP} 358,774$ ) is a quinazoline analog with a nanomolar IC50 for reversible inhibition of EGFR activity and high specificity for the receptor (41). CI-1033 is a novel quinazoline that irreversibly inhibits EGFR and ErbB 2 tyrosine kinases. As a result, this compound seems to function as a pan-ErbB tyrosine kinase inhibitor. Finally, PKI-166 represents a potent pyrrolopyrimidine competitively reversibly binding to the ATP binding site of EGFR and ErbB2 tyrosine kinases.

Distinct from the monoclonal antibody approach, which attacks the extracellular ligand- binding domain of EGFR, the small molecule inhibitors, the best-known being ZD 1839, OSI-774 and CI1033 are directed against the cytoplasmic tyrosine kinase domain of EGFR and partially other ErbB tyrosine kinases. Just as with IMC-C225, there is solid preclinical data regarding the capacity of ZD1839 and CI-1033 to enhance radiation efficacy in both in vitro and in vivo model systems (4245). ZD1839 is an orally bioavailable active EGFR inhibitor. It has been proven to enhance the cytotoxicity of radiation across a spectrum of human cancer cell lines including lung, pancreas, malignant glioma, colon and head and neck (45-48). For human colon carcinoma xenograft, the combination of ZD1839 with radiation enhanced the therapeutic effect compared with radiation alone by a factor of 1.6 (45). Growth delay assays with ZD1839 in combination with radiation for human squamous cell carcinomas revealed a significant synergistic tumor growth inhibition effect (42). In line with these data on ZD1839 and radiotherapy, Baumann and colleagues also found improvement of growth delay with BIBX1382BS, which is also an inhibitor like ZD1839 in combination with radiation for $\mathrm{FaDu}$ human squamous cell carcinoma. However, they could also 
clearly demonstrate that despite the antiproliferative activity in these rapidly repopulating $\mathrm{FaDu}$ cells and the significantly increased tumour growth delay, local tumour control was not improved (49). These findings highlight that significant effects on tumour growth delay do not necessarily reflect the efficacy of anti-EGFR small molecule inhibitors in combination with radiation on curative potential (49). Furthermore, the effectivity of this combination on tumour cell radiosensitization might not only purely dependent on the presence of EGFR, but also on other cellular molecular characteristics, which are not easily understood at this point in time (50).

CI-1033 inhibits the tyrosine kinase activity of all 4 members of the ErbB family. Preclinical studies in ErbB- overexpressing human breast cancer cells identified a supra- additive effect of CI-1033 with radiation in the fractionated radiation setting (44). Beside the mechanism of inhibition of EGFR- induced cancer cell proliferation, small molecule tyrosine kinase inhibitors also seem to potentate the antitumor activity of radiation in part by effects on cellular apoptosis and angiogenesis (42). In contrast to IMC-C225, small molecule tyrosine kinase inhibitors of EGFR might also be active against the naturally occurring mutant of EGFR, called EGFRvIII, since EGFRvIII has an intact, intracellular kinase domain. This is particularly relevant because of the emerging importance of EGFRvIII in several human carcinomas and malignant gliomas $(5,7,10,51)$.

Despite the discouraging results of the combination of Iressa $($ with traditional chemotherapy for the treatment of non-small cell lung cancer, as shown recently by two large randomised clinical trials $(52,53)$, ZD1839 (Iressa $\left.{ }^{\circledR}\right)$ has now been approved as single-drug therapy for refractory lung cancer, because of a remarkably rapid and often profound response to Iressa $\AA$ in a subgroup of patients with refractory lung cancer $(54,55)$. The non- small cell lung cancers of those patients have now been identified as having specific mutations in the EGFR gene, which correlate with clinical responsiveness to the tyrosine kinase inhibitor Iressa $(56)$.

\section{V.2.3 Our genetic approach of using dominant-negative EGFR}

The overexpression of EGFR-CD533 disrupts the function of the entire ErbB receptor tyrosine kinase network through receptor-protein interactions, thus disabling radiation- induced activation of the ErbB receptors as well as cross talk with other receptor families (22, Chapter II). This gene therapeutic approach resulted in clear significant radiosensitization for a variety of different human carcinoma and malignant glioma cells despite the substantially different expression levels of EGFR and other ErbB receptors [Chapter I1.2]. Furthermore, it has been shown in vivo, that blocking receptor activation with the use of the EGFR-CD533 blocked radiation- induced signalling and 
decreased clonogenic survival of tumor cells in an excision assay in human breast cancer xenograft (Chapter 1II.3). The radiosensitivity of EGFR-CD533 transduced tumors yielded a doseenhancement ratio of 1.85 compared with control tumors (Chapter III.2). Interestingly, this enhanced cytotoxicity after radiation was achieved in a tumor cell line that, at baseline, does only express moderate levels of EGFR (Chapter III.3). Furthermore, EGFR-CD533 clearly proofed to be effective against the naturally occurring variant EGFR, EGFRvIII (Chapter IV). Although the use of a gene therapy approach with EGFR-CD533 clearly potentates the antitumor activity to radiation, it faces the problem of gene therapy techniques in general with the possibility of inadequate gene delivery leading to insufficient infection efficiency. Thus, it may be necessary to combine this gene therapy technique with one of the other approaches described to achieve complete inhibition of EGFR activation.

\section{V.2.4. Clinical trials combining anti-EGFR strategies and radiotherapy}

As described above, the rationale for targeting EGFR/ErbB in combination with radiation is established, but only clinical data can provide proof-of principle. However, the clinical development of anti-EGFR strategies to date has primarily concentrated on combination with cytotoxic chemotherapy. The first clinical trials to examine interactions of anti-EGFR approaches with radiation have now been finished. Clinical trials that incorporate IMC-C225 in radiotherapeutic regimens are active in the phase I/II/III setting for patients with epithelial malignancies. An international phase III trial for head and neck cancer patients has just completed enrolment of 416 patients randomised to either high-dose radiation alone or in combination with weekly infusion of IMC-C225 (reviewed in 36). The study to date shows, that IMC-C225 seems to be well tolerated, although some adverse events including fever, allergic reactions, and skin toxicity mostly as a follicular rush, have been reported (39). The first results have just been presented at the recent ASCO meeting demonstrating a prolonged survival in favour of the patients receiving highdose radiation with IMC-C225. Median survival was nearly twice as great in the IMC-C225 group (54 months versus 28 months) (39). The first clinical trials to examine ZD1839 together with radiation have just been started. A multicenter phase I trial of ZD1839 combined with radiation and chemotherapy will first test the feasibility and toxicity profile for the combination of ZD1839 with chemoradiation in locally advanced head and neck cancer patients. In addition, ZD1839 has also been incorporated in another phase I/II clinical trial in combination with radiation for patients with inoperable non-small cell lung cancer and glioblastoma multiforme. CI-1033 is in somewhat earlier phases of clinical testing. As with ZD1839, studies are underway to further explore the interaction of $\mathrm{CI}-1033$ with radiation in the clinical trials setting. The gene therapeutic approach of EGFR- 
CD533 overexpression together with radiation is currently in preparation as a clinical phase I/II trial for patients with glioblastoma multiforme. Although many clinical trials mature regarding the use of monoclonal antibodies and small molecule tyrosine kinase inhibitors in the treatment of patients with head and neck, colorectal, pancreatic, and lung cancers, a clinical proof for the ultimate role of EGFR inhibition in combination with radiation has to date only been established by one phase III trial combining IMC-C225 with radiotherapy for the treatment of head and neck cancer (39). More positive trials will hopefully follow soon.

\section{V.3. Future perspectives}

Although several promising approaches to disable EGFR/ErbB function are being explored and have already reached clinical testing in combination with radiation, many questions remain to be addressed. It is unclear, whether EGFR inhibition will be effective only in tumors that overexpress EGFR. Furthermore, it is uncertain, whether it is necessary to achieve complete EGFR blockade to prevent radiation- induced EGFR- dependent signalling and whether other ErbB receptors or other receptor families might counteract the radiosensitization induced by selective EGFR blockade due to possible compensatory events in fractionated radiation regimens. There is also a need for a better understanding of the optimal combinations and delivery schedule of EGFR modulators together with radiation. Therefore, further preclinical and clinical investigations are necessary to better explore mechanisms of action and efficacy of combined treatment modalities. The best approaches to target EGFR remains unclear although all anti-EGFR approaches described will certainly further improve our understanding of this important molecular target system.

The challenge in future research development will be to identify the appropriate inhibitor for the specific individual tumour. Thus, determine and understanding the mechanisms, by which a given cell line promotes cytoprotective responses to radiation is essential in optimising individualized molecularly targeted therapies. Further investigation of the mechanisms of the radiation response modulation by members of the ErbB receptor family will lead to optimisation of this promising therapeutic approach.

Our main research line for the following years regarding the family of EGFR receptors and ionizing radiation will involve both preclinical and clinical research:

\section{V.3.1. Future preclinical research}




\section{V.3.1.1. EGFRvIII research}

Our work presented in Chapter IV has indicated that EGFRvIII expression is restricted to cells growing in vivo as tumors. Based on first experiments, our hypothesis is that activation of ER stress during hypoxia promotes the selective expression of the EGFRvllI protein. We will therefore examine the importance of both hypoxia and ER stress on the transcription, translation and stability of both EGFR and EGFRvIII. Using genetic models we will define the molecular pathways responsible for the increased expression under these conditions. If our hypothesis proves correct, it would significantly alter our understanding of the mechanisms by which tumour hypoxia influences patient prognosis.

Another specific aim of our future research regarding EGFRvIII will be to characterize the consequences and the importance of EGFRvIII for tumour radiation responses, since it is unresponsive to ligand, but is activated by RT (Chapter IV). We will thus analyse the relevant phenotypical changes of different tumour cells following EGFRvIII activation, including changes in proliferation, cell survival, and angiogenesis. We will further characterize downstream pathways including the MAPK, JNK and PI3K pathways following EGFRvIII activation. This understanding is anticipated to aid in our ability to predict the outcome of EGFRvIII activation during RT and the potential for its inhibition in individual tumors.

\section{V.3.1.2. EGFR signalling pathway research}

The main objectives of our EGFR research over the next years will be to further evaluate the mechanisms of action and the potential of new biological modifiers targeting the EGFR signalling pathway alone or in combination with the EGFR inhibitors, described in Chapter V.2. This area of research will concern investigations into the interaction of novel therapeutics with the EGFR signalling pathway. For each new drug candidate, its specific molecular and phenotypic effects on these various downstream pathways will be evaluated. This research will be conducted with genetically matched cell line models that are defective in specific signalling elements of the pathways. Further studies will be done using a novel class of receptor tyrosine kinase inhibitors that can selectively inhibit several distinct pathways. This field is particularly interesting since it may be useful to target several molecular pathways at the same time to obtain a maximal anti-proliferative effect, anti-survival effect or anti-angiogenic effect especially when combined with irradiation. One of the compounds tested will be a combined EGFR and ErbB 2 agent, which will be evaluated in human tumors that express these two receptors at high levels. 
Furthermore, we will be actively involved in research regarding the phenotypical consequences of cellular hypoxia and novel inhibitors of this pathway. The involvement of the EGFR pathway and specifically the activation of the downstream pathway, which signals through PI3kinase and mTor, will be assessed as contributors to hypoxia tolerance. For example inhibition of the EGFR will be compared to the inhibition of mTor with rapamycin. Rapamycin is a specific inhibitor of $m$ Tor, a known kinase downstream of EGFR. The molecular pathways responsible for this interaction will be examined using cell line knockout or knockdown models of important hypoxia responsive genes. The importance of hypoxia and angiogenesis has been largely overlooked with respect to the consequences of EGFR inhibition.

\section{-EGFR inhibition and the genetic background}

As described in Chapter I, EGFR activates several downstream pathways that are also influenced by other parallel signalling pathways. Thus, an important element of our future research will also be to understand the influence of the genetic background on the efficiency of a particular drug. This will not only help in the evaluation of the therapeutic potential of a particular drug, but also in the development of theranostic tools, which will be important in the use of biological modifiers in the clinic. This relevance of tumour genotype for targeting EGFR will be examined on each of the downstream pathways that are potentially relevant for radiotherapy, including proliferation, radiosensitivity and hypoxia/angiogenesis.

\section{-EGFR family and cooperating and reciprocal interactions with other radiation responsive receptors}

EGFRvIII, the ErbB molecules, VEGFR and IGF-1R with overlapping pro- proliferative, antiapoptotic and angiogenic activities can, under certain conditions, transactivate each other. These reciprocal interactions in response to a cytotoxic challenge suggest compensatory survival responses when one or the other receptor tyrosine kinase activity is blocked. This could be one reason for possible failures apparent from combinations of EGFR-inhibition with radiotherapy in the clinical setting. Therefore, a detailed understanding at the molecular level of these possible interactions is necessary. Thus, this research aim will focus on interactions between EGFRvIII, the ErbB receptors, VEGFR and IGF-1R. Measurements of radiation- induced activation of downstream kinases with one or the other receptor tyrosine kinase downregulated pharmacologically or genetically through the use of dominant-negative EGFR-CD533 will provide a diagnostic footprint of the cooperating interactions of the ErbB receptors, VEGFR, IgF-IR and EGFRvIII upon radiation- induced cellular responses. 


\section{V.3.1.3 EGFR as therapy target - the development of imaging strategies and surrogate markers using proteomics}

This future research line results from the findings in recent years that EGFR and EGFRvIII have emerged as important targets to enhance the sensitivity of human malignant tumors to RT. The specificity of anti-EGFR agents however requires the presence of the target and individual and acquired resistance to these agents could become a potential clinical problem. Thus, tools like molecular / functional imaging and proteomics are needed to provide fast and simple methods to effectively analyse the presence of EGFR/EGFRvIII in tumors and to determine drug activity. Therefore we will develop antibodies to optically image for the presence and expression of EGFR/EGFRvIII. Furthermore, we will develop a tool to visualize the radiation- induced activation changes of EGFR/EGFRvIII. Finally, we will perform proteomics analysis in order to identify secreted proteins correlating with the radiation- induced activation of EGFR/EGFRvIII in human carcinoma cells. These novel putative surrogate markers will then be used to evaluate the therapeutic potential of EGFR-targeted agents in vivo. These novel imaging tools and proteomics surrogate markers would not only directly impact drug evaluation, but also impact in subsequent management for clinical trials testing anti-EGFR therapeutics in combination with RT.

\section{V.3.2. Future clinical research}

\section{- Retrospective analysis of patient material}

Currently, our understanding of the radiation- induced signalling events that regulate and are regulated by EGFR-dependent signal transduction pathways derives primarily from in vitro models and will be extended with the research described in Chapter V.3.1. Consequently, dissecting the molecular events associated with EGFR/EGFRvIII, MAPK and PI3K in cancer patients in vivo represents a critical extension of our work. In particular, it has important implications for the design of clinical trials with inhibitors for future individualized approaches of specific molecular targeted therapies in combination with RT. Therefore, we will analyse the predictive role of EGFR/EGFRvIII, the MAPK and the PI3K pathway in cancer patients in vivo treated with RT. Analysis will be performed using an immunohistochemical analysis applied to a tissue microarray. The development of phosphorylation-specific antibodies that allow detection of activated signalling molecules in paraffin-embedded tissues has enabled us to analyse these specific pathways. Having defined predictive biomarkers of radiation responses, we will validate these biomarkers in a prospective study by use of our biobank. The European Biobank of Maastricht is already actively collecting tumour material from a variety of different tumour entities, thus providing tissue material from a broad spectrum of different tumour sites. 


\section{- Clinical phase I-III trials}

A key scientific future perspective will be the launching of phase I-II clinical trials with novel drugs aimed at targeting elements of the EGFR family and/or its signalling pathway. We have focused on anti-EGFR inhibitors and / or key downstream pathways of EGFR activation, and the goal of these first clinical trials will be to begin the process of assessing their potential in patients. A key challenge facing translational researchers is in the design of effective clinical trials, which ensure a flow of information from the bedside back to the lab. With the realization that most trials will be negative coupled with the high costs of developing and testing new drugs, it is imperative that trials are designed with a goal to increase our basic understanding of cancer. One critical component of new trials is thus collection of biological tissue. In the case of classical negative trials, this tissue might be used to identify biological differences (genetic profiles), which identify a subset of patients who can benefit from the new treatment. Important in the design of the trials will be confirmation of the mechanisms of action as determined from basic and pre-clinical models. Collection of clinical material will be made to assess the status of the target pathway, the status of other confounding pathways identified in pre-clinical studies.

In addition to launching phase I-II trials, we are going to actively participate in multi-central phase III trials combining anti-EGFR strategies with RT. Biological material will also be used from these trials to determine as accurately as possible the mechanism of action of the drug, its ability to function in vivo and to illicit expected downstream processes. This information will then allow proper assessment not only of drug action, but also in the value to the chosen target or pathway. 


\section{V.4. References}

1. Weinberg, RA. Oncogenes and the molecular origin of cancer. Cold Spring Harbor, NY: Cold Spring Harbor Laboratory, 1989; 54-62

2. Baselga, J, Mendelsohn, J. The epidermal growth factor receptor as a target for therapy in breast carcinoma. Breast Cancer Res Treat 1994;29:127-138.

3. Tang P, Steck PA, Yung WKA. The autocrine loop of TGF- $\alpha /$ EGFR and brain tumors. J Neuro-Oncol 1997;35:303-314.

4. Schmidt-Ullrich RK, Dent P, Grant S, Mikkelsen RB, Valerie K. Signal transduction and cellular radiation responses. Radiat Res 2000;153:245-257.

5. Moscatello DK, Holgado-Madruga M, Godwin AK, Ramirez G, Gunn G, Zoltick PW, Biegel JA, Hayes RL, Wong AJ. Frequent expression of a mutant epidermal growth factor receptor in multiple human tumors. Cancer Res 1995;55:5536-9.

6. Moscatello DK, Montgomery RB, Sundareshan P, McDanel H, Wong MY, Wong AJ. Transformational and altered signal transduction by a naturally occurring mutant EGF receptor. Oncogene 1996;13:85-96.

7. Frederick L, Wang XY, Eley G, James CD. Diversity and frequency of epidermal growth factor receptor mutations in human glioblastomas. Cancer Res 2000; 60:1383-7.

8. Huang, HS, Nagane M, Klingbeil CK, Lin H, Nishikawa R, Ji XD, Huang CM, Gill GL, Wiley HS, Cavenee WK. The enhanced tumorigenic activity of a mutant epidemal growth factor receptor common in human cancers is mediated by threshold levels of constitutive tyrosine phosphorylation and unattenuated signalling. J Biol Chem 1997;272:2927-35.

9. Nagane M, Coufal F, Lin H, Bogler O, Cavenee WK, Huang HJ. A common mutant epidermal growth factor receptor confers enhanced tumorigenicity on human glioblastoma cells by increasing proliferation and reducing apoptosis. Cancer Res 1996;56:5079-86.

10. Nishikawa R, Ji XD, Harmon RC, Lazar CS, Gill GN, Cavenee WK, Huang HJ. A mutant epidermal growth factor receptor common in human glioma confers enhanced tumorigenicity. Proc Natl Acad Sci U S A 1994;91:7727-31.

11. Wong AJ, Ruppert JM, Bigner SH, Grzeschik CH, Humphrey PA, Bigner DS, Vogelstein B. Structural alterations of the epidermal growth factor receptor gene in human gliomas. Proc Natl Acad Sci U S A 1992;89:2965-9

12. Schmidt-Ullrich RK, Valerie K, Fogleman PB, Walters J. Radiation-induced auto-phosphorylation of epidermal growth factor receptor in human malignant mammary and squamous epithelial cells. Radiat Res 1996;145:79-83.

13. Contessa JN, Reardon DB, Todd D, Dent P, Mikkelsen RB, Valerie K, Bowers GD, Schmidt-Ullrich RK. The inducible expression of dominant negative epidermal growth factor receptor CD533 results in radiosensitization of human mammary carcinoma cells. Clin Cancer Res 1999;5:405-411.

14. Schmidt-Ullrich, R.K.; Valerie, K., Chan, W., McWilliams, D. Altered expression of epidermal growth factor receptor and estrogen receptor in MCF-7 cells after single and repeated radiation exposures. Int J Radiat Oncol Biol Phys 1994, 29, 813-819.

15. Goldkorn T, Balaban N, Shannon M, Matsukuma K. EGF receptor phosphorylation is affected by ionizing radiation. Biochim Biophys Acta 1997;1358:289-99.

16. Kavanagh BD, Lin PS, Chen P, Schmidt-Ullrich RK. Radiation-induced enhanced proliferation of human squamous cancer cells in vitro: A release from inhibition by epidermal growth factor. Clin Cancer Res 1995; 1:1557-1562.

17. Carter S, Auer KL, Reardon DB, Birrer M, Fisher PB, Valerie K, Schmidt-Ullrich RK, Mikkelsen R, Dent $P$. Inhibition of the mitogen activated protein (MAP) kinase cascade potentiates cell killing by low dose ionizing radiation in A431 human squamous carcinoma cells. Oncogene 1998;16:2787-2796.

18. Reardon DR, Contessa JN, Mikkelsen RB, Valerie K, Amir C, Dent P, Schmidt-Ullrich RK. Dominant negative EGFR-CD533 and inhibition of MAPK modify JNK1 activation and enhance radiation toxicity of human mammary carcinoma cells. Oncogene 1999;18:4756-4766.

19. Withers HR, Taylor JMG, Maciejewiski B. The hazard of accelerated tumor clonogen repopulation during radiotherapy. Acta Oncol 1988;27:131-146.

20. Fowler JF. Rapid repopulation in radiotherapy; a debate on mechanism. The phantom of tumor treatment - continually rapid proliferation unmasked. Radiother Oncl 1991;22:156-8. 
21. Schmidt-Ullrich RK, Mikkelsen RB, Dent P, Todd DG, Valerie K, Kavanagh BD et al. Radiationinduced proliferation of the human A431 squamous carcinoma cells is dependent on EGFR tyrosine phosphorylation. Oncogene 1997;15:1191-1197.

22. Contessa JN, Hampton J, Lammering G, Mikkelsen RB, Dent P, Valerie K, and Schmidt-Ullrich RK. Ionizing Radiation Activates Erb-B Receptor Dependent Akt and p70 S6 Kinase Signaling in Carcinoma Cells. Oncogene 2002;21:4032-41.

23. Amorino GP, Mikkelsem RB, Valerie K, Schmidt-Ullrich RK. Dominant-negative cAMP-responsive element- binding protein inhibits proliferating cell nuclear antigen and DNA repair, leading to increased cellular radiosensitivity. J Biol Chem 2003; 278:29394-9.

24 Amorino GP, Hamilton VM; Valerie K; Dent, P; Lammering G; Schmidt-Ullrich RK. Epidermal growth factor receptor dependence of radiation-induced transcription factor activation in human breast carcinoma cells. Mol Biol Cell 2002;13:2233-44.

25. Mendelsohn J. Epidermal growth factor receptor inhibition by a monoclonal antibody as anticancer therapy. Clin Cancer Res, 1997;3:2703-7.

26. Goldstein NI; Prewett M; Zuklys K; Rockwell P; Mendelsohn J. Biological efficacy of a chimeric antibody to the epidermal growth factor receptor in a human tumor xenograft model. Clin Cancer Res 1995;1:1311-8.

27. Bos M, Mendelsohn J; Bowden C. Proc Am Soc Clin Oncol 1996;15:A1381.

28. Sampson JH, Crotty LE; Lee S; Archer GE; Ashley DM; Wikstrand CJ; Hale LP; Small C; Dranhoff G; Friedman AH; Friedmann HS; Bigner DD. Proc Natl Acad Sci USA 2000;97:7503-8.

29. Milas, L.; Mason, K.; Hunter, N. Peterson, S.; Yamakawa, M.; Ang, K.K.; Mendelsohn, J.; Fan, Z. In vivo enhancement of tumor radioresponse by $\mathrm{C} 225$ antiepidermal growth factor receptor antibody. Clin. Cancer Res., 2000, 6, 701-08.

30. Huang SM; Harari PM. Epidermal growth factor receptor blockade with C225 modulates proliferation, apoptosis, and radiosensitivity in squamous cell carcinomas of the head and neck. Cancer Res 1999;59:1935-40.

31. Huang, S.M.; Harari, P.M. Modulation of radiation response after epidermal growth factor receptor blockade in squamous cell carcinomas: inhibition of damage repair, cell cycle kinetics, and tumor angiogenesis. Clin. Cancer Res., 2000, 6, 2166-74.

32. Raben, D.; Buchsbaum, D.J.; Gillespie, Y. Proc. Am. Assoc. Cancer, 1999, 40, A1224.

33. Saleh, M.N.; Raisch, K.P.; Stackhouse, M.A. Combined modality therapy of A431 human epidermoid cancer using anti-EGFr antibody C225 and radiation. Cancer Biother. Radiopharm. 1999, 14, 451-463.

34. Bianco, C.; Bianco, R.; Tortora, G.; Damiano, V.; Guerrieri, P.; Montemaggi, P.; Mendelsohn, J.; De Placido S.; Bianco, A.R.; Ciardiello, F. Antitumor activity of combined treatment of human cancer cells with ionizing radiation and anti-epidermal growth factor receptor monoclonal antibody $\mathrm{C} 225$ plus type I protein kinase A antisense oligonucleotide. Clin. Cancer Res., 2000, 6, 4343-50.

35. Harari P.M.; Huang, S.-M. Radiation response modification following molecular inhibition of epidermal growth factor receptor signaling.Semin. Radiat. Oncol., 2001, 11, $281-289$.

36. Harari P.M.; Huang, S.-M. Epidermal growth factor receptor modulation of radiation response: preclinical and clinical development.Semin. Radiat. Oncol., 2002, 12, 21-26.

37. Bandyopadhyay, D.; Mandal, M.; Adam, L.; Mendelsohn, J.; Kumar, R. Physical interaction between epidermal growth factor receptor and DNA-dependent protein kinase in mammalian cells. J. Biol. Chem., 1998, 273, 1568-73.

38. Perrotte, P.; Matsumoto, T.; Inoue, K.; Kuniyasu, H.; Eve, B.Y.; Hicklin, D.J.; Radinsky, R.; Dinney, C.P. Anti-epidermal growth factor receptor antibody $\mathrm{C} 225$ inhibits angiogenesis in human transitional cell carcinoma growing orthotopically in nude mice.Clin. Cancer Res., 1999, 5, 257-65.

39. Bonner JA, Harari PM, Giralt J, Azarnia N, Cohen RB, Kies MS, Baselga J, Ang KK. Cetuximab prolong survival in patients with locoregionally advanced squamous cell carcinoma of head and neck: a phase III study of high dose radiation therapy with or without cetuximab. Proc Am Soc Clin Oncol 2004, abstr 5507.

40. Fry, D.W.; Kraker, A.J.; McMichael, A.; Ambroso, L.A.; Nelson, J.M.; Leopold, W.R.; Connors, R.W.; Bridges, A.J. A specific inhibitor of the epidermal growth factor receptor tyrosine kinase.Science, 1994, 265, 1093-5.

41. Woodburn, J.R. The epidermal growth factor receptor and its inhibition in cancer therapy. Pharmacol. Ther., 1999, 82, 241-50. 
42. Huang, S.M.; Li, J.; Armstrong, E.A.; Harari, P.M. Modulation of radiation response and tumorinduced angiogenesis after epidermal growth factor receptor inhibition by ZD1839 (Iressa). Cancer Res., 2002, 62, 4300-4306.

43. Raben, D.; Helfrich, D.; Chan, D.; Shogun, T.; Zundel, W.; Scafani, R.; Bunn, P.J. ZD1839, a selective epidermal growth factor receptor tyrosine kinase inhibitor, alone and in combination with radiation and chemotherapy as a new therapeutic strategy in non-small cell lung cancer.Clin. Cancer Res., 2001, 7, 3805 s.

44. Rao, G.S.; Murray, S.; Ethier, S.P. Radiosensitization of human breast cancer cells by a novel ErbB family receptor tyrosine kinase inhibitor.Int. J. Radiat. Oncol. Biol. Phys., 2000, 48, 1519-28.

45. Williams, K.J.; Telfer, B.A.; Stratford, I.J.; Wedge, S. ZD1839 ('Iressa'), a specific oral epidermal growth factor receptor-tyrosine kinase inhibitor, potentiates radiotherapy in a human colorectal cancer xenograft model. Br J Cancer. 2002 , 86:1157-61.

46. Raben, D.; Phistry, M.; Helfrich, B. Gastrointestinal Cancer Research Conference, 2000, Orlando, Florida.

47. Stea B, Falsey R, Kislin K, Patel J, Glanzberg H, Carey S, Ambrad AA, Meuillet EJ, Martinez JD. Time and dose-dependent radiosensitization of the glioblastoma multiforme U251 cells by the EGF receptor tyrosine kinase inhibitor ZD1839 ('Iressa'). Cancer Lett. 2003; 202:43-51.

48. Solomon B, Hagekyriakou J, Trivett MK, Stacker SA, McArthur GA, Cullinane C. EGFR blockade with ZD1839 ("Iressa") potentiates the antitumor effects of single and multiple fractions of ionizing radiation in human A431 squamous cell carcinoma. Int J Radiat Oncol Biol Phys. 2003 Mar $1 ; 55(3): 713-23$.

49. Baumann M, Krause M, Zips D, Eicheler W, Doerfler A, Ahrens J, Petersen C, Bruechner K, Hilberg F. Selective inhibition of the epidermal growth factor receptor tyrosine kinase by BIBX1382BS and the improvement of growth delay, but not local control, after fractionated irradiation in human $\mathrm{FaDu}$ squamous cell carcinoma in the nude mouse. Int J Radiat Biol 2003;79:547-559.

50. Toulany M, Dittmann K, Baumann M, Rodemann HP. Role of EGF receptor ligands as molecular targets in K-Ras mutated human tumor cells. Proc Int Wolfsberg Meeting 2004;8:PIV2.

51. Wikstrand, C.J.; McLendon, R.E.; Friedman, A.H.; Bigner, A.D. Cell surface localization and density of the tumor-associated variant of the epidermal growth factor receptor, EGFRvIII. Cancer Res., 1997, $57,4130-4140$.

52. Giaccone G, Herbst RS, Manegold C, Scagliotti G, Rosell R, Miller V, Natale RB, Schiller JH, Von Pawel J, Pluzanska A, Gatzemeier U, Grous J, Ochs JS, Averbuch SD, Wolf MK, Rennie P, Fandi A, Johnson DH. Gefitinib in combination with gemicitabine and cisplatin in advanced non-small-cell lung cancer: a phase III trial - INTACT 2. J Clin Oncol 2004;22:777-84.

53. Herbst RS, Giaccone G, Schiller JH, Natale RB, Miller V, Manegold C, Scagliotti G, Rosell R, Oliff I, Reeves JA, Wolf MK, Krebs AD, Averbuch SD, Ochs JS, Grous J, Fandi A, Johnson DH. Gefitinib in combination with paclitaxel and carboplatin in advanced non-small-cell lung cancer: a phase III trial INTACT 2. J Clin Oncol 2004;22:785-94.

54. Kris MG, Natale RB, Herbst RS, Lynch TJ Jr, Prager D, Belani CP, Schiller JH, Kelly K, Spiridonidis $\mathrm{H}$, Sandler A, Albain KS, Cella D, Wolf MK, Averbuch SD, Ochs JJ, Kay Ace . Efficiacy of gefinitib, an inhibitor of the epidermaL growth factor receptor tyrosine kinase, in symptomatic patients with non-small cell lung cancer: a randomized trial. JAMA 2003;290:2149-58.

55. Fukuoka M, Yano S, Giaccone G, Tamura T, Nakagawa K, Douillard JY, Nishiwaki Y, Vansteenkiste J, Kudoh S, Rischin D, Eek R, Horai T, Noda K, Takata I, Smit E, Averbuch S, Macleod A, Feyereislova A, Dong RP, Baselga J. Multi-institutional randomised phase II trial of gefitinib for previously treated patients with advanced non-small-cell-lung cancer. J Clin Oncol 2003;21:2237-46.

56. Lynch TJ, Bell DW, Sordella R, Gurubhagavatula S, Okimoto RA, Brannigan BW, Harris PL, Haserlat SM, Supko JG, Haluska FG, Louis DN, Christiani DC, Settleman J, Haber DA. Activating mutations in the epidermal growth factor receptor underlying responsiveness of non-small-cell-lung cancer to gefinitinib. N Engl J Med 2004;350:2129-38. 


\section{Chapter VI}

Samenvatting

Curriculum Vitae

Lijst van publicaties 


\section{IV.1. Samenvatting}

(References are listed in Chapter V.4)

De epidermale groeifactor receptor (EGFR) en andere ErbB receptor-tyrosine kinasen spelen een belangrijke rol in de neoplastische groeicontrole van veel carcinoom- en glioomcellen (1-4). Dit is het gevolg van de ongecontroleerde activering van receptor-tyrosine kinasen met daaraan gekoppelde secundaire stimulatie van downstream signaal transductie cascade (4). Zoals het geval is met andere groeifactorreceptoren, kan toename van EGFR-expressie het gevolg zijn van amplificatie (genvermeerdering), toename van transcriptie, mRNA-translatie of mutatie. Dit heeft een ongereguleerd toegenomen receptorsignaal tot gevolg. Voor veel carcinomen en gliomen is een toegenomen EGFR-activiteit gecorreleerd aan tumorgroei en kwaadaardige progressie $(5,6)$. De overexpressie van EGFR in autocriene groei gereguleerde carcinoom- and glioomcellen is onderdeel van de neoplastische progressie en is frequent geassocieerd met de expressie van mutanten vormen (5,7-10). De meest frequente EGFR-mutatie is een variant, EGFRvIII genaamd, welke het resultaat is van het wegvallen van exonen 2-7 van het EGFR-gen (8). Deze mutatie resulteert in een receptor met een constitutief actieve tyrosine kinase, welke ligand-onafhankelijk celtransformatie kan induceren $(6,11)$. EGFRvIII is alleen aanwezig op het celoppervlak van tumoren, niet in normale weefsels $(5,7)$. Een andere waarneming is dat deze receptor alleen in vivo op tumorcellen tot expressie komt en snel verdwijnt in tumorcellen in kweek. Om deze reden zijn studies naar de werking en unieke functies van EGFRvIII tot op heden slechts beperkt uitgevoerd.

Eerder uitgevoerd onderzoek heeft aangetoond dat bestraling van tumorcellen kan resulteren in een directe activering van de ErbB-receptor familie en dat herhaaldelijke blootstelling aan een bestraling van 2 Gy kan leiden tot een toegenomen expressie van EFGR (12-14). Deze door straling geïnduceerde activering van EGFR wordt gekenmerkt door een veelvuldige toename van de tyrosine fosforylatie met een secundaire activering van bestaande 'signaal transductie cascades' van MAPK en PI-3-K (12, 15-17). De door straling geïnduceerde activering van de EGFRreceptorfamilie leidt tot een dosisafhankelijke proliferatieve respons, welke gemeten kan worden na zowel eenmalige als herhaaldelijke blootstelling aan straling $(13,16,18)$. Hieruit is afgeleid dat de door straling geïnduceerde activering van EGFR betrokken is bij (het mechanisme van) versnelde proliferatie of hernieuwde populatie van kanker cellen. Deze cellulaire proliferatieve respons na herhaaldelijke blootstelling aan straling leidt tot een toename van unieke tumor klonen. $(19,20)$. Gezien de toegenomen biosynthetische activiteit van snel prolifererende tumorcellen, zal dit waarschijnlijk gepaard gaan met een verhoogde reparatie van DNA-schade. 
Zowel de stralinggeïnduceerde proliferatieve reactie als de verbeterde DNA reparatiemogelijkheid van tumorcellen verminderen de toxische effecten van radiotherapie. Om deze reden wordt het EGFR-geïnduceerde effect op tumorcellen als celbeschermend (cytoprotectieve respons) gezien. Gegeven de speciale rol van de EGFR-familie in het initiëren van deze cytoprotectieve respons na bestraling, zou verstoring van de ErbB-receptorfunctie de cytoprotectieve respons moeten voorkomen and daardoor de gevoeligheid voor bestraling van de tumorcel kunnen verhogen.

Het promotieonderzoek wat hier beschreven wordt is gebaseerd op de hypothese dat het voorkomen van door straling geïnduceerde activering van de EGFR-response, de gevoeligheid voor bestraling van de tumorcellen kan verbeteren, onafhankelijke van variërende ErbB-expressieprofielen. Om de functie van de EGFR-receptorfamilie effectief te blokkeren hebben we een genetische benadering van adenovirale overexpressie van een dominant-negatieve EGFR toegepast, EGFR-CD533 genaamd (Figure 1.1.5). EGFR-CD533 heeft als voordeel dat het niet alleen de functie van EGFR zelf onderdrukt, maar ook de functie van het gehele ErbB-receptor-tyrosine kinase netwerk alsmede de functie van het natuurlijk voorkomende mutanten EGFR soorten.

Ten eerste was het belangrijk om te bepalen in welke mate de ErbB 1-4 receptor tyrosine kinasen een rol spelen in de stralings geïnduceerde signaal transductie van menselijke tumorcellen. Voorheen werd aangenomen dat de gevolgen downstream van de door straling geïnduceerde activering van de ErbB receptoren niet te onderscheiden waren van activering door groeifactoren. Om de mogelijke verschillende downstream-effecten door groeifactoren en straling te identificeren hebben we de effecten in verschillende kankercellijnen uit de borstklier vergeleken, welke verschilden in hun ErbB-expressieprofielen. Een belangrijke vinding was dat we konden aantonen dat in tegenstelling tot behandeling van cellen met groeifactor ErbB1 of ErbB4, welke resulteerde in hiërarchische transactivering van ErbB2 en ErbB3, bestraling zonder onderscheid alle ErbB soorten met een activeringsprofiel dat overeenkwam met het ErbB expressieprofiel van de cel, activeerde (Hoofdstuk II.1). Bovendien werd ErbB2 geïdentificeerd als een afgeleide van ErbB1 of ErbB4, hetgeen leidde tot andere downstream MAPK respons profielen na blootstelling aan straling (Hoofdstuk 11.1). Om deze reden lieten onze data voor de eerste keer zien dat ErbB expressieprofielen van menselijke kankercellen de ErbB-receptoractivering kan beïnvloeden als reactie op ioniserende straling. Daarom zouden therapeutische interventies die als doel hebben om humane tumorcellen gevoeliger te maken voor bestraling, de remming van de functie van het gehele ErbB receptor-tyrosine kinase netwerk in acht moeten nemen, zodat de gevoeligheid voor bestraling effectief verhoogd wordt, onafhankelijk van de variërende ErbB-expressieprofielen. Deze vinding moedigde ons aan om verder te gaan met de ontwikkeling van een genetische benadering van de 
remming van het ErbB-receptor tyrosine netwerk door middel van expressie van dominant-negatief EGFR-CD533.

We hebben daarom de mogelijkheid van een gentherapeutische benadering verder onderzocht. We hebben hiervoor gebruik gemaakt van een adenovirus dat zich niet kan vermeerderen voor de overdracht van EGFR-CD533, met als doel de gevoeligheid voor bestraling te verhogen. In het onderzoek werd de directe stralengevoeligheid in vitro gemeten voor een breed spectrum van verschillende tumorcellijnen met variërende expressieprofielen voor de ErbB-receptoren (Hoofdstuk 1I.2). Nadat we alle geteste cellijnen hadden gekarakteriseerd op de verschillen in ErbBreceptorexpressieprofielen en de experimentele condities hadden geoptimaliseerd voor de adenovirale genoverdracht van EGFR-CD533, lieten onze experimenten complete remming van stralinggeïnduceerde activering van EGFR zien na EGFR-CD533 expressie. Klonogene overleving analyses koppelden de expressie van EGFR-CD533 aan een significante toename van de intrinsieke stralengevoeligheid van alle geteste cellijnen, na zowel een enkele als herhaaldelijke blootstellingexperimenten (Hoofdstuk II.2; Hoofdstuk III.2). We kunnen daarom concluderen dat onze gegevens bewijs leveren voor de constatering dat alle cellijnen die getest werden effectief een transductie kunnen ondergaan, zodat ze EGFR-CD533 tot expressie kunnen brengen, gebruik makend van een gentherapeutische benadering door Ad-EGFR-CD533 te gebruiken, en dat de geteste cellijnen effectief gevoeliger werden gemakt voor ioniserende straling.

Voornoemde resultaten brachten ons ertoe om de gentherapeutische benadering in vivo verder te testen in getransplanteerde tumoren. We hebben daarvoor de adenovirale vector met EGFR-CD533 ingebracht in de (te transplanteren) tumorcellen in naakte muizen en vervolgens bepaald of het percentage met recombinant adenovirus geïnfecteerde tumorcellen de tumorrespons op ioniserende straling kon beïnvloeden. Verder hebben we de data uit in vivo en in vitro experimenten gekoppeld om te onderzoeken of het mechanisme wat de toename van de gevoeligheid voor bestraling in vitro bepaalde hetzelfde was als het mechanisme wat in vivo in werking werd gesteld. Om de gevoeligheid van U-87 MG cellen en MDA-MB-231 cellen voor transductie met adenovirus te bepalen, hebben we eerst de optimale transductie condities vastgesteld door gebruik van het AdLacZ reporter virus, waarbij een respectievelijk $59-65 \%$ en $44 \%$ transductie efficiency werden bereikt (Hoofdstuk III). Onder deze condities resulteerde intra-tumorale toevoeging van Ad-EGFRCD533 in een significante hogere gevoeligheid voor bestraling, resulterend in een dosis versterkende factor (dose-enhancement ratio) van respectievelijk 1.8 en 1.85 na drie herhaalde blootstellingen aan bestraling van 3 en 1.5 Gy voor U-87MG en MDA-MB-231 tumoren. Dit was vergelijkbaar met de mate van verhoging van stralengevoeligheid verkregen met cellen van MDA- 
EGFR-CD533 tumoren, waarin alle cellen bewerkt zijn om stabiel EGFR-CD533 tot overexpressie te brengen (Hoofdstuk III.3). Deze gegevens tonen aan dat een gentherapeutische benadering waarbij een dominant-negatief EGFR-CD533 tot overexpressie wordt gebracht door in vivo gebruik te maken van overdracht door een adenovirale vector, effectief de stralengevoeligheid van xenograft tumoren kan verhogen na herhaalde blootstelling aan bestraling. Het mechanisme wat de stralengevoeligheid verhoogt is hetzelfde in xenograft tumoren als in gekweekte cellen, wat de therapeutische mogelijkheden van deze benadering bevestigt (Hoofdstuk III.3).

Een ander belangrijk aspect van dit promotieonderzoek betreft onderzoek naar de overdrachtseffecten van EGFRvIll op acute cellulaire reacties op bestraling and mogelijke invloeden op de tumorceloverleving na bestaling. Omdat EGFRvill niet tot expressie wordt gebracht in gekweekte cellen hebben we eerst een studie naar de werking gedaan in CHO (Chinese hamster ovarii) cellen die kortstondig getransfecteerd waren met EGFRvIII cDNA (Hoofdstuk IV.1). Zoals verwacht, activeerde EGF wel EGFRwt, maar niet EGFRvIII. Een enkele blootstelling aan straling van 2 Gy daarentegen resulteerde in een onmiddellijke 4.3-voud toename van Tyr (tyrosine) fosforylatie, welke onmiddellijk een secundaire downstream toename in MAPK en Aktactiviteit induceerde, waarbij de toename door stralinggeïnduceerde EGFRwt activering ruim werd overschreden (Hoofdstuk IV.1). Stralinggeïnduceerde activering van EGFRvIII resulteerde dus in een effectieve verandering in de CHO-cel gevoeligheid voor bestraling (Hoofdstuk IV.1). Op deze wijze werd EGFRvIII als een ander belangrijk therapeutisch doelwit geïdentificeerd om ons op te richten voor het verhogen van de stralengevoeligheid van tumorcellen.

Om vervolgens onderzoek naar de functie van EGFRvIII in vitro in humane maligne glioomcellen mogelijk te maken, daarbij rekening houdend met de frequente expressie van EGFRvIII in maligne glioomtumoren, hebben we een adenovirale vector ontwikkelt om EGFRvill tot overexpressie te brengen in gekweekte cellen in vitro. Verder hebben we de EGFRvIII-functie onderzocht tijdens intrinsieke expressie in xenograft tumoren en bovendien hebben we het mogelijk gebruik van AdEGFR-CD533 om de EGFRvIII-functie in vivo en in vitro te remmen onderzocht. Ons onderzoek toonde aan dat ioniserende straling in een significante activering van EGFRvIII in vivo resulteert, hetgeen een krachtiger cytoprotectieve respons in tumoren tot stand brengt dan voorheen gedemonstreerd voor EGFRwt (Hoofdstuk IV.2). Bovendien werd aangetoond dat EGFR-CD533 ook als een mogelijke remmer van de EGFRvIII-functie optreedt, daarbij de gezelverwekkende capaciteit en de relatieve stralengevoeligheid veroorzaakt door EGFRvIII tenietdoend (Hoofdstuk IV.2). 
Samenvattend hebben we voor de eerste keer aangetoond dat functionele remming van de ErbBreceptor tyrosine kinasen door dominant-negatief EGFR-CD533 tot een significant hogere gevoeligheid voor bestraling leidt voor een breed spectrum van verschillende tumorcellen, onafhankelijk van de variërende niveaus van de ErbB-receptor. Het mechanisme wat de hogere stralengevoeligheid verklaart heeft betrekking op de vernietiging van de belangrijke ErbB-receptor afhankelijke stralinggeïnduceerde pro-proliveratieve en cytoprotectieve reactie, welke normaal gesproken de toxische effecten van bestraling zou tegenwerken door een betere capaciteit om DNAschade te repareren, welke veroorzaakt wordt door een toegenomen biosynthetische activiteit (Hoofdstuk II). Daarom toonde de verder ontwikkelde gentherapeutische benadering van de intratumorale toediening van Ad-EFGR-CD533 in humane tumoren en maligne glioom xenograften een dominant-negatief EGFR fenotype en werd de gevoeligheid voor bestraling van tumoren volgens hetzelfde mechanisme als in gekweekte cellen effectief verhoogd (Hoofdstuk III). Overexpressie van EGFR-CD533 kan dus een belangrijke mogelijkheid bieden voor verbetering van de gevoeligheid van tumorcellen voor ioniserende stralen.

Bovendien heeft ons onderzoek de frequent in veel verschillende tumoren natuurlijk voorkomende variant van EGFR, EGFRvIII, geïdentificeerd als belangrijke overbrenger van stralengevoeligheid van tumorcellen. Dit kan worden verklaard door een sterke stralengeïnduceerde activering van EGFRvIII, resulterend in een meer intensieve downstream activering van pro-proliveratieve and antiapoptose MAPK and PI3K signaal cascades, welke leidt tot een sterkere celbeschermende reactie op bestraling, dan voorheen bekend was voor EGFRwt. Een belangrijke conclusie uit ons onderzoek is ook dat expressie van EGFR-CD533 effectief de EGFRvIII-functie remt, daarbij de brede mogelijkheden om EGFR-CD533 te gebruiken om humane tumoren gevoeliger te maken voor bestraling bevestigend (Hoofdstuk IV).

Onze gegevens bevestigen dat genetische remming van stralinggeïnduceerde activering van de ErbB-receptor tyrosine kinasen als ook van de variant EGFRvIII door de dominant-negatieve EGFR-CD533 een effectieve en breed toepasbare nieuwe therapeutische interventie voor verhoogde stralengevoeligheid van tumorcellen biedt. Dit zou verder ontwikkeld moeten worden als een veelbelovende gentherapeutische innovatie voor de behandeling van kanker door verhogen van de stralengevoeligheid van tumorcellen. 


\section{VI.2. Curriculum Vitae}

Date and Place of Birth:

Office Address:

\section{Education:}

School:

Universities:

Doctor of Medicine (Germany):

Medical License:

Board Certification:
May 20, 1969 Nordhorn, Niedersachsen, Germany

Department of Radiation Oncology, MaastRO Clinic, University of Maastricht, The Netherlands

Henri Dunantstraat 5, Postbus 4446, 6401 CX Heerlen

0031-(0)45-5771200 (office), 0031-(0)45-5740277 (fax)

E-mail: guido.lammering@maastro.nl

1979-88 Private senior high school (Missionsgymnasium St. Antonius, Bardel), Bad Bentheim, Germany; Degree: Abitur.

1989-95 University of Duesseldorf, School of Medicine, Germany; premedical, preclinical and clinical subjects; Degrees: 1991 Physicum; Boards in Medicine (1.,2. Staatsexamen) 1992,1995. 1995-96 University of Muenster School of Medicine, Germany. Clinical subjects. Final Board in Medicine (3. Staatsexamen) 1996 magna cum laude

1997 (Thesis); magna cum laude; title: Alteration of DNA Ploidy and Cell Proliferation induced by Preoperative Radiotherapy as a Prognostic Factor in Rectal Cancer; Departments of Radiation Oncology and Gastroenterology, University of Duesseldorf, Germany

1997; Germany and European Community

2002; Radiation Oncology, Germany and European Community

\section{Vocational Training:}

1996

1995

1992-93

1990
Internship:Radiology and Oncology, St. Josefs Hospital, Paderborn Internship: Surgery, University of Bern School of Medicine, Bern Assistant Teacher: Pathology, Dept. of Pathology, Duesseldorf Assistant Teacher: Anatomy, Dept. of Anatomy, Duesseldorf

\section{Clinical Practice and Research Training:}

2003-

2003

2001-2002

$1999-2001 / 2002$

$1997-1999$

1996-1997
Staff Radiation Oncologist, Dept. of Radiation Oncology, MaastRO Clinic, University of Maastricht, The Netherlands

Staff Radiation Oncologist, Dept. of Radiation Oncology, University of Duesseldorf

Resident, Radiation Oncology, University of Duesseldorf

Research Scholarship and Clinical Training Dept. of Radiation Oncology, Medical College of Virginia, Virginia Commonwealth University, Richmond, VA, USA

Resident, Radiation Oncology, University of Duesseldorf

Resident, Radiology and Hematology/Oncology, St. Josef s Hospital, Paderborn, Germany

1996-1999
Research fellow in molecular biology (Dr. R. Porschen's Lab), Duesseldorf, Germany 


\section{Teaching:}

2002 - present

Medical Students; Radiobiology; Combination of Radiation and Chemotherapy, University of Duesseldorf

2001 - present

Residents in Radiation Oncology

$1997-1999$

Nurse Students; Internal Medicine, Radiology and Anatomy

$2001-2003$

Radiation Therapist Students; Radiology and Radiation Oncology

\section{Other Professional Activities:}

Special training in Radiology; Ultrasound, CT/MRI Scan

Special training in Emergency Medicine

\section{Memberships and Assignments in Medical/ Scientific Societies:}

Associate Member of the American Association of Cancer Research (AACR)

German Society for Radiation Oncology (DEGRO)

European Society for Therapeutic Radiology and Oncology (ESTRO)

"Translational Research Group" of the European Organization for Research and Treatment of Cancer (EORTC) - Radiotherapy Group; member in the subgroup „Signal Tranduction; Innovative Treatment - Biological Modifiers".

2002 - present

2002 - present

\section{Honors and Awards:}

1997

$1999-2001$

2001

2001

\section{Research Grants:}

Ad hoc Reviewer International Journal of Radiation Biology

Ad hoc Reviewer International Journal of Rad. Oncol. Biol Phys.

1999-2001: 120.000 Euro; Mildred Scheel Stiftung; project: modulation of tumor cell radiosensitivity through adenoviral overexpression of dominant- negative EGFR

\section{References:}

Prof. Dr. P. Lambin, M.D., Ph.D., Chairman, Dept. of Radiation Oncology, University of Maastricht, MaastRO Clinic, Maastricht

Prof. R. Schmidt-Ulirich, M.D., Chairman, Dept. of Radiation Oncology, Medical College of Virginia, Richmond, VA, USA

Prof. Dr. G. Schmitt, Chairman, Dept. of Radiation Oncology, University of Duesseldorf, Germany

Prof. K. Valerie, Ph.D., Director, Molecular Biology Section, Dept. of Radiation Oncology, Medical College of Virginia, Richmond, VA, USA

Prof. Dr. R. Porschen, Chairman, Dept. of Internal Medicine, Central Hospital East, Bremen, Germany 


\section{VI.3. Lijst van publicaties}

(Impact Factor $=\mathrm{IF} ; 2002)$

G Lammering, K Valerie, PS Lin, TH Hewit, RK Schmidt-Ullrich. Radiation- induced activation of a common variant of EGFR confers enhanced radioresistance. Radiother Oncol 2004, in press (2.82)

G Lammering, TH Hewit, K Valerie, W Hawkins, PS Lin, RB Mikkelsen, RK Schmidt-Ullrich. Inhibition of the EGFRvIII mutant receptor by dominant-negative EGFR-CD533 enhances malignant glioma cell radiosensitivity. Clin. Cancer Res 2004, in press (5.07)

MM Taher, G Lammering, C Hershey. Curcumin Inhibits Ultraviolet Light Induced Human Immunodeficiency Virus Gene Expression. Mol Cell Biochem. 2003, 254:289-97 (1.50)

Schmidt-Ullrich RK, Contessa JN, Lammering G, and Amorino GP. Receptor tyrosine kinases and cellular responses to ionizing radiation. Oncogene Reviews 2003, 22:5855-65. Review (6.74)

G Lammering, T Hewit, K Valerie, JN Contessa, GP Amorino, P Dent, RK Schmidt-Ullrich. Ligand-independent potential of a mutant EGF receptor to furnish a strong cyto-protective response following ionizing radiation. Oncogene 2003, 22:5545-53. (6.74)

G Lammering. Anti-Epidermal Growth Factor Receptor Strategies to Enhance Radiation Action. Review, Curr Med Chem Anti-Canc Agents. 2003, 3:327-33. (-)

G Lammering, TH Hewit, K Valerie, PS Lin, JN Contessa, RK Schmidt-Ullrich. An anti-erbB receptor strategy as gene therapeutic intervention to improve radiotherapy in malignant human tumours. Int J Rad Biol 2003, 79:561-8 (2.36)

PJ Keall, G Lammering, PS Lin, DS Winter, TD Chung, R Mohan, RK Schmidt-Ullrich. Tumor control probability predictions for genetic radiotherapy. Int J Radiat Oncol Biol Phys 2003, 57:255-63. (3.33)

A Mueller, R Keus, N Neumann, G Lammering, T Schnabel. Management of Merkel cell carcinoma: Case series of 36 patients. Oncology Reports 2003, 10:577-85 (1.22)

MM Taher, G Lammering, CM Hershey, KC Valerie. Mood enhancing antidepressant St. John's wort inhibits the activation of human deficiency virus gene expression by ultraviolet light. IUBMB Life 2002, 54:357-64. (1.08)

Amorino G, Hamilton V, Valerie K, Dent P, Lammering G, Schmidt-Ullrich RK. Epidermal Growth Factor Receptor Dependence of Radiation induced Transcription Factor Activation in Human Breast Carcinoma Cells. Mol Biol Cell 2002, 13:2233-44 (7.70)

Contessa JN, Hampton J, Lammering G, Mikkelsen RB, Dent P, Valerie K, and Schmidt-Ulirich RK.Ionizing Radiation Activates Erb-B Receptor Dependent Akt and p70 S6 Kinase Signaling in Carcinoma Cells. Oncogene, 2002, $21: 4032-41$. (6.74)

G Lammering, R Schmidt-Ullrich, K Valerie, TH Hewit, JN Contessa, PS Lin. Gene therapeutic disruption of ErbB- dependent radiation-induced cytoprotective signaling results in tumor cell radiosensitization. Exp Strahlenther Klin Strahlenbiol 2002, 11:109-112 (-) 
G Lammering, PS Lin, JN Contessa, JL Hampton, K Valerie, RK Schmidt-Ullrich. Adenovirusmediated over-expression of dominant negative epidermal growth factor receptor-CD533 as a gene therapeutic approach radiosensitizes human carcinoma and malignant glioma cells. Int $\mathbf{J}$ Radiat Oncol Biol Phys 2001, 51:775-784. (3.33)

Musch E, Malek M, Lammering G, Linden-Lammering S, Hartlapp JH, Chrissafidou A. Palliation by intratumoral infiltration with natural interferon-beta. Onkologie 2001, 24:362-6. (0.57)

G Lammering, T H Hewit, W Hawkins, JN Contessa, DB Reardon, PS Lin, K Valerie,P Dent, RB Mikkelsen, RK Schmidt-Ullrich. Epidermal growth factor receptor as a genetic therapy target for carcinoma cell radiosensitization. J Natl Cancer Inst 2001, 93:921-9. (14.24)

G Bowers, D Reardon, T Hewit, P Dent, RB Mikkelsen, K Valerie, G Lammering, C Amir, R Schmidt-Ullrich. The relative role of ERBB1-4 receptor kinases in radiation signal transduction responses of human carcinoma cells. Oncogene 2001, 20:1388-97. (6.74)

G Lammering, K Valerie, PS Lin, RB Mikkelsen, JN Contessa, JP Feden, J Farnsworth, P Dent, R Schmidt-Ullrich. Radiosensitization of malignant glioma cells through over-expression of dominant-negative EGFR. Clin Cancer Res 2001, 7:682-90. (5.07)

G Lammering, MM Taher, F Borchard, HH Gruenagel, R Porschen. The prognostic value of Sphase fraction in preoperative radiotherapy of rectal cancer. Oncol Rep 2001, 1:201-6. (1.22)

G Lammering, KA Hartmann, M Frenken, B Aryus, R Döker, B Ulrich. Short-term hypofractionated radiotherapy followed by total mesorectal excision (TME). Strahlenther Onkol 2000, 176:555-559. (3.01)

G Lammering, MM Taher, HH Grünagel, F Borchard, R Porschen. Alteration of DNA ploidy status and cell proliferation induced by preoperative radiotherapy is a prognostic factor in rectal cancer. Clin Cancer Res 2000, 6:3215-21. (5.07)

B Aryus, W Audretsch, F Gogolin, S Gripp, Th Königshausen, G Lammering, R Rohn, G Schmitt, KA Hartmann. Remission rates following preoperative chemotherapy and radiation therapy in patients with breast cancer. Strahlenther Onkol 2000, 176:411-415. (3.01)

KA Hartmann, UM Carl, P Sminia, G Lammering, KA Becker, G Schmitt. The influence of inspiratory hyperoxia on ischemia-reperfusion-induced tumour growth delay. Oncol Rep 2000, 7:131-133. (1.22)

G Lammering, UM Carl, H Pape, KA Hartmann. Changes in haemoglobin level during combined radiochemotherapy in locally advanced head and neck cancer. Strahlenther Onkol 1999, 175:559562. (3.01)

Nehls, B Klump, K Holzmann, G Lammering, F Borchard, HH Gruenagel, V Gaco, M Gregor, R Porschen. Influence of p53 status on prognosis in preoperatively irradiated rectal carcinoma. Cancer 1999, 85:2541-8. (3.91) 


\section{VI.4. Dankwoord/Acknowledgments}

Iedereen die, op welke manier dan ook, heeft bijgedragen aan het tot stand komen van dit proefschrift wil ik hartelijk bedanken.

Allereerst en bovenal gaat mijn dank uit naar Prof. R. Schmidt-Ullrich en Prof. G. Schmitt. Zij hebben mij gedurende mijn gehele opleidingsperiode aangespoord en gesteund bij het verwezenlijken en afronden van mijn wetenschappelijk onderzoek. Prof. Schmidt-Ullrich bood mij de mogelijkheid om onderzoek te doen op de afdeling moleculaire biologie van zijn researchlaboratorium en maakte daarnaast regelmatig klinische bijscholing in de radiologische oncologische kliniek mogelijk. Verder voelde ik mij continu door hem gesteund bij het realiseren van de projecten. Alle experimentele studies tijdens het wetenschappelijk werk in het laboratorium van Prof. Schmidt-Ullrich vormden de juiste basis voor dit proefschrift. Ik kijk met groot genoegen uit naar onze verdere samenwerking de komende jaren. Verder wil ik Prof. G. Schmitt hartelijk bedanken voor zijn ondersteuning bij mijn ontwikkeling tot wetenschapper.

Another big and special thank you goes to my researchteam in Richmond, VA, USA, Theodore Hewit, Joseph N Contessa, George Amorino, William Hawkins und Jamie L Hampton. Without your intensive and great help, this rapid successful production of all the many experimental data within such a short period of time would have never been possible. In addition, I would greatly like to thank the professors Peck-Sun Lin, Kristoffer Valerie, Paul Dent und Ross Mikkelsen, molecular biology section of the Dept. of Radiation Oncology, Medical College of Virginia, VCU, USA, for the many lively discussions, suggestions, helps and fair comments and I am very much looking forward to further fruitful collaborations.

Mijn promotoren Prof. dr. Philippe Lambin en dr. Bradly Wouters wil ik in het bijzonder danken voor hun steun en constructieve kritiek gedurende de voltooiing en de verwezenlijking van de promotie hier in Nederland in Maastricht. Hartelijk dank voor de steun en voor de mij geboden mogelijkheid, mijn onderzoek binnen hun afdeling op het laboratorium ook in de toekomst voort te zetten. Rianne Herben, de secretaresse van Prof. dr. Lambin, wil ik hartelijk bedanken voor de uitgebreide administratieve hulp. Baukje Vrieswijk, Hannie Kleijnen-Maassen, stafmedewerker en Willem Voncken wil ik bedanken voor de uitgebreide vertalingshulp. Anderen die ik hartelijk wil bedanken voor hun medewerking aan het manuscript zijn de ICT medewerkers Stephan Opgenoorth, Rob van der Moolen en Richard Aarts. 
De leden van de beoordelingscommissie, te weten Prof.dr. F. Ramaekers (voorzitter), Prof. dr. M. Baumann, Prof. dr. D. Kieback, Prof. dr. A. van der Kogel, Prof. dr. H. Schouten, wil ik bedanken voor hun tijd en interesse die zij hebben besteed aan het beoordelen van het manuscript.

Al mijn collega's radiotherapeuten in MaastRO Clinic zou ik graag willen danken voor hun steun en consideratie tijdens het tot stand komen van dit proefschrift. Ook mijn paranimfen, Roland Chiu en Baukje Vrieswijk wil ik speciaal bedanken voor alle praktische ondersteuning.

In het bijzonder wil ik mijn ouders bedanken. Jullie waren er altijd op de achtergrond, waarbij jullie me steunden en stimuleerden in alles wat ik deed. Bedankt voor jullie vertrouwen.

Tobias en David, dit is het proefschrift. Hoewel ik vaak probeerde tijd voor jullie vrij te maken schoot het er toch vaak bij in. Jullie zijn onmisbaar voor mijn kwaliteit van leven.

Lieve Judith, mijn dierbaarste, mijn grote liefde en trots, jou wil ik het meest van allemaal bedanken. Alleen jij weet echt hoeveel tijd dit onderzoek ons heeft gekost. Ondanks dat ik beijna 2,5 jaar in Amerika ben geweest, ben je me blijven steunen. Ik heb veel respect voor de manier waarop jij de zaken in ons zich uitbreidende gezin steeds weet te regelen, temeer daar ik nogal eens bezig ben met onderzoek. Dank voor je geduld en onvoorwaardelijke steun en dat je me zo gelukkig makkt. 